
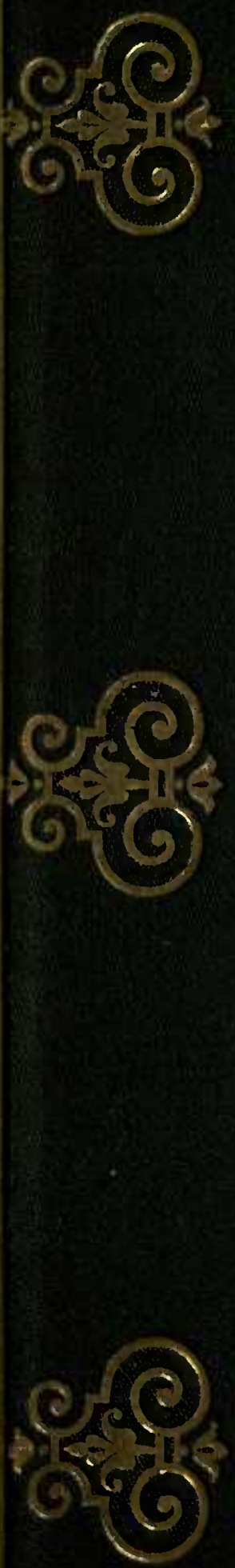

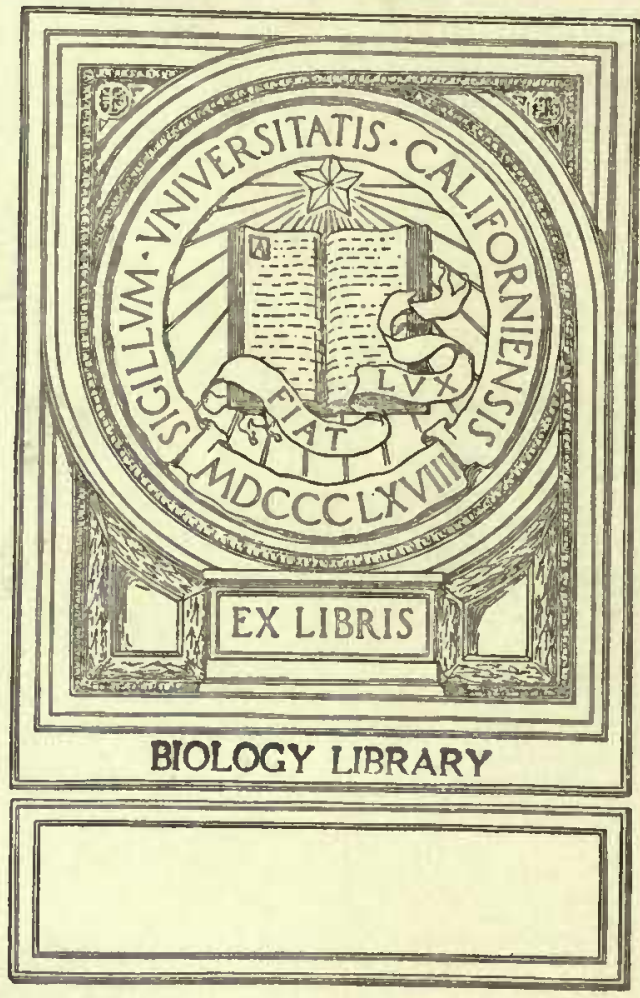

NATURAL HISTORY

Axt,

ANTIQUITIES OF SELBORNE. 








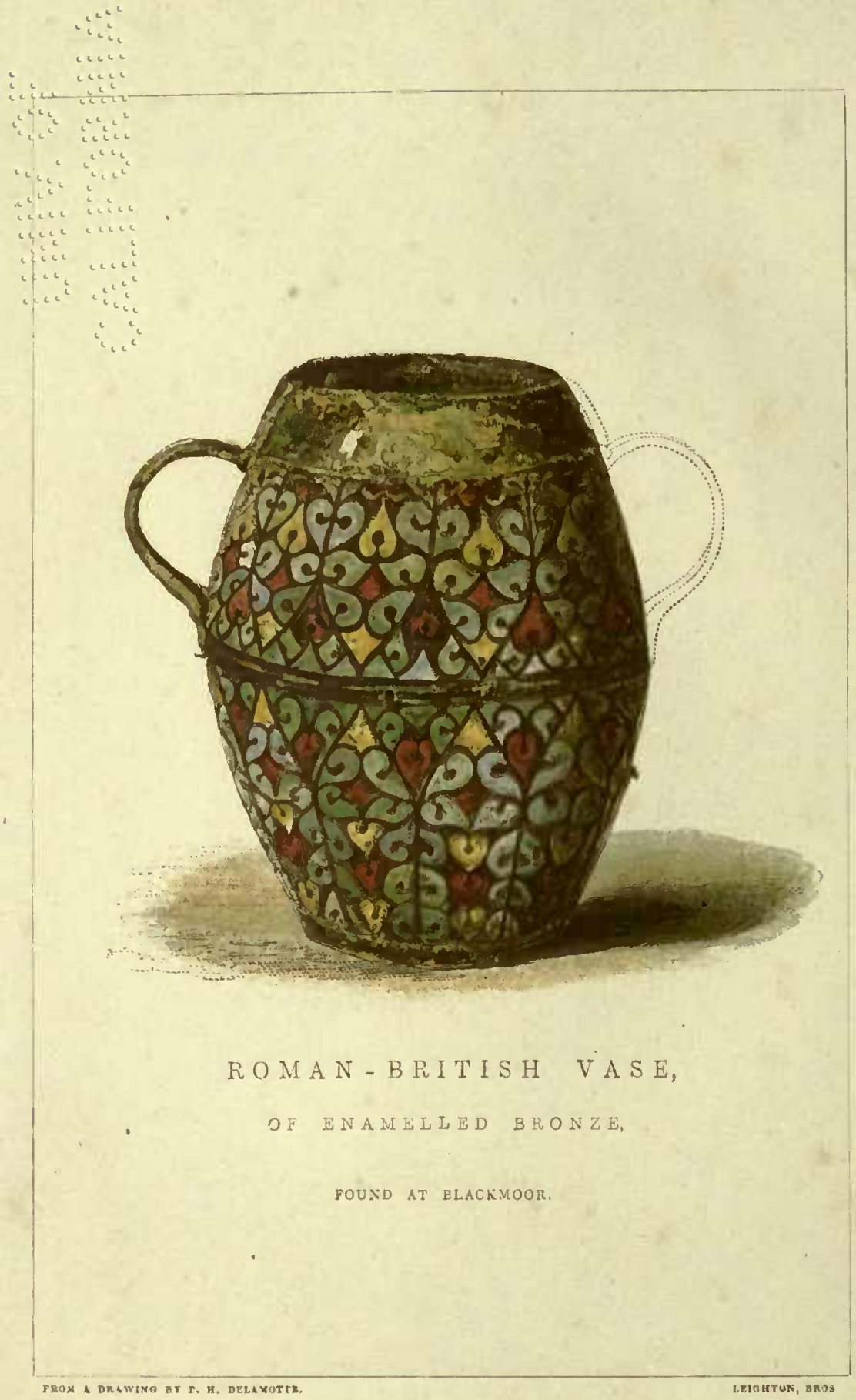




\title{
NATURAL HISTORY AND
}

\section{ANTIQUITIES OF SELBORNE BY}

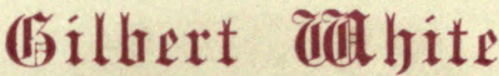

\author{
WITH NOTES, BY \\ FRANK BÜCKLAND. \\ A CHAPTER ON ANTIQUITIES, BY \\ LORD SELBORNE.
}

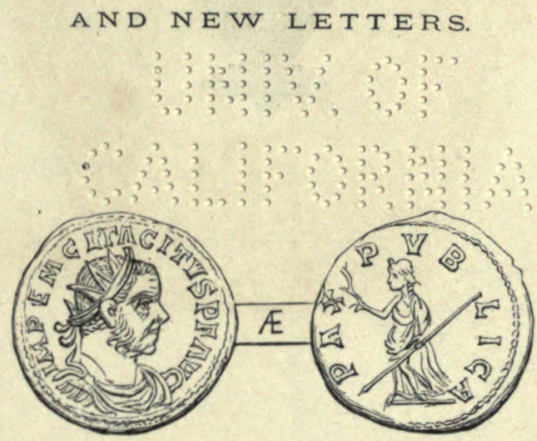

WITH PHOTOGRAPHS AND ENGRAVINGS FROM DRAWINGS BY P. H. DELAMOTTE.

IN TWO VOLUMES.-VOL. II.

ifonton:

MACMILLAN AND CO.

1876. 


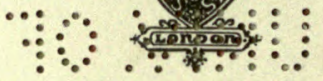

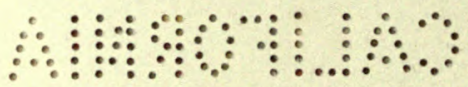




\section{CONTENTS.}

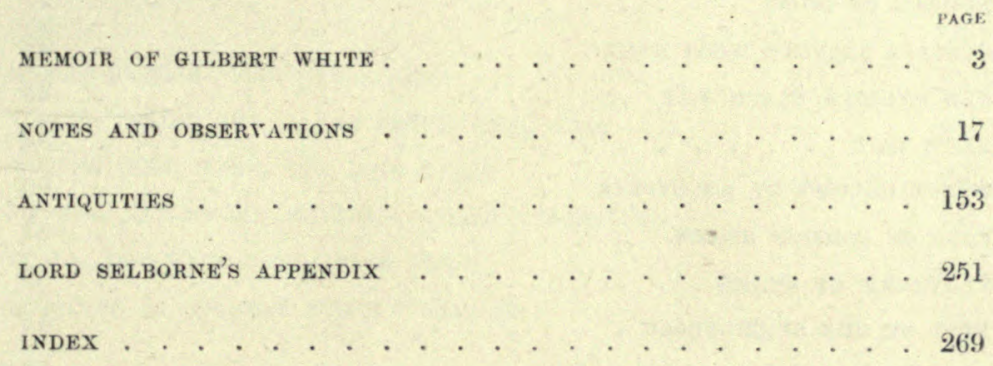




\section{LIST OF ILLUSTRATIONS.}

PAGK RED DEER, EIGHT YEARS OLD . . . . . . . . . . . . . 23 MANTRAPS . . . . . . . . . . . . . . . . . . . . 25 RABBIT WITH DEFORMED TFETH . . . . . . . . . . . . 26 NODULE OF IVORY . . . . . . . . . . . . . . . . . 27 CAPTAIN SALVIN'S WLLD BOAR . . . . . . . . . . . . . . 32 OLD ENGLISH BLACK RAT . . . . . . . . . . . . . . 35 rat's tall . . . . . . . . . . . . . . . . 36 MOUSE CAUGHT BY AN OYSTER . . . . . . . . . . . . . 40 EGGS OF COMMON SNAKE. . . . . . . . . . . . . . 51 VERTEBRE OF SNAKE . . . . . . . . . . . . . . . . . 53 NEST OF THE STICKLEBACK . . . . . . . . . . . . . 54 SERRATED ClaW OF HERON . . . . . . . . . . . . . . . 60 BLACKBIRD'S NEST ORNAMENTED WITH LACE . . . . . . . . . 71 BABY HEDGEHOG . . . . . . . . . . . . . . . . . . 77 NEST OF WREN BUILT BETWEEN TWO STOATS . . . . . . . . . 82 TAIL OF WOODPECKER. . . . . . . . . . . . . . . . 90 FOOT OF WOODPECKER . . . . . . . . . . . . . . . . 91 TONGUE OF WOODPECKER . . . . . . . . . . . . . . . . 91 MUMMY MONKEY FOUND IN A TREE . . . . . . . . . . . . 104 SECTICN OF COW'S HORN . . . . . . . . . . . . . . . . 113 DIGGING PAW OF THE MOLE . . . . . . . . . . . . . . 124 SKIN OF VIPER . . . . . . . . . . . . . . . . . . 135 POISON FANGS OF VIPER . . . . . . . . . . . . . . . 136, 137 RATTLE OF RATtLESNAKe . . . . . . . . . . . . . . 139 
PAGE

POT OF WOURALT POISON . . . . . . . . . . . . . . . . . . . . 140

QUIVER OF WOURALI POISON-TIPPED ARROWS . . . . . . . . 141

AWETO, OR VEgetable CATERPILlaR OF NEW ZEALAND . . . . . 144

GILBERT WHITE'S HOUSE . . . . . . . . . . . . . . . . . . 154

TROTTON CHURCH . . . . . . . . . . . . . . . . . 155

SELBORNE CHURCH, FROM THE ALTON ROAD . . . . . . . . . . . 159

SELBORNE CHURCH, SOUTH AISLE . . . . . . . . . . . . . 160

ORIGINAL BENCHES IN THE SOUTH AISLE OF SELbORNE CHURCH . . 162

SELBORNE CHURCH, NIFW IN CHANCEL . . . . . . . . . . . . 163

AUTOGRAPH OF GILBERT WHITE . . . . . . . . . . . . . . 165

CERTIFICATE OF GILBERT WHITE'S BURIAL . . . . . . . . . . . 165

SELBORNE CHURCH, VIEW LOOKING INTO SOUTH PORCH . . . . . 168

GILBERT WHITE'S GRAVESTONE . . . . . . . . . . . . . . 171

ROGATE CHURCH. . . . . . . . . . . . . . . . . . . 248

MAP . . . . . . . . . . . . . . . . . . . . . . . 250

ROMAN-BRITISH VASE (COLOURED) . . . . . . . . . . . . 252

WATER VESSEL AND LARGE SEPUlChral VASE . . . . . . . . 254

BRONZE CELT, VASE, CUP, AND RINGS . . . . . . . . . . . . 256

SWORDS AND SWORD HANDLES, SPEAR HEADS, \&C. . . . . . . . 258

COINS, AND VASE contaIning coINS . . . . . . . . . . . . 260

SUN-DIAL IN GILBERT WHITE'S GARDEN . . . . . . . . . . . . 283

W. J. Palmer.

P. Roberts.

J. KiRChNer.

\section{ENGRAVED BY}

JewitT AND Co.

W. M. Quick.

F. Andersos 
PHOTOGRAPHS BY THE CARBON PROCESS.

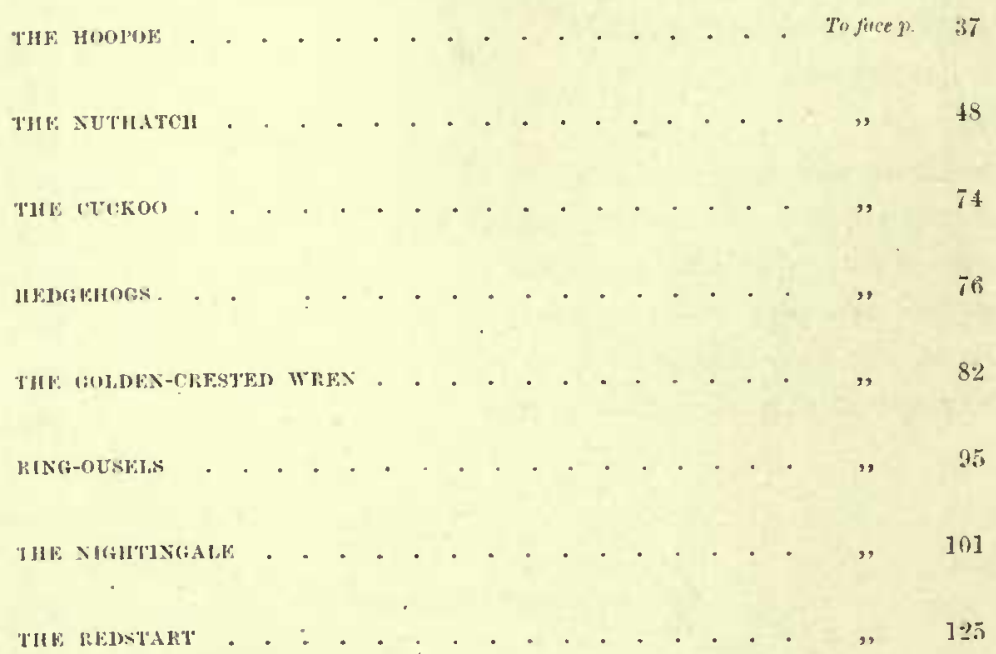




\section{NOTES, OBSERVATIONS, AND ADDITIONS}

BY

FRANK BUCKLAND. 



\section{MEMOIR OF GILBERT WHITE.}

GILbert White-the Father of English Natural History-was boru at Selborne, Hants, July 18th, 1720, in the seventh year of the reign of King George I., and died June 26th, 1793, being seventy-two years and eleven montlis old.

In order fully to appreciate his labours, I will endeavour to throw back the mind of the reader to the prominent events of which Gilbert White might have been witness, or about which he must have heard people talking.

Queen Anne died in 1714, six year's before White was born. The year of White's birth, 1720, was the year of the South Sea Bubble. When he was one year old, 1721, the great Duke of Marlborough died. When he was three years old, 1723, Atterbury was Dean of Westminster. When he was seven years old, 1727, Sir Isaac Newton died. When he was ten, 1730, the great John Hunter, the anatomist and physiologist, and founder of the Royal College of Surgeons, was born. When he was twenty-five years old, 1745, Prince Charles Edward gained Edinburgh after the victory of Prestonpans. When he was twentysix, on October 22nd, 1746, he took his degree at Oxford, as I find from a book in my library entitled, " $A$ Cataloque of all Graduates in Divinity, Law, and Physick, and of all IJasters of Arts and Doctors of Musick, who have regularly proceeded or been created in the University of Oxford, between October 10th, 1659, and October 10th, 1770. Printed at the Clarendon Press, Oxford, 1772." When he was thirty-two, 1752, the new style of consputing the almanac was introduced into England. When thirtyseven, 1757, the conquest of India began under Colonel, afterwards Lord, Clive. When thirty-nine, 1759, General Wolfe was killed at Quebec. When he was forty, 1760, George III. ascended the throne. When he was forty-four, 1764, Canada was annexed. When he was fifty-eight, 17i8, the Earl of 
Chatham died. When he was sixty-three, 1783, America was separated from England.

Gilbert White died on June 26th, 1793. The great John Hunter, the anatomist, died also in 1793-on October 16th, aged isixty fogur, or nine years younger than Gilbert White.

Gilbert White's first letter with a date is Letter X., August 4th, 1767. Thie preface to the first edition is dated January 1st, it 88.: Gilbert White, therefore, must have been writing his letters over twenty years.

White's "History of Selborne" is of itself a most charming book. If the reader wishes thoroughly to appreciate the great merits of the illustrious author, he must not fail to pay a visit to Selborne itself. ${ }^{1}$ I have inspected Selborne and its neighbourhood. The first impression of Selborne, especially when driving in from Alton, is that it is a very pretty place, a perfect type of English woodland scenery and country life. The visitor should carry his "White" in his hand and read the great Gilbert's graphic writings on the very spots described; he should also take a good ordnance map with him, in order to get a general idea of the neighbouring country.

Under circumstances as above Selborne and its vicinity become most interesting. I do not think the village, a sketch of which is given by Mr. Delamotte, p. 12, can have been much altered since White's time, except that some of the shops now have plate-glass fronts, which would astonish Gilbert White considerably if he could see them.

During my visit to Selborne I was most hospitably received by Professor Bell, who now resides, and has resided for the last thirty-three years, in the house where Gilbert White lived; of this an admirable drawing is given by $\mathrm{Mr}$. Delamotte at page 9 . On entering the house, I found myself in an ante-hall with a very low roof and white-washed ceiling. Mr. Bell ushered me into Gilbert White's study. This room in a moment recalled to my mind long dormant memories of my early youth. I was born in Christ Church College, Oxford, December 17th, 1826; my Father was then Canon of Christ Church; his uncle, the Rev. John Buckland, Fellow of Corpus Christi College, then held the living of Warborough near

I Selborne can be reached from London by going from Waterloo Station to Alton, about two hours' journey, and there taking a fly. Selborne is about fire miles from Alton. There is another route from Liss Station on the Sonth Western line. Mr. Blunden of the Queen's Arms, Selborne, has connfortable apartments, and can send his fly to either station. Mr. Blunden is able and always willing to point out the various localities, \&c., mentioned by White. 
Oxford. The Rev. John Buckland was born in 1769, when White was forty-nine years old. John Buckland died, agerl ninety-one, in 1837, when I was eleven years old. It is more than probable, therefore, that my great nncle knew White personally. As Joln Buckland was contemporary with White twenty-five years, and was nineteen years old when the first cdition of White appeared, I can in some measure connect myself with the times of White. When Professor Bell ushered me into White's study, my momory instantly went back to the old uncle's study at Warborough, where I liad often played and eaten cakes and taken tea as a child. The old uncle was a siniple country parson, and must liave lived much in the same style as White did. White's study at Selborne is a plain room, admirably adapted for quiet writing and thought. White's bookcase, in whicl his books were formerly kept, is still in the study. It is a siniple, wooden, close-fronted case, with brass wire netting. On olle end is fastened the thermometer by means of which White took his observations. The tube is not inserted into a case, but simply fixed against the wall: a small ivory index is let into the wood-work of the bookcase. There is a thermometer of almost precisely similar character in the study of Newton Valence parsonage. The tradition is that it was fixed up in its present position by Gilbert White himself.

Professor Bell told me that White's books had been dispersed, and he knew not where they had gone. I can however indicate the titles of some of the books that probably inhabited this case. When my father, the late Dean of Westminster, died, Aug. 14, 1856, a great many of my old uncle's books came to my share. I can therefore state, pretty well for certain, that some of the following books were in White's library at Selborne:-

The Jewel House of Nature, Containing Divers rare and profitable Inventions, together with sundry new Experiments in the Art of Husbandry. Sold by Elizabeth Alsop, Grub Street, near the Upper Pump, 1653.

Three Physico-Theological Discoveries, concerning-1st, Primitive Chaos and Creation of the World ; 2nd, The Geueral Deluge, its Causes and Effects ; 3rd, The Dissolution of the World and Future Conflagration. William Innys, Prince's Arms, St. Paul's Chureh Yard, 1713.

De Statu Mortunruın et Resurgentium Tractatus. Antore Thoma Burnetio, S.T.P. Londini, 1727.

Piscatory Eclogues, an Essay to introduce New Rules and New Characters into Pastoral :-

"Rura mihi et regni placeant in vallibus amnes Flumina, amem silvasque inglorius."

John Brindley, King's Arms, New Bond Street, 1729.

Physico-Theology, or a Demonstratiou of the Being and Attributes of God. 
from His works of Creation. W. Derham, Canon of Windsor, Manby, Westend of St. Pạul's, 1732.

Sermons and Discourses on Several Subjects and Occasions. By Frances Atterbury. Exshaw, Dublin, 1741.

Diseourses on the Four Gospels, chiefly witl regard to the peculiar design of each, and the order and places in which they were written, to which is added, An Enquiry concerning the Hours of St. John of the Romans, and of some other Nations of Antiquity. By Thomas Townson, Fellow of Magdalen College, Oxford. Rivington, London, 1787.

Blair's Sermons, published 1777, and The Anatomical Instructor, or an illustration of the modern and most approved methods of preparing and preserving the different parts of the Human Body and of Quadrupeds. By Thomas Pole, Member of the Corporation of Surgeons in London. "Ad cæedes honinum prisca amphitheatra patebant

Ut longum discant vivere nostra patent."

Inscrip. on Anat. Theatre, Paris. Darlon and Co., Gracechurch Street, 1790.

Mr. Bell informed me there was no portrait whatever existing of Gilbert White. He however pointed out a portrait of an old gentleman who was White's grandfather as well as godfather ; he has a very intelligent face, strongly-marked furrows; certainly the fice of a man of a well-marked character. White's walking-stick was in one corner of the room: it is a pale inalacca cane; on the top is a silver plate bearing the figure of an Heraldic creature, probably meant for a parrot. A portrait in oil of the hybrid between a black-cock and a pheasant is over the door.

In the edition of 1713 there is a general view of Selborne. The figure standing on the brow of the hill, in the old-fashioned costume of White's time, is supposed to be White himself. $\mathrm{He}$ probably wore a clerical wig, knee-breeches and buckles. I tried all I could to get local evidence or stories about White. A villager of the name of Henry Wells-a labourer, nick-named "Farmer" - told me that "White was thought very little of till he, was dead and gone, and then he was thought a great deal of." He then referred me to Mrs. Small.

Mrs. Small is ninety-three years of age. I found her to be in perfect health, and a very shrewd, intelligent old woman. Mrs. Small was born in 1782 , she was therefore eleven years old when White died; she could not recollect much about him except that " he was a quiet old gentleman with very old-fashioned sayings ;" and that "there was in White's time a butcher's shop opposite his door, and a butcher's shop is there uow." "White used to give a number of poor people a goose every Christmas. He was very kind in giving presents to the poor. He used to keep a locust which crawled about the garden." When I said "tortoise"

1 White's tortoise was named Timothy. 
she said, "Ah, that's what I mean." She said that old Dame Terry knew all about White, but Dame Terry had beell deal forty-eight years. Dame Terry must have been over eighty, therefore she must have been contemporary with White many years. Mr Binnic, gardener to Mr. Bell, said that there was an old man of the name of James Cobb who was nearly ninety, and was eight years old when White died. When Cobb saw White coming he used to run and put stones into the ruts and fill them up. White used to give him a penny and say "Good boy, goorl boy." Mr. Binnie recollects Butler the thatcher, who was married by White, and who died aged ninety-two. Mr. Binnie said that Hale who died in 1855, aged seventy-eight, described White to him as a "little, thin, prim, upright man." Hale nust have been sixteen years old when White died. He frequently had tea with White.

Gilbert White was a quiet, unassuming, but very observant country parson. The access to Selborne in those days must have been very difficult (vide page 11). This worthy man therefore occupied his time in observing and recording the habits of his parishioners, quadruped as well as featlered.

Mr. Bell kindly took me to a room up stairs, where he showed me a large number of White's manuscripts. Having thoroughly" inspected White's house and village, I was able to discover why his notes are so disconnected. When he returned home he took a sheet of paper and wrote his observations of the day. I observed the malnuscript was very much faded; it is written on the same sort of paper and with the same kind of ink as letters written by the Rev. John Buckland of Warborough. In those days it is evident that blotting-paper was little, if at all used, for many of the lines were iridescent, as though the dust used instead of blotting-paper was made of brass filings or some such material.

I was happy to hear from Mr. Bell that he is about to issue an edition of White's "Selbome." The numerous manuscripts in his possession will indeed make Professor Bell's book most interesting. Mr. Bell intends his edition to be a classical book, unore fit for the student's library than for general readers. The Professor most generously informed me he was glad to hear I was bringing out this edition, and he promised me any assistance in his power. Professor Bell has lived at Selborne thirtythree years, and cherishes White's memory with the greatest reverence; and into no better hands could White's house, manuscripts, \&c., especially the correspondence with Linnæus, have passed than Professor Bell's.

White's sun-dial still exists at the end of the garden, the 
lawn of which is covered with the most perfect soft grass carpet, on which I saw many water wagtails at work. Professor Bell will doubtless forgive me when I say that his venerable appearance and the surroundings of his house, could not but make me imagine that when talking to him I was talking to the great Gilbert limself. The sum-dial in front of the drawing-room windows at Newton Valence parsonage is said to have been placed there by Gilbert White during his nephew's incumbency.

From page 9 of the book the visitor will at once recognise White's house. It has been little, if at all, altered for nany a long year. Out of this very door and through the lattice-gate Gilbert White passed to and fro into the village bighway. The Plestor, page 5 , is the "Charing Cross" of the village. The word "I'lestor" means playing-place:-I suppose it may be freely translated "playground." The oak which White mentions as having been formerly there, and which was said to be 400 years old, is now represented by a sycamore. This must have been a tree of some considerable size thirty-two years ago, for Mr. Binnie, Mr. Bell's gardener, tells me that at a fair held in the Plestor, and abolished thirty-two years since, one limb of it fell off and destroyed the booth owned by a black man.

I would request the reader to peruse carefully the words of White describing the oak in the Plestor. They read thus:"In the midst of this spot stood, in old times, a vast oak with a short squat body, and hinge horizontal arms extending almost to the extrenity of the area. This venerable tree, surrounded with stone steps and seats above them, was the delight of old and young, and a place of much resort in summer evenings, where the former sat in grave debate, while the latter frolicked and danced before them."

When standing in the Plestor the idea suddenly struck me that the song of "The Old Oak-Tree," which we boys sang with such glee at Winchester Sehool, was composed from White's description of the celebrated oak at Selborne. Not only is the general idea set in poetry, but even White's own words are partially adopted. Here are the words of the song: compare them with the words of the text:-

"Here's a song to the oak, the brave old oak,

Who has stood in the greenwood long.

Here's health and renown to his broad green crown,

And his trusty arms so strong.

In the days of old when the spring with gold

Was lighting the branches gray,

Through the grass at his feet crept maidens sweet, 
To gather the dew of May ;

And all that day, to the rebeck ${ }^{1}$ gay,

They frolicked with lovesome swains.

They are gone, they are dead, in the churchyard laid,

But the oak it still remains;

And still flourish he, a brave oak tree,

When a thousand years are o'er."

The visitor should examine the magnificent yew-tree in the churehyard; its age is unknown. It is twenty-five feet round. The Viear, the Rev. Mr. Parsons, ${ }^{2}$ kindly lent us the keys of the chureh. The tablet eommemorating White's death is on the wall near the altar on the right-hand side of the speetator. An inseription on the tcp reads as follows: "This monument of Gilbert White, M.A., and B. White, Esq., was removed into the ehancel MDCCCX." I understand from the Viear that White was never reetor of Selborne, but only eurate; he was also eurate of Faringdon eighteen years. ${ }^{3}$

The stonework inside the ehureh is eompletely eovered with whitewash, probably the tasteful work of some former ehurchwarden. The Vicar, I understand, eontemplates restoring the inside of his ehurel when suffieient funds are fortheoming. Gilbert White's grave ean thus be found :-On eoming out of the chureh door turn to the left and keep to the left, and at a short distance will be found the gravestone with the simple "G. W." cut on it. The tombstones in this ehurehyard are very muel injured by moss and lichens, whieh have filled up the inscriptions. Over White's grave there ought to be placed a modern monument of some kind. I should venture to suggest polished red Aberdeen granite, sueh as I have plaeed over my father and mother at Islip, near Oxford. The letters should be eut very deeply into the granite, on aceount of the moss filling them up. A strong solution, say ten grains to the ounce, of eorrosive sublimate (i.e., bichloride of mereury) in spirits of wine will, I believe, kill the moss that grows on the tombstones and in the engraved letters, and prevent its germinating again.

At page 10 White mentions the "tenpenny nails in the walls," about-Selborne. I looked abont for these everywhere; at last I found them in abundanee, stuek into the walls of the chureh, and particularly on the wall faeing the visitor on his left as he is about to enter the poreh. I took my hat off to these venerable

1 I find from Johnson's Dietionary that a rebeck is a three-stringed fiddle.

2 I regret to hear that Mr. Parsons died, Sept. 1875, since the ahove was in type.

3 The living of Selborne belongs to Magdalen College, Oxford. VOL. II. 
specimens of a past fashion, which White must have often examined, may be even have placed there.

The deepest well in Selborne is at the hotel; it never fails, and is said to be sixty-six feet deep. 'The visitor should not fail to visit the Zigzag. This is a rough pathway up the side of a very steep hill, which forms part of the hanger or copse which faces the back of Mr. Bell's house. The term hanger is old Saxon for a wood. Holt is also an old Saxon term for wood; we find it in Aldershott, which was formerly Alders-holt, and also in the word Hainhault. The soil of the Zigzag is chalk, easy enough to ascend when dry, but with dew or rain it becomes almost dangerons. At the top there is a splendid view for miles around. At the bottom of the hauger I was fortunate in meeting witl Mr. Wells, farmer, of Selborne. He pointed out to me close to the gate-which, by the way, requires mending - a sliver-leaf aspen, which is said to have been planted by Gilbert White. It is eight feet six round and about a hundred feet high. In the field close by are two large stones, excessively hard and of a peculiar formation, like pudding stonc. Mr. Wells informed ne that when they were making the new road to Alton they found an enormons stone; they "blew him into three, and these were two of the pieces."

While we were examining these stones, as it was just getting dark, a remarkable-looking figure passed us. Mr. Wells informed me that this was an idiot boy who lived in the village. I immediately thought of the idiot boy mentioned by White at p. 197. The letter in which the boy is mentioned is dated 1775 . It seems a very strange coincidence that the secoud villager I met at Selborne should be a successor of White's idiot boy, of exactly a hundred years ago. The present idiot has not yet taken a fancy to bees as did White's lad; he gets his living by needlework with his mother. Towards nightfall he is in the labit of prowling about the place and catching hedgehogs. I subsequently met him, and tried to converse with him, asking him to catch me a hedgehog, but I found he could not speak a word, and took no notice. The poor fellow is quite deaf.

The soil at and about the village of Selborne seems very productive. The visitor should take a walk clown the garden of the hotel from which a very pretty view ean be obtained looking to the north.

At and about this place the vegetation is very luxurious. It may be called a "Primæval English forest." One can easily see from the plauts that there is a constant struggle going on between nature and man; witness how nature is trying to get rid of the onthouse near the hotel at Selborne. An 
ancient ivy-tree is prizing up the bricks with his strong levers, and in time down will come the onthouse. I understand from Mr. Fergusson that the fig-trees in India are destroying the Indian ternples in this way. The regetation, which is pulling down another honse in a field belonging to the hotel, is also worthy of note.

At page 11 will be found Mr. Delamotte's drawing of the rocky lane leading to Alton. White's description of these "hanging laues" is admirable; but they are now much more wild than in White's time a hundred years since. All traffic has ceased in them, a new road having been made to Alton.

The only road from Alton in White's time was along these dreadful lanes, and it is difficult to conceive how a horse and cart could be got through them. This old lane takes a very circuitous course, and comes ont at Alton near the Railway Station. The new road bisects it near Norton farm, one mile from Selborne: the visitor should get out and examine it at this point. I don't suppose that it has been traversed by human being for many years-it looks like a jungle. I should imagine these deep narrow cuttings are frightful traps for fox-hunters. There is another very good specimen of these hanging lanes on the road from Selborne to Liss Station: this is a terrible-looking place, almost dangerous to walk through. A native came to fetch water while we were there; we followed her down a deep rugged incline, at the bottom there was a sinall hole, a little larger than a pail, containing water. This had evidently been dug out for land drainage. The woman took ont of the so-called well two pails of muddy water, and said that it was the only water to be got near the place-it was only fit for a stickleback-pond. This water reminded me of a story I had heard in another part of the country where water was very scarce and very expensive. The curate of the parish, it was reported, used to wash his children in small beer, of which he had a stock in the house, as he found it less expensive than water.

The" only road to Selborne being through these "hanging lanes," it is plain that White could not have had much society. To the existence of these hanging lanes, therefore, I mainly attribute "White's History of Selborne." In these olden times White must have been henmed in on all sides; there were few or 110 human visitor's arriving and departing; the only arrivals and departures that White could notice were those that came through the air, i.e. birds; and of his feathered parishioners he has indeed given us ample reports. The birds, so far as I can 
ascertain, have not changed their dates of arrival or departure since White's time, one hundred years ago.

For the reason that White was so cut off from populous places his attention was greatly devoted to the manners and habits of birds and their arrival and departure. In fact Selhorne was a big birdcage in which White limself was inclosed even more than the birds. It will be observed that White does not go far from home for his descriptions; his observations were takel within a small radius of his house. He had great opportunitics of maling observations, as the place was so secluded and quiet. White says little or nothing about fishing, there being no river, and the ponds inore or less dried up.

The landlord of the "Queen's Arms" kindly drove me round Selborne to show me the principal objects mentioned by White. I first examined some hop gardens : one side of one of these pretty English vineyards was protected by gigantic walls of hurdles, four hurdles high, one above the other. These are placed to keep the wind off the hop plants. From their produce is made trie linglish "Vin du pays," i.e., beer, and from them is brewed the noted Alton ale.

I called upon Mr. Bromwich at his farm on the Selborne estate, where I was most kindly received. The view from Mr. Bromwich's lawn, over a vast extent of hop gardens, in which the foxes can be heard barking at night, is exceedingly beautiful; if an enemy should attempt to attack London, Mr. Bromwich's farm would probably be chosen as a commanding position. Mr. Bromwich showed me a capital invention for sulphuring the hops; dust sulphur is blown about to kill the mildew.

This machine is made of iron; it is drawn by a horse between the rows of hops; and the wheels, as they run along, turn a fan. This fan blows out, with very great force, jets of fincly powdered sulphur, through two iron funnels that look like horses' ears. The sulphur is sometimes driven twenty feet high, and covers every leaf of four rows of hops at one time.

I examined the place where the big oaks stood, in a place called Losels Wood (see page 5) in White's time. The cultivation of oaks still goes on at this place, and seems to be very successful.

Shortly afterwards I passed the splendid residence lately erected by Lord Selborne, and all of a sudden I came in view of Wolmer Pond (see page 15). I was amazingly surprised to find this grand pond nearly dried up-a pitiful sight to a fish-culturist. The culture of fish-ponds is a subject to which I have pairl great attention. I was just reading the following passage from White: - "This lonely domain is a very agreeable haunt for many sorts 
of wild fowl, which not only frequent it in the winter, but breed there in the summer,"-when up rose nine wild ducks; they flew round two or three times and then went straight away. I looked for footmarks round the pond, but could find none of any wading birds near the water. A great portion of what was once the pond is now a mass of different kinds of mosses. All kinds of birds seemed scarce. On the south side of the pond there were some large eaves in the sandstone; for what purpose they were made I cannot say. We then had a turn round the common, to try for snakes, vipers, \&c., but could find none.

It will be observed that White writes as follows at page 101: "I wish it was in my power to procure you one of those songsters; but I am no bird-eateher, and so little used to birds in a cage, that I fear if I had one it would soon die for want of skill in feeding."

When I undertook the task of re-editing this book I was determined, if possible, to do my best to implant upon the original text as much more information as the spaee afforded would allow. White acknowledged limself that he was no bird-eateher.

I have been, therefore, most fortunate in obtaining the services of Mr. Charles R. Davy, bird-eateher, who for thirty years has largely dealt in all kinds of British birds, both "seed-eating" and "soft-meat." Mr. Davy is thoroughly conversant, from practical observation, with the habits, manners, and treatment of English birds. He reeeives annually large quantities of live birds from various parts of England for shipping orders as well as for home distribution. Mr. Davy, Mr. Searle, my secretary, and myself, have gone through White's remarks two or three times, and I have placed Mr. Davy's observations on reeord. I trust they will be found interesting to my readers.

At page 14 we read, "The parish swarms with children"- this was a hundred years ago. The parish still swarms with ehildren, but they are not exactly the same children as in White's time. The ehildren that White may have seen, and probably did see, are now old Mrs. Small and Mr. Cobb.

These suceessive generations following one on to the other remind me of a passage in my father's sermon preached before the University of Oxford. ${ }^{1}$ We read in the Dear's sermon:-

"From the universal condition of all organie beings upon earth, man himself has no exemption; to him as to everytling around him, the inevitable termination of life is death.

"As of the green leaves on a thick tree, some fall and some

1 "An Inquiry" whether the Sentence of Deatl Pronouneed at the Fall of Man included the Whole Animal Creation, or was Restricted to the Human Ruce." Murray, Albemarle Street, 1839. 
grow; so is the generation of flesh and blood, one cometh to an end and another is born."

Selborne seems to abound also in cats as well as children; every cottager seems to keep a cat. Perhaps there are no more cats here than in any other place. The appearance is probably due to the place being so quiet that cats leave the cottacres and lazily prowl about out in the roadway. On the top of White's house I watehed for some time a white puss wandering over the tiles. She was evidently after the chimney swallows. These poor birds were greatly terrified, and kept working round the cat as startings or jackdaws would round a hawk; they were screaming loudly with fear. Their nests were in the chimneys, and if the cat got down the chimney she could, I dare say, have got a weakly-tlying young bird for her trouble.

At page 3 there will be found Mr. Delamotte's pretty sketch of the Well-head. White knew nothing about hatehing salmon and tront by artificial means. I have never seen a better place than the Well-head for breeding tront and salmon artificially. I propose at the next fish-breeding season to fix up a trouthatching box at the Well-head, in such a unanner that it will not interfere with the women who come to fetch water. Salmontrout even now sometimes ascend the river Arun (page 3) as far as Pulborough, and my friend Mr. Constable, of Arundel, breeds many salmonidæ; every year he rears up his young fish to a certain size in the water tank at the top of the brewery. Some of the Well-head water goes into the Arun.

The water flowing from the Well-head runs into a water-cress bed-a better nursery for young tront and salunon I never saw. If I do not breed salmonidæ at Selborne next year I shall certainly, with the permission of the local proprietors, turn down a number of trout and salmon into this brook. Some of the salmon may possibly go down the Wey, and thus assist Mr. Ponder and myself in our efforts to salmonize the Thames.

At page 77 is to be seen the sketch of a very ancient wheel for drawing up water. It is in the house of Mr. Loe, shoemaker. The woodwork of the wheel presents a fine specimen of dry rot and the work of wood-borers combined. If not looked to, this wheel may possibly cause an accident some day. It ought to be pensioned off, and hung on the wall at the side of the well.

The Rev. A. N. Campbell-Maclachlan, Vicar of Newton Valence, adjacent to Selborne, kindly asked me to luncheon, and showed me a note-book of Mr. Edmund White's of Newton Valence, who was probally nephew to Gilbert White. It begins thus:-"A journal of weather and other occurrences 
firom February 10, 1775, when the last book ended January 28,1775 ; when I was seized with a fit of the gout."

The following interesting entry records Gilbert White's dining with him. "Sunday, Deeember 6th,-very fine; Selborne, G. dined here." "Sunday, March 25tl,-_Chiff-chaff, enrlew." Mr. Maclachlan also showed me a very ancient register of $29 \mathrm{th}$ Henry VIII. He also pointed out to me, by means of an old Army List of March 15th, 1786, who the Honourable Daines Barrington was. Under the heading Gibraltar ${ }^{1}$ are the following entries :- "Governor-General G. Augustus Elliot, K.B.," (afterwards made Lord IIeathfield, for defending Gibraltar, 1787). "Honourable Daines Barrington, Com. of the Stores, \&e., $£ 547$ 10s. salary." From Mr. Maclachlan I learnt that the late Bishop Wilberforee had been a frequent visitor at Newton Valence. The grounds of the parsonage adjoin the down, or sheepwalk, which Gilbert White, Letter I., describes as "a pleasing park-like spot, of about one mile by half that space, jutting out on the verge of the hill-country," \&e. Immediately in front, with only a valley between, and entirely included within the parish of Newton Valence, rises Nore hill-to quote White again, "a noble chalk promontory, remarkable for sending two streans into two different seas." From the top of that hill, the Bishop was wont to say, he could discern the observatory which he had ereeted on the crest of the down, above Lavington House. The Bishop, as is well known, was an intense admirer of beautiful scenery, and no mean naturalist-as shown by the volume of essays from the Quarterly Review, republished since his death, and by the beautiful collection of Sussex birds, which be had for the most part made himself, and which forms one of the adornments of Lavington House. It will be remembered how touchingly, at the inquest upon the Bishop's honoured remains, Lord Grauville related the points of their last conversationespecially the Bishop's animation while observing the scenery through which they passed on that beantiful July afternoon, and while drawing notice to the adaptation of the trees and shrubs to their several soils.

I have lieard that just a moment before the Bishop fell from his horse lue said to Lord Granville, "Hark! do you hear that nightingale singing so benutifully?"

In the belfry of the church of Newton Valence there is a beautiful tablet with the following inseription:-

${ }^{1}$ It is a remarkable coincidence that Gilhert White's brother should have been military chaplain at Gibraltar. Gibraltar is mentioned several times by White. 


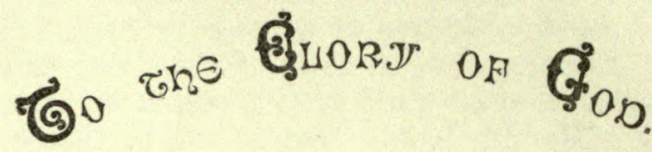 \\ IN MEMORY OF
}

\author{
THE \\ firist Confirmation belo in this $\mathfrak{C}$ burrby \\ BY
}

SAMUEL WILBERFORCE, D.D., LORD BISHOP OF WINCHESTER,

EASTER DAY, 1871 ,

Two Large Bells were added to the Peal, and the Three Smaller Restored and Re-hung.

BY

ARCHIBALD NEIL CAMPBELL MACLACHLAN,

VICAR AND PATRON.

It gives me great pleasure thus to be able to connect the memory of the late Bishop of Winchester, whom so many of us had the honour and privilege to know and respectfully to admire, with Selborne and Gilbert White. 


\section{NOTES AND OBSERVATIONS.}

Wyci Hazel, OAKs, p. 5.-My friend Mr. Menzies, DeputySurveyor of Windsor Great Park, a great authority on forest trees, kindly sends me the following note:-

The Wych Elm referred to at page 5 must lave been a renliarkably fine one, and, judging by what I know of others, probably 500 years old. The Wych Elm is not nearly so common is the English Elm. The distinguishing feature of the former is its rough serrated lcaf. The distinguishing feature of the English Elm, especially under fifty years of age, is the cork-lookin excrescences upon the points of the branches, or, as Shakespeare in "Midsummer-Night's Dream" has stamped it past mistaking-

"The barky fingers of the Elm."

The finest elms at Windsor and in the Playing Fields of Eton are about 300 years old, and 15 feet in cireumference; but the average age of an elm is about 100 years less than this. It is not known when the Wych Flm was introduced into England-if, indeed, it is not indigenous; but it is believed the liomans introduced the common elm when they brought the vine, as the two are always associated in the Latin poets. Mr. White says particularly that this Wycl Elm must have been a "planted" tree. He does so because there was a great controversy in his time and for many years afterwards as to whether trees, especially oaks and all hard-wooded trees, which have a tap-loot in their youth, would grow to any size when transplanted from their original seed-bed. It has really only been settled within the last thirty years, that transplanting young trees is not of the slightest consequence if properly done: and that the tap-root in them all is absorbed (like a tadpole's tail) in a few years, and cutting it off makes no difference. No tree VOL. II. 
benrs transpianting better than an elm, up to fifty years of acre; 110 tree is more easily killed by disturbing it in any way in its old age.

The Vast Oak, growing in the Plestor, camnot have its age estimated, as no dimensions are given. As a rongh rule, there are ten years' growth in every inch of radius of the stem. The remarks I have previously made will show why he specially speaks of the tree having heen "planted." Many people would, at that time, have dispnted what we now know, and the system we now have of growing plants in nurseries and then sending them out in thonsands was almost unknown 100 years ago, especially with all the hardwood trees. It is not known to what age or to what dimensions an oak will grow with fair play. In fact, I have never known an oak die of pure old age. Either lightning or neglected wounds have been the cause of death; you may reeover an oak in its last stage by removing the cause of deeay.

William the Conqueror's Oak at Windsor is certainly 1,200 to 1,500 years of agre, and is about 33 feet round; the Kingr Oak is 35 feet round, and as old; Qneen Elizabeth's Oak, 29 feet round, is probably 1,000 years old; the age of Shakespeare's Oak it is impossible to estimate, as it is mow only a white shell with a few bleached hoary branches.

As for the "tall and taper' oaks," White speaks of, they were sot very common in England, except in the Weald of Kent, Surrey, and Sussex, which have naturally supplied ship-timber for hundreds of years.

Chancer, writing in the 14 th century, describes such a wood. He says:-

\footnotetext{
"These trees were set that I devize

- One from another in assize.

Five fadom or six : I trowe so.

But they were ligh and great also."
}

These trees could only have been high and great by being grown in the manner Mr. White describes as oaks naturally are a spreading tree and only go up straight when crowded. The great art in managing oak woods for timber is to keep them to this upright growth and yet not deprive them of a sufficiency of branches, which in reality are the lungs of the tree. This distinguishes the English from the Continental system of management.

It is not known what produces the excrescences on the oaks ; 
but the tree is subject to them, and the wood when eut $u p$ is beantifnlly marked with a multitude of sinall circles like the finest walnut or bird's-eye naple.

I forgot to say, with regard to the oak which was blown down, that no tree which fell in this way, if of any size, ean be put up again and live. I have frequently been consulted, but never advise it. The case is hopeless.

Ravess, p. 6.-These birds are now getting very scarce, by reason of the old ones being shot down and the young ones taken. Davy, the bird-catcher, used to get a quantity of young ones, as many as four nests in a season, from the Isle of Wiglit. The young ones of late years have come from Plymontl.

Three or four years since, there were several nests on a gentleman's estate at Romford. Formerly there were numbers in Hainhault Forest.

Bird-dealers formerly paid 30s. per dozen for good strong young ravens, now nestlings feteh 15 s. ench wholesale. The shepherls in the Isle of Wight say ravens prey largely upon wild rabbits, young and old. Ravens are, in the. Isle of Wight, destructive to newly dropped lambs.

Mr. Bartlett receives anmually several ravens at the Zoological Gardens. They are kept by their owners till they get troliblesome, and are then sent to the Gardens.

Holt axd Wolmer Fonests, p. 25.- $\Lambda$ correspondent writes me:-

"I know both Holt and Wolmer forests well. The former is on the Gault Clay, with overlying drift beds; the latter' upon the Greensand folmation-terms unknown in White's time. All that remains of both forests is the property of the Crown, and they are covered with thriving young plantations. The old trees are all gone, and the whole is a most uninteresting country-nothing to see, nothing doing, and no one living there except a few woodmen in charge.

"The ironstone to which Mr. White refers as existing in $\mathrm{H}$ olt Forest was common to all the Greensand formation, and used to be smelted in Sussex by wood till the coal-smelting drove it out of the market.

"The inatter to which he refers about the disputes as to the timber was common over all Fugland in those clays, as it was not known often to whon trees growing on the wastes kelongred. All was finally settled and decided by the Disafforesting Acts passed in the years from 1815 to 1820 , and the commons and forests divided into severalty among all the different owners."

The railings round St. Paul's Cathedral, a great portion of 
which has lately been removed, are made of Sussex iron. I cannot here resist putting on record the origin of the pattern of the railings which surround the inclosure in Hanover Square. It is this:- Sir Francis Chantrey, the sculptor, my godfather, had just finished his statue of Pitt when he came down to visit my father at Oxford. The Dean (then Canons of Christ Church) introduced Sir Francis to the Judge of the Assizes. The judges at Oxford are always received and accompanied by "javelin men," the attendants, who carry a spear, at the shoulder of which is a fringe of thick worsted tassels. These javelins had been placed in brackets along the wooden pen which keeps off the public. My father, sitting on the bench, saw these javelins - they had been consulting together about the pattern of a railing for Hanover Square-touching Sir Francis he said, "There are your railings." This, then, was the origin of the "javelin" railings in Hanover Square.

RED DEER, p. 16.-A gentleman well cognizant with the management of deer parks writes me:-

"The great evil of all the forests and chases in England was the total absence of system and the want of an adequate force of keepers and watchers to protect the deer. Certainly very stringent laws were enacted, and very heavy penalties were in force, but in the days when 'police' had not been invented, and when almost free license reigned supreme throughout the land, we cannot wonder at the wholesale deer-stealing and poaching that prevailed, when detection and capture of the culprits was almost impossible, and when the temptation to run what slight risk there might have been was too great for the young and active to resist.

"The mischief done by herds of deer to crops is very great, but the evil is generally traceable to the cruel neglect of many a proprietor of forest and park, who leaves the herd to fight for themselves in the winter, instead of providing them with ample provender against the time of scarcity." A very able pamphlet on "Deer, their Habits and Management," by "Underwood," 1870, can be obtained at Land and Water Office, 169, Fleet Street.

Many very curious and interesting things are found in the bed of the Thames, by men who work the mnd-and graveldredging barges. Whell at Windsor, I got together a fine col. lection of bones, especially of red deer, horse, and roebuck; the dredger-men called these "water bones:" they take a beautiful polish. The Anglo-Saxons had tame deer, which were great favourites; they taught them to decoy wild ones into nets. 
Deer were not inclosed in parks till the fourteenth century. James I. inported a great number of deer, probably rein-deer (though the books say fallow ·deer), from Norway into Scotland, and introdnced them into his chases of Enfield and Epping.

The progressive Rate of growty of the llolns of Rit DEER is a most interesting subject. By the kindness of the authorities of the museum at Exeter, I am enabled to give drawings of a series of Red Deer horns. These horns were shed by the same deer, and earefully preserved as they fell off. The following is the account of this most interesting and unique series :-

"The six pairs of horns belonged to the same animal, reared from $\Omega$ ealf by John Clarke, of Lynton, N. Devon, and were shed anmually in the spring. The drawings illustrate the mode of growth of the horns or antlers and their annual increase in size from the first to the eighth year of the animal's life. This individnal was kept in a dry grass field without water, and was never supplied with any artificial food whatever. Before the animal was one year old the horms began to appear, abont the latter end of May. In the following April these were shed, when they were nine inches long (Fig. 1). A very short time afterwards, others began to be developed, and in the latter end of April following these were also shed, though not both on the same day. These had 'brow,' 'bay,' and 'tray,' with upright -altogether upwards of two feet in length (Fig. 2). In his fourth year he had the same kind of antlers, with two points on top on one horn, and two and an offer on the other (Fig. 3). In his fifth year, antlers as before, with two points and an offer on each horn (Fig 4). In his sixth year, antlers the same, with three points on each top. In his seventh year, antlers as before, with four points on each top (Fig. 6). In his eighth year (when he was killed), antlers as before, though on one horn the points were not so perfect as in his seventh year. It will thus be seen that this deer had seven points on each horn, making together fourteen (Fig. 7).

"The age of the stag, or male red deer, which alone bears horns or antlers, may be pretty easily determined by the number of the branches till its seventh or eighth year; but after that period the increase of those parts is not subject to any fixed rule. The oldest have seldom more than ten or twelve branches.

"In England, at the present day, the red deer exists in a state of nature only on Exmoor, a wild tract of country on the borders of Deron and Somerset, from whence came the animal whose head and horns are here exhibited. The red deer still 
occurs in Ireland, and abundantly in the Highlands of Scotland. It formerly extended all over the British Islands, and was

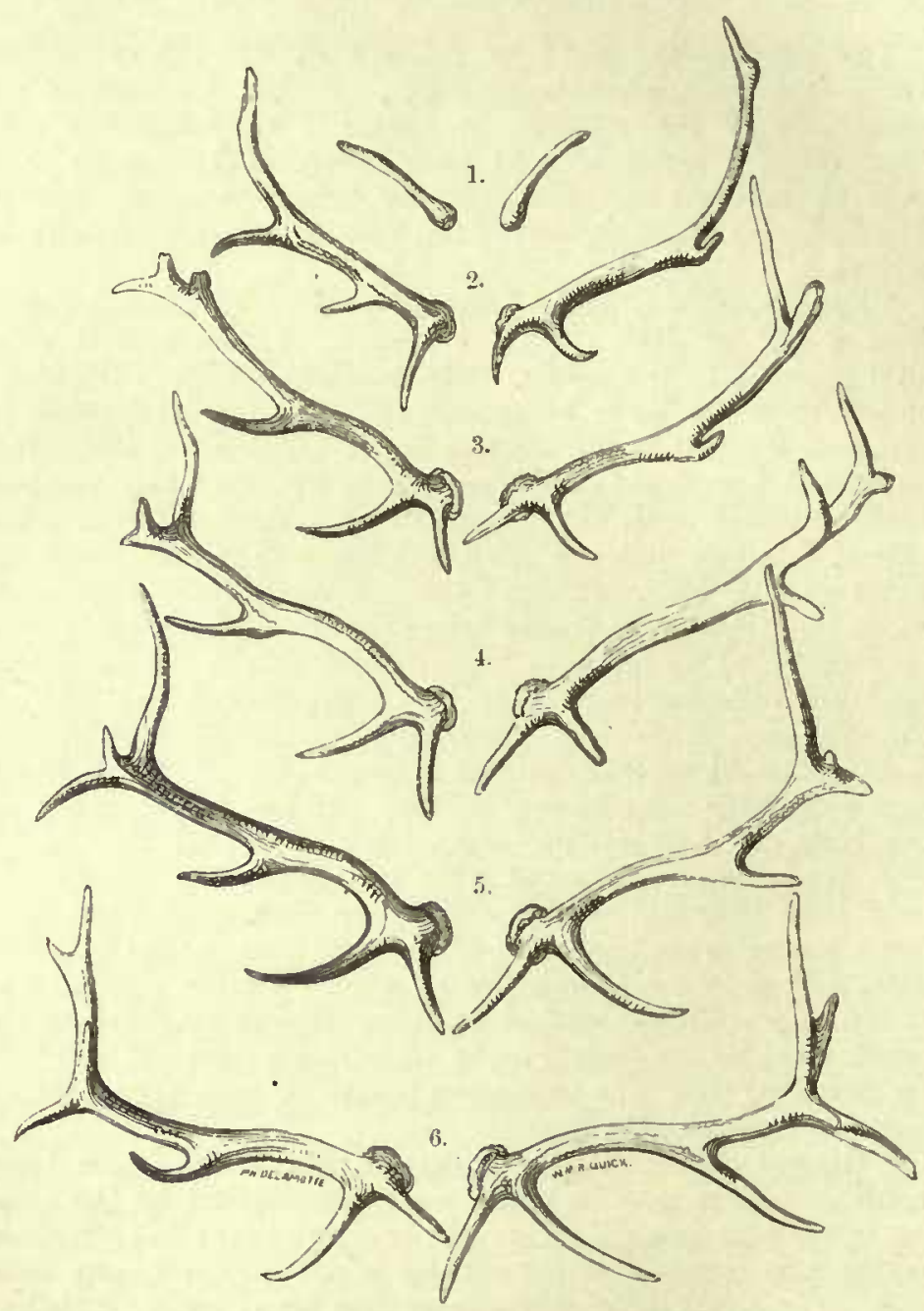

FTGS I TU 6. -PRUGRESSIV E GRWTH OF RED DEER HOR NS.

exterminated on Dartmoor, Devon, only three generations since, hy the stag-liounds of the then Duke of Bedford." 
The above account is from the pen of Mr. J. Clarke, who has published a "Treatise on the Growth of the Horns of the lied Deer." (A. P. Woorl, Bookseller, Barnstable, 1866.)

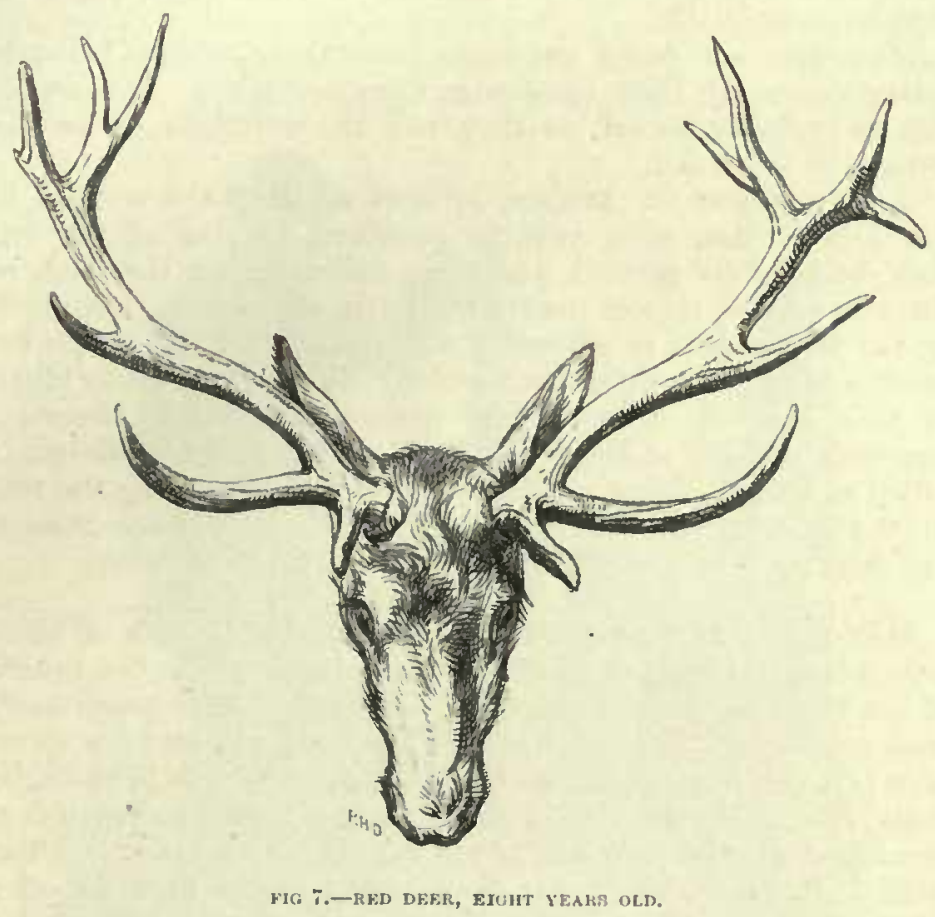

Spiracula of DeEr, p. 45.-Mr. Henry Sawyer, head keeper of Richmond Park, writes me:-" I eannot think that there can be any respiration from the cavity in the deer's heal, below the eye ; the skin covering the cavity is of the same nature apparently as the other part of the skin, and it adheres very closely to the bone, so that there is great diffienlty in skinning it without eutting the skin; there is certainly no orifice in the skin. This view is strengthened by the example which I gave in my treatise on deer, where a stag, closely pressed, ran into the water, and in his anxiety to hide himself, let the water into his nostrils and was drowned. This my father was an eye-witness of. If this envity would have supplied the respiration, this need not have happened, as undonbtedly he kept his eyes open. Deel' 
do not thrust their noses under water when they drink. There is no doubt that it is very desirable for hunters and race-horses to have large nostrils. Deer, when they are hardly pressed, rum with their month open, which a horse does not. I camnot think that it wonld be necessary for an animal at slow work to have its nostrils slit."

Most deer and many antelopes have these curions tear-pits uncler the eye. They contain a waxy secretion. The use of this is probably sexual, as they rub the secretion on to the boughs of trees, \&c.

$A$ comnoisseur in renison informs me that the venison of the fallow cleer, as a rule, is preferred to that of the red leer, being finer grained and more delicate; but the flesh of the two species seldom meets with fair comparison, inasmuch is the fallow deer is genernlly shot in an inclosed park-his exact age and condition are carefully noted, and care is taken to pick him off in his fullest perfection; whereas the stag, generally roaming at large in a forest or extensive woodland, is killed at hazard and at ranclom, his hearl alone guiding the rifle in its selection. Red deer venison, if of the proper age, season, and fatness, is by many allowed to be second to no other.

Man-traps and Spring-guns, p. 18.-In Gilbert White's time man-traps and spring-guns were probably set for the benefit of the Waltham Blacks which he mentions. These instruments were made illegal in 1826 . I have in my $1 n n s e n m$ a very fine specimen of a man-trap given me by Mr. James Wiseman, of Paglesliam, Essex. The drawing opposite is taken from a photograph of two man-traps that belonged to my late friend Sir Robert Clifton, then M.l'. for Nottingham; they act upon the principle of a lat-trap, with very strong springs at each end, and inflicted fearfnl wounds upon the human leg. Their size will be seen from the height of Sir Robert's gamekeeper, who has his hand upon the top of the trap. Sir Robert put this man into one of these traps and had a great difficulty to get him out again. In the Ashmolean Musenm at Oxford there are three very fine specimens of man-traps, also a spring-gun. The spring-gun is abont the size of an old-fashioned navy pistol. It turns upon a pivot; wires were attached to it, which were suspended in all directions annong the bushes about the height of a man's knee; by a simple meehanism the gun revolved and went off exactly in the direction of the wire which was tonched by the man's leg. Close to these traps in the Ashmolean museum is the burnt end of a wooden stake, which was, without a doubt, used at the martyrdom of Cranmer, Latimer, and Ridley. 
Rabit witu Deformed Tfeth, p. 19-It often happens that rabbits are shot with teeth deformed in the manner represented in the engraving on the next page. It will be observed that the two lower teeth project upwards and forwards so as to come almost on a level with the top of the rabbit's nose. In order to understand how this deformity came about, the rearler should examine the teeth of the next rabbit sent up to talle. He will find that the tips are sharp and chisel-like, and that the

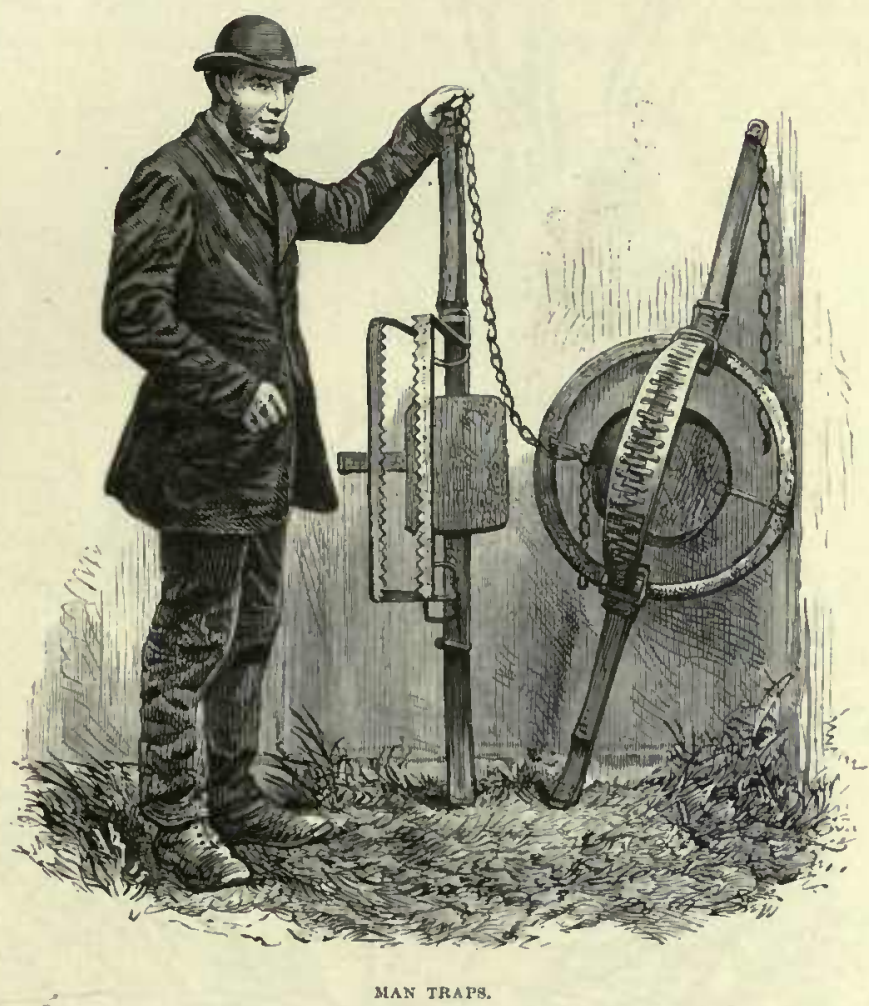

lower end of the tooth is filled with a gelatinous substance. T'he rabbit, by continual gnawing, wears away the tips of these rodent teeth; as the tooth is continuously growing, the soft jully it the root gradually hardens itself into true tooth structure. The fou rodent teeth are thus regularly wearing each other down, and, as they all grow at a similar rate, they keep each other level.

Should any one of the four teeth gret injured or knocked ont VOL. II. 
of gear, the opposing tooth still continues to grow. In the rabbit now before us a shot or some other injury has partially dislocated the lower jaw; the lower teeth, therefore, do not correspond with those in the upper jaw, they are therefore grown to the length of one inch and a quarter.

There is great variety in deformities of rabbits' teeth, and I

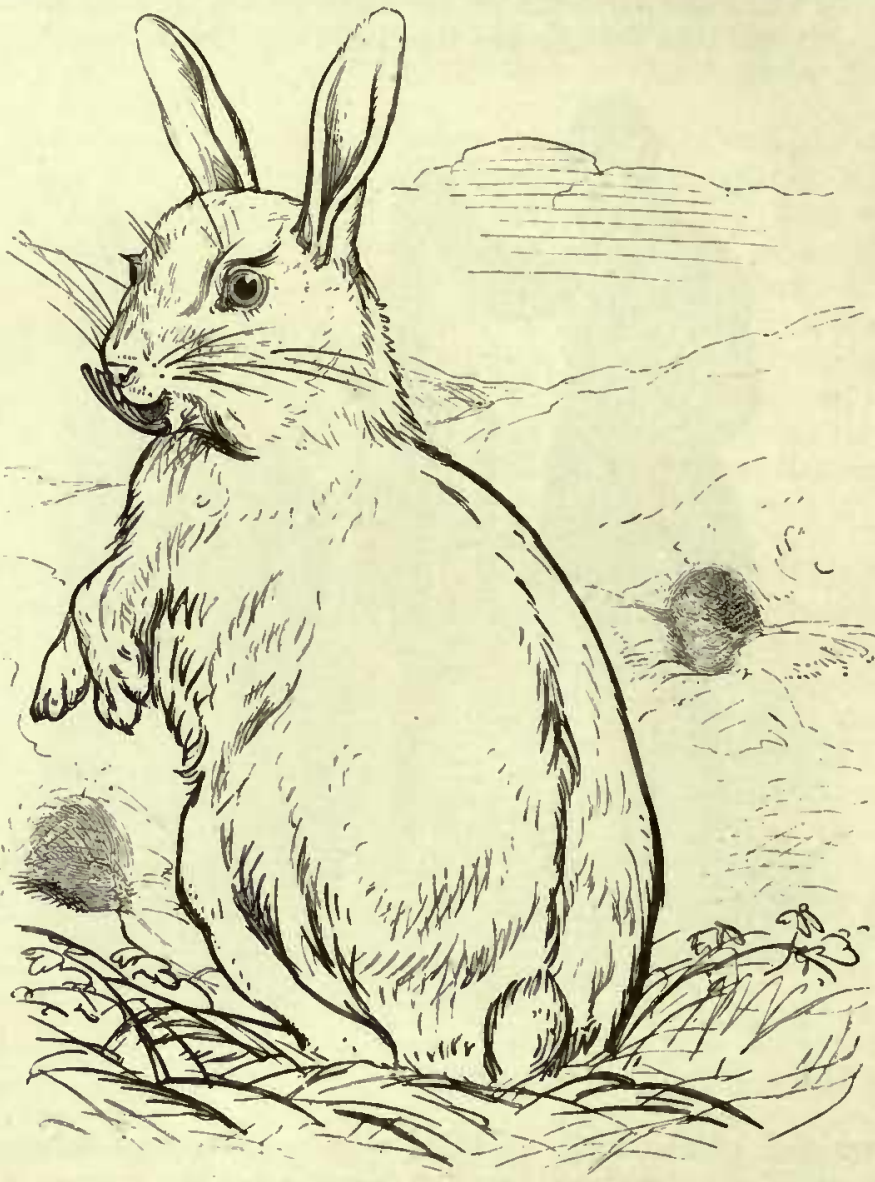

RABBIT WITI DEFOHMED TEETIK,

have in my museum several fine specimens; some teeth are almost in the shape of a ring, others are spiral like a corkscrew.

The elepliant's tusk grows from within outwards, exactly in the same way as does a rabbit's tooth. Musket balls are often found 
inside elephant's tusks, completely grown over with ivory. If we drop a shot into the cavity of the tooth of a boiled rabbit, and imagine the tooth put back again into the rabbit's jaw to grow, it will give some idea how bullets are sometimes inbedded in solid ivory without any apparent hole by means of which they have obtained an entry.

The engraving represents a specinen of a remarkable abnornial growth from the hollow part of the tusk of an elephant. I found nothing in the cavity, but it is, lowever, evident that nature was attempting to cover up a foreign body which probably

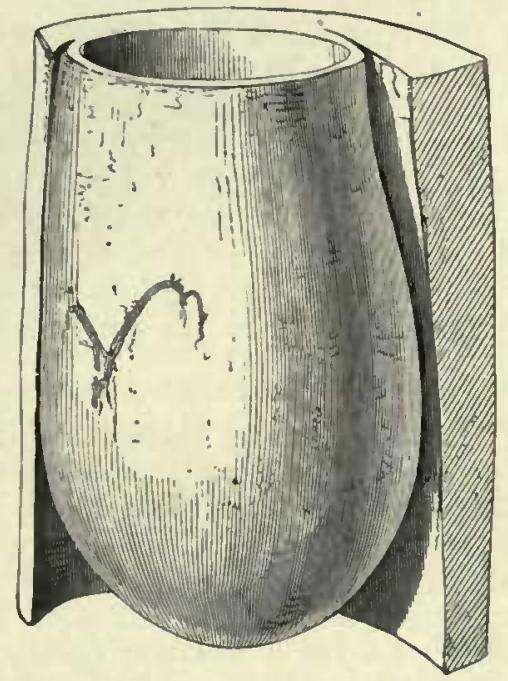

NOUL"LE OF IVORY.

was a bullet. The specinien was presented to me by Messis. Brooks \& Co., of Cumberland Market, who cut up great quantities of ivory in their business.

Mr. Lambton Young gives me the following new plan for bolting rabbits from their boles. He writes :-

"I have met with a novel way of ferreting for rabbits in Jersey. On the estate of my friend is a rabbit-warren, but lately the rabbits were found to be diminishing in numbers very rapidly. A watch was set, but there were 110 guns heard, ol suspicious persons observed to go on the ground; the only frequenter of the place was an old lame fisherman, who walkerl with a broomstick to aid his steps. At last suspicion attached 
to this old fellow, but on being questioned, he said he only passed the warren to go down on the rocks to get his rod and catch grey mullet; but, acting on the advice of one of the workmen in the garden, my friend kept a look-out, and at last saw the lame old rascal, when in the warren, look round first to see if he was observed, and sit down above the most frequented burrow. He then took from his pocket a couple of the small green crabs so common on the seashore and put them into the hole, and they at once ran down; soon after, up bolted a fine rabbit, and our infirm friend knocked it over at once with his broomstick and hid it in a furze-bush. He then repeated the trick, and soon killed five fine rabbits."

Mr. Matthias Dumn increases the efficacy of the above prescription thus:- "Allow me to say the cral, to do the work as he ought, when put in the rabbit-hole, nust have a lighted end of candle stuck fast to his back, with a little clay or grease to hold it firm, and a formidable creature, thus armed, is he; for neither fox, badger, nor rabbit can withstand his fiery torch. This, then, is the impromptu ferret used in this neighbourhood, and the business is suid to be a failure without the candle. Hence I expect the old man had the same machinery at work to get the rabbit."

Remarkable HYBRID.-I have heard the following story of the great Duke of Wellington being completely sold by a showman. A man had advertised an exhibition of a hybrid creature between a tench and a rabbit. When the Duke went to exanine it, the exhibitor told him he was very sorry he could not show the specinen itself, as it had gone to Court to be shown to the King; but, if it was any satisfaction, he wonld show him both the father and the mother stuffed and in glasscases. Mr. Bartlett tells me that more than once a hybrid between a cat and a rabbit has been brought to him. He says a cat with a short tail will not prove the argument; he wants a rabbit witl a long tail.

Woolmer Forest, p. 22.-Large lakes such as those mentioned by White often contain one large pike, who is king of the pond. A good example of this is the huge pike that I obtained through the kindness of his Royal Highness Prince Christian, and which I have described as follows:-His Royal Highness I'rince Christian was so very kind as to send me, in October 1874, in charge of Mr. Keene, head fisherman in Windsor Park, the most splendid pike I ever beheld. Having understood that liapley Lake, wear Bagshot Park, which belongs to the royal 
domain, had not been dragged for upwards of fifty years, $\mathrm{Mr}$. Keene put in the nets, in order to report to the Prince what stock of fish he had there. The net brought out a number of carp, tench, \&c. Keene thought from the commotion in the net, that he had caught an unusually large fish. When the net shoaled he was delighted to find a monster pike in it; the fish rushed between his legs and nearly upset him. He took his prize at once to Cumberland Lodge to the Prince, who was good enough to send it on to me immediately. This magnificent fish weighed no less than thirty-five pounds; length, three feet ten and a half inches; girth, two feet. I never saw a fish in such perfect condition before: the eye was exceedingly beautiful, the head shone like smoked mother-o'-pearl, every scale was perfect, the fins as red as those of a perch; four black bars extended some distance from the tail upwards, giving the fish a zebra-like appearance. Mr. Keene asked me what $I$ thought was the age of the fish. I guessed offland from twelve to fifteen years, and it really appears that I was not fur wrong, for about twelve years ago Sir James Clark's butler put six or eight jack, weighing about a pound and a half each, into Rapley Lake. This great fellow was probably the last of them, who had very likely eaten up all the rest. The fish was a female; the roe weighed threeand-a-half pounds, and contained over forty-three thousand eggs. The only regret $I$ lave is that this freshwater shark was not kept alive and sent to Brighton Aquarium. She should have been tethered by the gills till I came with a carrier for her. That this part of the royal domain is well adapted for growing big pike is evident, inasmuch as not many year's ago a lad who had gone into Inglemere Pond (near Ascot Heath) to bathe was attacked and severely worried by a pike. This pike is undoubtedly the largest in my collection; the two next approaching in size are one from the Norfolk Broads, thirtytwo pounds, and Mr. liooper's celebrated pike, which he was fortunate enough to catch with rod and line in Loch Awe, in 1869. I need hardly say that I and the public in general are much obliged to his Royal Highness Prince Christian for preserving this fish, and enabling me in the interest of science to perpetuate its magnificent proportions and unusual weight. One of the casts of this magnificent fish has been painted to life by Mr. liolfe and presented by him to the Piscatoria? Society, who have had it handsomely mounted. 'The fish is represented as lying on grass and weeds. The duplicate cast is in my Fish Mluseum at South Kensington. I an told that the best bait for a large pike of this lind is the so-called calves'-tail bait. The angler should take about four inches of 
the lower end of the tail of a calf, skin it open, and insert a cork perforated with a bit of gimp; on the end of the gimp nust be attached the ordinary double hooks, which should be properly concealed by the hair on the skin; put a thick boot-lace for a tail, and a cork with two boot buttons for the head. The big pike sees this, thinks it a water-rat, and most likely will come and take it.

Carp, p. 22.-Mr. Charles, fishmonger, of Arabella Row, in 1866 , sent me two very fine carp. The largest weighed $21 \frac{1}{2} \mathrm{lbs}$., was 33 inches long, and $20 \frac{1}{2}$ inches in girth. The smaller fish weighed $16 \frac{1}{2} \mathrm{lbs}$., being 25 inches in length, and 23 inches in girth. They caine from Haarlem Meer, in Holland, and were both fenales.

I lad the opportunity of casting the larger fish, and I also carefully counted her roe which weighed $3 \frac{1}{2} \mathrm{lbs}$. This was done by taking the average of two or three grains, a calculation was then made of the aggregate number of eggss. These amounted to no less than one million three hundred and ten thousand seven hundred and fifty $(1,310,750)$ in this one fish, nearly equal to half the population of London. I also weighed the eggs of the smaller carp, they weighed $5 \frac{1}{2}$ lbs., giving their total number, two millions and fifty-nine thousand seven hundred and fifty-nine $(2,059,759)$. I can guarantee the accuracy of the weighing, and also the calculations, which were made for me by Mr. Thomas, a professional accountant.

Americay Water WeEd,- Since White's time the American Water Weed has appeared. It has done an immense amount of mischief by filling up our rivers, canals, lakes, \&c. Babingtonia damnabilis-or, as it is usually called, $B$. diabolicais a Cambridge name, invented by Mr. Charles Kingsey, for this American water-weed, the proper scientific name of which is Anacharis Alsinastrum, or Elodea Canadensis. The first name was given at the expense of the Professor of Botany at Cambridge, probably under the impression that he had to do with the introduction of the weed into this country, inasmuch as it has been said to have seeded from a piece originally brought to Cambridge by Mr. Babington; but it is generally supposed to owe its introduction to the American timber which is floated down the American rivers aud then brought up our own, bringing with it pieces of the weeds. It was first seen here about 1842, and no doubt came from North America; how, is not known.

It never perfects seeds in England; the sexes are on different plants, and only the female grows in England in enforced celibacy. 
Its vast increase therefore is entirely dne to division; every fragment grows.

WoLMER-Mr. Harting remarks in his edition of White :"The name Wolmer is doubtless a corruption of Wolf mere or Wolvemere; and it is not a little remarkable that the three great meres of that district, Hogmer, Cranmer, and Wolmer, were named after wild animals which are now all extinct in Britain-viz., the hog or wild boar, the crane, and the wolf."

The existence of wolves in England is testified by the story of "Little Red Riding Hood." C. T. W. writes:"Can anyone inform me if the famous wolf, the last of its race in Britain, which was killed by Sir Evan Cameron, in 1680 , and which was prepared as a stuffed specimen, is still extant and in good preservation? I find that in a catalogue of Mr. Donovan's sale of the London Museum, by Mr. King, April, 1818 , one article is (in p. 53, lot 832) a 'wolf, a noble animal, in a large glass case : the last wolf killed in Scotland by Sir E. Cameron." Where can it be now ?" In Ireland, parish registers of the destruction of wolves come down to last century.

Coivs AND Avtiquities, p. 24.-At Barnstaple, in the autımn of 1874, I had the pleasure of meeting Mr. Townshend M. Hall, F.G.S., author of many valuable pamphlets on the geology and antiquities of Barnstaple and its neighbourlood. Mr. Hall's father is rector of the clurch at Pilton, close to Barnstaple.

The Priory of Pilton was one of the most important, as well as one of the most ancient ecclesiastical establishments in the neighbourhood of Barnstaple. It was founded by King Atlielstan, who died A.I. 940, and an impression of the official seal of the priory is still in existence. The inscription on the seal reads as follow :-

IIOC. ATHELSTANUS-AGO. QUOD. PRESENS. SIGNAT. IMAGO.

A few years ago a very interesting and valuable ring was dug up in Pilton Churchyard (it is now in the possession of Mr. J. R. Chanter). Mr. IIall kindly showed me a drawing of it. It meásures one inch and an eighth across. The gold portion of it contains a large sapphire, and around the sapphire on each side there is an inscription. A rivet of gold passes through the sapphire. The inscription on one side is written in Hebrew, and reads thus :-

IMMANUEL JEHI JESU JEHOVAII ELOHIM EL,

which should thus be translated:- "May Jesus Inmanuel, Jehovah, God, be with us." 
On the other side of the ring there is also an inscription, which reads as follows:-

\section{NOBISCUM SIT IHESU ADONAI.}

That is, "Lord Jesus, be with us." This ring was pronounced by the authorities of the British Museum as dating between 1100 and 1130 , or over 700 years ago, and it probably belonged to one of the abbots of Pilton. Returning from Barnstaple, I showed the drawing in my note-book and the inscription to a elergyman who happened to be in the carriage. He, by a curious coincidence, was a Hebrew scholar, and informed me that the word "Jehovah" is considered so sacred that it is never pronounced by the Jews; and that a learned scholar interested in the study of phonetic writing, had ascertained that in this word existed all the sounds which can be made by the human voice as representing language. The word Adouai is used by the Jews for Jehovah. Wherever we see the word "Lord" in our Bible, the Jews read it Adonai.

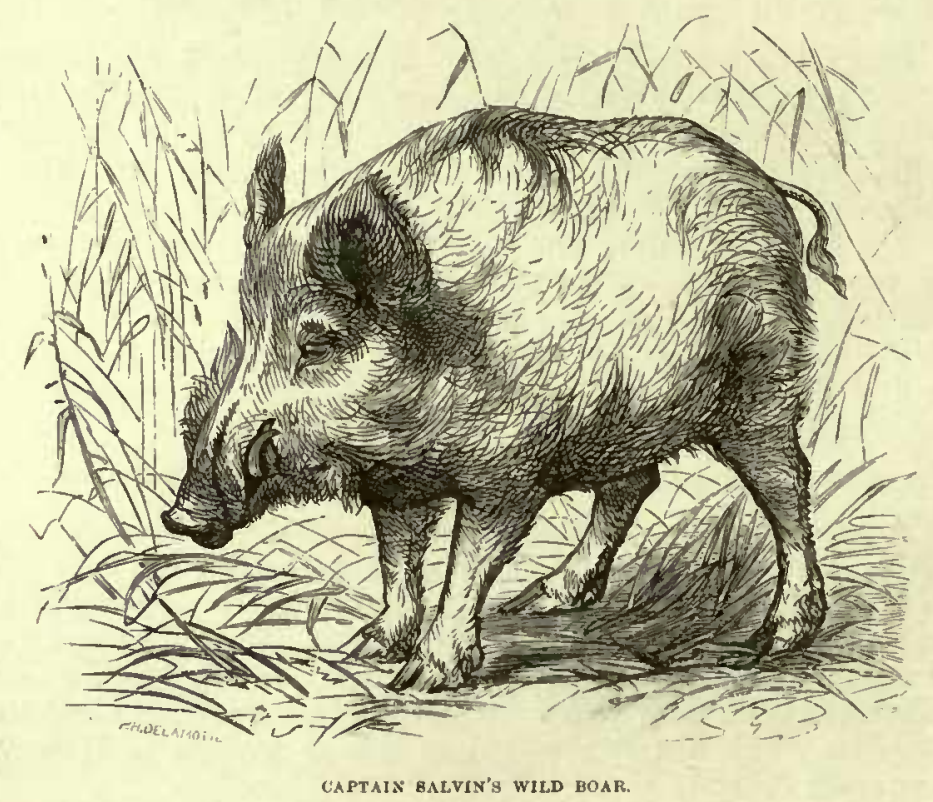

WILD BOAR, p. 26.-Gilbert White, if living, would be very much interested at seeing the wild bons, now residing not far from Selborne. It is the property of my friend, Captain Salvin of 
Whitmoor House, Guildford. Lady Susan-for that is the name of the tame wild boar-is thus described by her kind master:-

"My sow-of whose fighting stray pigs, \&c., I sent you an account some time back-originally came from Syria, and was given to me by H.H. the Mahárajah Duleep Singh about six years ago. She is a remarkably fine healthy animal, and lier instinct and affection ean only be equalled by the dog. She follows me almost daily in my walks like a dog, to the great instonishment of strangers. Of course I only take her out before the crops are up, and too low to injure, cluring the spring and summer months.

"I always have her belled to hear when she is in the woods, Se.; and the bell, which is a good sheep's bell, is fastened round her neck with a strap and a buclile.

"Ifer leaping powers are extraordinary cither over 'water' or 'timber,' indeed only a few wecks since she cleared some palings (between which she lad becn purposely placed to secure her for a time) three feet ten inclics in height. Knowing my pig's exccllent temper, even when she has young pigs, and when domestic sows are always most savacre, I was once guilty of a practical joke. I got a blacksmith who was quite ignorant of even the existence of my pig, to 'come and ring a pig.' 'The styc being under a building he had to enter it at a low door, which was some distance from the sow's yard, where she was feeding. He entered, shutting the door to keep the pig in, and thinking his subject was an ordinary one and that assistants were following him to loold the cord, \&e. He had not been gone a minute, before I heard the greatest 'ruml-ti-tum' at the door', and eries of, 'For goodness' sake, sir, let we out! let me out: I never saw such a beast in my life!' and out came the pool blacksmith, pale with fright, but all the consolation he got was a jolly good laugh at his own expense. From the many places called after the wild boar, as Wild Boar Clough in Cheshire, Branspeth and Brandon in the county of Durham, \&c., it nust lave been very common in Ingland some two or three hundreel years back. Perhaps I may be forgiven if I explain the connection that Branspeth has with the subject: Bran in the north of England means a boar, and no doubt the 'peth' is a colruption of path, hence Branspeth. Brandon was originally Branden, or the den or the lair of the boar, and, curionsly enough, tradition says they were very plentiful in the neighbourhood. Clough signifies a wood along the steep sides of two hills close to each other. The wild boar has long been extinct in the Britisl Islands, but it is common in France, Germany, Italy, the islands of the Mediterranean, Albania, Syria, the north of Africa, and India, VOI. 11 . 
\&c. The wild boar is swift on foot, and is a splendid leaper and swimmer, and never euts his throat in the water. Indeed, that is as much a vulgar error as that birds sleep with their heals under their wing, or that cats suck children's breath. It is generally imagined that pigs are eating roots, when a slovenly farmer, having neglected to have rings put in their snouts, they are seen ploughing up the grass. I linve watched them olten, and I have found that they are then feeding upon the earthworm, and I believe that worms coustitnte a great portion of the food of the pig in its wild state. In Germany they are confined in parks along with deer, and in severe weather food is given them.

"I cannot personally say how long the domestic pig lives. Cuvier and, I think, others say that it has been known to reach twenty years. My tame wild boar sow was fourteen years old, May, 1875, and died a few months afterwards. My domestic pig has had as many as twenty-one pigs at a litter, and fourteen is not uncommon."

Rats AND Mice, p. 32.-In Eugland we have three distinct varieties of rat-the conmon house or barn rat (originally the Norway rat), the old black Euglish rat, now almost extinct, and the water rat or water-vole. The Norwegian rat is said to have been imported in the holds of ships, and to have successfully invaded the territory of his black brother and completely dispossessed him. The common house rat has of late years increased enormously, owing, it is said, to the nse of the steam threshingmachine, which in three days threshes out the wholc stack yard of the farmer, the rats migrating bodily to quieter quarters, unmolested and unnoticed in the general hurrywhereas in former days when each stack was dealt with in detail, and threshed out with the flail, the farmers' men and dogs effected an easy haul of the marauders. In the spring and summer, the house rat uses the river bank and watercourses in common with the water vole, and as he swims and dives well, though he cannot continue long under water he gives rise to much confusion and many errors concerning the two species. Apart from many other distinguishing marks, the coat or fur of the house rat is entircly different from that of the water rat-the fur of the water rat being velvety and long. The water rat, save where he bores throngh water-dams and interferes with drainage, is harmless, living principally on herbage and roots. In Ireland this variety is said to be unkuown, and the only rat ever seen in that country is the common house-rat, which, however, by its numbers quite makes up for the absence of the other. 
In 1875 Mr. Higford Burr of Aldermaston Park, Reading, sent me a white water-rat, a very rare specinen, with this letter:- "I caught our white friend when out fishing. I saw him swimming uncier water, and sank my bait, an artificial minnow, under him. As be swam over it, I jerked it up, and hooked him out.-Frank D. Fowler." This rare beast is the size of an ordinas'y water-vole, only it is perfectly white, and has pink eyes. I sent him to Mr. Bartlett, at the Zoological Gardens. Ile informs me that a white water-rat is very rare. Of course

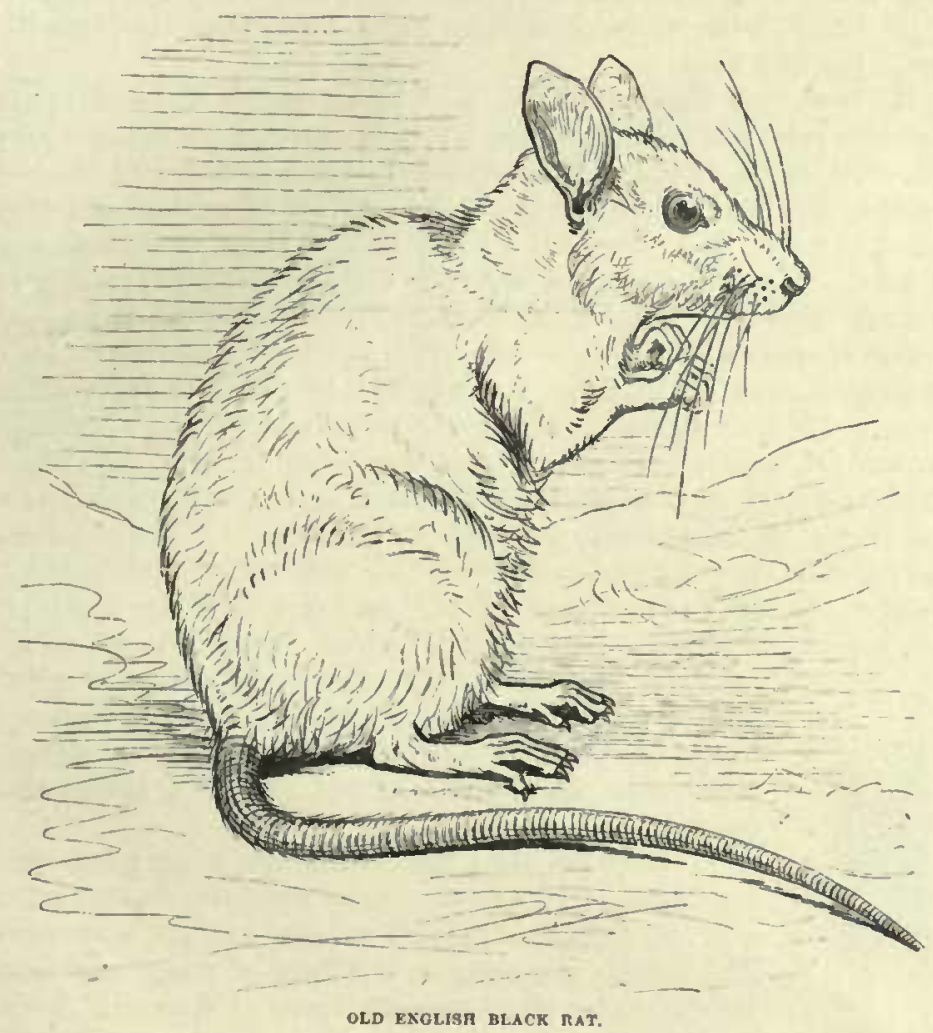

this specimen is an albino water-vole, for a water-rat is very different from a house-rat. White moles are not uncommon, and white house-rats are very common; and I do not see why, in the ordinary course of things, there should not be white watervoles.

Old Britisil Rat.-From time to time I receive specimens of 
the ameient British black rat, whieh is now gradually beeoming extinct. I wonder White does not mention it. It is disappearing gradually before the conumon brown or Norway rat. It is probable that the black British rat was introdueed into this country from France. To this day it is ealled Llygoden Frenzig, (1) the Freneh mouse. The black rat looks like a gentleman as compared with the eommon brown rat. He is mueh slighter in make, lis upper jaw projects further over the lower jaw than it does in the brown rat, his ears are mueh larger and his tail very much longer than in his first cousin, and lastly his colour is a jet black, with numerous long hairs projecting out from the lower fur-like cont.

He is a very timid creature, and rarely shows fight; he is in fact not very powerful, but his want of strength is made up by his excessive activity. The black rat does not frequent drains, cellars, \&c., but rather inhabits the rafters of onthouses: they are said to be still plentiful in the Isle of Dogs, in Jersey, and Bristol. I have deseribed this rat fully in my "Curiosities of Natural History," first series. Bentley, 1874. In 1875 I received "t fine specimen of a black rat. Mr. Searle, my secretary, from feeding lim in his cage for some length of tine in my casting room, got him quite tame. Mr. Searle reports to me that a common brown rat, nearly full grown, was put with him, but the black one being very quarrelsome, the plebeian had to be drowned, as it lad been so constantly worried and bitten. Mr. Delamotte has given a very faithful portrait of this interesting little animal; olserve the silky appearance of his eoat, his delicate attentive ear, his intelligent eye, his long whiskers, by means of which he feels his way alout when out feeding at night, and lis little pinkish white paws (the rat always keeps his paws excessively elean). Fear and danger coustantly surround him, yet he looks happy and contented.

To most people a rat's tail is not a very interesting olject. If however it be carefully examined it will be found to present a very curious structure. The skin is arranged in the form of rings, and from between the rings project rows of fine stiff hairs.

These hairs assist the rat to hold on with his K.TT'S TAII. trit as he is climbing abont rafters, \&e.; he also uses his tail
as a lalancing pole. You will see all this if you set a tame white rat to elimb along a rope.

The following story will illustrate how an elephant can be almost persecuted to death by rats. There is a very fine elephant at the Zoological Gardens at Clifton, near Bristol. 



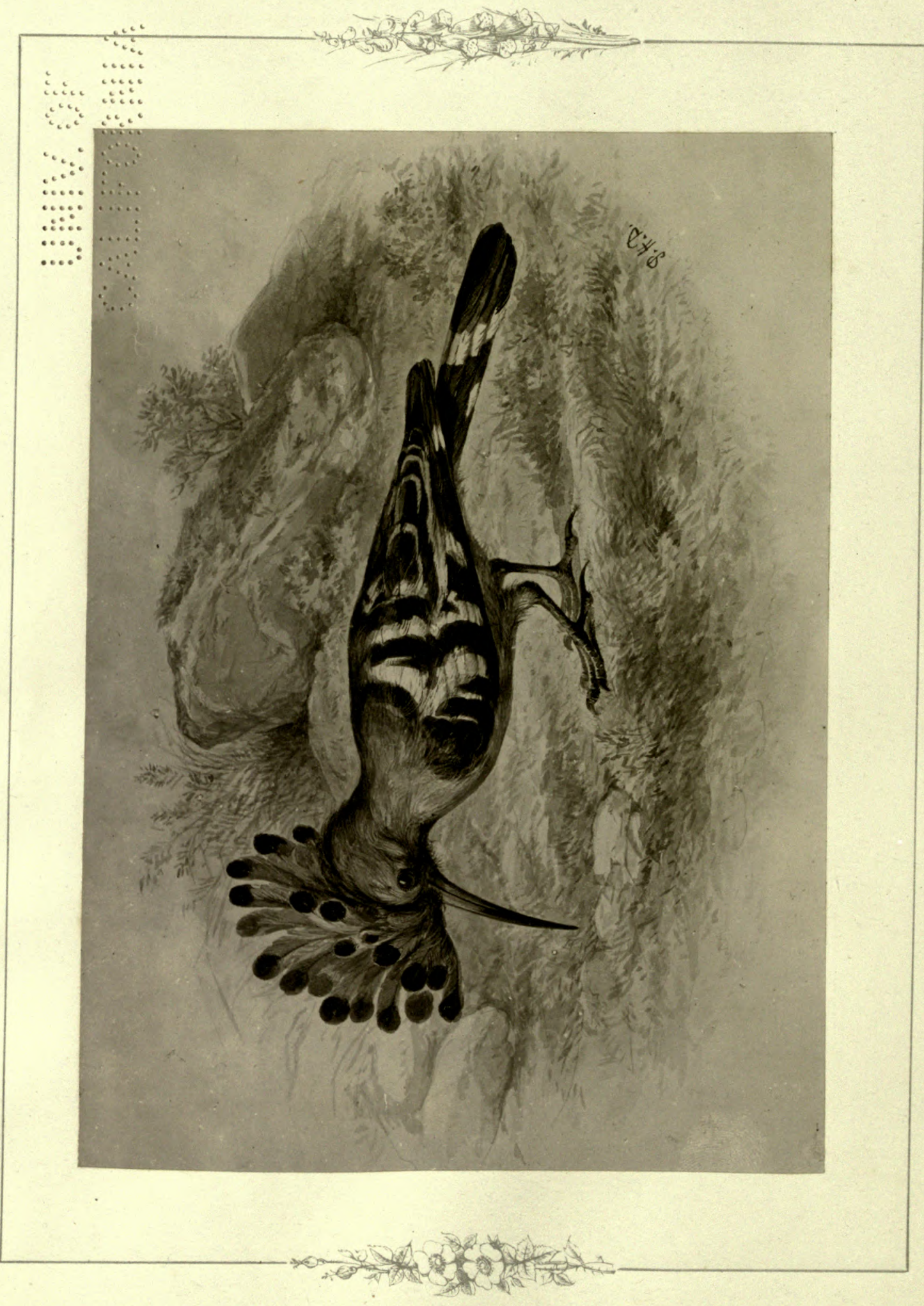

III
0
0
0
0
$I$
$I$
II
$I$
I 
This elephant was found to be very sick and sorry; my friend, Mr. Bartlett, of the Zoological Gardens, London, was sent for to preseribe. The animal was walked out for him to examine. Mr. Bartlett desired the keeper to make the elephant show her feet; when the animal lifted up her feet, they were found to be gnawed into holes by rats. The rats were very abundant in the elephant house, and when she had lnin down to sleep they had eaten the gristly portion of her feet away. The rats were destroved and the elephant put into a new house, where slee is now well and thriving. The poor elephant had been suffering not only from the wounds in her feet, but also from want of sleep, as the rats kept her awake all night by their persecutions.

Hoopok, p. 35.-The name "Hoopoe" is from French huppé, tufted. In Italy it is called bubela, from its cry "bu bu bu." It is not an uncommon bird in Spain, aud is abundant in Egypt and Arabia. Whereas Stanley, on Birds, tells us the hoopoe is called the ehild of Solomoll, from the tradition that the hoopoe formed part of the crigo of the ships of Tarshish. The tradition of the people whence the hoopoe was brought was that its erest was at first of gold, but that, owing to man's cupidity for the precions inetal, the birds were killed for their crowns; they therefore met and petitioned Solomon to ameliorate their condition, and as he understood the language of animals, he put up his prayers that the crown of gold inight lienceforth be changed to a crown ol leathers. The change was instantly made to the present lovely erest witls which the hoopoe is now adorned. What a beautiful subject for the poet:

Mr. Davy informs me that lately two of these birds were shot on the bank of the Midland Railway, in the neighbourhood of Hampstend, in Gospel Oak field ; if not so cruelly shot at they would stop and breed. They are very tame birds, and being very showy nre easily detected. They feed on small fool on the ground, on caterpillars, worms, and small beetles. Mr. Davy had one in his shop for two years-it had been crippled. It was i very ravenous bird, would eat any animal or vegetable matter-preferring animal-never feeds on trees. I find it runs and feeds much alter the manner of the starling. The loopoes would probnbly stay out the summer with us if they were not so perseented. When tame it is a very funny bird, and when it fints up its crest a very beautiful bird.

Crossbius, p. 35.-Crossbills are rare in Britain. Their song 
is very soft. In severe winters they are found sometimes in numbers close to London; there were some in Highgatc Cemetery last year and the year before; they feed on a species of fir-cones growing in the cemetery. When some fir-trees were cut down near Weybridge, several old nests of crosshills were found in them; it is rare to get the young; they breed in the Hartz Mountains; they are very fond of the horn-bean seed, which seeds before leafing. They are remarkably tame birds.

Eels, p. 35.- How to Catcir Eels. - In the autumn floods the eels descend in vast numbers to the sea. They rum best on stormy nights, especially when there is thunder about. I have heard a story of an old fisherman who lived by his eeltrap. The eels would not run freely, so he got a drum and sat up all night tapping upon it. When asked what he was doing, he replied that he was playing the drum to make the eels helieve it was thunder.

F. Poole writes me:- "The following dodge may be useful to many gentlemen who own large ponds. A simple way to catch eels is to take a corn-sack, turn down a hem, and run a line round at the mouth. Drop a sheep's paunch into the sack, and fill up with straw as tight as possible. Sink it in the pond or river. The eels work through the straw to the end. By drawing the sack up by the cord, it is closed, and you have your eels bagged."

Another good plan is to put a large barrel under the fall which takes off the overflow from the pond in the autumn-time, when the eels are migrating. Bore plenty of sinall holes in the tub-these will let the water go out, but not the ecls.

The largest eels in my collection (casts, of course) are Tewkesbury, 7 lbs.. Yarmouth, 7lbs. and 6lbs. Serpentine London, $6 \mathrm{lbs}$.

Statues at Oxforn, p. 36.-My father's museum of geology was formerly situated in the Clarendon Buildings, close to the Thentre, where the Commemoration of founders and benefactors is held. Upon the top of this building there are figures of the Muses cast in lead. I find the following interesting verses in reference to these in a book called "Strephon's Ievenge: a Satire on the Oxford Toasts," written in the reign of George I., 1718. The author, after bewailing the bad poetry written in those days, writes-

"Nor is it strange, but rightly weigh the thing,

That our soft bards so indolently sing,

Or that the genius of the place is dead,

When our inspiring Muses breathe in lead: 
High on the stately dome, with harp in hand,

Their lumpish deities exalterl stand,

Fixed as a public mark, that all might know,

What wretched heavy stuff they print below."

Pigeons at OXFond.-I was born and brought up at Christ Church, Oxford. When my Father took us to church on a Sunday morning we always saw many pigeons at Carfax, where the four cross-roads meet. "ithere were never any pigeons at Carfax except ou Sunday morning - none on a week-day. My father made ns observe why the pigeons only cane of a Sunday. The reason is that it is the custom of the farmers to meet at Carfax on Saturday and show samples of wheat to each other. The pigeons carne on a Sunday morning to pick up the spilt grains.

Bats, p. 36.-A Tame Bat from Bruges Cathedral.-My friend, Mr. Samuel Walker, thus describes his tame bat, Piggy:"During a tour in Belgium, in 1874, we ascended the high belfry at Bruges, and while exanining the bells my attention was drawn to a bat flying about. After half an hour's chase, I captured him and carried him off in my handkerchief. The little creature did its best to bite me, and on returning home I constructed a wire cage, in which it lived (or nearly died) for nine days. On my arriva! in London I at once took it to Mr. Frank Buckland, who was charmed with my prize, and at once prescribed warmth, water, and meal-worns. Until his suggestions the little creature lad been left in draughts and fed with flies and meal-wornıs. Mr. Buckland called to see it, and praised the new cage I had made for it, i.e., a box a foot square, lined with green baize, perforated zinc at the top, glass in the front, and a door at the back. ' 'Ijggy,' for that is the nanne we have given it, is now in good health, eats eight meal-worms daily, bosides daddy-longlegs, of which lie is very fond, and after he has eaten them smacks his lips and yawns. It frequently opens its mouth as if thirsty, and I immediately give it some water at the end of my finger. If I give it too mmch it squeaks like a mouse and tries to bite me. The size of the bat when asleep is not larger than an ordinary monse. When flying it measures about eight inches from wing to wing. Inside the cage I put two sinall bottles with warm water. After a good meal it purrs louder than a cat, in comparison to its size, and if I stroke it gently it erects its cars, and puts first one and then the other up to be scratched. It has a coat about an eighth of an inch thick. Its habits are eleanly, and its manners finny." Piggy lived about five months, when he died. I cast him and painted him to life. 
Bats in Churches. - The following is a preseription which will be of use to country elergymen who are plagued with bats in their churches. "I ean inform a brother elergyman that I have succeeded in keeping bats out of my chureh by stuffing bits of gorse or furze into the small recesses where they take up their quarters. The same remedy applies in the ense of sowing peas; if they are covered with small sprigs of furze. the prickles will prevent their being attacked by mice. I am now applying it also as a means of keeping slugs from youner plants of dahlias."

Mouse Caugiht by an Oyster, p. 37.-I have in my museum at South Kensington, preserved in spirits, an excellent specimen of a mouse caught by an oyster. When oysters are exposed to the air any length of time, especially in hot weather, they always " gape their shell ;" probably seeking for a drink of

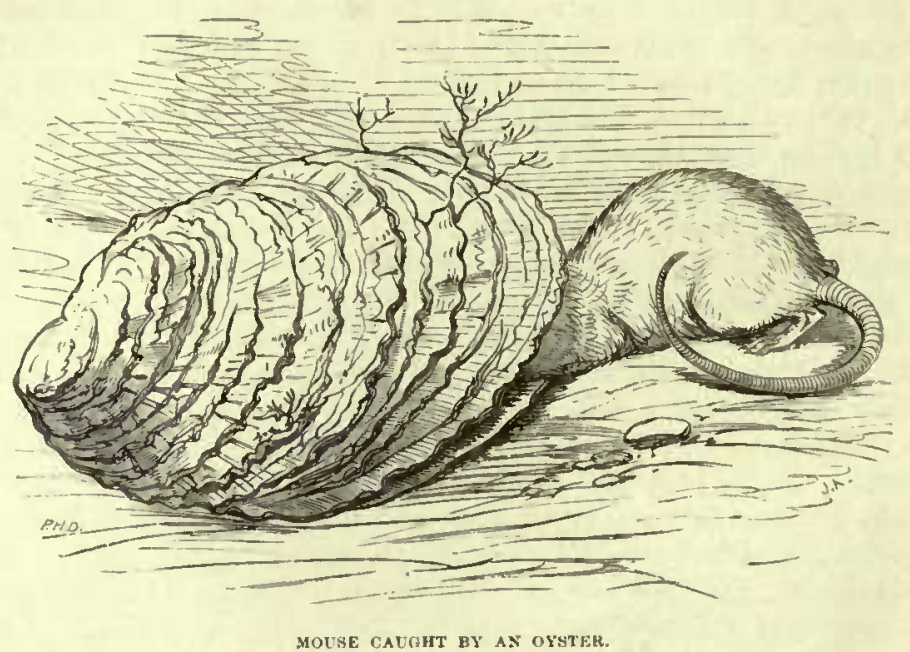

water. The beard at this time lies flat upon the shell. In the ease portrayed in the picture the oyster must have been placed without water, in a larder. The mouse hunting about for food put his head in to nibble at the oyster and was trapped. A second specimen of the same oceurrence was sent me in August, 1875. In both cases the mouse was killed by the pressure of the oyster's shells. The adductor musele which works the shells of the oyster is very strong. The oyster that canght the mouse is very handsome; the points of a good oyster 
are, first, a ehina-like shell, and second, a deep upper shell to contain the meat. The mouse in the picture must have been a judge of oysters. I liave also a photograph of an oyster-catcher being caught by the beak by an oyster, and I once lad a specimen of a crab that had been caught by the tip of the toe by an oyster. People at the sea-side should be very careful not to put their hands into holes to bring up lobster's and crabs. I have heard of a case of a man's fingers being nipped by the crab's claws and his hand jammed in a crevice of the rock, until the tide rose and drowned lim.

YEws, p. 38.-The juice of Yew berries is good to eat; the seeds are dangerous. The boughs are fatal to cattle, though it is not often cattle will meddle with them except from mischief or idleness. Cattle and deer seem to prefer the boughs or loppings of yew, laurel, and other evergreens, when they have been cut a few days, and are much more inclined to eat them in that state, than to browse on them as they grow. Gardeners and foresters cannot therefore be too careful as to where they throw refuse of this description.

Haws are a very favourite food of many hirds, and a good crop of these berries will bring into the neighbourhood humdreds and hundreds of field-fares and redwings. Even black game will come down from their customary haunts to feed on the road-side hedges; and an old blackcock picking haws alongside the Queen's highway has not unfrequently astonished the wayfarer.

Canaries, p. 40.-It is quite possible to breed canaries out of doors; the eggs should be placed in the nests of ehaffinches or greenfinches, those of greenfinches would be preferable.

The cross (artifieially produced) between the cock greenfinch and hen canary is common.

Mr. Davy has received from Norwich canaries bred out of doors in aviaries; but they are, as a rule, of a pale colour to those bred in eages indoors, and consequently are more wild for the first few days.

During the winter these birds are so much exposed that the ice lias to be broken for them to drink.

My friend, Mr. Monk, of Lewes, informs me some wild canaries were taken at Southwick, near Brighton, in April, 1869, feeding with a party of linnets, and as they showed no marks of having been caged, he surmised they might liave migrated here.

I learn from Mr. Davy that there is no putting a cauary's song into words, but a canary may be taught any VOL. II. 
bird's song by being brought up from the nest among them. As regards the canary market in England, the great breeding places are Norwich, Yarmouth, Yorkshire, Leicester, and Manchester. These places supply the London market with canaries. Canaries are mostly bred by shoemakers during the summer, and sold to the London trade from October till March. They are sent up in "scores," one score being twenty pairs. If you were to send for a "score" of canaries, they would send you forty birds. The breeders prefer sending them in pairs. Three hens are charged as a "pair." The wholesale price in the autumn is $\mathbb{E} 4$ per score. The price rises in the spring, and advances to as much as $\mathfrak{f 7}$ per score.

The most valuable and delicate canaries are the Belgians. When undisturbed they sit "all of a lump," but when the cage is taken down they show their beauty by lengthening themselves out like a telescope, and bringing themselves into form. Some will nearly pass through a large wedding ring, and bircls of first-class will fetch as much as $£ 10$ per pair. The kind of canary most resembling the Belgians are the Yorkshire birds. These are also very long and graceful. They vary from $7 s .6 \mathrm{~d}$. to $30 \mathrm{~s}$. per pair. Norwich, as a rule, produces the richest coloured lirds. The motto is :-

$$
\begin{aligned}
& \text { Norwich for colour, } \\
& \text { Belgiun for shape, } \\
& \text { And German for song. }
\end{aligned}
$$

The best come from the Hartz Mountains. German birds are not much to look at, but command high prices on account of their beautiful song.

Chaffinches, p. 41.-The Iondon bird-catchers take great numbers of cock chaffinches by dummies. A duminy is a stuffed finch, fastened on a peg, which can be placed on a fence or on a tree by means of a small sharpened wire on the end of the peg; bird-lime twigs are placed under and above the dummy. The birds are attracted by the song of a call bird in a cage, which is placed or hidden in a ditch close by. The wild bird, thinking that the dummy is singing, comes down to attack it by striking at it; the feathers of the wild bird get caught by the bird-line and bird and twig fall to the ground. This plan can only be carried out when birds are in full song, when they are "off song " they will not strike at the dummy. The wild bird thinks the dummy is a poacher on his beat.

There are four or five different ways of putting the chaffinch's song into words. Thus one bird sings, "Ring, ring, rattle, chuck wido ;" a good "chuck wido," is considered the best song 
bird; again, another bird sings, "Ring, ring, rattle, Jack white."

The poor Spitalfields weavers will give $3 l$. or $4 l$. each for a good chaffinch. These birds are sung in inatches for from $1 l$. to $5 l$. ; many bird-fanciers will come for miles to hear a good chaffinch. Most of the matehes are sung by gaslight. Two birds are put up at a time in separate eagres to sing a match; fifteen minutes is the time allowed for the singing match, and the bird who does the greatest number of complete songs in that time becomes the winner. Some birds are called "Chuck wido" birds, some "Jack white," and some "Kiss me dear," from the finishing words of the ehaffinch's song. The best song birds are to be found in Essex. The average price to a shopkeeper is $3 \mathrm{~s}$. a dozen. Some turn out good birds, some bad, you are as likely to get a good bird for $6 d$. as a bad one for $1 s$.

The greater portion of these finches are "sighted," or as they call it, "done;" the cormer of the eye is slightly tonched with " red-hot needle, and the injury is scarcely discernible. They are kept in little square cages till they can find their food and water before they are "done." It is a most eruel practice. The Anti-Cruelty Society should look to this and stop it at once.

Chaffinches remain upon the stubble all the winter till they are ploughed out, and move to other localities for fooll. When driven by snow they abound about stackyards. They are decidedly migratory ; a larger kind and brighter coloured chaffinch comes from the north and returns in the spring. Mr. Davy has seen the same kind of birds in eages from Germany. London fanciers do not like them; for their song, as a rule, is indifferent.

Large flocks of chaffinches come in the September and October. flights. Most bird-catchers catch equal numbers of males and females. They are to be found upon the stubble fields and freshly manured ground, and on long litter, until pairing time in spring.

LiNNETS, p. 41.-Linnets come from abroad in immense flocks, and locate themselves on stubble where charlock seed abounds; when spring arrives they go away in flights to their building places. They are taken in elap-nets by thousands, as are the chaffinches.

The song of the linnet is thus put into words by the Loncton bird-catehers :-

" Hepe, hepe, hepe, hepe

Tollaky, tollaky, quakey, wheet,

Heep, pipe, chow,

Heep, tollaky, quakey, wheet,

Lug, orcher wheet." 
The toy-linnet is a bird that has been taught to sing by the titlark, woodlark, or yellow-hammer, and only a very few take the perfect song. The following is the perfect song of the toylimnet. It begins thus:-

" $\mathrm{Pu}$ poy, tollick, tollick, eky quak,

E-wheet, tollick, cha eyk, quake, wheet."

This is one stave of the song. The next staves are:-

"Phillip, cha eke, quake, wheet,

Call up, cha eke, quake, wheet.

Tollick, eke, quake, clow,

Eke, eke, eke, quak chow.

Cluck cluck, chay, ter wheet tollick, eke quake, wheet,

Echup, echup, pipe, chow.

Ah, ah, all ! J-o-e,

Eke, quake, chow, rattle.

Tuck, tuck, wizzy, ter wheet,

Tolliky, quake wheet."

This is the finish of the toy-linnet's song. Perfect toy-linnets are worth any sum of money you like to ask-15l. to $20 l$. would be given readily for a thorough good one. "Broken song" birds are only worth $30 \mathrm{~s}$. to $50 \mathrm{~s}$. each. A broken song-bird will not make his stops in the song as given above; he wili run one into the other. The old song-birds (linnets) are very scarce, as the trainers of then are gradually getting old and dying off. When the above song is put together by a proper bird, lie does it just like a flute; it is something splendid. It is said that there is not a perfect bird in London at the present time.

To get these birds to learn the song they must be taken from the nest very young, before they get the call of the parent birds.

SNow-Bunting, p. 42.-The common snow-bunting is plentiful in the autumn around the Norfolk coast, particularly at Yarmouth; it is a very hardy bird, feeds frecly on oats and any kind of seed. When on flight they are often taken by the ordinary observer to be pied-larks. The old birds are very light, nearly white, and not worth keeping for song, only for aviaries.

"Snow-flakes" are snow-buntings, and arrive in this country in great flocks, about the Norfolk coast particularly. Formerly they were rare, but now the bird-catchers keep call-birds of the same species all the year round, so that the snow-buntings are now very plentiful in the bird-shops in the autumn and early spring. They were taken in abundance at Brighton last year. They are killed and eaten as larks. 
WagTaIL.S, p. 42.-There are four different kinds of wagtails. 1st. The white wagtail arrives in this country in the beginning of March, and breeds mostly in old barns, and departs in small flights in the niddle of September. 2nd. The pied wagtail. This bird never leaves this country; it is very common, and breeds near brooks. 3rd. The grey or dun wagtail. This breeds in Scotland, on the moors. They are caught round London from the end of October to the spring. These birds are very rare; tbey frequent brooks and ditehes all the winter, and do not breed here. 4th. 'The yellow, or Ray's wagtail, breeds on poor land; arrives in April and leaves in the middle of September. The four species are found all over England; they are easily kept in confinement; they have a short song, or rather eall; they sing during the breeding-time.

The wagtails have different calls. The call of the black-andwhite wastail is "Physic, physic, physic," quickly repeated: with a whistle Davy can make them come close up. Listen to the first wagtail you hear, and you will find he invokes the aid of the medical profession.

Pied wagtails are good fighters. "Cornubia" remarks, "During the severe weather the daughters of a friend of mine, with praiseworthy bumanity, ministered to the wants of the various birds morning and evening. Robins, house and hedge-sparrows, blackbirds, tits, finches, wrens, and others, came punctually to their bidaily banquet; lut there was one amongst them quite a monsterof selfishness and tyranny, who made all others fly at his approach, and he was none other than a pied wegtail (Motacilla Yarrelli). One would have expected to see the plucky cock-sparrow, or pugnacious robin at least, resent the tyranny of M. Yarrelli."

Wheatear, p. 43.-The Wheatear arrives very early in the spring, and abounds particularly on the south downs. After recovering themselves, they make inland to their breeding places. Wiltshire is a favourite locality. They are, without a doubt, a migratory bird, and one of the earliest visitors to this country: they are frequently caught the first week in March. The trap used to catch them is the common nightiugale trap. They are very easily caught; the best bait is a meal-worm; they are splendid eating. They are sold in large numbers in Irighton; they are best and fattest in the beginning of April.

Stoats AND Weasels, p. 47.--Stoats and Weasels, two distinct species, are frequently confounded together, and the small female stoat and large male weasel occasion much controversy. How- 
ever there is one distinguishing mark which may always set any question as to species at rest; it is that the stoat always has a black tip to its tail, and the weasel never.

From its size and strength the stoat is far more formidable than the weasel, but, with the exception that the latter turns his attention a good deal to mice and moles, to which the stoat seldom condescends, their ravages are very similar.

In our islands the stoat retains the same coat winter and summer, except in the north, where it is said occasionally in hard winters to assume a white or ermine garb.

Very often stoats and weasels attack Mr. Davy's call and "brace birds" when he is out bird-catcling. They always seize them by the head. The weasel will get through the ordinary water-pot hole of a bird-cage; he will get through any hole that will pass his head. A tame weasel is a very amusing creature.

Rooks, p. 47.-Mr. Sawyer, of Richmond Park, writes:"The best thing I have ever found to keep rooks off, is thin string tied from stick to stick across the field in various directions."

White rooks are not uncommon. A few white and creamcoloured starlings are seen every year; if the eye is black, the white starling, after moulting, will come to its proper colour, but if it has a pink eye, it will become white and, as a rule, will have flesh-coloured legs.

Bullfincues, p. 48.-Mr. Davy writes:-

"Black bullfinches by some persons are thought a great rarity, but not so with my bird-catchers; for when a bird moults out of colour, as a rule, it loses its natural hoop or call; it is then of course, of no use as a call-bird. The reason of its becoming black is overfeeding with hempseed, which causes weakness in moulting. A bird once black, either cock or hen, may, by breaking off this food by degrees, and feeding on summer rape and callary, be brought to its natural colour in the next moult-give plenty of green food also. I know of one cock bullfinch, now in good health, that has been worked out catching, almost daily, nine months in the year; it is in beautiful plumage, and is liept in a very small cage. This bird has plenty of henı among its ordinary seed, but by being continually exposed to the fresh air in different parts of the country, and constantly getting a ducking with rain, the seed does not affect the plumage. The above call or decoy-bird was four years old in June last; it lias been the means during its career of causing the entrapping by nets and birdlime of not less than from 300 to 400 birds. 
"Too much hempseed will turn black the plumage of bullfinches, thrushes, skylarks, and goldfinches; it will change the plumage of most birds ; they will get procligiously fat on it."

The bullfinch is said to be very destructive to buds of fruittrees. The case oughit to be fairly put: he does good also, inasmuch as he prunes the trees; he knocks off a great many good buds, thereby causing those which remain to be more vigorous and fruitful ; in fact, he is a practical gardener, aud by his pruning operations does more good than harm - if he does any harm at all.

LARKs, p. 48.-Skylarks are very common all over England; immense flights arrive annually in October from the north. The birds that then arrive are much darker in colour and much larger than our native birds. Mr. Davy has had larks, a hundredweight at $n$ time in hampers, which have been caught on the hills between Newmarket and Cambridge. They are canght in tranmel mets, at night, and are killed as they are caught, both males and females, as there is no sale for them during November and December. As spriug advances, the cocks increase in value to bird-fanciers, the hens then are alone sent to the poulterers. The wholesale price obtained by the bird-eatchers is about $9 s$. a gross, or $9 d$. per dozen; sometimes they will fetch $2 s$. a dozen. The lark trammellers cannot work of a bright moonlight night; and the birds cannot be well caught on rainy nights, as the vets are then too heavy. At times of snow they are caught by springes, i.e., horsehair nooses tied on to a striug. 'The best bait is black oats sprinkled along the line of springes; they are generally caught by the liead, leg, or wing. 'The Jarger lasks are called Scotch larks, they are never caught after the end of February.

Some time since were landed at Folkestone, from Boulogne, a large quantity of larks, weighing about seven hundredweight, all of which had been snared by the leg with horsehaira very common practice on the Contivent during snowy weather. I find, on sending to my poulterer for some larks, that twelve weigh one pound, therefore, in the seven hundredweight sent through Folkestone, there were no less than 784 dozens, or 9,408 individuál larks. At $2 d$. each, the value of these birds anounted to $78 l$. $8 s$. in money. These Frenchmen go out "larking" with good reason.

Chiff-Chaft, p. 49.-The bird of the Salicaria lind mentioned by White was probably the chiff-chaff. This bird is the earliest and merriest springr singing bird we have got. It hangs about leafless trees, arriving often at the end of February; it is very lively. 
The chiff-chaff is also called the "chinky-chank;" its only song is chiff-chaff. It is the earliest migratory bird that arrives, and stays very late, even to the end of November. The nale bird is brighter in colour than the female. This little birl has been seen by Mr. Bartlett at the Zoological Gardens as early as March.

NuT-HATCH, p. 50.-The Nut-hateh makes a very amusing pet if reared from the nest, and becomes perfectly tame; he is always on the move, climbing up the sides of the trees and tapping for insects, \&c. The nut-hatch takes possession of an old hole made by the woodpecker, and stops up the hole with mud, lenving an aperture just big enough to get in and out. This curious doorway is scarcely perceptible to the eye, as the mud corresponds with the colour of the tree; he builds from four to twelve feet high from the ground; if he cannot find a woodpecker's hole, he will take any other.

The nut-hatcli's foot is made for climbing, but he cannot hold anything by the foot. When he cannot get beech-nuts, \&c., he will eat all kinds of insect food, he will also eat oleaginons seeds. Mr. Davy thinks they will hicle away beech-mast and nuts for winter eonsumption. They are canght under beech-trees and in groves of old limes or chestnuts. They make their nests in the old holes which the spotted woodpecker has dug out. All woodpeckers make holes in the trees and then tunnel downwards about a foot. They carry the chips away as they dig thein out.

WILLOW-Wrens, p. 51.-No doubt the three willow-wrens mentioned are mistaken for the chiff-chaff, wood-wren, and willow-wren, the wood-wren being very rare; the legs of the willow-wren are flesh coloured; the chiff-chaff is smaller, and the legs are nearly black.

Grasshopper Warbler, p. 52.-The grasshopper warbler is a very sliy bird, something like the whitethroat; makes its mest on the ground; comes late, abont A pril, and goes away in September. It is entirely an insect-feeder. The song is deceiving, and resembles the eroaking of the grasshopper or locust; it shifts about a great deal when singing. Most of the woods round London produce two or three pairs in a season. They prefer quiet woods, and sing on the lowest twigs of bushes. 'Tlis bird is hard to keep in a cage ; the longest time ever known is seven weeks. It requires soft insect food, such as small hairless caterpillars. None of the bird-catchers have ever seen it migrate; 


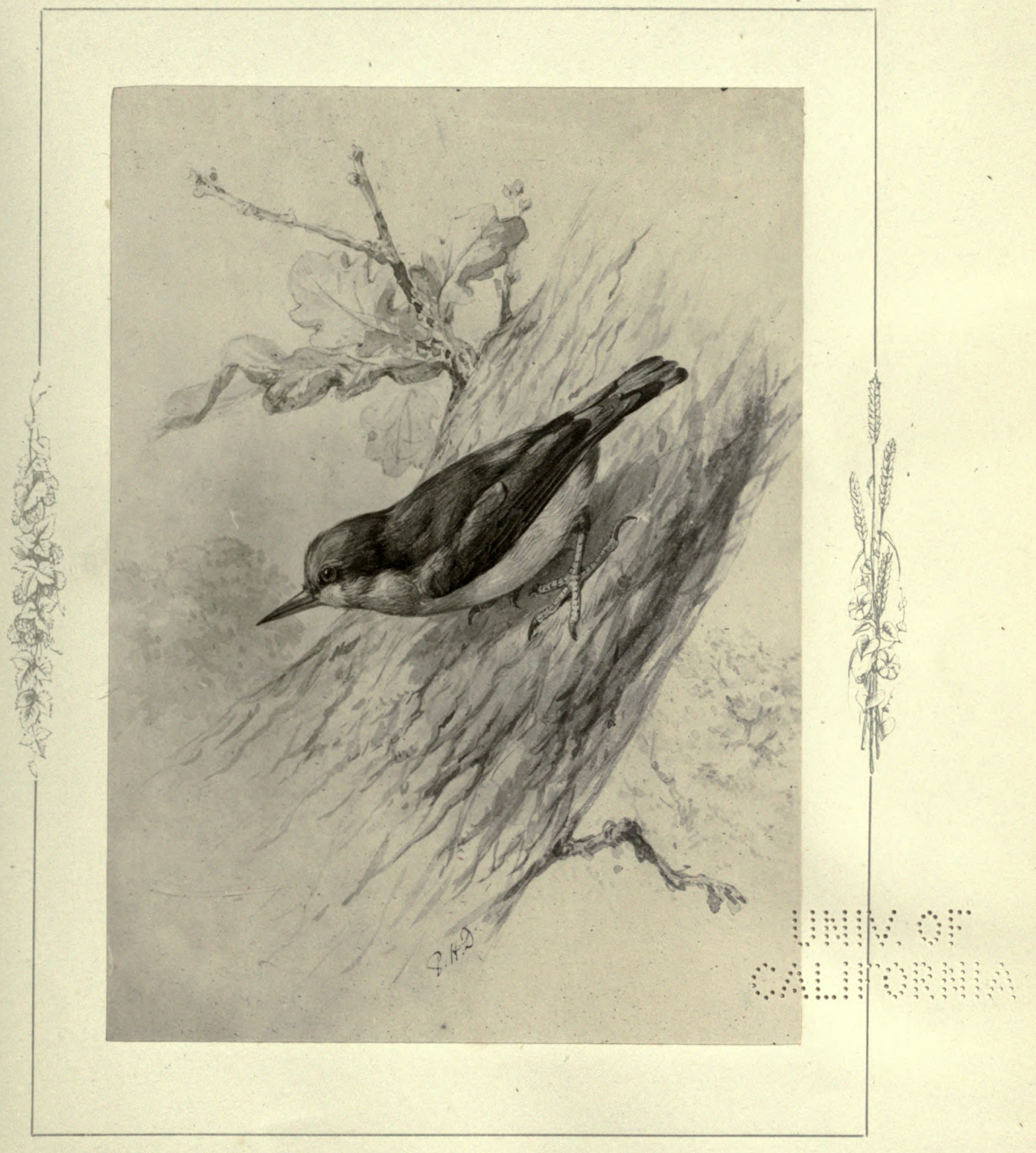

THE NUTHATCH. 


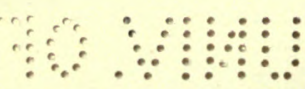

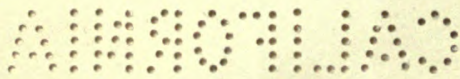


it is here to-day and off to-morrow; lut disappears in the beginning of September. Mr. Bartlett informs me that the mouths of the young of fruit-eating warblers are pink or flesh-coloured; the young of the insect-eating warblers, on the contrary, have the inside of their mouths yellow.

Golden-Crested Pegulus, p. 53.-Mr. G. Napier writes:-

"The golden-crested regulus (Regulus eristatus) is a constant resident in Pritain. It forms a compact nest of moss, which in texture resembles that of the finch's. It is often adorned with lichens, as well as bound together with spiders' webs, and the inside is lined with feathers. One nest I possess has a turkey feather as a valve or trap-door cunningly placed by the bird at the entrance of the nest. This bird usually suspends its nest from a branch of an overlianging yew or fir-tree. It is of a pork-pie shape; I have one as open as a chaffinch's. The eggs are most commonly of a nearly uniform pale yellow buff, but some have a white ground, with spots of dark purple and dark red; others are very nearly white, like sorme varieties of the eggs of the long-tailed tit.

"The nest of the wood-wren (R. sibilatrix) is a dome sturucture, the entrance to which is usually from the side. In shape it resembles that of the dipper, for it has a flattened appearance; it is made of the stems of the bedstraw intermixed with grass, moss, and dead leaves. The lining in both the nests I have is of grass; but sometimes horsehair is used. The ground colour of the egg is white or yellowish white, with spots of ash-blue and umber distinctly clefined, and scattered all over. Some have a zone of spots towards the large end, but in others the spots are equally distributed."

Toads, Frogs, AND Neiv's, p. 54.-The ponds in the brickfields about London produce toads and frogs in great quantities. The only sale for frogs and snakes is at the Zoological Gardeus, where they are used for feeding purposes. The market price of frogs averages $6 d$. per dozen.

The new snake-eating snake, Optiophagus elaps, a kind of cobra from India, is raising the price of common suakes in the market. He has devoured no less than eighty-two common snakes between March and November.

I do not believe in the "shower of frogs" story.

When frogs get "legged," from beiug loggerheads or tadpoles, they are wonderfully migratory things, like eels, always on the move. A very remarkable plague of frogs occurred on the flat lands near Windsor in June 1875.

VOL. JI. 
The legend of toads curing people of cancer and other complaints, says Mr. Davy, is all "Old Mother Hubbard." A hundred years ago people used to make a living by quackery of all sorts, and servants and farm-labourers used to put about that they had been "cured by a toad." Even in our time there is always some quack doctor about who says he can cure cancer. I am afraid this is impossible.

The cancer-doctor of White's time had evidently set up toads as a remedy for this disease. At my father's rectory, near Islip, a woman once gave her child a half-grown frog to suck, as she had been told it would cure the tbrush round the child's inouth. It is astonishing how these old relics of wonderful cures remain in the recollection of country peoplc. When with the 2 nd Iife Guards at Aldershot I heard the story of a man having been cured of some disease-fits, I think-by moss taken from the skull of a highwayman, whose skeleton had been for many years hanging in cliains on a hill near the camp.

Newts are often dug out at places one mile from water. They are fonnd ten inches down in the ground. They are found by men when chrysalis-digging round roots of trees and along sides of old walls; this is where the best chrysalis hunting-ground is situated. Mr. Davy can discover the haunts of caterpillars where there is clear ground underneath the tree, by looking for the excrement which has fallen from the trees; he then shalies off the caterpillars. Some caterpillars are fetched down by the first sudden jerk; some, on the contrary, will hold the tighter after the first jerk; some "web up" and come into fly the same year; some burrow in the ground till the next spring.

Frog Cultuke, p. 54.-An Anerican pisciculturist proposes that some enterprising persons shouid turn their attention to frogculture; and he gives careful directions for procuring and treating the spawn of frogs. The spawn will hatch in about fifteen days, and if the tadpoles and young frogs are placed in a snitable position, they nuay be easily reared, and a large profit made. The mode of feeding the frogs is, to place pieces of meat, or other substances, to attract the flies, upon which the frogs feed; they will also eat maggots of decayed meat, and even the meat itself. It appears that the demand for frogs in. America is increasing, and in that case a frog-farm might be made a good investment.

The Americans have it that when the bull-frogs croak the gentlemen frogs sit on a log and say " Mole rum;" the Lady frous croak 'Cider too.' If the reader will pronounce these words very 
quickly, he will find that an idea of the croaking of frogs is obtained.

Svakes' Egas, p. 57.-The engraving below shows the eggs of the common snake just ready to hatch out. I found them in a dunghill in Aldermaston Park, Reading, when on a visit to my hospitable and kind friend, Higford Burr. I have thus described them in my "Log-Book of a Fisherman and Zoologist:"-"Lifting up the straw most carefully, I was delighted to find first one, then two, then a dozen eggs. The squire and I then proceeded leisurely to dissect out the nest with our pocket-knives and a dung-fork.

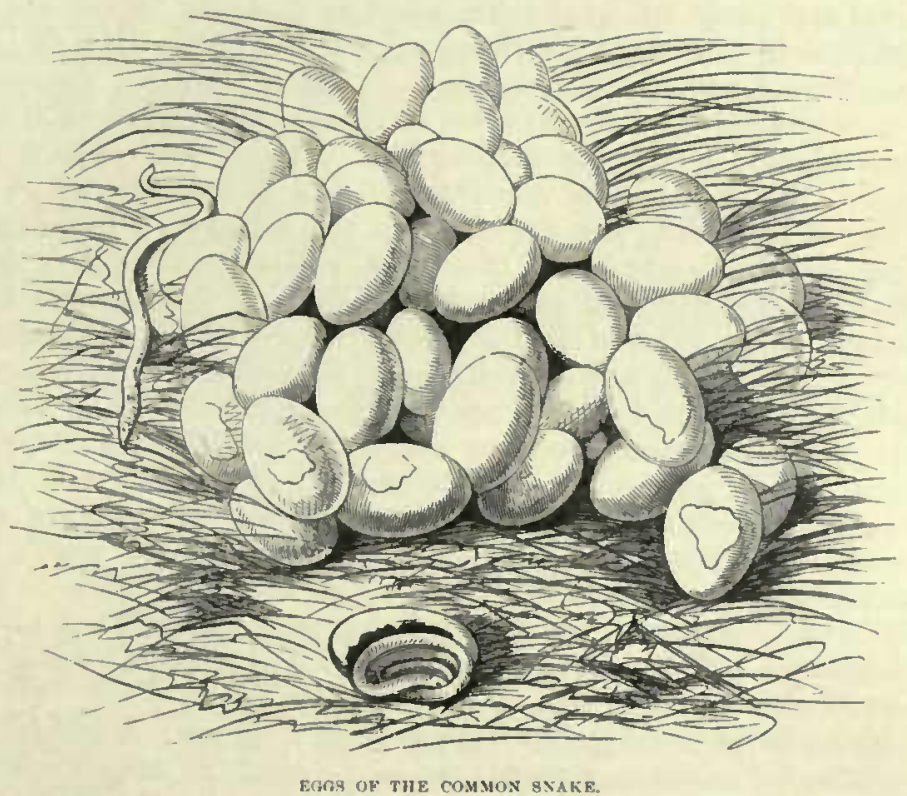

Snakes' eggs are not quite so large as a blackbird's; they are round at both ends like a sugar-plum. They have no hard shell like a hen's egg, but the shell is composed of a soft elastic substance, like thin wash-leather. Some of the eggs were lying quite separate. The greater part were, however, stuck firmly together, so tightly that it was almost impossible to tear them apart without breaking the skin. The eggs were not held by a ligature, but appeared pasted together by some strong adhesive gum, end to end; most of the eggs were quite distended; the shells of some had fallen in, and they looked crumpled. 
The appearance of the eggs in this dungheap, just as the parent snake or snakes had placed them, was so striking, that I took them home and east them in plaster of Paris, old snake and all. The cast, coloured to nature, is now in my museum.

"There were sixty-four eggs altogether in this one bunch. I do not know from experience how many exgs the common snake lays, but I should say from twenty to thirty. It is, therefore, probable that more than one snake had chosen the spot ou this dunghill to deposit their eggs, just as one salmon will deposit her eggs in a favourable place withont consideration for the other mother salmon that precedes or follows her.

"The temperature where the eggs were deposited [in the dungheap] was about $84^{\circ}$ in the sun, and the nest was buried about eighteen inches deep on the southern aspect, as though the mother snake knew that that was the best place for the eggs. I then proceeded to dissect some of these eggs. A few of them were blanks, containing nothing, but all the rest were good eggs. When the skin was cut through, a quantity of elear albumen came out, just the same as the white of a hen's egg. Floating in this was a yolk of a mueh yellower colour than that of the hen's egg, and inside this yolk was discoverable the embryo snake. Out of the three embryo baby snakes I examined two of them were quite lively, but gelatinous, and as yet not well enough developed to move more than to give a slight wriggle. The heart, however, could distinctly be seen to beat under the transparent skin for sume seconds. The brain also was very prominent. In the drawing two little snakes are represented as just hatehed out. My readers should search for snakes' eggs in old dunghills in August and September. My friend Mr. Burr preserves snakes in his park; he will not allow them to be killed. Vipers, however, are kept down as much as possible."

The drawing (p. 53) shows the wonderful manner in which the vertebræ of snakes are united, so as to combine strength with freedorn of motion. This wondrous structure has been so ably described by Dr. Roget, in his Bridgewater Treatise on Animal and Vegetable Physiology, which everyone should read, that I quote it as a sample of the Doctor's power of describing evidences of design:-

"It is evident that, in the absence of all external instruments of prehension and of progressive motion, it is necessary that the spine should be rendered extremely flexible, so as to adapt itself to a great variety of movements. This extraordinary flexibility is given, first, by the subdivision of the spinal column into a great number of small pieces; secondly, by the great frecdom of 
their articulations; and thirdly, by the peculiar mobility and connection of the ribs.

"Numerous as are the vertebre of the eel, the spine of which consists of above a limndred, that of a serpent is in general formed of a still greater number. In the rattle-snake (Crotalus horridus), there are about two hundred; and above three hundred have been counted in the spine of the Coluber natrix. These vertebræ are all united by ball-and-socket joints, as in the adult batrachia; the posterior rounded eminence of each vertebra being received into the anterior surface of the next. While provision has thus been made for extent of motion, extraordinary care has at the same time been bestowed upon the security of the joints. Thus we find them effectually protected from dislocation by the locking in above and below of the artienlar processes, and by the close investinent of the capsular ligaments. The direction of the surfaces of these processes, and the shape and length

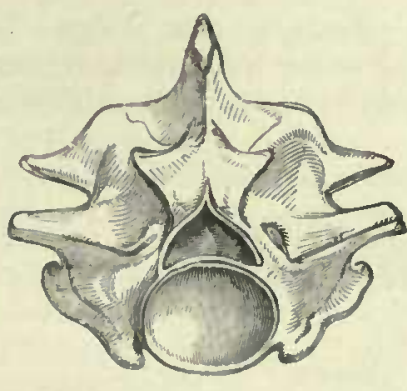

BOCKET.

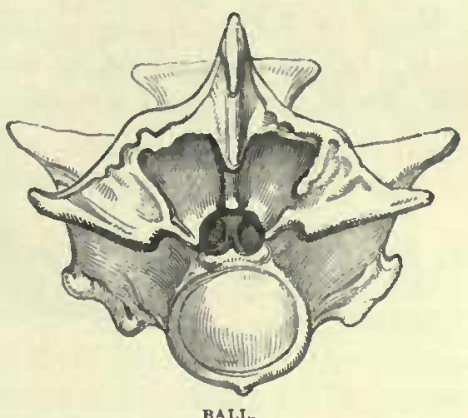

BALI.

VERTEBRA: OF SNAKE.

of the spinous processes, are such as to allow of free lateral flexion, but to limit the vertical and longitudinal motions; and whatever degree of freedom of motion may exist between the adjoining vertebra, that motion being nultiplied along the column, the flexibility of the whole beeomes very great, and admits of its assuming every degree and variety of eurvature. The presence of a sternum, restraining the motions of the ribs, would have impeded all these movements, and would have also been an insurmountable bar to the dilatation of the stomach, which is rendered necessary by the habit of the serpent of gorging its prey entire."

In the Museum of the Royal College of Surgeons, Lineoln's Inm Fields, is a very fine skeleton of the tiger boa, in whicl the above ball-and-socket apparatus ean be examined. It measures eleven feet two inehes, and has no less than two hundred and 
ninety-one vertebræ. Professor Owen writes:-"The vertebre are 'Procælian'-that is, they are articulated together by balland-socket joints, the socket being on the fore part of the centrum, where it forms a deep cup, with its rim sharply definer, the cavity looking not directly forwards, but a little lownwards from the greater prominence of the upper border." In my museum I have the tanned skin of a boa-constrictor, fifteen feet long; it would have been interesting to have known how many vertebre this snake worked. The reader can easily examine the structure of snakes' vertebra for limself; take a snake, the bigger the better (one that has been in spirits will do quite well); cut off his head; run a wire down the spinal column as far as it will go; tie the two ends of the wire together, and boil the snake till the flesh can be easily removed with a knife and brush; the vertebra will then be found to be strung like the beads of a lady's necklace.

Nest of Stickleback, p. 58.-Birds, as we know, build nests, but at first sight it would seem extraordinary that a fish should also build a nest, yet it is so. The sticklebacks

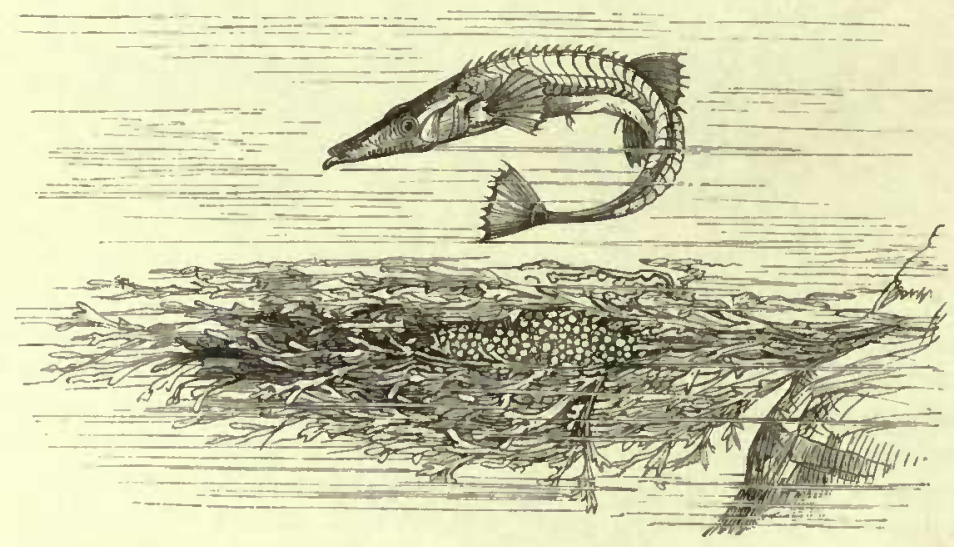

MEST OF BEA STICKLEBACK.

ure the nest-builders. There are three well-marked species of sticklebacks in England; two inhabit fresl water, namely, Gasterosteus aculeatus, which has three spines, and the $G$. pungitius, which has ten spines; the third kind, G. spinachia, lives in the sea, and has fifteen spines. The fresh-water stickleback's nest can be found in the month of May; iny readers should look out for them. In October, 1866, I received 
from Mr. Robert Embleton, of Chathill, Northumberland, a most valuable specimen of the nest of the marine stickleback, which has been drawn by Mr. Delamotte. The late Mr. Jonathan Couch thus describes a stickleback's nest which came under his own observation:- "The situation selected by the fish was the loose end of a rope, from which the strands hung at about a yarel from the surface, over a depth of four or five fathoms, and to which the inaterial could only have been brought, of course, in the mouth of the fish from the distance of about thirty feet. They were formed of the usual aggregation of the finer surts of green and red ore-weed; but they were so matted together in the hollow formed by the untwisted strands of the rope, that the mass constituted an oblong ball of nearly the size of the fist, in which had been deposited the scattered assemblages of spawn, and which was bound into shape with the thread of animal substance, which was passed through and through in various directions, while the repe itself formed an outside covering to the whole." The threads formed by the sticklehack resemble very much an indiarubber band, only they are of a white colour. No human being knows how these threads are formed by this interesting nest-building fish.

Butcher-BIRD, p. 63.-The butcher-bird, or shrike, arrives at the end of April, and remains to the end of Angust. It preys upon beetles, birds, and especially willow-wrens and chiff-chaffs, both young and old, and any young birds from nests. The young of the butcher-bird never comes to its full plumage till it arrives the following season. The young are streaky grey. This bird is very common close round London and all over England; it has a quick jerking call, "lack, lack." $\mathrm{He}$ is a wonderful plucky bird, and will take the "brace birds" off the "flur" sticks" of the bird-catehers. 'They are easy to keep; they feed on brains of birds, always attacking the bird's skull first; they become wonderfully tame, but are only kept for the sake of euriosity. The grent grey shrike comes in winter from Norway and Sweden; it arrives in Oetober and returns in the spring. It is rare; Mr. Davy never had above two in one season. When "hard pushed" the shrike will take almost any bird. It is a wonderful punisher, and has grent power in its beak. The bird generally fixes its dinner on a thorn to hold it while he picks at it. When in a cage he fixes his prey between the bars.

"The red-backed shrike (L. collurio) is a somewhat local bird, and visits us in summer"; it is more common in the east than

\footnotetext{
See next page.
} 
in the western parts of England, but I have found it breeding abundantly in some parts of the west; as, for instance, in Devonshire. One nest in my collection is composed externally of a mixture of grass and roots. The body of the nest is of wool, moss, and grass in layers, forming a substance which, although not very compact, yet has an air of comfort about it.

"Another nest is composed externally of coarse grass, with a small amount of moss, and is compactly bound together. It is cup-shaped, and is lined with horse-bairs and a few roots almost as fine. A small piece of hemp cord garnishes the rim of the nest, which is altogether as strong and easily lifted as one of the hedge-sparrow.

"The eggs are mostly a cream-colonred ground, with spots of ash and pale yellow ochre. Some are of a pale blue, and others are of a salmon-coloured ground. They are variously spotted, from dull ash-coloured green to bright red, which last is generally mixed with pure ash and pale ochre. They have very generally a zone of spots towards the larger end, and are very seldom thickly spotted all over, so as in the least degree to obscure the ground colour, except where the zone of spots is. The number of eggs varies from five to seven."-G. NAPIER.

Mr. Gould gives four Shrikes. Genus Ianius: 1. The great grey shrike, $L$. excubitor; 2 . Lanius minor, rose breasted shrike. Genus Enneoctonus; 3. Butcher-bird, E. collurio; 4. Woodchat shrike, E. rufus.

In order that the reader may understand the menning of the terms "flur stick" and "brace birds," I now give an extract from an article I published in Land and Water, No.501, Aug. 28, 1875, describing a day's bird-catcling at Mr. Burr's park, at Aldermaston, near lieading, witlı Mr. Davy, the bird-catcher. The process of laying the mets is as follows:-Two nets, twelve yards long (and, when open, covering the ground twenty feet wide), are neatly laid down on the ground. It is impossible, without a diagram, to describe the ruugl yet very excellent machinery by which a pull on the rope held by the bird-catcher ${ }^{2}$ will make these harmless-looking nets instantly spring into the air and eatch the birds, either on the wing or on the ground. The nets act so quickly that the eye can scarcely follow their spring. Anything on the wing crossing them four feet high will be shut in instantly. It is better to catch the bird before he

When catching small birds, the bird-catcher stands eighteen yards from the nets ; when catching blackbirds, thrusbes, or starlings, position is taken up at twenty-five yards. 
las time to settle; if he touches the net with his feet he is off' instantly.

The next process in bird-catching is to put out the "brace bird." A brace bird is taken from a cage; this bird always wears his brace with a swivel attached, whether at work or not. The brace consists of a piece of string made into a kind of double halter. It is put over the bird's head, and the wings and legs are passed through ; in fact when I saw Mr. Davy brace a bird I was strongly reminded of a nurse dressing a baby. When the brace is on the bird, the feathers fall over it and it cannot be seen. The brace bird is then put on his "flur stick," this is a straiglit stick, which ly means of a hinge on its lower end is made to rise and fall at the will of the lird-catcher by means of a string. Then when any bird is seen coning the flur stiek is gently pulled up, the brace bird, all the while standing on the stick, is inade to hover with his wings and slow himself; this, of eourse, is to attract the wild birds to the place. The bird-cateher then arranges his eall birds. These birds when put out begin to sing, especially if they hear another bird of the same lind in the distance. The wild ones being attracted by the lecoys are shown by the hrace birds the place where they are wanted to go. No bait is used for the birds, they simply come to the decoy and imagine from the call that they-the decoysare feeding there.

The brace bird that Mr. Davy puts on the flur stick has been at work for three years almost daily. He has been the means of catching thonsands of other birds, especially sparrows, ordinarily called "Jims." Mr. Davy says the call birds get very artful ; sometimes they will give a note of warning to the wild birds; thus a linnet will sometimes set to "hipping," that is, repeating the words, "hip, hip," several times. This note of the call bird causes the linnets eoming in a flight instantly to dash away in all directions. The goldfinch will "oftentimes set to " giclding," that is, saying, "gid," "gid," " gid," several times in succession. This has the same effect as the "hipping" of the linnet. The birds are off in a moment.

JACKDAws, p. 66.-Jackdaws are very 'cute, eunning birds; they are fond of old castles and dilapidated ruins. At Whistley, near Weybridge, the people go in May, when the birds are about a fortnight old, to the ruins of a very old castle. Men carry long laclders, and with blunt iron hooks take out the young jacliduws, and if there are no buyer's they throw them to the ground. Mr. Davy has taken hampers down to Whistley and bronght up all the birds eaught, as inariy as ten dozen of young jackdaws. They cost on the spot $2 s$. per dozen. The reason vol. II. 
why they are taken is to stop the increase of jackdaws in the neighbourhood. If the young jackdaws are taken when about a fortnight old, the old ones will not "go to nest" again that season. If the eggs only were taken, the birds would lay again inmediately. Mr. Jackdaw is "birdivorous;" when he has got his young he looks out where there are young sparrows, then "in he pops, and ont he pops" with a young sparrow, and so he goes on backwards and forwards till he has taken the lot; he then pulls them to pieces afterwards and feeds his young on them in turn.

A curious and very ancient custom at Oxford is connected with jackdaws' eggs. A Latin hymn is sung on the top of Magrdalen Tower, Oxford, at daybreak, on the 1st of May every year. Close to Magdalen Bridge stands the magnificent tower of Magdalen College. The foundation of this structure was laid in 14.92 by l'resident Mayhew. The tower is 150 feet ligh, and contains a very fine peal of ten bells. On May 1st, at daybreak, the choristers assemble at the top of the tower, and sing a Latin hymn as the sun rises. The first verse of the liymn is as follows:-

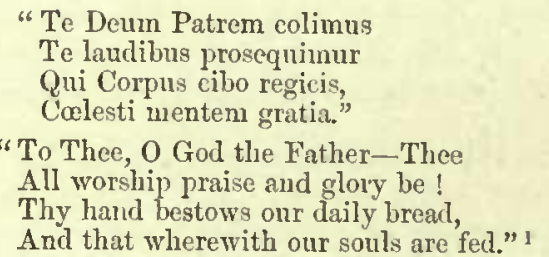

The origin of this custom, it is written, is as follows:- "Previously to the Reformation, a mass was performed every May-day morning at an early hour on the top of this Tower for the repose of the soul of Henry VII., who had honoured the College with a visit in 1488. Certain pieces of choir music are still performed, in the same place and on the same day, at five o'clock in the morning, for which harmonious service the rectory of Slymbridge, in Gloucestershire, pays the yearly sum of $10 l . "$

I have heard another version of this story from my friend Dr. Newman, a Fellow of Magdalen College. He informs me the story goes that, long ago, certain estates were given to the College on condition that a mass was said on belialf of the benefactor on the 1st of May, and that if this mass were omitted the estates were to lapse. After the Reformation they could not say the mass in the chapel, so they went to the top

1 The whole of this hymn can be fonnd in the "Historical Handbook of Oxford." T. Shrimpton and Son, Broad Street, Oxford. Price 2s. 
NATURAL HISTORY OF SELBORNE.

of the tower and sang it at daybreak. When I was a little boy, my father always took me to hear this hymn sung, and we generally stood on Magdalen Bridge. And now comes another very curious custom. After the hymn has been sung, the choristers throw clown eggs, supposed to be those of jackdaws and starlings, collected from the tower, upon the crowd. The people then begin to blow tin horns with long and lond blasts. It is said by some that the origin of this custom was to drown the sound of the mass being sung at the top of the tower. Dr. Newman, however, says that he believes this is the only remnant in England of a Roman ceremony, the 1st of May being the day in which a festival was held in honour of a Roman goddess, or possibly the Floralia, or floral games, which amongst the Romans began on the 28th of April. The celebration of May-day by the chimney-sweeps, and others, may possibly have had its origin from the same old Roman custom.

How Stonentexge was BUILT, p. 66.-Many theories have been advanced as to the mechanical power which was adopted by Druids to handle the enormous stones which built Stonehenge. Captain Dunbar of the Scots Greys tells me that in his opinion they managed it by taking advantage of a heavy fall of snow and severe frost. The snow was packed up between the uprights, filling up the space to a level with the top of them; a plane with a slight incline was then formed with more snow, and water thrown over to form it into a solid mass; the third stone was then levered or rolled up the incline to its position, and when the snow melted the stone would be left in its position. It is quite certain that earth was sometimes used instead of snow for this purpose, to form cromlechs and other megalithic structures; lieat and cold water were probably used to split the stones to the required dimensious.

Near Crickhowell, a few yards from the Usk, there stands in a gentleman's park a solitary monolith: probably the remains of au old Druid temple. My friend Mr. Berrington tells me the local tradition is that, on the eve of St. John, the stone goes down to the Usk and dips itself three times in the water. This is probably the last remnant of some ancient Druidical rite that took place on Midsummer-day symbolical of purification.

TuMing Birds, \&C., p. 68.-Mr. Davy agrees with White. In all his loug experience, he never knew of a bird which could not be tamed. It is very remarkable, that, as a rule, all birds seem to be very timid at the sight of gloves. If you feed a tame thrush with gloves on he will "chuck, chuck, chuck," and dash about the 
cage. This shows fear; the blackbird will do the same thing. Every bird, old or young, can be tamed by kind treatment and knick-knacks in the shape of tempting food. A knick-knack for a soft-feeding bird would be maggots cleaned in sand, and mealworms, and any kind of small beetle; knick-knacks for carnivorous birds would be live mice, small birds, dc.

Claws of Heron, p. 69.--The feet of birds afford a field for very great study. Along the sides of the toes of the capercaillie rum a series of hard, strong bristles, not at all unlike the teeth of an ordinary comb. I believe the use of these is to act as a snow-shoe to help to support the bird wheu walking on the snow. The reader should observe for himself the curious serration on one side of

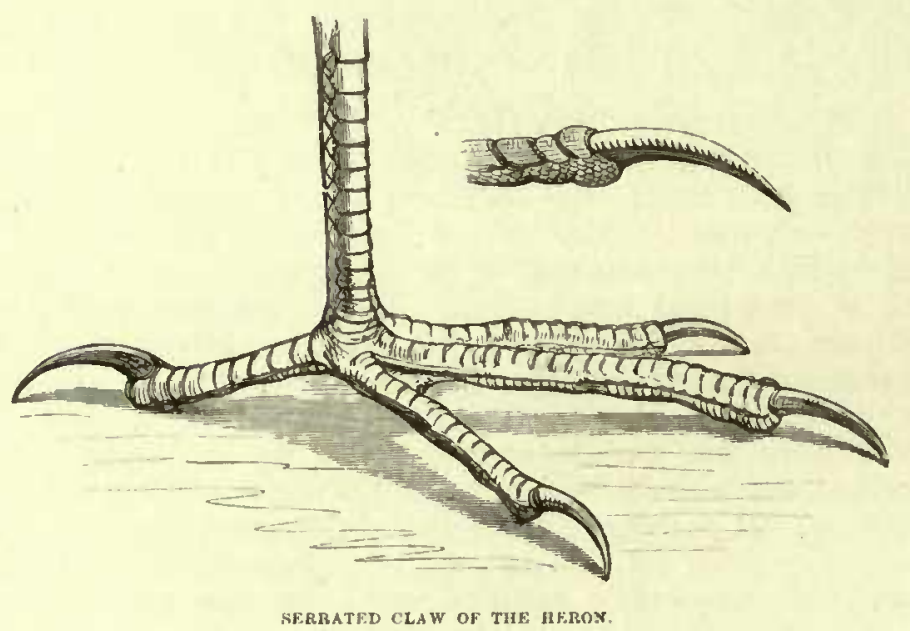

the middle toe of the common heron. The same structure is also found in the bittern and cormorant. The use of it is certainly not for prehension, as was formerly supposed, but rather; as its structure indicates, for a comb. Among the feathers of the heron and bittern can always be found a consideinble quantity of powder. The bird probably uses this comb to keep the powder and feathers in proper order.

FERN-OwL, p. 70.-The Fern-Owl, or Goat-sucker, arrives liere very late in May, the month of cockchafers; the chafers come out with the leaves. The female makes no nest, but lays two egrgs on the bare ground. The churring noise is its song; the male birl does it mostly; the male will "churr" when the 
female is sitting; she ean shift her young when danger is near, she probably rolls them away with her wings. Goat-suekers like to have their nest in the hollow made by a horse's or cow's hoof. They devour large quantities of beetles.

It does not seem likely that this bird should use its foot to eatch beetles; the nouth is evidently adapted to take any sized beetle. If one of them be shot the beetles may be found alive in the pouch, especially when they are feeding their young. These birds make very fair progress on the boughs of the trees; they shuffle, not walk, along the branches. This is one of the very few birds Mr. Davy has not succeeded in keeping long. Mr. Searle informs me that the cockehafers are very small in Berkshire, but in Hampshire they are large. Mr. Davy says that in the ueighbourhood of London you get cockehafers both large and sinall about Hampstead, and especially Lord Mansfield's woorl there.

Colonel Leathes kindly sent me in the summer of 1875 two young fern-owls, taken from the nest in his woods near Yarnouth. I fed then on seraped beef and hard-boiled eggs, and they lived some weeks; they were very tame. The bristles round the sides of the mouth to assist in catehing insects are very remarkable.

INDIAN GRAss, p. 73.-It is quite evident that silkworm gut, now so eommon, was not much known to anglers in the time of White. At the present time it forms the most important item, next to the hooks, in an angler's tackle. I do not think that Izaak Walton, who died in 1683, nsed much gut.

The gut is secreted from a fluid, contained in two long vessels lying at the side of the stomach of the sillkworm; these terminate in a single tube in the centre of the lower lip of the caterpillar, who spins it as he wishes. It is probable that each thread of silk is double, half being secreted from one of the vessels above described, and the other half from its neighbour.

All the treatises upon silk and silkworms, as well as those relating to animal produets, to which I have access are singularly silent mpon the subjeet of silkworm gnt, for the simple reason, I suppose, that the authors knew nothing about the history of the sukject. In my youthful days I used to make the silkworm gut inyself. A silkworm must be watched until he is just beginning to spin. He must then be placel in ordinary vinegar and allowed to soak some forty-eight hours or longer. The operator must then take hold of its 
head and tail and pull them apart. He will find a string stretches out between the head and tail; this is the consolidated silk or the silkworm gut. Place two pins in a board and wind the two extremities on the pins, and leave the gut to dry. The tangled and twisted ends on the gut-hanks one buys are the ends which have been wound round these pins. The gut of commerce is made principally in China, and, I believe, also in Spain.

ARRIVAL of BIRDS, p. 80.--In order to give a comparative table of the arrival of birds at Selborne and in the neighbourhood of London, I give the following list. The London list is given on the authority of Mr. Davy, the bird-catcher:-

$$
\begin{aligned}
& \text { USTALIYY APPEAR ABODT } \\
& \text { SELBORNE. } \\
& \text { LONDON }
\end{aligned}
$$

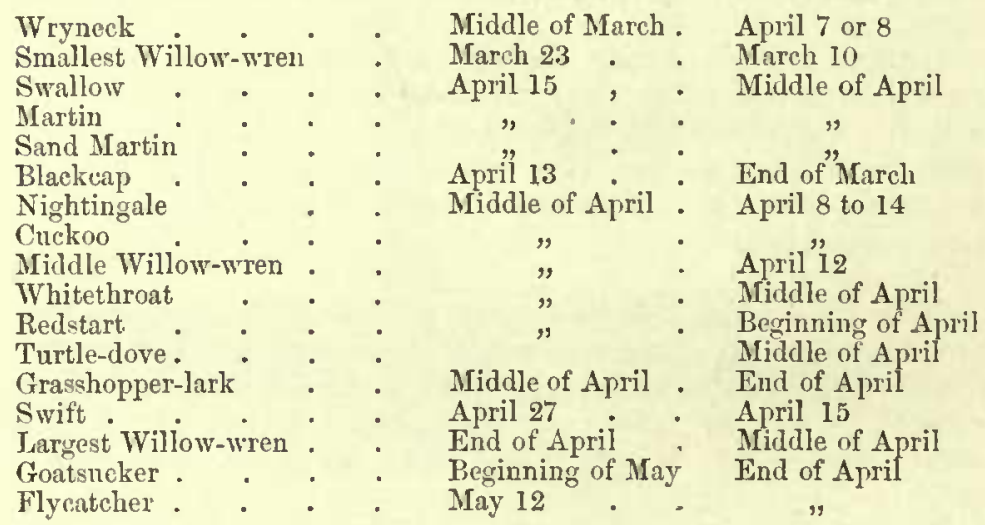

When the flycatcher has arrived we anticipate that all the soft meat tribe are here

When the bird-catchers come home abont the 15 th or 16 th of April, they say that the swifts have arrived.

The following birds stay to the end of August:-the cuckoo, the nightingale, the wryneck. This is a great migratory month. The following birds stay to the end of October:-liouse-swallow, martin, sand-martin. Swallows have been seen in Tottenham Court Road as late as the 5th of November.

Swifts leave about the middle of August; they have been known to stay till the end of September.

"A correspoudent, "J.", thus writes in Land and Water:- " The swift, which visits us generally on the 5 th of May, retires the earliest, seldom later than the 12th of Angust, although a few are ocensionally later, and in one instance a swift was seen on the 26th of August." 
Migrations of Birds from England.-In September and October the greater portion of our summer visitants are nearly all gone or going. Among these we may mention the nightingale, redstart, wryneek, cuckoo (the old cuckoos are gone, but a few young are still left), flycatchers, warblers, turtle-doves, goatsuckers, tree-pipits, slrikes, grasshopper larks. A few of the following still remain:-Blackcap, chiff-chaff, meadow pipit, White's wagtail, Ray's wagtail, willow-wren, wheatear, large and lesser whitethroat, \&o. These are soft billed or soft ment birds, which leave England in the antumn. About the same time that these birds leave us, others arrive, such as goldfinches, woodlarks, skylarks, linnets, redpoles, twites, siskins, and snowbuntings. About the second week in September, the flights of these commence and last for three weeks or a month. The antumn arrivals are seed-eating birds. The London bird-catchers at this "flight time," go down to the south coast for their harvest, and take large quantities of the arriving birds, many thousands are sent up weekly to London for cage birds, and to be kept for their song. At the end of March the birds wlich left us in September and Oetober begin to return to this country.

Birds seen at Kinberjey, Norfolk.-The Rev. F. O. Morris thus writes in Land and Water:- "I received the following list of birds seen at or near Kimberley (Norfolk), from the Earl of Kimberley, about a fortnight ago, and I lave his permission to send it to you for publication :here.

1. The Golden Eagle twice seen

2. Osprey several times; remains here sometimes fishing for several days. rare.

3. Buzzard occasionally, now

4. Kite I have seen once.

5. Peregrine Falcon I have scen once.

6. IIobby, latterly none seen.

7. Kestrel, common.

8. Sparrowhawk, common.

9. Long-eared Owl, not uncommon.

10. Tawny Owl, formerly common, now rare.

11. White Owl numerous, since I have prevented the gamekcepers from destroying them.

12. Grey Shrike, seen occasionally, but rare.
13. Red-backed Slırike, seen occasionally, but rare; I saw a pair this September.

14. Great Tit, common.

15. Cole Tit, common.

16. Blue 'lit, common.

17. Marsh Tit, common.

18. Long-tailed Tit, common.

19. Spotted Flycatcher, common.

20. Kingfisher frequent; particuJarly abundant this year, owing, no doubt, to recent mild winters. In long severo frosts we have found many dead.

21. Ravens used to breed (one pair) here every year, now scldoin seen ; I suw a pair two years ago.

22. Crow, not many.

23. Hooded Crow, numerous in winter.

24. Rook, very numerous.

25. Jackdaw, very numierous. 
26. Jay, common.

27. Nuthatch, common.

28. Wryneck, frequent in spring.

29. Creeper, comnion.

30. Green Woodpecker, frequent ; breed in the park here every year.

31. Great Spotted Woodpecker frequent; breed in the park here every year.

32. Lesser Spotted Woodpecker,

rare; seen this and last year.

33. Cuckoo, common.

34. Nightjar, occasional.

35. Swift,
36. Swallow,
37. Martin,
38. Sand-martin, $\left\{\begin{array}{l}\text { Abundant usu- } \\ \text { ally, but tlis } \\ \text { year very few, } \\ \text { owing no doubt } \\ \text { to the extraor- } \\ \text { dinary scarcity } \\ \text { of insects. }\end{array}\right.$

39. Pied Wagtail, frequent (fow this year).

40. Grey Wagtail, frequent (few this year).

41. Yellow Wagtail, not common.

42. Greenfinch, a bundant.

43. Hawfinch, occasional ; a pair nested here this spring.

44. Bramble-finch, a good many in the winter of 1873 .

45. Goldfinch, not many.

46. Siskin, occasional flocks.

47. Linnet, numerous.

48. Redpole, occasional; but I have not observed whether common.

49. Bullfinch, abundant.

50. Dipper has been seen-the egos found two years ago.

51. Starling, very numerous.

52. Missel Thrush, very numerous.

53. Fieldfare, very numerous.

54. Redwing, very numerous.

55. Thrush, very numerous.

56. Blackbird, very numerous.

57. Redstart, frequent.

58. Nightingale, abundant ; many breed here.

59. Dunnock, very common.

60. Blackcap I have seen, but an not sure whether it is frequent.

61. Wren, abundant.

62. Goldcrest, common

63. Woodlark, occasional.

64. Skylark, abundant.

65. Bunting, common.
66. Snow Bunting, seen occasionally.

67. Yellowhammer, common.

68. Chaffinch, abundant.

69. Redbreast, abundant.

70. Woodpigeon, abuudant.

71. Stockdove, common.

72. Turtledove, common; many breed here.

73. Pheasant, common.

74. Partridge, common.

75. Red-legged Partridge, cominon.

76. Quail, rare ; a nest lıere three or four years ago.

77. Golden Plover, occasional flocks.

78. Peewit, flockg in winter, a îew breed.

79. Heron, a sinall heronry here, nine or ten nests.

80. Common Sandpiper, occasional.

81. Green Sandpiper, occasionally seen.

82. Woodcock, a few; a nest hatched off in 1872 .

83. Great Snipe, two years ago I saw a pair. here.

84. Common Snipe, a few breed

85. Jack Snipe, the numbers of this and the common snipe much diminished by draining.

86. Landrail, occasional, fewer than formerly.

87. Spotted Crake, rare.

88. Water-rail, wuch less frequent than formerly.

89. Coot, occasional.

90. Moorhen, abundant.

91. Grey Iag Goose, occasionally, but much rarer than formerly.

92. Pink-footed Goose, have seen one.

93. Egyptian Goose, ouce or twice.

94. Canada Goose, kept tame, breed freely.

95. Hoopoe, occasionally in hard winters; two years ago a small thock (five) stayed late into spring. My keeper said they got quite tame, and he thought at onc tinie they would stay and breed. 
96. Sheldrake, rare.

97. Shoveller, rare.

98. Gadwall, rare.

99. Pintail, occasionally in winter.

100. Wild Duck, commion.

101. Teal, not uncommun.

102. Widgeon, not uncommon.

103. Pochard, common, some winters.

104. Scaup, occasional in winter.

105. Tufted Duck, not uncommon

in winter.

106. Golden Eye, not nncommon.

107. Smew, bave twice seen small

flocks in winter.

108. Goosinder, occasional in hard weather, but never an old male bird.

109. Great-crested Grebe, a par lreed every year on a mere belonging to me.
110. Dusky Grebe, a pair slint here a few years ago.

111. Dabchick, not uncommon.

112. Cormorant, four or five birds togrether twice seen here.

113. Lesser Tern, seen in 1873.

114. Common Tern, frequently seen here formerly, now hardly ever.

115. Black Tern, I once saw a small flock.

116. Black-headed Gull, frequently seen, as they breed at a place abont six miles distant. [N.B.-This bird's legs, feet, and beak are bright red. I have often seen then when just dead. They lose their colour soon after death.]

117. Common Gull, occasional.

118. Kittiwake, occasional.

"It is very singular that the number of birds observed on I.ord Kimberley's estate is all but exactly the same, namely 119, as were observed by Mr. Waterton at one time or other at Walton Hall. It is very gratifying also to see it stated by his Lordship that the white owls have become numerous since he gave orders for their protection, showing what miglit be done by other landed proprictors if so minded. In one of his notes he says, "I heartily sympathise with you in your desire that the young should be trained in habits of kindness to all dumb creatures. Nothing is more hateful than the eagerness which possesses so many people to kill every wild creature that comes in their way." "-F. O. Morris.

THE following is the list of Birds which had been captured or observed in the Zoological Society's Gardens, Regent's Park, by Mr. Fdward Bartlett, son of Mr. Bartleit, the Superintendent (Transactions of Zoological Society, 1863, p. 159):-

Kestrel.

Barn owl

* Spotted Flycatcher.

† Missel Thrush.

+ Fieldfare.

* +Soug Thrush.

tRedwing.

* Blackbird.

Rinu-Ousel.

*Hedge Accentor.

*+Redbreast.

Wheatear. VOL. II.
*Reed Warbler.

Sedge Warbler.

Nightingale.

* Blackcap.

Garden Warbler.

†Coumon Whitethroat.

+Lesser Whitethroat.

Wood Warbler.

Willow Warbler.

Chiff Chaff.

Golden-Crested Regulus.

+Great Tit. 
†Blue Tit.

Cole Tit.

Marsh Tit.

+Long Tailed Tit.

Pied Wagtail.

Grey Wagtail.

Ray's Wagtail.

Tree Pipit.

Meadow Pipit.

†Skylark.

Cominon Bunting.

+Chaffinch.

tHouse Sparrow.

Greenfinch.

Hawfinch.

Goldfinch.

Comuron Linnet.

Those marked * have been observed to breed in the Society's Gardens; those marked + have been observed by myself or Mr. Searle, my secretary, in my little garden, 37, Albanv Street, or in Regent's Park adjoining. The cuckoo was also seen this year, 1875 , in the long walk by Mr. Searle.

Brisds' Ciops, p. 84.- - In his lectures on Geology at Oxford, my father used to tell us that the sellers of antiquities at Rome had a curious and elever way of giving the appearance of antiquity to moderu gems. Having cut the device on the stones, they thrust them down the throat of a turkey into his gizzard; after the proper time had passed they killed the bird; the stones in the crop were then found to have assumed the corrugated appealance of antiquity from the grinding action of the hard ccats of the turkey's gizzard. In my collection I have some fine specinens of stones found in guano polished by the action of birds' stomachs.

Sediebird, p. 86.-Mr. Davy thinks it is very likely that the bird here mentioned by White was the reed-warbler, or reed-wren. If disturbed by any means during the night it immediately commences its song, which resembles a mixtmie of other songs of birds, a regular gibberish altogether. In some parts of the country they call it the "thousand songster." These birds partially resemble the reed-sparrow; they are migratory. The young birds do not come to their full plumage till the following spring.

SNake-Taming IN Loxdon, p. 86.-A friend of mine, Mr. Mann, Professor of Music, has a most remarkable power of taming snakes. I now describe my first introduction to his snakery. 
He placed in the middle of the room a large box, which was carefully locked. He told me the box was always locked, unless he or his wife took out the snakes to feed or examine thein. The first he produced from the box was a very fine common British snake (Coluber natrix). His snakes have all got names, and this one's name was Julia. Julia not long ago laid thirtysix eggs, which were hatched out successfully. The next was also a common British snake. The ring round the neck was very bright in this snake. She rejoices in the name of Sylvia. Sylvia is very good at frogs ; lately she atc nine frogs, seven large frogs and two small, at one meal, one after the other. Mr. Mann has also two other common snakes, whose names are Proteus and Beatrice, or She of the Golden Hair. This modern snakecharmer then dived his hand into the box, and brought out an exceedingly lively brown-coloured snake. The head is remarkably pretty and lizard-like, and it has the power of moving the head very quiekly from side to side; the eye is also remarkably brilliant. This snake was bought from Jamrach; it is called a Lacertine, and comes from the coast of Mogador, Northern Africa ; it is perfectly harmless. Mr. Mann has had the lacertine about twenty months. It is a pretty, elegant creature. It feeds on white mice.

Mr. Mann then slowed me the gem of his collection. It is a remarkably handsome Brazilian boa, measuring between five and six feet long, and weighing from twelve to fourteen pounds. The name of this snake is "Cleo," short for Cleopatra. Continual bandling and petting has cansed this snake to become most remarkably tame, and I think there can be no doubt that she knows individuals. When placed on the table, "Cleo" would not come to me at all, but glided away to lier master, who was sitting at the opposite side of the table, and stretching her length from the table to the chair, gradually pulled her long body on to him. She then glided up his right side, and folding her coils round his neck, placed her head close to her master's face, and there she lay for some minutes quivering her black forked tongue with evident pleasure. Mr. Mann's two little children, aged five and six respectively, then came into the room. They inmediately ran to the suake and began playing with it, kissing it, and pulling it, calling it "Cleo; dear Cleo." "Cleo" was then made to glide on the floor; the children ran after her and picked her up, and the little girl twisted her up round her neck like a boa. (I wonder if this was the origin of the word boa?) "Cleo" evidently enjoyed the fun as much as the children. It was very curions to see these two little children encireled in "Cleo's" jonderous folds, reminding me much of 
the celebrated statue of the Laocoön, and, if I recollect rioht, the marble children in the statue are represented as about the same age and size as Mr. Mann's two ehildren. "Cleo" is a particular favourite of Mrs. Mann's, and I saw a very nice photograply of her, with "Cleo" coiled round her neck. I subsequently saw Mrs. Mann in this attitude, with her pet snake. "Cleo," has shed her skin several times, and it is enrious to remark that she has shed her skin ten times in two years. Mr. Mamm has the last skin shed. It is quite perfect, and as thin as tissue paper, and I sloould think would make good pattern for fancy lace work.

"Cleo" feeds principally on pigeons. If a pigeon is put into lier cage, and she is not hungry, sle seems to make friends with the pigeon, and will never attempt to eat it. Should, however, a fresh pigeon be put into lier cage, she will devour it instantly. She feeds once a fortnight, and two pigeons will about last her for this time. Mr. Mann has observed that when let loose "Cleo" always tries to climb upwards, whereas the Lacertine always seeks the groumd. "Cleo" most certainly knows her" master and mistress. Once, when they went ont of town, "Cleo" was sent away. She pined and wonld not feed during their absenee. When Mr. and Mrs. Mann returned, after six weeks' absence, "Cleo," on hearing her mistress's voice, instantly ruslied out of her box, curled herself round her, and kissed lier fince. She evidently recognised her kind friends and protectors.

Mr. Mann has also a large Indian python, but this snake is not very well, and has private apartments to itself in a leather earpet-bag. The snakes will feed out of Mr. Mann's liand. The common snakes eat frogs, and frogs only; the Lacertine eats white mice; the python delights in guinea-pigs. Altogether I was exceedingly pleased with Mr. Mamn's collection of snakes. By his very suceessful snake-taming he lias opened up quite a new chapter in natural history, and has shown what persevering lindness will do in taming snakes, poor creatures which have hitherto been thonght to have little or no intelligence.

Song Thrush, p. 90-This bird "forms its nest of dry grass firmly agglomerated with elay, to which rotten wood or cow-dung is often added. The nest differs from that of most birds in being hard and firm inside. A well-made nest of this bird's will hold water, and the boughs on which it is placed often spront. The eggs of the song thrush are of a fine blue, with perhaps a slight tinge of green. They vary greatly in size. They are generally marked with black spots, but I lave four eggs marked witl oclire spots. A zone of spots is rare in this species, as in all the 
British thmshes. Its eggs are found from April to Jume, and are from four to six in number."-G. NAPIER.

The following is from ny description of a day's bird-eatching at Aldermaston Park :- $A$ s it was very hot we sat down in the shade to rest, while Mr. Davy gave us a yarn about his birds. It was unusual for a thrush to be in song so late, viz., 17th August, as at this time these birds are in full moult. August, in fact, is the dullest month in the year for song. Nearly all the birds, being "sore in moult," hide away in damp, shady places. Mr. Davy has put the song of most birds into words. He repeated the words of a thrush's song, and I found by carefully listening that the bird does actually sing the following words :-

Knee deep, knee deep, knee deep ;

Cherry du, cherry du, eherry du, cherry du ;

White hat, white hat;

Pretty Joey, pretty Joey, pretty Joey.

My readers shonld learn these words by heart, and listen to a thrush singing. They will find the thrush pronounces the above words as nearly as possible. Repeat them all, even when no bird is present, rapidly in a bird-like mamner and see the effect.

It is very difficult to "word" a blackbird's song. Mr. Davy can imitate a blackbird's song so well that he eas bring Mr. Blackbird up to him to be caught, but he cannot put his song into words.

Missel Thrusir, p. 90.-The Missel Thrush (Turdus viscivorus) "is generally distributed in the breecling season; it frequently builds in trees too high up to be reached without elimbing. It forms its nest of grass, which it strengthens with clay at the botton! ; but it usually interweaves wool with the grass, which forms the sides. The lining, however, consists entirely of fine grass. I have a nest where no wool is used. It was taken at Abbotsleigh Down, Hunts, a neighbourhood where no sheep graze. Some sticks and grey lichens, however, are nsed in the outside layer of material. The eggs of the missel thrush vary much in form, shape, and colouring. One variety is pear-shaped, of a blue ground with the spots gathered towards the larger end. One variety has a buff ground, with lilac and purple oehre spots. A second has a pale blue gromnd, with lilae and dark ochre spots. A third has the ground colour of the egg of a song thrush, with spots of olive green; a fourth is of a deep flesh colour, with spots of dark ochre; and a fifth has a blue green ground, with spots of ochre gatherer towards the small end. I have one egg which cannot be distinguished from a ring ousel's. My eggrs of 
the missel thrush have been selected from some hundred specimens. It lays from four to five eggs. The missel thrush is the largest of our native thrushes. The origin of the name is 112 certain; they are very common all over England, nevertheless they are migratory, and come with the felts and redwings, feeding on the mountain ash and other berries. They are nevel' kept in captivity ; they sing almost any time of the year, except autumn; they are very good eating."-G. NAPIER.

Missel Thrusi's Nest, p. 90.- "H." (Wexford) thus writes to Land and Water"- "One of my young ones informed me there was a missel thrush's nest made nearly entirely of scraps of newspapers that they had picked up, and a few days afterwards I heard of a blackbird's sinilarly constructed. On looking at the latter, what was my surprise to find nearly all the scraps were portions of your puper, Land and Water. May I ask, Was this natural selection? Where the birds got the paper there were scraps of half a dozen different newspapers, and how were these blackbirds able to pick out those of your own paper from all the others?"

Blackbird's Nest Ornamented with Lace. - Mr. Hugh Hamilton, of Pinmore, Girvan, in Sept. 1875, wrote me as follows:--"In the month of May some laces were laid out on the washing-green folded all together. They were left out all night, but when looked for in the morning were uot to be found. As there was a good deal of wind in the night it was thought they night have been blown over into a neighbour's garden, but the gardens were searched without success. About three weeks after, one of the neighbour's gardeners brought a blackbird's nest with five eggs in it, to the owner of the lace, which he had found in a tree in his garden. It was festooned with the lace as in the plotograph. There were three different kinds of lace $-2 \frac{1}{4}$ yards Lisle, 1 yard Mechlin, and $1 \frac{1}{2}$ yards Valenciennes, besides several pieces of other lace worked in and out throughout the nest, which were destroyed in detaching it. I inclose a photograph which I took myself." Mr. Hamilton has allowed this photograph to be copied for this book. The reader will agree with me that it has been most beautifully drawn and does great credit to the able pencil of Mr. Delamotte of King's College. My answer was as follows:- "I have no doubt the blackbird used the lace in making its nest. An interesting question arises from this as to whether the blackbird had an idea that his nest would be ornamented with the lace. The 
bower-bird certainly uses ornamental snbstances in making his nest ; it is a question if this bird had the same notions."

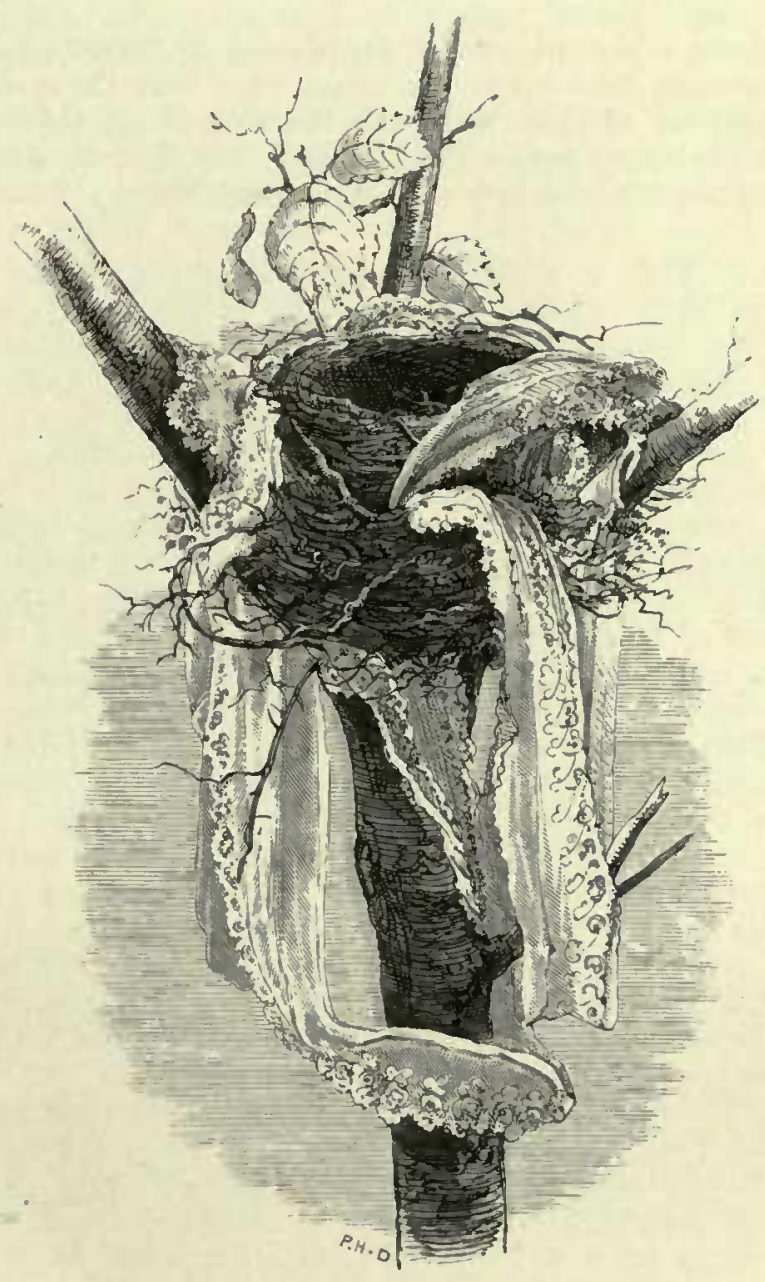

HLACKBIRD'S YEST ORNAYENTED WITU LACE.

The blackbird is a great mimic, or rather a true mockingbird. If taken young he may be taught to whistle one or two - not more-tunes perfectly. Davy had a blackbirl that would whistle, "Pop goes the weasel," and "Hey, jim along, jim along, 
.Tosey, hey, jim along, jim along Joe." "He would sing at any time at command. Mr. Searle, my secretary, says he heard a liackbird in the Mile-end Road, whistle the principal parts of the "Huntsman's Chorus"

If anyone wishes to try the experinent of training a blackbird they must raise one or two young ones from the nest. As a rule two out of three will take the song taught them. The blackbird is a very pugnacious bird, and this is a drawback to his being kept in an aviary with other small birds.

IitThe Water Sirnew (Sorex fodiens), p. 91.-" Little lod" writes in Land and Water:-." It wonld, I am sure, gratify you to see a brood of these elegant little animals disporting themselves in the water. "It frequents ditches and hrooks, in the banks of which it makes extensive burrows. It swims and dives with much address, the sides being spread vit, the belly flattened, and the tail extended as a rudder. When diving, the black glossy coat of the animal appears as if beautifully frosted over with silver, from the innumerable bubbles of air that cover it.' The above quotation is from the 'Museum of Animated Nature.' I have good reason to believe that the water shrew, though seldom seen except by some keensighted naturalist, especially one of angling proclivities, is not particularly scarce. I have frequently noticed it of late years in various parts of Cumberland. During the very droughty summer of 1868 , when a brook which ran through a neighhour's garden was dried up, all but a little pool here and there, I was much amused by watching a couple of them as they stealthily left the overhanging bank and ran to the pool, sipping a few drops in haste, and then scurrying away to their stronghold, as if astounded at their temerity in exposing themselves to the gaze of one who certainly entertained no lostile intentions towards such harmless little crentures."

These little creatures eat insects and fish ; their teeth are very heautiful. I once dissected a water shrew. The stomach and intestines contained some dark fluid pulp-like matter. This I examined under the microscope and found to be composed almost entirely of the horny cases and legs of minute water-insects.

The Shrew Mouse, p. 199.-White here mentions the shrew mouse. These little things are often found dead without any apparent mark of injury; some say that the cats kill them, but will not eat them.

According to Mr. Davy's experience, shrew mice are silly things; they get into dry ditches and cart-ruts, then run "I 
and down, and worry thenselves; they have not sense to get ont of the rut, and so they lie down and perish. Some say that they die because they cannot get water; they are mostly found dead in numbers at the approach of autminn in hot, dry weather; they soon decompose after death.

BlackCap, p. 93.- This bird is also called the "mock nightingale," and the " Norfolk nightingale," and is very easily kept in confinement. These birds do well upon such food as brearl crumbs, bruised henipseed, and a little hard-boiled egg and German paste mixed; they are long lived, and sing freely many months in the year. Numbers are kept in confinement by London fanciers. They are very common in Derbyshire, although there are no nightingales there. Blackcaps do not mind the cold and frostr weather, as they come as early as before the end of March. When they first come they feed on ivy berries. In the autumn they eat quantities of fruit, currants, pears, plunns, \&c. The Baroness Burdett Coutts has some large trees close to her residence at Highgate which are covered with ivy. This ivy produces an abundance of berries; as a rule the blackeaps are noticed feeding on the Baroness's ivy earlier than anywhere. They are very close-feathered, hardy birds; when freshly caught, as a rule, fow or none are lost, in "meating off." The blackeap fattens upon ripe elder berries for the migration.

From Angust up to the middle of September is the time when all the London bird-catchers take large uumbers of "soft meat" $I$ birds, as they are then "clean monlted" and "meat off" much easier.

Mr. Napier writes:- "The egrs of the blackcap are generally a good deal smaller than those of the garden warbler. These varieties very much resemble in colouring those of the blackcap; a most beautiful variety has the ground of a pale pinkish white, clouded all over with rich reddish marks, with a few nearly black spots. A third variety is white, with spots of ash and ochre, principally gathered towards the large end, but without the nearly black spots so general in the eggs of this bird. These black spots are supposed by some zoologists to be the distinguishing nark between the eggs of the garden warbler and the blackcap. The nest of the blackcap is a loose structure, often formed of grass or the stems of bedstraw or umbelliferous plants, and is usually lined with hair. It is a summer visitor to Britain, and has nsually eggs (which are from four to five in number) abont the months of May and June."

1 "Soft meat" birds are the insect-feeders. "Meating off" means inducing the birds to take artificial food in captivity.

VOL. II. 
The Yeliowhamier, p. 93. - This is one of our most common birds, and does not migrate. Mr. Davy never knew of flocks coming to this country. They are not, as a rule, kept as cage-birds, the song not being thouglit anything of. The song of the yellowhammer is very simple-"Widdle, widdle, widdle, cee, cee, cha." In some part of the country the bird is said to sing thus: "A little bit of bread and no c-h-e--e-s-e."

They liave no song during the winter months. "They breed late on tile ground in banks, and have three nests a year, from April to the end of August.

Tituark or Tree Pipit, p. 94.-This bird, a very common one, arrives at the beginning of April, and begins to migrate in the middle of Angust. It is very much sought after for its song and for improving the song of mestling linnets. The linnets thus educated have a mixed song, and are used for "call-birds." Their song reads thus: "Heep, heep, heep, tollyke, eke, pipe, chow, wheet, wheet, fear, lug, orcher, wheet." This is a mixerl song of the native linnet improved by the titlark. The words introduced by the titlark into the linnet's song are "fearing" and "chowing." Titlarks are easily kept, and sing well in captivity. They will sing when perched and also when on the wing.

Cucroo, p. 95.-I have had several young cuckoos sent me from time to time. The cry is very peculiar. On one occasion, Mr. Bartlett chanced to come into my room, where I had a young cuckoo he could not see. I asked him what that cry was; he said "the cry of the young of some soft-billed bird ;" this plaintive cry is a wonderful provision to attract soft-billed birds to feed the helpless cuckoo in its foster-mother's nest. 'The cuckoo almost always picks out the dead branch of a tree from which to call. It may be attracted by calling and imitating its cry. Mr. Edon reports that when he has decoyed the cuckoo in this way, lie finds that, after being deceived and not finding what it expected (say in three visits to the same spot), the bird will not come near again, but will stay at a distance and keep on answering.

Cuckoos are very partial to hedge sparrows' nests. One pair of hedge sparrows could not feed such a glutton as a young cuckoo. Its peculiar cry attracts other soft meat birds to help to feed it.

A young cuckoo when well fledged could be easily mistaken for a nightjar when on the wing in the open.

Cuckoos feed upon caterpillars on high trees. They arrive here in April and depart about the end of August.

1 See also page 43. 


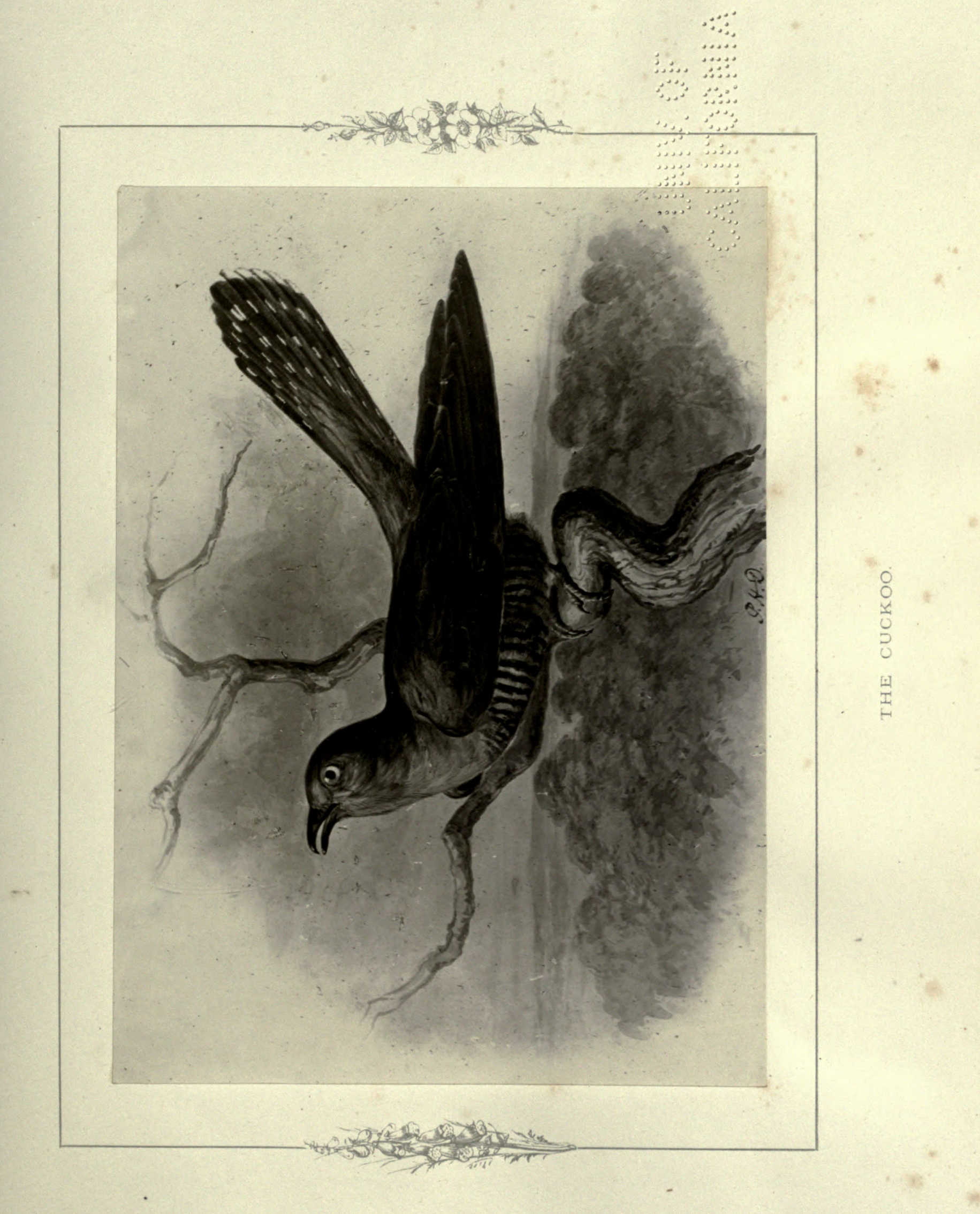


$\because \because$

uㅏ.

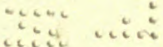

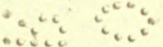

and...

:

:...

- $\therefore$

$\because \ldots .$.

$\because:$ : :...

$\because \because$

$x^{2} e^{2}$ 
The places they choose to lay their eggs are the nests of waytails, titlarks, \&c., and other "soft meat" birds. Mr. Davy has never found the euckoo's egg or young in any other than a "soft neat" bird's nest.

As regards the way in which the young cuckoo turns the young of its foster parents ont of the nest, Mr. Gould writes as follows in his "Introduction to the Birds of Great Britain:"

"A lady of considerable ability as an observer of nature and as an artist has actually seen this act performed, and has illustrated her staternent of the fact by a sketch taken at the time, a tracing of which has been kindly sent to me by the Duke of Argyll. The sketch was accompanied by Mrs. Blackburn's account of the circumstance, which is here given from No. 124 of Nature

"The sketch itself seerns to me to be the only addition I have made to the admirable description given by Dr. Jenner in his letter to John Hunter, printed in the 'Philosophical Transactions' for 1788 (vol. lxxviii., pp. 225, 226.)

"'The nest (which we watched last June, after finding the cuckoo's egg in it) was that of the common meadow-pipit (titlark, mosscheeper), and had two pipit's eggs besides that of the cuckoo. It was below a heather bush, on the declivity of a low abrupt bank ou a Highland hill-side in Moidart.

" "At one visit the pipits were found to be hatched, but not the cuckoo. At the next visit, which was after an interval of fortyeight hours, we found the young cuckoo alone in the nest, and both the young pipits lying down the bank about ten inches from the margin of the nest, but quite lively after being warmerl in the hand. They were replaced in the nest beside the cuckoo, which struggled about till it got its back under one of them, when it climbed backwards directly up the open side of the nest, and hitched the pipit from its back on to the edge. It then stood quite upright on its legs, which were straddled wide apart, with the claws firmly fixed halfway down the inside of the nest, anong the interlacing fibres of which the nest was woven, and, stretching its wings wide apart and backwards, it elbowed the pipit fairly over the margin so far that its struggles took it down the bank instead of back into the nest.

" After this the cuckoo stood a minute or two, feeling back with its wings, as if to make sure that the pipit was fairly overboard, and then subsided into the botton of the nest.

"The cuckoo was perfectly naked, without a vestige of a feather, or even a hint of future feathers; its eyes were not yet opened, and its neck seemed too weak to support the weight of its head. The pipits had well-developed quills on the wings 
and back, and had bright eyes partially open. Yet they seemed quite helpless under the manipulations of the cuckoo, which looked a much less developed creatnre. The cuckoo's legs, however, seemed very muscular, and it appeared to feel about with its wings, which were absolntely featherless, as with hands, the 'spurious wings' (unusually large in proportion) looking like a spread-out thumb. The most singular thing of all was the direct purpose with which the blind little monster made for the open side of the nest, the only part where it could throw its burthen (lown the bank." "

I was informed by a fellow-passenger in the train when going to Selborne, "that cuckoos eat other birds' eggs." My informant said he knew it for a certainty. It is extraordinary that such ignorance can still exist, especially in the neighlbourhood of Selborne.

Mr. King, of Wiggenhall, Watford, tells me that a young lndy counted the call of the cuckoo one fine morning about 4 A.M. ; the first time, the bird cried "cuckoo" eighty times, the second time, he cried no less than one hundred and thirty times witlout intermission.

HedGeHor, p. 97.- In the bristles of the common hedgehng we find a very curious bit of mechanism. The hedgehog has no horny studs, either fastened into the skin, as in the armadillo (see p. 111), nor yet has he a bone-formed dome, covered with horny scales, as in the tortoise (see p. 112). Instead of this his horny covering assnmes the form of spines, or bristles, each set firmly into the skin at one end, and very sharply pointed at the other encl. These bristles the owner can erect in groups, with all the points outwards, presenting a most formidable array of weapons; hut the hedgehog has also power to lay back all these sharppointed spines in one direction, viz., from his head backwards. In this position they form a carpet, which if smoothed the right way with the hand is as soft as velvet. In order to find ont how all this mechanism was carried ont, I have dissected a hedgehog, and was surprised to find how very slight are the muscles which command the spine. They are fine strings of fibres, very similar to the Corugator supereilii, or frowning muscle in our own forehead; in fact, when a hedgehog curls liimself up, he begius work with a tremendous frown as he tucks his head inwards. The muscles that work the spines are attached to prominences which project from the backbone, and especially do they spring from the ribs, which I find to be of innusual strength and abnormal width for so small an animal. 'The vertebre are attached to the ribs in a very peculiar manner, 


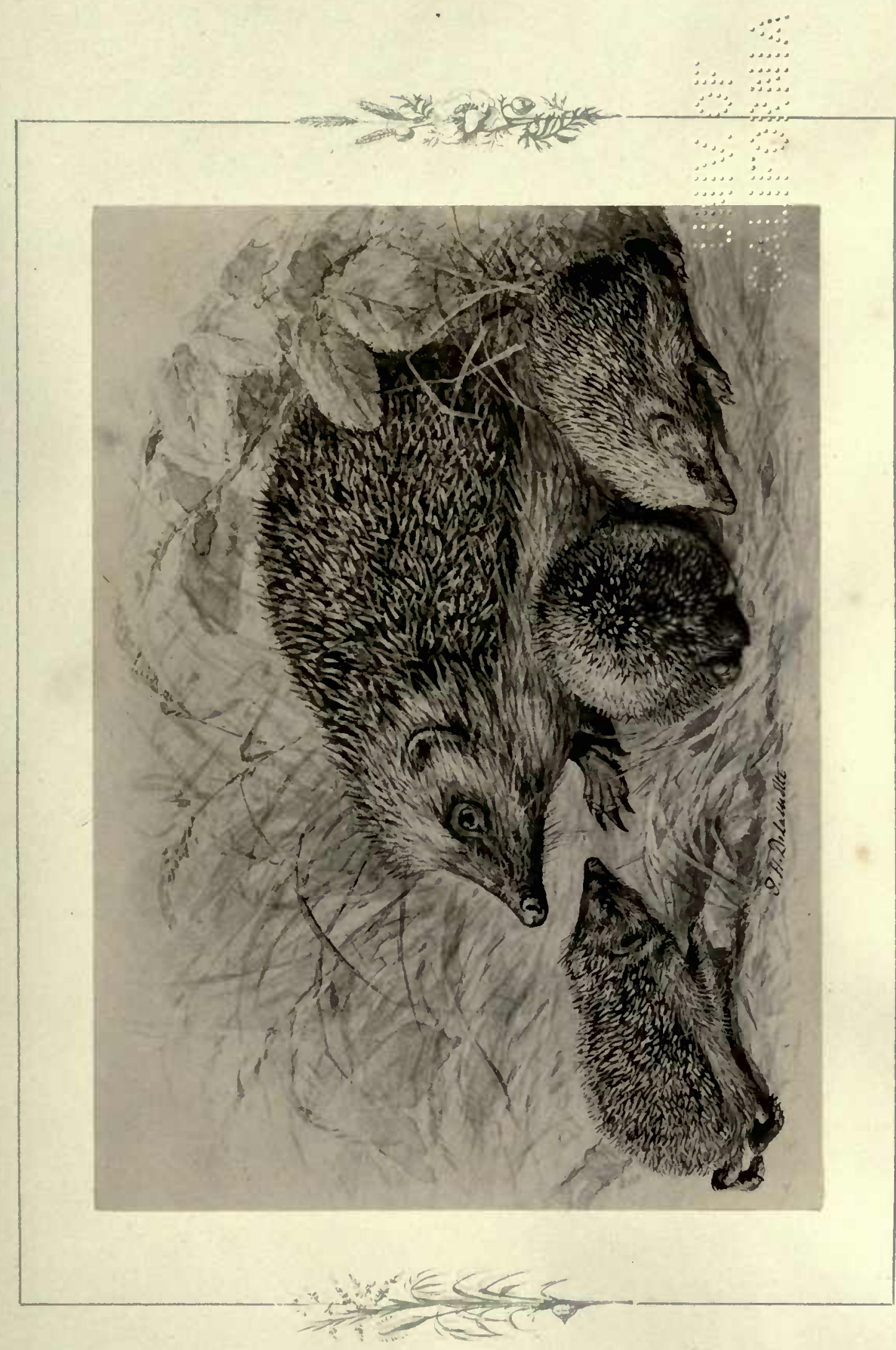




$$
\begin{aligned}
& \because \because \\
& \because \ldots \text {. … } \\
& \text { ais. …… } \\
& \text { ษ". } \\
& \text { ta... .... } \\
& \therefore \text { : } \\
& \text { cute cot }
\end{aligned}
$$

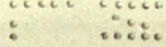

$$
\begin{aligned}
& \because \ldots \text {..... }
\end{aligned}
$$

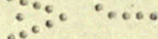

$$
\begin{aligned}
& \therefore \text { : }
\end{aligned}
$$


and each of the backbones fits on to its neighbour by a wonderful joint, which keeps the chain of bones quite stiff when the animal is walking, bnt enables him to coil up into a ball at the slightest provocation. I find that the hedgehog has a clavicle, or collar-bone, evidently for the purpose of using his fore-paws for digging. His digging elaws are also peenliar, and when curved together assume a shape very like that of the anteater, the fellow who pulls down the ants' nests with his tremendous claws.

Being anxious to settle the point, mentioned by White, as to whether the spines of the hedgehog at birth are soft, I obtained a hedgehog from my brother-in-law, the Rev. H. Gordon, Harting Rectory, Petersfield. To my great delight I one morning found, among the straw in the box, one baby hedgehog just born. There had been probally a large family born, but the mother had eaten them all but this one. Here is a life-sized

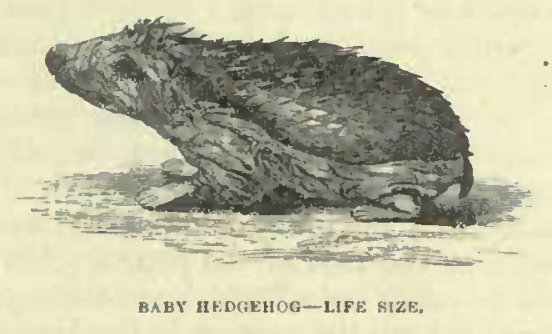

pieture of him. White was quite eorreet. The spines were soft and flexible at the birth of the little beast; they were little dumpy spikes, much resembling the incipient feathers of a young bird. Fven in the few hours the hedgehog lived these bristles grew considerably. I have nade a east of hin, and coloured it to life.

Few people, perhaps, have heard the ery of a hedgehog when caught in a steel-trap, and few would inagine that such a ery of pain and agony, somewhat resembling that of a child or a hare, could be produced by it. The flesh of the hedgehog is said to resemble chicken, and is eaten in large quantities by gipsies.

Hedgehogs are popularly said to be able to resist the effects of prussic acid, arsenic, aconite, and wourali. When studying ehemistry at Giessen with Professor Liebig I tried prussic aeid, and it was fatal to the poor hedgeliog. I have also tried hedgehogs with vipers. The viper struek the hedgelog two or tliree times in the face, where there are no bristles; the blows were well aimed, and meant to do business, as at that moment 
the hedgehog was munching up the attacking viper's tail. The liedgehog did not suffer in the least; on the contrary, he ate up the viper in the course of the night leaving not a trace of him. Pigs are said to be poison-proof against rattle-snakes' bites.-Mr. Groom Napier tells me that in America he has frequently seen a boar seize a lively rattlesnake, which it continued to devour, little heeding its furious bites, for which the boar was not afterwards the worse.

Mr. Davy lias had forty hedgrhogs at a time; he used to sell them wholesale from 8 s. to $12 \mathrm{~s}$. per dozen; he sold them cliefly to shopkeepers to sell again. Hedgehogs are very useful in kitchens, bakehouses, and gardens for destroyiug all kinds of insects, especially blackbeetles; they root in the ground for insects and beetles. He has never known ledgehogs to eat any kind of raw vegetable; they are very fond of bread and milk; he feeds them chiefly on "fat-gut" and offal; they will eat a fresh-killed mouse with avidity, and he believes they take a number of young larks from the nests on the ground. Hedgehogs do a great deal of good on ploughed cultivated land by destroying grubs and other insect pests of the farm. In the natural state they lie torpid in the winter for about four months out of the twelve. They cover themselves with leaves, grass, \&c., sometimes three or four feet deep. The hedgehog did not grub about the roots of White's plantains for the sake of eating the roots, but for the insects and grubs at the root of the plants. He would not go deep enough for "pincher bobs," which are the larvæ of the stag beetles. Pincher bobs are three years in the larval state.

Fieldfares, p. 98.-The batfolders about London take numbers of fieldfares, red-wings, and hen blackbirds, which, as a rule, are killed for eating, there being no sale for them as cage-birds. The cock blackbirds are kept alive and sold for songsters. Davy has never known either of these birds taken by a trammel net on the ground by a lark-catcher, as mentioned by White. White does not state this as a fact, but only as an anecdote.

If there had not been suitable hollies or trees the birds might by cliance take "their lodgings on the cold ground;" as a rule, fieldfares and redwings are shy. After they have been pressed for animal food and drivel to the berries by the snow, in a few days they become very poor and emaciated, and not worth powder and shot.

Fieldfares first arrive in large flocks in October with the redwing and missel-thrush. They feed on the mountain ash and any kind of berry food. 
The Monse Defr, p. 99.- My friend, Colonel Hardy, R.A., who has exhausted the history of the moose in his book, has kindly given me the following valuable note:-Mr. White's account of the Moose Deer contained in Letter XXXII. is, as is usual in his descriptions of objects of natural history coming rinder his personal notice, both graphic and accurate; in justification of which remark, as an anthority, I submit my own long acquaintance with the monarch of the North American pine forests, acquired during a sojourn of many years in the woods of Canada; and also here apologize for the introduction of a few further observations on the natural history and habits of an animal which I have always regarded with the greatest interest, and which has formed the subject of a considerable portion of my American sketches both in pen and pencil.

The moose in question when seen by White had died the morning before, having been in a languishing way for some time. This has been, and will be, I fear, the inevitable and speedy fate of every individual of this species, whether American moose or Luropean elk, attempted to be introduced alive into this country. Hence its absence from our zoological gardens. Even in the locality of its own natural habitat, the Alcine deer is difficult to keep in confinement. It requires much freedom of range. I have watched many instances in America, and kept them in a state of domestication myself; and excepting where the animals have had free access to the ontskirts of their native forest, have never known them really thrive. It is a fact well known to the Indians that the elk or moose, as the species is designated in America, seeks various slirubs and herbs as medicine for intestinal disorder to which it is remarkably subject, white oak bark being one frequently used and evidently as an astringent, mountain ash and other bitter shrubs as tonics, \&c.; whilst the fool it partakes of in a state of nature is generally of too varied a character to be afforded in confinement. Though, when in the latter state, the elk will eat with avidity a variety of roots and substances such as potatoes, beans or peas-a diet which soon kills it except when most sparingly introduced-in its native forests it browses so exclusively upon the terminal shoots of young trees and bushes as to well merit the title of woodeater.

I have never seen any sign of moose having cropped the rank grass of wild forest nieadows (beaver meadows) or the short pasture of wood-side clearings in the settlements. The only

"Vide "Forest Life in Arcadie," and "Sporting Adventures in the New World." 
exception to their coarse fure seems to be the leaves and tendrils of the yellow pond lily, in search of which delicacy, as mentioned by White, it spends much of its time in summer in wading by lake shores, as well as for the purpose of escaping its swarms of tormentors, the mosquitoes and great breeze flies. It is a frequenter of lake districts at all times, affecting low-lying fir and spruce forests interspersed with long juicy swamps, where the animal treads deeply and noiselessly on a soft enshion of sphagnum moss. Consequently, as White remarks in Letter XXXVI., it is a great swimmer, and may be frequently seen in the water crossing to and from islands. The latter localities are fiequently chosen by the females to bring up their young.

Such habits, and the power which it possesses of maintaining a long submergence beneath the surface whilst feeding on water lily tendrils, have doubtless given origin to the Indian tales of moose coming from the sea and their resorting to it again in times of great persecution, as well as to the repeated assertion of native hunters that the animal can completely lide himself from his pursuers in a lake or pond. The immense aperture of the nostril is certainly capable of being contracted, perhaps even to closing, by the flexible muscular and overlanging upper ridge. In Norway, also, as mentioned by the Rev. Mr. Barnard, its aquatic habits liave given rise to similar legends about the European elk. ${ }^{1}$

The great length of leg of the moose, which Mr. White speaks of as constituting the great distinction between it and all other deer be had ever met with, seems to be due, according to Professor Owen, to the peculiar length of the cannon bones. This peculiarity, combined with shortness of neck (generally about the same length as the head from the base of the ear to the extremity of the mou(fle), prevents the animal from grazing as other deel, or picking up anything from the ground with its long prehensile, tapir-like upper lip without difficulty, and by widely straddling its fore-legs. Seen probably in this attitude by himself or his followers, C'esar, in his Commentaries, describes the elk of the great Hercynian forest of ancient Germany as jointless-hunted by weakening trees, so that the animal, leaning against them, would break them down and ensure his own fall.

Despite the frequent assertions to be found in works of natural history concerning the ungainliness of gait and appearance of the elk, I am convinced that a nobler animal does not exist in the fir forests of either Europe or America, and that associated as it is with their grand solitudes, there is no form inore entitled

$$
1 \text { "Sport in Norway," p. } 154 .
$$


to command admiration, and indeed awe, on being first seen. From such combined feelings many a hand has been stayed from Jrawing the trigger, and many an elk has quickly disappeared scatlreless amongst the dense fir thickets through which it can worm its bulky form and spreading antlers with such wonderful facility. 'The American bull moose in its prime, in the early days of autumn, with its glossy jet-black coat, golden brown legs, and fawn coloured flanks, its great palmated loorus all cleaned fron their recent skin covering, and polished by repeated rubbing against young tree stems, is as different an animal as could be imagined from the lank dispirited figure of the moose in winter, at the conclusion of the rutting season, and when it is shorn of its head ornaments which are dropped at Christmas.

The concluding question of Mr. White, as to whether Mr. Peunant thought still that the European elk and the American moose are the same creature, may, I consider, be answered in confirmation of the latter gentleman's opinion. I have carefully examined, and taken both drawings and measurements of well grown animals of this species bred in both hemispheres, and am convineed of their identity - an opinion shared by the best German sporting authorities, and by a well known English sportsman, and correspondent of Land and Water, who has studied the question during a residence of some years in the British North American Provinces, and in Germany, in a particular forest of which country the elk is still found and strictly preserved.

I lave found more variation of the woodland reindeer of America in its distribution across the continent, than I am able to perceive as existing between the elks of the Old and New Worlds in the unimportant differences of size and shade of colour of the hair.-C. HARDy, Lieut.-Colonel, Royal Artillery.

In Land and Water, No. 134, vol. vi., Aug. 15, 1868, will be found an engraving, and a description by Colonel Hardy, of a pair of European EIlks, presented to his Royal Higlnness the Prince of Wales, by Mr. Oscar Dickson, of Gothenburg. They were kept some time at Sandringham.

Common Wren, p. 101.-_" The common wren (Troglodytes Luropecus)," writes Mr. Napier, "is prolific, but I never saw a well-authenticated instance of its laying more than ten eggs at a sitting. The wren builds a very firm, compact, and comfortable nest, which is made of a great variety of materials. I will describe six in my collection. The first is built of moss and

VOL. II.

${ }^{1}$ B. W. (Berlin). 
apple-leaves, tightly interwoven. A second, which was placed in a gooseberry-bush, is built of the twigs of that plant, intermixed with moss, and apple and ivy leaves: it has a thick lining of feathers. A third is entirely made of green moss, without a lining of feathers. A fourth is made of grass, fern-leaves, and moss, with a scanty lining of feathers. A

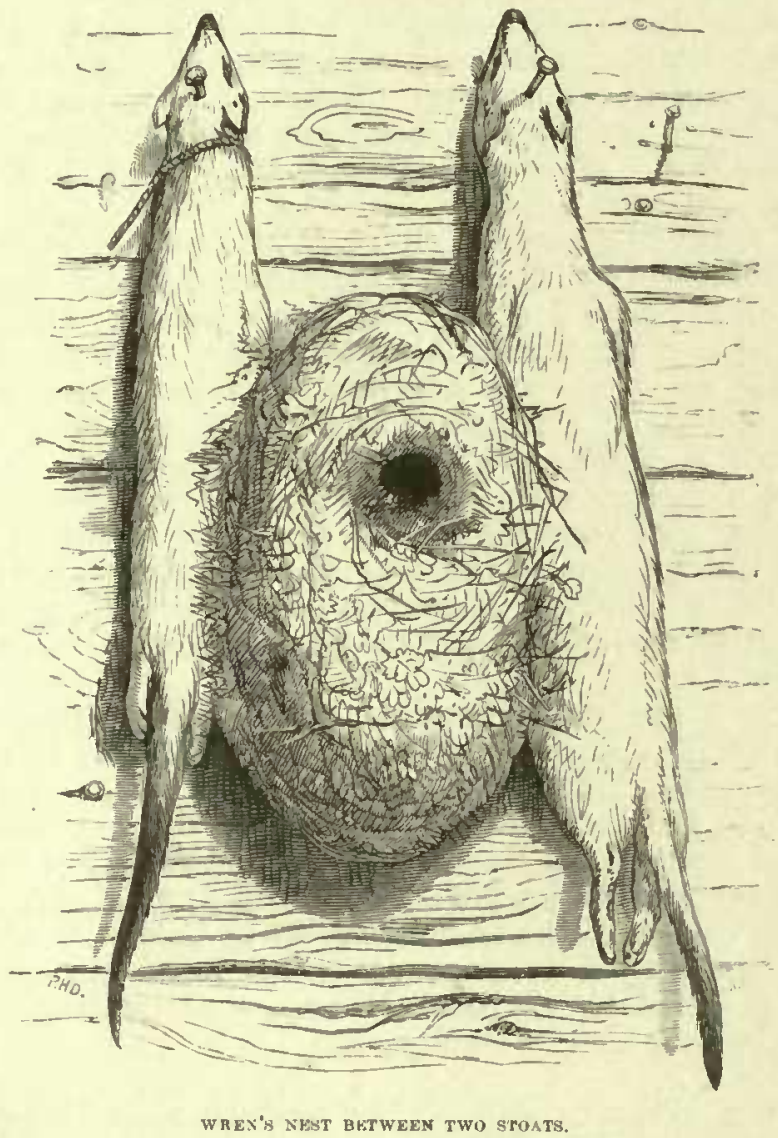

fifth is made of oak-leaves and moss, and is strengthened at the bottom with clay. A sixth is built on an old swallow's nest, which was placed in the interior of a barn. The swallow's nest is relined with moss and feathers; but it is much more open than is usual with the species. The eggs of the wren vary greatly in size. They are white, spotted with light red anct a 


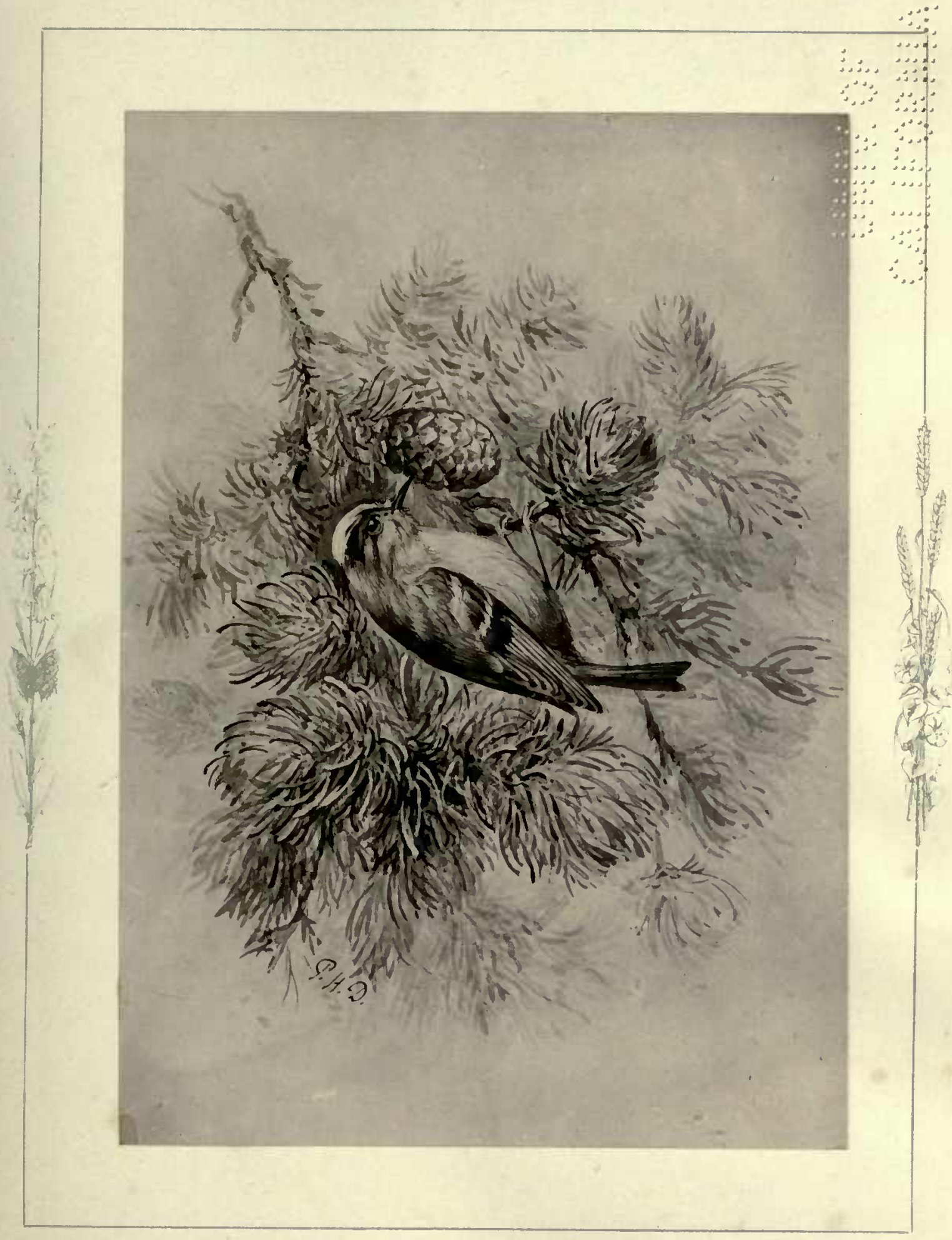

THE GOLD CRESTED WIEN 

few dots of lilne. The spots are nearly always small, and are seldom abundant."

Wrens often breed in very queer places. Lord Northwick has been good enough to give me a very good example of this as represented in the drawing opposite. The kecper at Northwick l'ark is in the habit of nailing the vermin he kills against the side of a barn or outhouse; in this instance a wren had, from some eaprice of its own, ehosen the interspace between two munmied bodies of stoats to build her nest. It will be observed that the tips of the tails are black, hence it is known that they are stoats or ermines. The nest is about six inches long, and is composed of moss leaves and fine hay, interwoven into the fur of the stoats for support. May we not infer from this that birds do not fear their enemies when dead and dry? I do not think that rooks are seared by the appearance of one of their brethren hung on a stiek as a scarecrow. I hear that in Ireland the peasants are so ragged that an old hat and jacket will not frighten birds. A friend of mine who came into an estate in Ireland ordered a searecrow to be wade of the clothes of a well-dressed Rotten-Row dandy; the birds were so unaccustomed to see such a sight, that they were quite taken aback.

The Woonlark (A. arborca), p. 101.-This bird, writes Mr. Napier, "is not generally distributed ; but in some distriets it is pretty abundant: it is an early as well as a late breeder, having eargs from April till the end of July. The nest is a careless structure nade of tine grass and a little moss. It is sometimes hardly a cup shape, but it is usually of this form, and loses its shape when an attempt is made to move it. The ground-colour of one variety of egg is yellowish white, spotted over with fine dots of ash, and a smaller number of purple brown; a second has a pale rosy tint, witl spots of the same hue of a darker shade; a third has spots of rosy brown; in a fourth the ground is obscured by minute spots of purple umber, which give a miform appearance to the eggr." "The woodlark is a very free and beantiful singer in captivity.

Whitetinoat, p. 101.- The whitethroat (C. cinerea), writes Mr. Napier, "forms its nest of grass, or the hollow stalks of the goose grass, or lady's bedstraw. It lines its nest with fine grass or roots, with occasionally a fow hairs, but wool is seldom if ever used. The nest is a most loose and eareless structure, but very diffienlt to imitate by man, for at the least touch it falls to pieces, yet the materials are so interlaeed that its construction is an interesting study. It is a summer visitor to Britain, and breeds in 
May and June, laying from four to five eggs, which vary considerably. One variety is of a greenish-white ground, with a few minute dots of ash and ochre; another resembles a small egg of the garden warbler. They are mostly spotted with ash-umber, but a set of eggs I have entirely want them, and in colour and markings resemble those of the yellow wagtail, and one has even the streak so common to this species. They are without any suspicion of ash spots, but are of a pale yellow ground. They resemble in form the type eggs of the yellow wagtail.

"The lesser whitethroat ( $C$.garrula) is also a summer visitor. It builds a more neat and compact nest than the larger species mentioned above. It is formed of the stems of goose grass, and is lined with fine roots, to which a little hair is sometimes added, and is somewhat of a cup shape. I have a nest in which a considerable portion of wool is used, which makes it one of the prettiest nests of the warblers I have seen, for in thein excellence of song is not usually united with a neat and substantial nest. The eggs of the lesser whitethroat are spotted with burnt umber and ash. The ground is lighter, and the eggs have altogether a whiter appearance than those of the whitethroat. The ground is pale yellowish-white, but occasionally yellowish ash. They are from four to five in number, and are laid in May and June."

City Sparrows, p. 103.-In November 1874, having some fishery business to transact in Billingsgate, I passed by St. Dunstan's Church. Just by the church I heard a most extraordinary noise, which at first I imagined to proceed from a steam-pipe with a sore throat. I soon, however, found that the noise proceeded from thousands of birds which had settled on two trees in the churehyard. A boy passing by happened to hit a post with a stick; the noise suddenly ceased, but a few seconds afterwards it began again as loud as ever. The birds were sparrows, and a man who was standing by told me that they generally arrived in large numbers at the end of September and took up their abode for the winter on the trees. They come there every evening at sundown till about the first or second week in February. They go off regularly every inorning at daybreak to feed, and he thought that most of them went to Tower-hill and neighbouring streets to pick up the corn dropped from the nosebags of the cab and van horses. Nobody is allowed, luckily, to disturb them. Lovers of birds should not lose the opportunity of hearing this gratuitous concert, which takes place every evening about sundown. I hear there are two trees in Sparrowpassage, close to the Angel, Islington, where the same thing 
occurs nightly. I eannot think what these city sparrows are talking about; they all talk at once, so the subject of the conversation must be important. I could not make out that they had elected a chairman. They might have been debating who was to be elected "Iord Mayor of all the Sparrows" in November. Will somebody who understands sparrow-language kindly report the debates at these meetings?

Sparrows are much used for shooting matches. The price is 2s. per dozen. Large numbers of sparrows leave Ionclon after harvest and go upon the stubbles to feed; they return again to London during the winter months, ${ }^{l}$ when farmers begin to plough in the stubble. In September there are hardly any sparrows in London. After they have been caught at and thinned several times, they become artful, and the moment they see the net they ery, "Jim, jim, jim," and are off. An old Jim is as cunning as an old man from seeing his friends so often caught in the net. Sparrows are a great pest to the Zoological Gardens, by entering into the food houses, and especially the warm honses in winter. Since the establishment of the Zoologica! Gardens in 1826, nearly fifty years ago, the sparrows have been netted, shot, and caught at all seasons; the nests also have been robbed of their young whenever and wherever they could be obtained. In spite of this constant war of extermination-for it is a war-there are probably more sparrows in the gardens at the present tinje than ever existed since the establishment of the Society. If this constant persecution or destruction of them had not been kept up, it would he utterly impossible to keep a collection of waterfowl, gallinaceous birds, or any grain-eating animal. So tame and impndent is this multitude of sparrows, that they wait in large numbers for the keepers, who go round to feed the various animals, and before he can leave the feeding trough it will be blackened by the numbers of sparrows. If not caught and destroyed, the poor animals in the gardens, especially the water-fowl, would be starved. Eightpence per' dozen is paid for sparrows; they are used us food for the serpents, falcons, and small mammalia, and are very useful, as they could not always be bought when required. Many of the smaller animals could not exist without food of this kind.

1 Mr. Bartlett, of the Zoological Gardens, does not think the sparrows go away froun London: Sparrows about provineial towns probably do go away into the stubble. Mr. Birtlett's reason for dotbting the exodus is that sparrows are of very short flight, and if they did go into the country we should see sparrows with elean feathers on their return: this we never do, the London sparrow being always a smoky, dirty-looking individual. 
Mr. Bartlett gives the London sparrow a bad name; they do a vast amount of mischief. In the early spring they collect in the streets and squares every feather and stray straw and other rubbish, witl which they build their nests, filling up generally the head of the water pipe on the top of the house; the first heavy storm washes Mr. Sparrow's nest into the rain pipe, the consequence is the house becomes flooded.

Cats' Fondness for Fish, p. 104.-The following is my account of a piscivorous cat, the property of an old fisherman at Portsnoutl, called "Rolinson Criusoe" :- " Puddles is my cat, sir, and that's why they call me 'Robinson Crusoe,' 'cause of my boat and my cat. He was the wonderfullest water cat as ever come out of 'Portsmouth harbour was 'Pnddles,' and he used to go out a-fishing with me every night. On cold nights he wonld sit in my lap while I was a-fishing. I was obligated to take him out fishing, for else he would stand and yowl and marr till I went back and catched him by the poll and shied him into the boat, and then le was quite lippy. When it was fine he nsed to stick up at the bows of the boat and sit a-watching the dogs (i.e., dog-fish). The dogs used to come alongside by thousands at a time, and when they was thick all about, he would live in and fetch them out jammed in his mouth as fast as may be, just as if they was a parcel of rats, and he did not tremble with the cold half as much as a Newfoundland dog : - he was used to it. He looked terrible wild about the head when he come up ont of the water with the dog-fish; I larnt hin the water myself. One day, when he was a kitten, I took him down to the sea to wash and brush the fleas out of him, and in a week he would swim after a feather or a cork."

My friend, Mr. Austen Layard, British Minister at Madrid, has referred me to his account of his tame fish-eating Lion. It is to be found in his "Ninevel and Babylon." Mr. Layard writes: - Osman Pasha, the general, received me with courtesy and kinduess. On my first visit he presented me with two lions; one was nearly of full size, and was well-known in the bazaars and thoroughfares of Hillah, through which he was allowed to wander mirestrained. He would also wait the coming of the kuffas or wicker boats of the fishermen, and driving away their owners, would help himself to a kind of large barbel, for which he appeared to have had a decided relish."

Cats in Rapbit-holes.-House cats that are half wild sometimes live in ralubit-holes. E. N. I. writes:- " $A$ man was engaged to kill rabbits in the high bank of an old quarry which 
is in oue of my woods. The place is a regular honeycomb of burrows, and the man carefully netted the holes betore putting in his ferrets. Imagine his surprise at seeing one of his nets carried away and go rolling down the steep incline to the bottom of the bank, and to find his captive to he a cat!"

Mr. Reed of Wick also writes:- "In one of the islands of" Orkney, where rabbits are very nunierous, the inhabitants crop short the ears of their cats to prevent them going into rabbit holes. The ears being cut very close allows the sand to get into them, which so anuoys poor puss that she never attempts a second time to poach in rabbit-warrens, which are abundant in the sandy parts of the island."

Cats Sucklivg Hares, - Many cases have been recorded in Land and Water of cats suckling rabbits, young squirrels, \&c. I agree with White, that the cat suckles these foster-children not out of affection for them, but simply to get rid of her milk. It is not at all impossible that Romulus and Remus were suckled by a wolf.

Ilouse cats are great nuisances at the Zoological Gardens. They prowl about the parks at night and easily get over or through the fences into the Gardens, frightening and disturbing the valuable pheasants and other birds by walking on the top of the cages. Mr. Partlett does lijs best to catch these cats. They are skinned and given to the eagles to eat. The skinned cats are amazingly like rabbits; when the head and paws are cut off it is difficult to tell a cat from a rabbit. On Saturdays the keepers bring the tails of the eats they have caught to the office and are paid sixpence per tail.

Most of the eats eaptured in the Gardens are full grown males, that appear to live in sheds and ont-houses. I have reason to believe the greater part of these poor cats are the result of people allowing their female cats to rear more kittens than they afterwards like to keep, and which, when they grow up, become troublesome, and are then turned adrift in the hope they may find a home. Failing this they turn wild, and become a perfect nuisance by killing and frightening all the birds and sinall animals they can find.

TuE OTTER, p. 104.-I cordially sympathise with the delight of White on examining his twenty-one-pound otter. I can, lowever, beat this animal in weight and size. In January, 1871, my friend, Dr. Norman, of Yarmouth, sent ine a magnificent otter, packed in a baby's cradle. He wrote: "I believe this otter to be the largest ever taken in East Anglia, and if well fed his weight 
would have exceeded that of any other I ever saw. Many otters have been taken in our Broad district, near the same river and its trihutary streams, which appear to be their favourite resort. A fine specimen of about 20lb. was skated down on Ormesby Broad a few days since, and inflieted a very severe wound on the hand of one of its eaptors, who got hold of the beast's tail. The marshy district in the valley of the Waveney, and espeeially near Fritton and Oulton Broads, is also a favonrite habitat of the otter. The largest authenticated specimen I find recorded is one of $27 \mathrm{lb}$. weight, and $3 \mathrm{ft}$. $8 \mathrm{in}$. long. These interesting aniinals, owing to drainage and improved cnltivation, are every year becoming more aud more searee in old Englaud."

I at once set to work to east this otter in plaster, having posed him in a graeeful attitude. The east turned out a very great sneeess, every hair being shown, and the natural expression of the face wonderfully preserved. The easting of large animals in plaster is quite a new idea, and I beg to elaim it as my own. I am not afraid of others doing this because they do not know the modus operandi; long experience and practice have taught me. This grand otter measured $4 \mathrm{ft}$. $3 \mathrm{in}$. from the tip of nose to the end of tail, the tail being $1 \mathrm{ft}$. $3 \mathrm{in}$. long; his weight was $27 \mathrm{lb}$.

When dissecting the body of the beast, I diseovered what I believe to be $\Omega$ new fact as regards the nsophagus, or gullet. Holding up the pharynx I poured down thin plaster into the stomach, which, of course, hardened, showing its full capacity; it is $9 \frac{1}{2}$ inehes long and 15 inches round, and would hold rather over three pints of fluid. The oesophagus is 19 inches long, and, strange to say, is a very small tube, the size of a half-inch gas-pipe, or about the size of one's little finger, and only one inch and three quarters round. I expeeted to find it a large dilatable tube, as in other fish-enting creatures. The best explanation that I can give of this curiously small oesophagus is that the otter chops up lis food very small with his formidable teeth before he eats it. I had a bit of this otter cooked. When boiled, the flesh is of a brown eolour, like cold boiled beef, and the flavour by no means despieable. I offered to send a slice in a letter to anybody who would like to taste it. Nobody accepted my offer. 'This east is now in my nusseum at South Keusington.

Weather axd Migrations, p. 105.-In confirmation of White's statement on this point I learn from Davy, the bird-eateher, that birds have sense and knowledge to keep in the south of England if their food is not rendy for them at their breeding- 
places inland. In fine weather during full moon, and on bright nights, birds, as a rule, come over to their time. The nightingales were very late this year (1875) in arriving, on account of the cold spring. Swallows, as a rule, come to their time, although they do not go direct to their breeding-places; they keep under the South downs, and in protected localities such as the Devil's Dyke, near Brighton, the weather is always very mild under the Devil's Dyke Hill.

PaIrivg of Birds, p. 103.-Among all migratory birds if the male or female is destroysd before the flight or arriving time is past, he or she finds a fresh mate almost immediately. This no doubt is done by the call, but when the arrival flight is ove 1 they all get settled down to their resting-places. At pairing time, if there cliance to be a roving cock or roving hen about, they rove until they find their mate. When a cock bullfinch or cock nightingale has been caught the female will find a mate in two days.

The Woodpecker.-Fligiti and Walk of Birds, p. $106 .{ }^{1}$ -As I am exceedingly fond of dissecting when not engagerl in other work, I will now proceed to describe the structure of the woodpecker, as I wish to demonstrate what admirable beauty and design may be found in the commonest objects, if only the student of natural science knows low, when, and where to look. The woodpecker I bought is the great green woodpecker (Picus viridis). According to Wood it is also called the "rain-bird," the "woodspite," "hewhole," and "woodwall." In Oxfordshire they are called "heccles," or "green aisles." The structure of this bird will, I think, form an answer to the Darwinian theory. In every respect it is most admirably suited to the duty which it has to perform in nature. In the first place, the colouring of the bird is a lovely green. What could be a better dress for a bird who lives in a wood than green? The Foresters parading at their fêtes, I observe, wear green coats. The woodpecker lias to run up the sides of trees, and whereas the tail feathers of a peacock are made to expand, so as to exhibit all the glorious colours of the rainbow, showing that nature intended that this kind of tail should be purely ornamental, so we find, on the contrary, that the tail of the woodpecker is made entirely for utility. The bird has ten feathers on its tail, Fig. A. The two centre feathers are four and a half inches long. They are as stiff as wire, ancl

1 This paragraph is quoted from my "Logbook of a Fisherman and Zoologist." Chapman and Hall, Piccadilly. VOL. II. 
pointed at the ends somewhat like the head of a spear. The tailfeathers on either side are also spear-headed, so that when the tail is expanded like a lady's fau it forms a most admirable prop, by mears of which the bird supports himself as he climbs up the

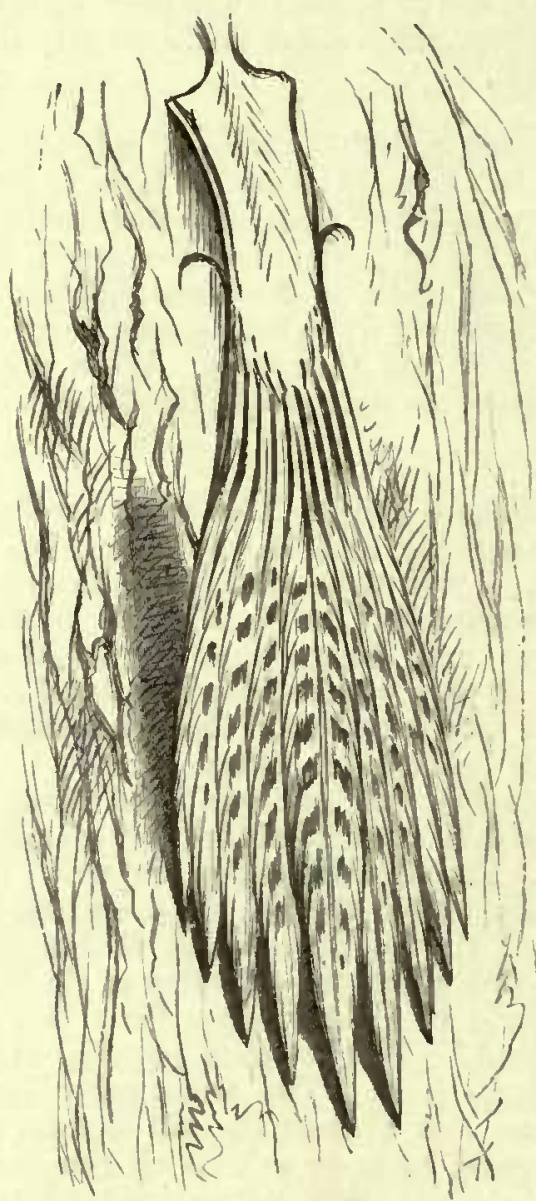

Fio. A. TAlL of woodpeckrr.

sides of the tree. Whereas the claws of the fowl are made to seratch in the earth, or the claws of the eagle for seizing its prey, we find that the claws of the woodpecker are so sharply curved that they form half a circle, Fig. B. The points 
are exceedingly sharp, so as to enable the bird to get a firm loold on the rougliness of the bark. The hind-claw is very small. The two front elaws are of unequal length, but the middle claw is so situated as almost to turn at right angles with the leg, thus preventing any chance of the bird slipping.

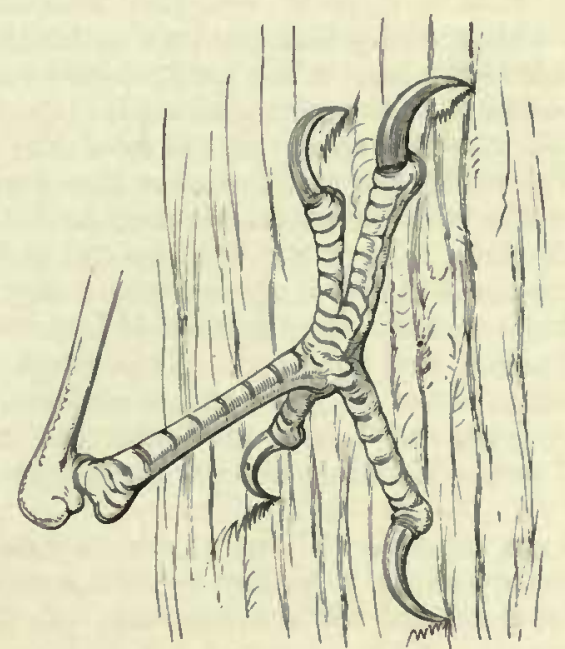

Fic. B.-Foot of woONPECker.

The tongue of the woodpecker, Fig. C., llowever, is the most remarkable piece of mechanisin about his body. If the bill be opened, and the tongne drawn out, it will be observed that it can be protruded nearly four inches from the gape of the beak. It is

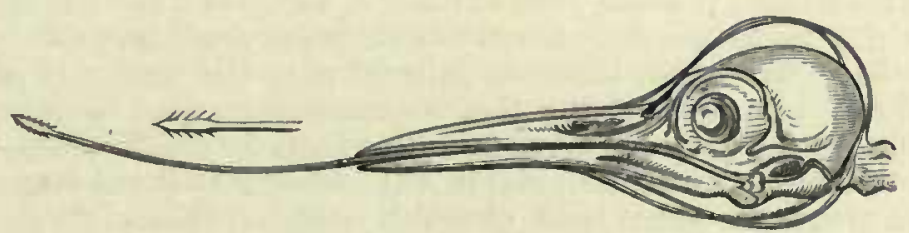

Fic. C. - Tnvave of woodpecker.

almost eylindrical, and can be pushed back into a sheath, which fits it, just as a pencil can be pushed back into a silver peneil-ease. This is very similar to the mechanism that we find in the long worm-like tongue of the great ant-eater of 
South America, but the tongue of the woodpecker presents a structure not visible in the ant-eater, for on carefully examining the top of the woodpecker's tongue, we find that it ends in a sharp horny point, and that on each side of this sliarp horny point there are some small barbs directed backwards, reminding ne somewhat of the "snatch" made of fish hooks which is used for poaching salmon. Now we find that the hyoid, or tongue-bone, which works this marvellous tongue, extends not only as far back as the base of the head, as is the casc with most birds, but is actually prolonged right over the top of the head, and is firmly fixed into the skull, at the base of the beak, on the right side. The reader can easily realize this curious structure if he imagines the tonguc-bone in his own head to be extended backwards on each side of the head to the poll. These two bones then run parallel with each other in a depression on the top of the skull, and are finally inserted into the bone of the forehead just above the right eye. This tongue of the woodpecker, therefore, may be said to be worked by two highly elastic steel springs, and I have no doubt that in life the bird is enabled to protrude and draw back his tongne with amazing celerity.

But I have not yet done with the numerous mechanisms in the lhead of the woodpecker; a further ingenions contrivance was, I believe, first described by Mr. Bownan, of Wrexhain, who writes thus :-

"In the back part of the palate," he says, "is inserted a iongitudinal groove, which tapers to a point outwards, and is fringed with stiff hairs pointing towards the throat. Without this provision it would be difficult to conceive how the bird could so easily and speedily detach its food from the barbs of the tongue as it is known to do, particularly as the groove in the palate is placed much too far backward for the tip of the former, in the natural position, even to reach it, and even if it could draw it in so far the peculiar direction of the hairs would prevent their action. We must, therefore, infer (though the motion is performed with such celerity that we can never expect to observe it), that the tongue is taken into tho mouth in a reflected pusition, like that of the frog, and that the tip of it is drawn throngh the groove, the sharp hairs of which scrape off the insects from the barbs, while the deglutition is assisted by the tubercles on the surface of the tongue during the first part of the operation of drawing it into the mouth."

The stomach of my woodpecker is simply a fleshy bag, and I was pleased to find it full of food. On opening this bag-like stomach, I discovered a mass of a black-looking substance, which 
on soaking in water, $I$ at once discerned to be black ants, in number sufficient to fill an egg cup. Here, theu, we find that the police of nature ordains that the ants should eat decaying vegetable matter, especially in fir woods, where their nests are frequently robbed for the sake of feeding young pheasants with the eggs. Mr. Jamrach imports large quantities of these eggs from the forests in Germany.

May we not also learn a practical lesson from studying the habits of the woodpecker? I frequently hear complaints that the pine forests of this country and Scotland are seriously injured by a beetle which bores into the sprouting tops of the pine-trees, and thereby does great mischief to woodland property. If the proprietors of the forests are so foolishly ignorant as to allow the woodpecker to be shot, it serves them right that their trees are injured; when in the pretty harmless woodpeckers they have valuable servants who would, without being paid for their trouble, find out these inseet pests on the pine-trees, and very quickly dig them out of their retreat by nieans of their sharp-pointed bayonet-shaped bills. Woodpeckers are getting gradually more and more scarce; owners had better take the hint at once and preserve then, otherwise woodpeckers will soon be nearly, if not quite, exterminated.

In November, 1875. I took from the stomacl of a great spotted woodpecker, shot at Halstead, in Essex, a mature caterpillar, some two inches long, of the Leopard moth. This caterpillar is three years feeding on the wood of the mountain ash and oak. Thus we see what an immense deal of good woodpeckers do in plantations.

Transport of BHins on Joard ShIP, p. 108.-The captains of vessels liave now found out neans to bring over these softbilled birds.

Exportation of Englisil Birus to New Zfaland.-On Satulday Jan. 2, 1875, the ship Tintern Abbey sailed from the East India Docks with a must valuable consignment of British birds for New Zealand. The Canterbury Acclimatisation Society had sent Mr. Bills, jun., over to England to collect British bircls to be turned out in New Zealand. Mr. Bills, who has been well trained in this matter by his father, who has been so successful in transporting birds to the antipodes, kindly invited me to inspect liis present lot previously to their being put on board ship. I found them in a room which literally speaking was choke-full of birds, and the clattering noise of the wings and feet on entering the room was very remarkable. 
The following is a list of the birds collected, and which were ready packed:

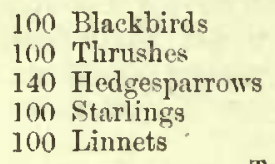

110 Goldfinches

180 Yellowhammers

100 Partridges

120 Redpoles

The birds were packed as follows:-Starlings in four cages, three feet long. Thrushes and blackbirds, in cages three feet long, having foul divisions, one bird in each division, and in all fifty cages. Linnets, twelve in a cage of eighteen inches. Yellowlıammers, twelve in a cage. Hedgesparrows, all in separate cages.

I was informed by Mr. W. Barnes, of 145 , Cannon-street, who assisted in the collection, and found the necessary accommodation while being collected, that the food taken out consisted of eighteen bushels of canary seed, liemp, flax, rape, buckwheat, wheat, cracked maize, and mawseed; Spratt's patent food, German paste, flour for bread-making; lard, treacle, and pea uneal for German paste, and four tons of sand. Thus it will be seen that the commissariat of these birds is a matter of no slight moment. The birds were all packed on board ship in a louse built on purpose, about midship, fourteen feet by twelve; there was a snall separate house for the partridges, which are nervous birds, and are apt to knock themselves about on the least provocation. Mr. Bills, of course, went witl the birds, and this was quite a sufficient guarantee that every care and attention would be shown to them.

Mr. Barnes reports (Nov. 1875) the result of this experiment as follows. Landed:-

$$
\begin{aligned}
& \text { Blackbirds and thrushes . • • • . } 191 \\
& \text { Hedgesparrows . . . . . . } 11 \\
& \text { Starlings . . • • . . . . . } 33 \\
& \text { Linnets . . . . . . } 95 \\
& \text { Goldfinches . . . . . } 110 \\
& \text { Yellowhammers . . . . . . } 180 \\
& \text { Partridges } 74 \\
& \text { Redpoles . . . . . . } 120 \\
& \text { Total . . . } 814
\end{aligned}
$$

My friend Mr. Cholmondeley, of Condover Hall, Shrewsbury, is about to go himself to the West Indies to see if he cannot bring lumming-birds home to England alive. The difficulty is to procure insect food for the voyage. Mr. Bartlett has suggested that large numbers of earwigs should be scalded and 


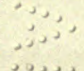

अ,

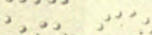

तis:

(3)

:

(x)

:

$\because \ldots, \quad, \ldots$

$\because \because 33$

$\because \ldots$

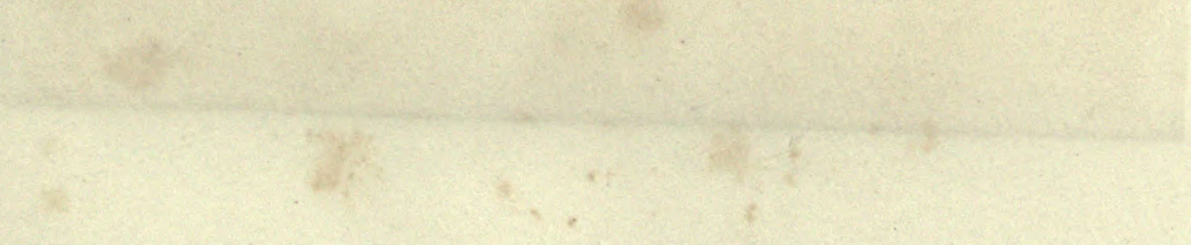




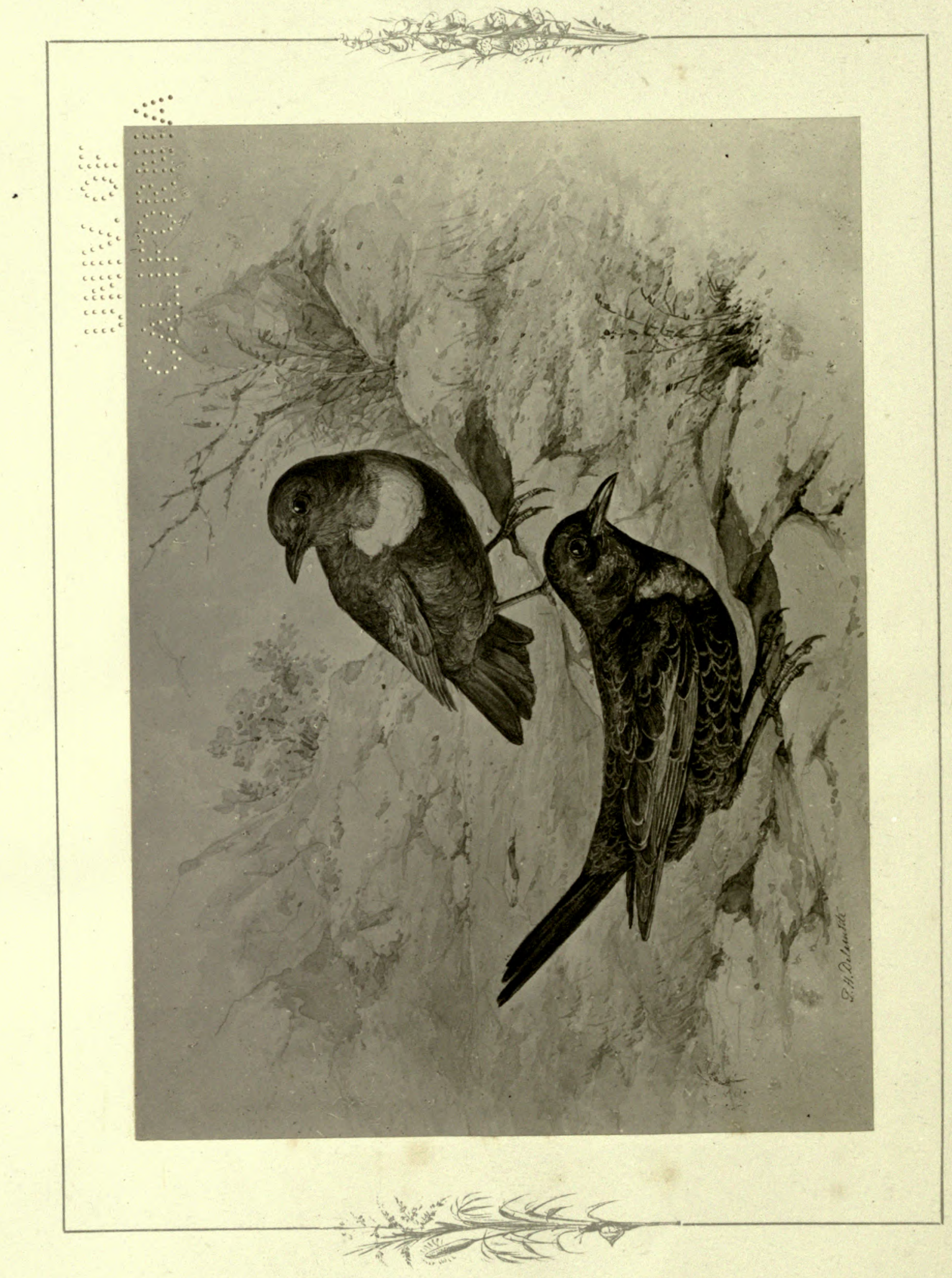

0
1
4
0
$D$
0
1
0
$Z$
$\square$ 
then dried slowly; they can afterwards be damped and mixerl up in the birds' food. Dried ants' eggs, as sold at the birdshops, might serve the same purpose. When birds are on board ship and want green meat, mustard and cress seeds should be grown on the waste sand from the cages. Mr. Clarence Bartlett lately went to India witl a large number of birds.

Risg-Ousel, p. 109.- "The Ring-Ousel," writes Mr. G. Napier, "breeds, in April, in the northern and more elevated parts of England and Scotland, as Northumberland, Yorkshire, and the Cheviot Fills. The nest resembles that of the blackbird, but is more usually built on the ground, and amongst the heather or clilfs, than the nest of the blackbird. The eggs greatly resemble those of the blackbird, but are usually a good deal smaller. They lave a larger proportion of ash-coloured spots than is common with eggs of the blackbird; but some varieties resemble then exactly, so that it would not be safe to discriminate between the species from mere appearance. The same may be said of the eggs of the redwing and fieldfare."

The Ring-Onsel has been sometimes known to breed near Derby; they are wonderful birds for monntain-ash berries; they coine from the north of Scotland; they are found in small flocks, feeding with red-wings, thrushes, and blackbirds, on any kind of berry from Uctober to March; their habits are the same as those of the blackbird; they breed in Norway and Sweden; they are caught, as a rule, off the mountain-ash; they are not uncommon in winter months; the eggs nre scarce in this country. It has been stated that the ring-ouzel departs at the end of October. Mr. Davy says that every year he has the ring-ouzel brought to him up to Christmas, and also in the early spring; he concludes that they remain here witl blackhirds and thrushes all the winter. MIr. Edon, curator of my fish museum and taxidermist, informs me that the ring-ouzel is very common about Castletown or Castleton, the peak of Derbyshire. "I was once collecting ferns on the Winnits-a name given to some rocks standing between Maur Tor, or the Shivering Mountain, and the Devil's Hole-it was there amongst these rocks that I first saw and heard the ring-ouzel ; it is very common there. I have only once known it to be seen in the neighbourhood of London and that was about four years ago, when I had one, a female, brought to me; it was shot in the neighbourhood of Kilburn Park." The ring-ouzel is said to breed every year in the west of Somerset, in the Exinoor part of the county, and in Devonshire, both on Exmoor and Dartmoor: 
"W. H." writes in Land and Watcr:-" The song of the ringonzel is hoth mellow and clear. During the spring and summer months their food consists almost entirely of insects."

Feeding Young on the Wing, p. 110.-The sand and house martin feed their young on the wing; the mother makes a clucking call, they meet in the air, and away they go again. The transfer is done in a moment; they merely catch the insect and deliver it to the young.

The late broods of martins stay in the nest till they are perfect on the wing, and then take flight and migrate with the old.

Woodcocks, p. 110.-A great game preserver wites me:"Woodcoeks' nests in this country have been carefully watched, and the eggs when protected have generally hatched out; but the young, we may venture to say, have never been seen in or upon the nest, if the dead leaves or spot chosen by the woodcock to deposit her eggs upon can be called a nest. Without doubt the woodcock removes her young to a neighbourhood where food is plentiful, but makes her nest on bare and dry ground, and where one would least expect to find it."

Various theories exist in different localities as to which wind brings woodcocks, and whether any particular quarter of the moon favours their flight; certain it is that they make their appearance every year nearly to a day, and that frost has more than anything else to do with their remaining or taking their departure.

A long correspondence took place some time since, on the subject of the woodcock carrying its young with its beak or claws. This matter is not settled yet. Professor Quekett discovered in the stomach of a woodeock some very curious-looking hairs: having examined them with a microscope, he pronounced them to be the hairs of the earthworm. These hairs can be found in the living earthworm in the hollows between the rings which form the head.

I hear from my friend Col. Maxse, Governor of Heligoland, that it is customary in that island to hang up nets across the streets at night. The woodcocks migratiug from the Continent run their heads into the meshes of the net and thus get caught.

WATER-OUSEL, p. 112.- " The dipper, or water-ouzel (Cinclus aquaticus)," Mr. Napier writes, "breeds in Yorkshire, Derbyshire, Devonshire, many parts of Wales and Scotland, and often commenees its nest early in April. The nest resembles that 
of the wood-wren, common wren, or the willow warblers, rather than the thrushes. It is generally made of moss and grass tightly woven together. One in iny collection is composed mainly of grass and the stalks of sedges, and is thickly lined witl clead leaves. The eggs are nniformly white when blown, but before this have a beautiful tinge of salmon colour. The young dippers are curious little birds, and take to the water at a rery early agre. The egrs are of a more transparent white than those of such birds as the wood-pigeon or the owl, and number from four to six."

Watel-Ousel, p. 112.-This pretty little bird is accused of eating salmon and trout eggs from the natural spawning-beds. I ann strongly of opinion lie never does anything of the kind. Here is a good witness in the bird's favour. Mr. J. H. Morsfall, of Leeds, writes me:- "I have made, at your request, a most careful exanuination of the bird, from the stomach downwards. I was pleased to find the gizzard (which is by no means very muscular) quite full. I placed it in a vessel of clean water, divided it in half, and empticd out the contents, the whole of which I passed in detail under the object-glass of a microscope. I cou'd not find the least trace of fish ova; I looked espeeially for the liorny eggcases, for these would be the most likely portions of the egg to escape digestion, but I could not find any appearance whatever of them. The contents of the gizzard consisted entirely of the hard external cases of water insects, portions of the legs with the hooks attached, and broken fragments of other portions of their bodies, intermixed with some vegetable structure and several small fragments of gravel and transparent quartz.

"T'wenty fell to my gun, just as they emerged from the spawning-beds, every one of which I at once opened from bill to gizzard. On examination, both before and after wasling, with the naked eye and under the microscope, I coukl not in one single instance discover a trace of ova, neither of case of ova, nor of the oleaginous matter which forms the contents of the case; instead of this, I found the stomach full of the larve of flies, whole and in fragments, and always more or less of fine sand. About this date I lieard of the destruction of ova in the boxes at Stormontfield by the larva of the stonctly, and it immediately occurred to me that I was destroying a most efficient assistant, and that the water-ousel was one amongst the many exquisite links constantly presenting themselves to the student of the natural listory of salmon and trout. During the formation of the spawning-bed, the salmon turns over gravel, in the interstius of which lie the larve of aquatic flies, to which the water-ousel is VOL. II. 
debarred access until so turned over by the salmon, and the more frequent the visits of this most useful bird to the newlyturned gravel the freer will the spawning-bed be from these luurtful insects. This opinion subsequent experience has confirmed, and preservers of salmon will act wisely to protect as a most able assistant the falsely-accused water-ousel." I therefore entreat fish-culturists, water bailiffs, and gamekeepers not to kill the water-ousel.

I have written on this natter many times; I urge it once more, and repeat, "Spare the water-ousel ;" he is a friend, not an enemy, to fish and fish-eulturists.

Brighton Bustards, p. 113.-Brighthelmstone is of course Brighton. The origin of the prosperity of this beautiful town was Dr. Russell's book, published in 1752 , entitled " $\Lambda$ Dissertation on the Use of Sea-water in the Diseases of the Glands, particularly the scurvy, jaundice, king's evil, leprosy, and the glandular consumption." Dr. Russell established limself at Brighton, the sea-air cured his patients, and the doctor made his fortune. I should exceedingly like to see bustards re-established on the downs. I am certain they would do well, and form a most interesting addition to the present charms of Brighton. I wish the Mayor, the residents of Brighton and its vicinity, and Sir Cordy Burrows, would take up the idea. Hustards conld be obtained from the plains of Central Europe, not far from Berlin.

Norfolk was once the liead-quarters of this magnificent bird. There are some fine specimens in the Museum at Norwich, shot between the years 1820 and 1830 .

Many interesting particulars as to Norfolk Bustards can be found in the Rev. R. Lubbock's descriptions of "The Broads and Decoys" (H. Stacey, Norwich, price eighteenpence). All naturalists would rejoice exceedingly if His Royal Highness the Prince of Wales would revive the race of Bustards on his estate at Sandringham. The country about there is admirably suited for them.

I am told they show good sport when coursed. The bustard is to my mind the "ostrich of England."

Ducks, p. 121.-My uncle, the Rev. B. Morland, rector of Shabbington, Bucks, in the middle of a large grazing country, tells me that the farmers in the district are in the habit of utilising the calves as food for early ducks. The heads, feet, and sweetbreads of the calves are sent to the London market, and the rest 
of the flesh is boiled and used to feed the young ducks; they thrive wonderfully upon it.

There is a legend in this neighbourhood that an old woman, who was bedridden, used to get a livelihood by hatching out early ducks. She had an immense bed in which she hatched out the ducks by the warmtl under the bed-clothes.

Nightingale ( $P$. luscinia), p. 122.-“ This bird," Mr. Napier writes, "breeds from the beginning of May till the middle of June. It lays from four to six eggs, which are nsually of a uniform olive brown or green, varying in shade. They are sometimes of a blue grcen, entirely covered with spots of olive brown, at other times of a elear blue green, with blood spots. The nest is commonly formed of oak or beech leaves, and grasses intermixed, and lined with tine grasses or hair; a nest $I$ have is formed almost entirely of moss, but contains a few oak-leaves and grasses; it is also lined with a few horse-hairs. The nightingale is found in Gloucestershire, Wilts, Sussex, Hants, Kent, Surrey, Middiesex, Essex, Cambridgeshire, Hunts, and many other countics. 'The first nest of the nightingale I ever found was in Sussex."

Mr. Davy informs me that the earliest place for nightingales is Welwyn in Her fordshire, where they arrive as early as the 10th of April; in other places they come usually abont the 14th. Bird-eatchers, when they go out expressly for nightingales, carry with them scraped meat and eggs, and cram the birds about two bours after they are caught, and repeat the cramming several times during the day. The old birds are sometimes very difficult to " meat off," they will put up with any punishment rather than feed. Nightingales are not known in Derby or Yorkshirc. Mr. Davy has frequently sent these birds in pairs to botli places. The late Sir Charles Slingsby used to take a dozen pairs of nightingales at a time in the hopes of acclimatising them at Knaresborough in Yorkshire. On one oceasion nightingales bred there, the keeper found a nest and eggs, but on the whole this experiment has not sueceeded. The reason why nightingales are not found in many districts, such as Scotland, Ievonshire, Cornwall, is that their proper insect food is not there. The food of the nightingale consists of small beetles and any sort of fleshy eaterpillars, not hairy caterpillars. It is stated by some that the nightingale will feed on the glowworms at night, but this is a mistake; the bird when once settled down after dark, never moves from his lodging unless disturbed. Any person by starting one or two nightingales singing in a road 
between coppices, wonld set the birds all round singing, and they will do their song several times right through.

I now give Mr. Davy's reading of the song of the nightingale. The song is conmenceil by "wheeting and liurring," which may thus be written :

"Wheet, wheet, kurr, k-lu-u-r-r-r."

The song after that commences:-

$$
\begin{aligned}
& \text { "Swoct, sweet, sweet, sweet, } \\
& \text { Jug, jug, jug, jug, jug, } \\
& \text { Swot, swot, swot, swotty." }
\end{aligned}
$$

They lie a long time on these notes, finishing up with " swotting and kurring." The song must be pronounced with great inflexions (crescendo-diminucndo, I think the lady pianists call it), especially modify the "sweet, sweet," and pronounce it in a plaintive manner. The "jug, jug, jug," is quick, like a dog barking.

Bechstein, the German naturalist, has also put the song of the nightingale into words. He writes:- "The song of the nightingale is so articulate that it may very well be written." This is what Bechstein makes of it.

$$
\begin{aligned}
& \text { "Tioû, tioû, tioû, tiou } \\
& \text { Sue tiou squa } \\
& \text { Tio, tio, tio, tio, tio, tio, tio, tex, } \\
& \text { Contio, contio, contio, contio, } \\
& \text { Tzu, tzu, tzn, tzu, tzy," }
\end{aligned}
$$

and so on for twenty more lines. I much prefer Mr. Dary's version of the nightingale's song as given above.

The following is the return of the "soft-ment" birds caught by Mr. Davy's men in April, 1873. This was a very late year for arrivals. "Gales" means nightingales:-

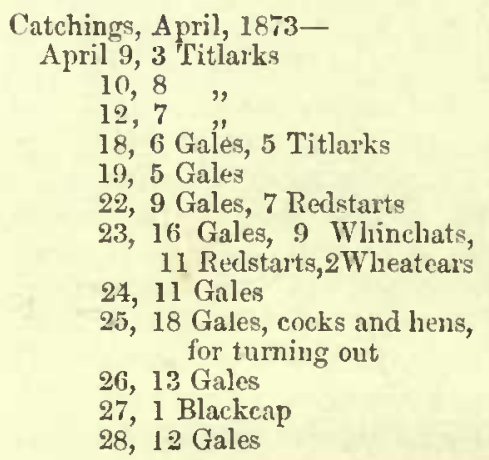

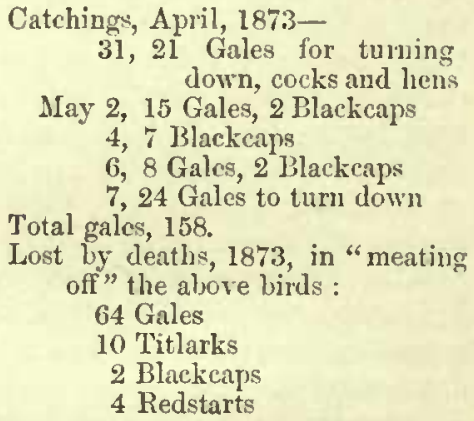

C. R. DAYY. 


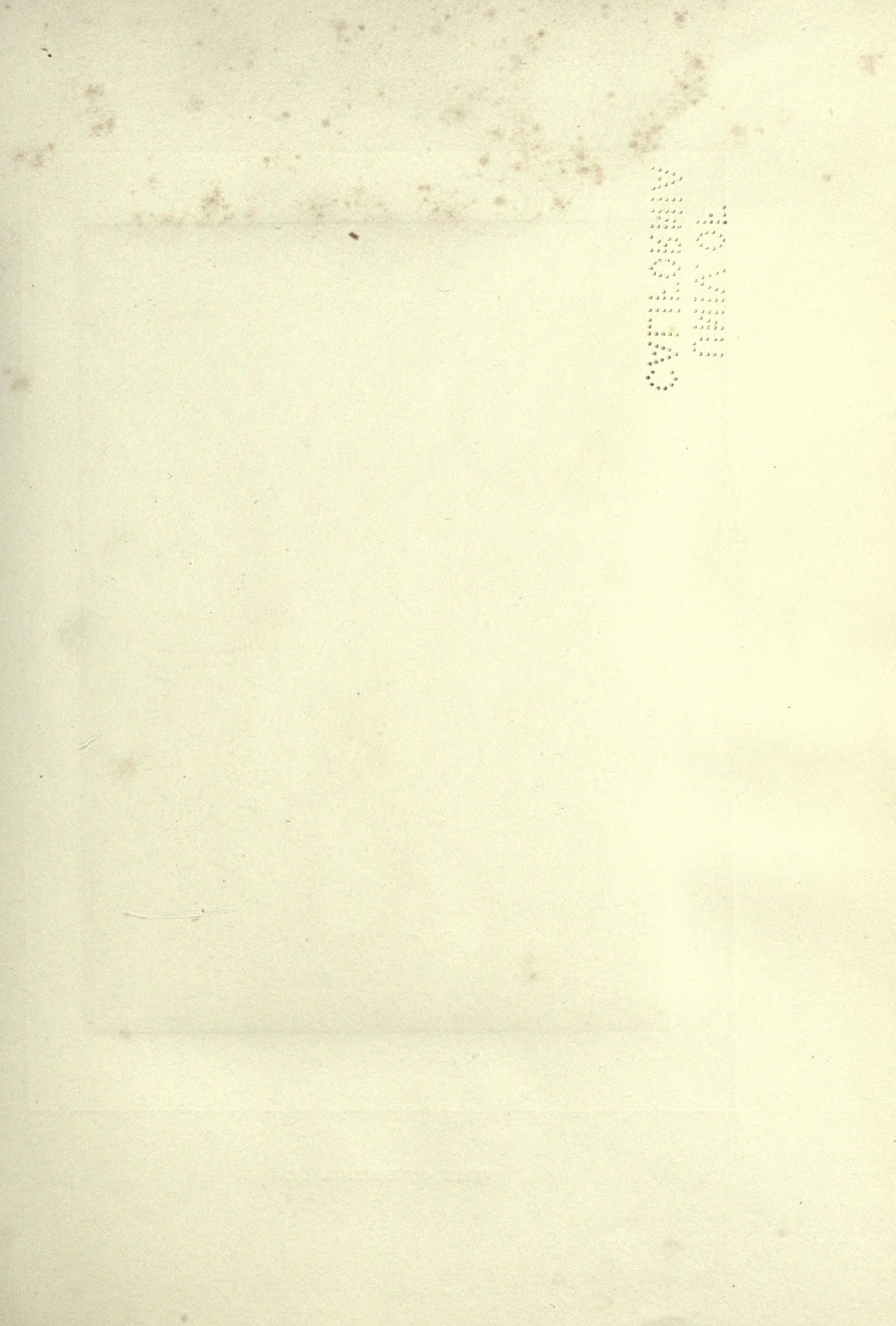




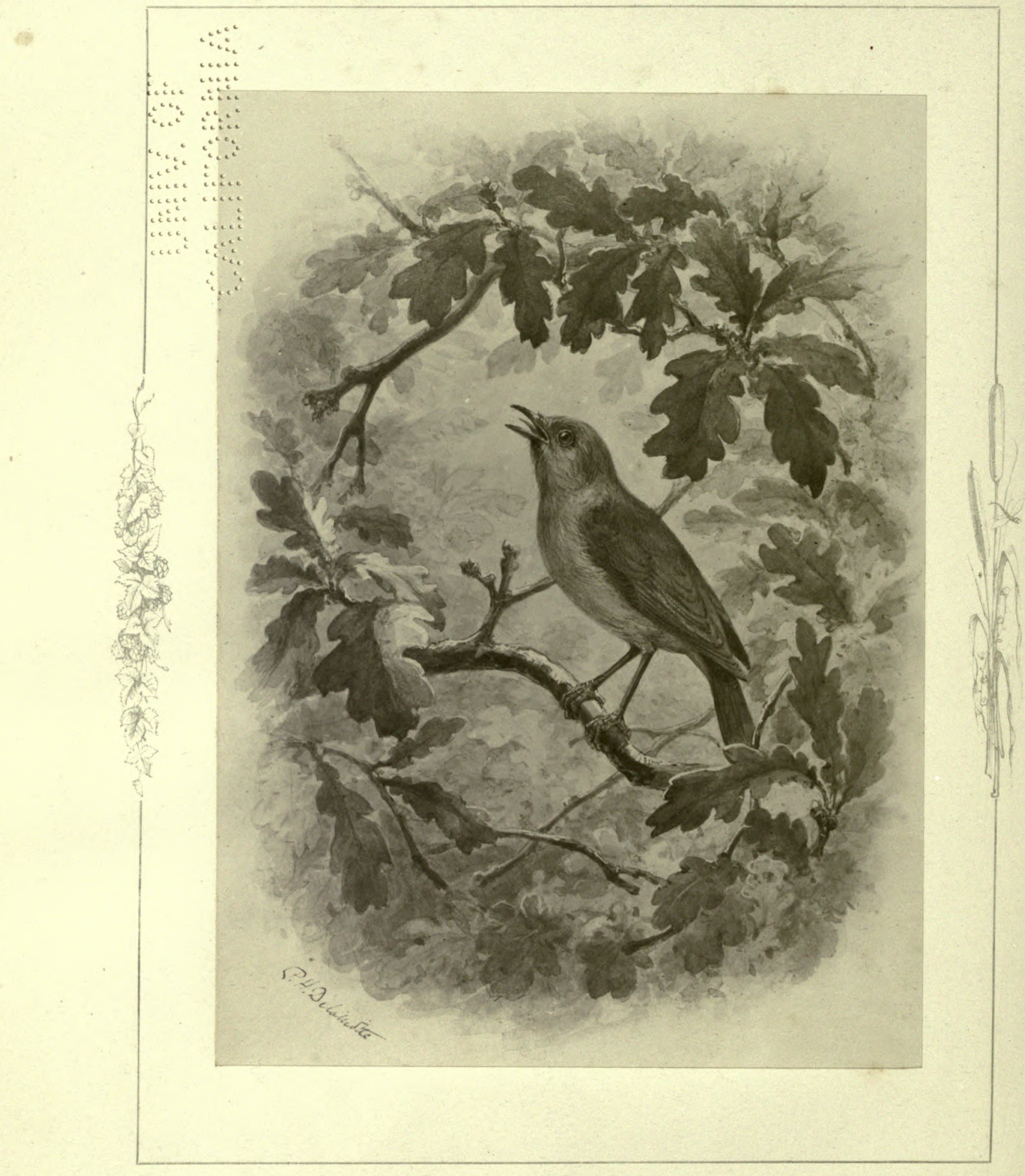

THE NIGHTINGALE 
The price of nightingales for turning out in copses is thirty shillings a dozen, coclis and hens. When "meated off," and properly caged, a nightingale is worth from five shillings to one wninea, aceording to the ruality of the song.

Mr. Keilich tells me that in Germany there are two kinds of nightingales. The larger is called a "sprossen." In size it is between the nightingale and thrush. These sprossens are common all down the Danube, and the Vistula districts. There is a great number of them about Viema. These birds are brought to England from Austria by the German bird dealers; they are known to the English bird-catchers as the thrnsh nightingale. The song is extraordinarily powerful, but its quality is not nearly so good as the British hirds. The sprossen is very seldom canght in Fngland, and is not found in France. The noise which White describes as "snapping or cracking" is called by the English bird-catchers "wheeting and kurring," the word sounds, "Kur-r-r, kur-r-r, kur-r," repeated three times, then comes a sharp "wheet, wheet," like a very sharp whistle. Nightingales build their nests about a foot from the ground, in lanes and thick hedgerows. The nests are made principally with dried oakleaves, and lined with fine dried grass. These nests when handled easily fall to pieces. The wheeting and kurring is not intended for menace; this is to delude their enemies, and entice them away from their nest. They will run and fly in front of a man along a low hedgerow. When they have enticed a man away from the nest, they will dart through the hedge and instantly double back to their nest. They are very cumning in building. Like other birds they are not frightened at cattle. 'They only wheet and kurr to mankind. No bird has any fear' or dread of cattle. Nightingales are wonderful bircls to run (or rather hop) very quickly. Tie a nightingale's wings and see if you can catch him. Nightingales' wings are always tied by catchers, and liept tied for a week. The cocks are always singing close to their nests, which are often near cottages.

This year, 1875 , two pairs of nightingales built at Highgate; one pair in the Baroness Jurdett Coutts's grounds, and another pair bred in the cemetery, on the opposite side of the lane. Numbers of people went there to hear these birds sing. They were both well looked after, and the young and old birds all escaped the bird-catchers. Nightingales return every year to the neighbourhood where they were born, and I hope, therefore, that they will again become abundant at Hanustead. Lord Mansfield's woods at Hanpstead have beell preserved the last three years, and it is not uncommon of a summer's eveniug to hear twenty or thirty nightingales singing, especially 
at early morning and twilight; they do not sing mucl in the middle of hot days. If the woods had not been preserved there would not have been one nightingale left. Nightingales are caught alnost anywhere, within a radius of twenty miles round the suburbs of London, such as Sydenham, Kew, Epping Forest, Edgeware, and Dartford. As a rule, the cocks arrive from eight to ten days before the hens, and when they arrive they take up positions, as the locality suits. They delight in hedgerows, copses, spimeys, \&c. As soon as they arrive, if the weather is mild, they commence their song, but if the weather is cold and frosty, they keep very mute. They are caught in this inanner: the birl-catcher finds a bush which they frequent, he then makes a "scrape" with a hoe, that is, he turns up the ground to draw the attention of the bird, who comes to look for insects on the fresh turned ground. He then places the trap, baited with a meal-worm. If the birds attempt to ramble away they are clriven back by pelting. A round net trap, about a foot across is used; it is baited with maggots or meal-worms placed on a pin. A very enticing bait is a "blackbeetle, belly uppermost," which is quickly seen by the bird. A pin is run through the blackbeetle and he is fastened to the cork of the trap, the playing of the legs attracts the nightingale, he "kurrs" when he sights the bait, presently down he comes, and on touching the bait is instantly netted. The "standing net" is better than the "Jack-in-the-box" trap. The bird-catcher wheets and kurrs to the nightingale and does a portion of the song, thus: "Churr, kurr, wheet;" the nightingale answers by singing, as he thinks it is the cliallenge of another nightingale-a stranger come on his beat. In the autumn nightingales do not sing, they only wheet and kurr. As soon as they get clean moulted they leave this country. It is difficult to "meat off" nightingales, that is, to make them feed. In former times a live meal-worm was put into a glass tube, just large enough to hold lim. The following is the plan now adopted. An ordinary watch-glass is placed in a smali tin dish ; underneath the glass are placed live meal-worms, which of course keep crawling about round the edges of the inside of the glass; well scraped beef and hard-boiled egg are then piled round the outside edge of the glass. The lirds seeing the worms moving about, come and peck at them, their beaks glance off the glass, and at almost every peck they get a little of the food. After they have been induced to feed, the glass is taken away and they feed themselves, and there is no further trouble.

I A trap where the net is concealed in a box. 
"Box cages" are most suitable for fresh caught nightingales; they should have thin paper pasted over the front.

ToRPIDITY, p. 120.--White is continually mentioning torpidity. In this country dormice and hedgehogs become torpid. Here is a portrait of a monkey that in White's time would probably have been said to have laid himself up torpid. This remarkable specimen (see next page) was given to me by my brother-in-law, the Iiev. H. Gordon, of Harting, near P'etersfield, with the following history :-

"In the year" 1868 this skeleton of a monkey was given me by the liev. H. Mitchell, rector of Bosham, near (hichester. It had been found at Bosham Mill. The owner of the nill, who has since left, had a monkey that disappeared. A birch tree was cut down upon the premises, and lay for some time in an adjacent carpenter's shop; and when a part of the bark was found to be luose it was detached, and the monkey's sarcophagus was revealed, as you have it in the woodcut. It was a great puzzle to me that, while the lower part of the body was so much squeezed up, the head had resisted all pressure from the growth of the tree. I thought at one time that the head had fitted into a decayed cavity of the tree; but on showing the bark adjacent to the head, some experienced connoisseurs of English timber pronounced it to have been living wood when the tree was felled, and added that the said bark was still grecn, a proof that the tree had lived within two years of 1868. At a neighbouring dinner party in 1869 , the late Bishop of Winchester, Dr. S. Wilberforce, was giving us some jokes about Darwin, and I took the opportunity of introducing this dried monkey. An illustrious mock jury was at once impanelled to try the cause of our Darwinian brother's death. No verdict, however, was returned. The Bishop thought it might be a hoax, but Sir Roderick Murchison pronounced it genuinc and remarkable."

This monkey is a Marmozet; his length is-body, six inches; tail, seven inches. The poor little creature is quite dried up into a mummy; the hair on his head and the aspect of the eyes make him look very like a small human baby mummified. The hands rest against the sides of his head as if in pain. I am afraid the poor little fellow must have crawled in and died of starvation.

It is a very remarkable thing, but there is no mark of his having been touched by any fly or other insect. The body still adheres very tight to the bark; the lower part of the body is very much crushed, but, as Mr. Mitchell remarks, the head remains intact. The appearance of the bark covering the 
monkey is quite natural; no one would suppose it concealed a mummified Marmozet.

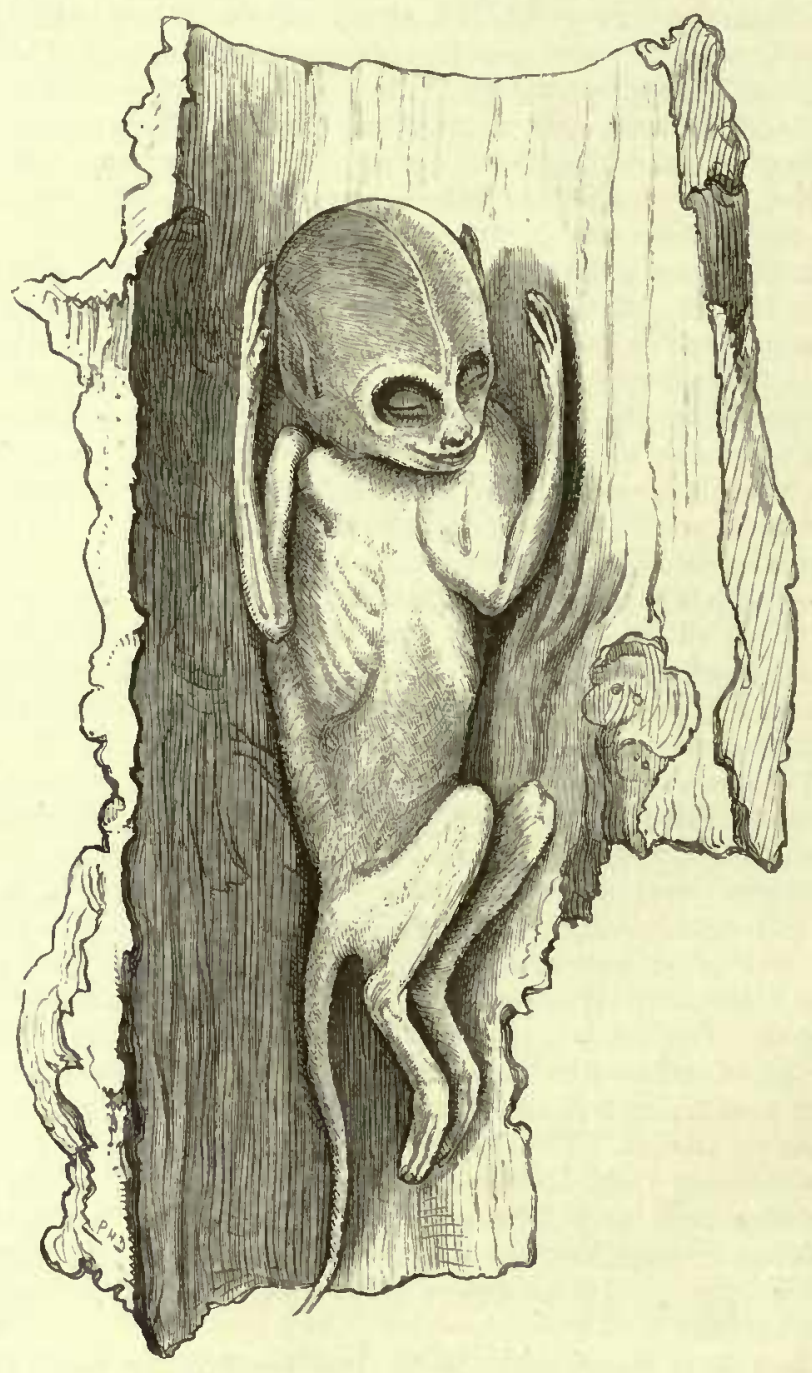

MUMMY MONKEY FOUSD IN A TRTE

'TH: HARTEST Bur, p. 124.-I think it is very possible that the irritation of these larvest bugs would cause fever. My 
friencl, the late Professor Quekett, told me that when staying in the country, he once offered a penny each to the village children for harvest bugs for the microscope; in a few minutes he was obliged to retract his offer, they were so plentiful. The liarvest bug is smaller than the mite; it can just be seen in the cracks of the skin of the hand. It sticks to the skin by means of two short arms situated above the upper legs; it feeds by means of a tubular snout. My secretary, Mr. Searle, informs me that vinegar allays the itching, and it is supposed kills them. I wish I had space to say something about the parasites which infest human beings, especially about that curious parasite the guinea-worm, or Dracunculus. Whales are troubled with parasites somewhat like bugs, with formidable hooked claws to loold on by; there are some fine specimens in my museum.

The Horse GadFly, p. 125.-When Assistant-Surgeon to the 2nd Life Guards, it was my duty to attend field-days on Wormwood Scrubs. One very hot suminer's morning my horse suddenly gave a great shudder, and seemed very much alarmed. At this moment I saw a fly buzzing about; the fly suddenly darted towards the horse's fore-legs, and almost quicker than the eye conld follow planted a white egg inside the leg. This informed me how the horse gadfly breeds. I examined the egg; it was stuck on to the hair by some glutinous material; the horse takes the eggs into his stomach by means of his tongue; they then gradually hatch out into queer-looking grubs, which fasten themselves on the sides of the horse's stomach by two hooks projecting from the mouth, and imbed themselves into the inucous coats of the stomach. I have frequently examined these; the mechanism of the hooks is most beautiful. I once found the mostrils of a roedeer entirely blocked up by these grubs. It is a very curious thing that the fly never deposits its egg on a part not accessible to the horse's tongue.

Bluebottle Flies, p. 125.-When I am at work in my dissecting room the pretty little bluebottles and other flies come to help me. It is wonderfnl how soon they find ont what is going on. Though not a bluebottle may be seen about, two or three generally arrive in a minute or two. They belp me much to make skeletons.

I once heard of a capital plan to find out the exact localc of a rat which had been poisoned and had died under the floor of a sitting-room. A live bluebottle was turned loose; he hunted about the room and at last sat down exactly over the spot where the dead rat was. He found him out by the smell. This fly VOL. II. 
saved a long carpenter's bill for pulling up the boards and putting them down again.

Elephants aNd Flies.-Regarding the balance of nature, showing how minute beings might be the destruction of gigantic things, my friend Mr. Bartlett remarks that in the native state tlies are great enemies to elephants. If an elephant gets wounded, flies deposit their eggs in the wounds; these eggs turn into maggots, and ultimately cause the death of the animal.

Flies and Cholera.-H.B. writes:- "The Italians are not the only people in the world who say flies disappear before cholera. The Welsh had, and may still have, a like idea. I remember hearing my mother say that, when this scourge first visited South Wales, it stopped at an old farm called Kidwelly in Carmarthenshire, half-way between Llanelly and Carmarthen; that it raged badly in the former town, but Carmarthen was free; and that they used to watch the flies anxiously every morning, it having been noticed that in all places where the cholera was, the flies disappeared. I also remember hearing that it was recorded in some old deeds, the great plague had halted at or near Kidwelly, but Carmarthen has since within my recollection been visited by cholera; so I conclude the charm, with which old 'Merlin' was somehow associated, has been broken."

House-FLy MagGots. - The maggots of the common house-fiy (Musca domestica) occur abundantly in horse-manure. T'he late Dr. E. Stanley, Bishop of Norwich, remarks that " the number of house-flies might be greatly lessened in large towns, if the stable-dung, in which their larvæ are chiefly supposed to feed, were kept in pits closed by trap-doors, so that the flies could not leposit their eggs in it. At Venice, where no horses are kept, it is said there are no house-flies."

Mr. Davy breeds great numbers of maggots every year: $\mathrm{He}$ begins to breed them before the arrival of the soft-billed birds, so as to have maggots ready to feed them when first caught. By these means he has been able to rear some of the rarest of the soft-meat birds. He finds that in the early spring the Hies will deposit their eggs in dead "birds," in preference to any kind of offal. They commence, as a rule, to "blow" at the nose and eyes first, and on a hot day the eggs will hatch out in fourteen or fifteen hours. The maggot, when ten days old, is ready for the birds. Maggots are used to tempt soft-meat birds to take their artificial food. When the eyes of a dead bird are once filled with fly-blows, another bluebottle coming also to deposit her eggs seems to know that the place has been already taken up; she 
therefore does not attempt to lay any more eggs, but takes her departure. To keep gentles for the winter, Mr. Davy looks out for October fly-blows. He deposits the mature nuaggot in damp sand, and buries them in bottles in the ground. He finds this plan has the effect of preventing them from changing into the ehrysalis state. By this means he is never without gentles for his birds summer anrl winter. An immense trade goes on in gentles for fishing-tackle shops; they are of nominal value in hot weather, but in early spring they are sometimes wortl one penny a dozen.

Maggots are easier of digestion by soft-meat birds than meal-worms. The skin of the meal-worms is hard, and contains much silica. Again, birds find gentles in a state of nature, but they do not find ineal-worms.

PEacocrs, p. 126.-I henr that peacocks are grand things to kill snakes and even vipers. My friend, Mr. A. D. Berrington, told me of an estate in Wales where vipers formerly abounded, and were a great nuisance till peacocks were turned down. These birds shortly killed off all the vipers. The peacock runs smartly in upon the viper, hits him harl with his beak and retires before the viper has a chance of striking with his fangs.

Calculi, p. 126.-I have three fine calculi which I obtainel from the colon of a brewer's horse. They are worn to fit each other; each is nearly the size of a cocoa-nut. The nucleus of one is a small piece of iron. I believe its composition is triplephosphate. Hair-balls from the stomachs of cows are not uncommon; I have several specimens, one especially from the stomach of a kangaroo. In the College of Surgeons is a hair calculus from the stomach of a young lady. This lady had long and beautiful hair; she was in the habit of biting off her hair and swallowing it; these hairs formed a calculus in her stomach, from which she died.

The bezoars of the ancients were taken from the true or fourth stomach of a kind of goat, the Capra Caucasic of the British Museum Catalogue.

Starlings Iroosting, p. 132.-The Rev. R. S. Baker thus writes in Land and Water :- "Near my house (Hargrave, near Kimbolton) is a fox cover of five acres, the favourite rendezvous and restintr-place of myriads of starlings, whither they have resorted now for several years in the winter months, beginning pretty early iu the autumn. They gather here every evening about an hour before dark, coming in, in flocks of various sizes, from north, east, south, and west. Unless anyone saw them they would scarcely credit the myriads which assemble. There must be 
hundreds of thousands, if not a million. And when we consider that each parish on an average harbours in the summer not more perhaps than twenty breeding pairs-say, with the young ones reared, 100 to each parish - it must take a vast number of parishes to make up the number collected at this centre every night. As a fact, I have often noticed towards evening, whell some miles away from liome, in whatever direction, flocks of starlings pass overhead in the direction of Hargrave. I may safely say that they fill a space, when all collected in one flock, of three or four acres, plane space, and fifty to a hundred fect in depth. They play all manner of aërial games round the neighbourlood for an hour before retiring to bed, and again on getting up in the morning, before dispersing to the four winds for the day. They wheel about in parties, or as a whole army, looking, in the latter case from a nile distant like a cloud, sometimes in the form of a great fish moving through the air. They gather on trees in the proximity of the cover till they are black and the branches bending down with the weight; and tle talking they do is ceaseless and deafening. At a distance it sounds exactly like the noise of a cascade pouring over rocks, and this talking they continue long after they are gone to bed; nor does it quite cense till hours after dusk. I often wonder what they talk about so fast, and all at once-very likely of the events of the day, the fine fat grubs they have enjoyed, and the dangers they have escaped. At all events, they talk to us of a good Creator who made such myriads of happy creatures, to whom existence is one round of innocent mirth and active happiness, and of keen and varied enjoyment from sunrise to sunset, summer and winter. One night I listened whether the starlings subsided, in the dead of night, into perfect stillness. It was a moonlight night, between twelve and one a.m. So far from being still, I could hear their chatter still going on from my house, 300 yards from the fox cover, and on walking up to the coverside the murnur of a million slceping starlings was curious to hear. It was like a subdued faint roar, mixed with the clear whistle of individual starlings. Starlings are possessed of great vital powers, and also muscular strength for their size. Watch them in the breeding season. Every spare minute they liave is devoted to merry chuckling, clirping, whistling, and grimacing. They scen to me to be always langhing to themselves, and they have the power of the mocking-bird in imitating other birds. I have heard a wild starling imitate for fun the plaintive cry of a lapwing to perfection, also the chatter of an angry magpie, or the caw of a carrion crow. I have a respect for the starlings. They do no harm, except pulling the thatch about, and eating a few 
cherries. They are, like rooks, insectivorous and verminivorous, and, I may say, tickivorous, for we often see them on the backs of sheep and cattle. I saw one yesterday taking a siesta on the sunuy side of a sheep's fleece, apparently wanting nothing but a pipe to complete his quict enjoyment."

T. A., in Land and Water, thus writes:-" One of the most interesting sights to be witnessed in the neighbourhood of the Broads of Norfolk, at this season of the year, is the congregation of vast numbers of starlings, which appear to be on a migratory tour to some distant land. A few days since the writer was walking in one of his marshes, about half-a-mile from one of the Broads, when his attention was attracted to one of the grandest sights he ever witnessed in the flight of birds. At first he thought he was looking at what appeared as a cloud of smoke from oue of the numerous pumping mills. It rapidly assumed many fantastic shapes, sometimes as a fluttering ribbon with frizzled ends, then as a huge balloon, and, to crown all, as a waterspout, the spout being formed by the birds descending in a silvery line, with the rapidity of rooks, to settle amongst the reeds, leaving a large mass to sail away at great altitude, in the shape of a huge ball, to some neighbouring broads. Starlings ought never to be shot; they are the farmers' best friends ; they are patterns of industry, ever doing good, excepting in the breeding season, when they pull the thatch about. They are great friends to sheep, ever on the watch to lessen the number of those pests of the sheep which tell the farmer his flock requires to undergo a dipping process."-T. A. (October 25, 1875.)

Mr. Davy informs me that Worniwood Scrubs used to be a celebrated place for birdcatching, especially for starlings. He has caught there from two to four dozen starlings at one pull of the net. 'The nets nust be laid so as to begin catching at dawn. By eleven o'clock starlings are "fed up" and are off; they go for shelter in the woods, to get out of the heat of the sun. Five or six dummies-i.e., stuffed starlings-are placed in the viets to attract the wild birds, and also one live bird on " "flur stick." The autumn is the best time to catcl starlings. They soon get very artful. It is necessary to "take a cut" at them - that is, pull the net sharp the moment they get within reach of it. 'They will often hover over the net, not making up their' minds to go in. This is the time to "cut them in." The birds about August being inostly young are not "up to the game"-that is, the net work-but they will very soon learn it and get artful. The market for starlings is for shooting matelies. 
Starlings are also extensively used for trap-shooting. The price varies from $4 s$. to $6 s$. per dozen. Directly after the breedingseason Mr. Davy would take a twenty-dozen order at two day's notice.

The Tortoise, Fish, Crocodile, Aruadillo, Hedge-HogEvidence of Design in Structure, p. 136.-White's description of his tortoise has prompted me to write as follows :- It is very interesting to observe the wonderful way in which the Creator has clothed and ornamented His various creatures. Some live in the water, some on land; some pass their time partly in the water or on land, some exist partly in the air, on the water, and on the land. All are beautifully and wonderfully constructed.

I propose now to make a few remarks on the external coverings of some of these, taking as a beginning the various modifications of horny coverings. In the scales of the fish (ilhe carp is about the best example) we find plates of thin horn, somewhat resembling (when cleaned and boiled) a portion of an ordinary horn lantern. These plates are set each into a soft pocket of the true skin, and overlap each other so as to form a complete suit of armour, giving origin, no doubt, to the idea of scale-armour, as worn by our ancestors at the time when arrows were used in battle. The scales in the fish are not all of the same size. They are beantifilly fitted, like enamel plates, on to the body, so that while they afford the most efficacious protection, they will not interfere in the least with the movements of the fish, which in many instances are exceedingly rapid. The reader should examine the mode in which the scales are fastened on (each in its own little pocket) in the case of the salmon; these scales are covered with a waterproof varnish; how and whence that comes I propose to explain at another time.

Passing on from the fish to the crocodile, we again find a scale-formed armour. The scales in this case are let into the skin in a different manner from those of the fish, and they are capable of absorbing a considerable amount of water. This I found out by soaking a crocodile's skin in water. Before the skin was soaked it was as hard and inflexible as a board. Having been soaked a few hours, it becane almost as pliable and soft as a wet towel. This is evidently an arrangement to enable the crocodile to pass his time with comfort, both in the water and out of the water. A crocodile, also, has lungs, not gills; but we never find true scales like those of a fish unaccompanied by gills. When the crocodile is basking in the sun, his scales are, of course, much harder than when they are in the 
water. This may be a protection for him against the assaults of his enemies, though I eannot imagine that Nature anticipated the discovery and use of musket balls.

If we look for scales in land animals, we shall find them more especially in the pangolin, the armadillo, and the tortoise. The pangolin's scales are very like, but yet differ from, fishscales proper, inasmuch as they are not intended to be wetted. In the armadillo we find a series of scales of peculiar shape, not let into pockets as in the fish, but each connected with its neighbour by soft skin, so that the armadillo's skin may be said to be a series of oblong-headed nails (such as are used to tack on furniture fringes) fastened into a covering which forms the skin of the animal. The armadillo has to roll himself into a ball as oceasion requires;-therefore the studs of his armour are so beautifully fitted as to size and shape that he can roll them up into a ball without the slightest appearance of a crease or wrinkle.

In the case of the armadillo, who lives under a covering of horny, flexible skin, please to observe that his backbone, and all other bones, as well as his lungs, heart, and other viscera, are all underneath this flexible roof to his body. In the tortoise we find quite another arrangement. Take a tortoise-shell and boil it, and you will find that you can pick off the scales one by one, and underneath the scales is a tenter-house of solid-formed bone. This dome-shaped house is not composed of a eontinuons mass of bone, as a tea-cup is made of a continuous plate of pottery, but rather of a series of small bones, all properly arehed to suit the original curve, and jointed togetler in a most marvellous manner. It was not possible to rivet or bolt these plates together. Mortar could not be used to bind them together, as in the case of an arch made of bricks. What then must be done? If the reader will examine for himself, he will find that the edges of each bone are deeply serrated, and that the serrations fit in such a workmanlike manner one into the other that an amount of solidity is gained which could not have been equalled if the whole dome had been cast in a solid piece.

But how is the tortoise to live in his house? Where are his ribs to go to? Let us examine. In ordinary animals the backhone forms an attachment for the ribs, and there are plenty of muscles, \&c., ontside the ribs. In the tortoise, the ribs themselves are actually used to form part of the dome or roof. By examining the inside of a tortoise-shell, the fact will at once beeome apparent. The ribs will be seen forming the girclers of this wonderful roof, and they are connected togetler by means 
of the above-mentioned plates of bones, with denticulated edges, \&c.; while the centre portion of the bone sends down an arch to form a canal in which the spinal marrow is contained.

The tortoise therefore lives inside a louse which is composed of his own ribs, formed into a dome, and he rests upon his sternum or breast-bone, which is flattened out into a broad plate to serve, first, for the attachment of the rib, and secoud, as a kind of supporting foot or basement. Can there possibly be a more beautiful piece of design than this, which combines economy of material and great strength with lightness?

We often find the same design in created things utilised for various purposes. It is therefore highly interesting to find that the same kind of denticulated suture as adopted in the tortoise is present also in our own skulls. A bony box is required to carry and protect the brain; the human skull therefore is formed of bones, each being joined to its neighbour by identically the same kind of union as that in the tortoise. There is in the human skull another meaning for this: the interposition of several lines of sutures all over the skull prevents a fracture of one of the bones of the skull spreading to its neighbour, just as the woodwork in a window-frame prevents the fracture of an individual square of glass spreading to the adjoining squares.

Structure of a Cow's Horn, p. 136.-It is often the case that in the commonest objects we may see (if we like) beautifulexamples of engineering structures. I take the anatomy of the cow's horn as a good example. In the summer of 1874 , I was inspecting the large tanneries of the Messrs. Hamlyn, at Buckfastleigh, on the River Dart, Devonshire, to see if any injury was happening therefrom to the salmon fisheries. In one of the backyards was a rnountain of the skulls and horns of cows of all sorts and kinds. Here there was a treasure worthy of investigation; so I got on to the mountain of horns and skulls, and picked out some beautiful specimens, in order to make sections, \&c.

I find that over the brain of the cow a strong roof of bone is thrown, in the shape of an arch, so as to form a substantial foundation for the horns. This roof is not solid, but is again strengthened below by a series of bony arches, that are so distributed as to form a series of hollow chambers, thus forming a structure uniting strength with lightness. The problem now is, how to fasten the horn on each side on to this buttress. The horn itself must of course be formed of horn proper, i.e., hardened hair. In the rhinoceros we find a horn composed entirely of a solid mass of what is really a bunch of laair agglutinated together; 
but this kind of horn would have been much too heavy for the cow's convenient use. What is to be done? Why, hollow out the centre of the horn, of course; but stay-this will not do, because how is the horn to be supplied with blood-vessels?in fact, how is it to grow? Let us see how it is done by the Great Designer. Cut the horn right across with a saw. and yoll will find inside another horn, only made of bone (see engraving). If the section is made about one-third of the way down the length of the horn, you will be able to pick out a piece of bone in the shape of a cone, on which, or rather round which, the horn proper has shaped itself. This bone fits the cavity with the greatest accuracy ; it is as light as the thinnest paper, and yet as

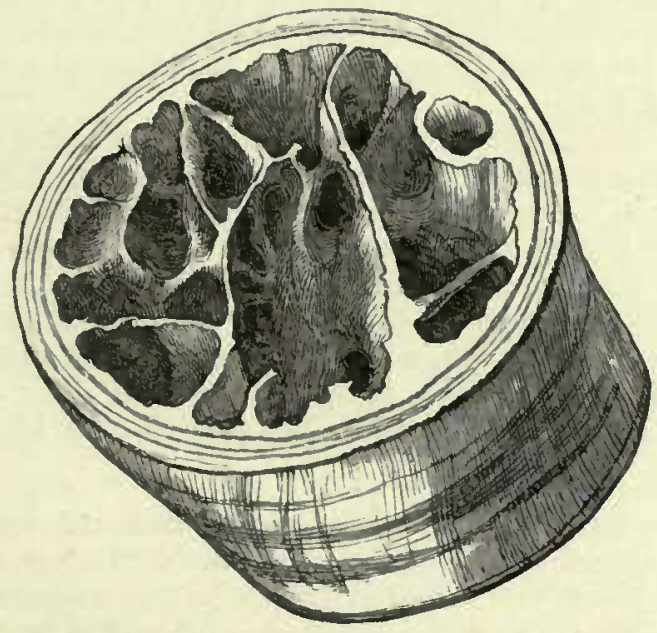

SECTION OF A COW'S HORN.

strong as a cone of tin. It is everywhere perforated with holes which in life contained the nerves, the veins, and arteries, and we know a cow has all these in her horns; nerves, proved by the fact that cows clo not like their horns touched, and that they can scratch a fly off their hides with the tip of the horn; arteries and veins, proved by the fact that a horn, when broken, will bleed, and that the horn of a living cow feels quite warm when held in the hand, besides which the nerves and arteries form a union between the internal core of bone and the external covering of horn proper.

If we now cut the rest of the horn into sections, we shall find that the inside of the bony part is really hollow, but that very vol. II. 
strong buttresses of bone are thrown (about every inch or so) across the cavity of the horn in such a manner as to give it the greatest possible support and strength. I have cut a cow's horn and skull into several sections to show these buttresses of bone, and now that the preparation is fimished I have another specimen to show that there is design and beauty in all created objects.

SPOTTED Flycatchen, p. 138.-The spotted flycatcher takes all his food upon the wing. He leaves the branch with a dart, and returns to the same spot. Its brother, the black and white flycatcher, frequents bogs in woods, and places where gnats abound. The latter bird is easily kept in confinement, becomes tame in a few days, and feeds upon eggs and bread and a little scraped becf, and an occasional meal-worm. As a rule he lives round the margins of woods and groves of trees. He is rarely found in the interior of a wood.

Mr. Bartlett informs me that a spotted llycatcher that built in the climbing stalk of a passion flower outside his bouse in the Zoological Gardens used to throw up little shining pill-like bodies that looked like blue ylass. It appears from this that flycatchers disgorge the horn-like and shining bodies of blowflies and other insects in pellets, just as an owl disgorges the pellets containing the bones and skins of the nice and rats. In the case of house-martins, bats, \&c., the hard skius of the insects are not disgorged as pellets, but pass through the digestive organs.

WHite OR BARN OWL, p. 140.--This bird is sometimes caught in gins on the tops of posts set for jays in woods. The young ones are taken from holes of trees and barns; both the young and old tame very soon; they are easily raised upon sheep's "fat-gut," with mouse or bird now and then. They eat moles in dry weather. The old birds throw their pellets outside the nest, the young ones throw them up inside. As a rule they return to the same breedingplace every year. Mr. Davy has had tbree lots of young owls from one pair of old ones out of the same nest in one season. They breed up to the end of October. Young oues are found in May. The boys in Hainault Forest used to collect owls eggs for Mr. Davy, as the eggs were of more value than young birds. The old owl kept on laying till she was found dead in the nest with a very small egg, having laid from twelve to fourteen eggs in succession in the space of three weeks. There are from three to five young in a nest, $\varepsilon$ nd sumetimes there is as much as a week's difference in the age of the young ones, some being in the "white down " and others nearly in "full feather." They fly 
very light, the wings seem arched out, and " take the wind light." Tawny or brown owls are caught in the trunks of decayed old trees in forests and large woods; they are different in their habits from the white owl, and prefer solitude. Mr. Davy has known the nest to be five feet deep in the hollow of a tree. The boys find the nests and get the young birds by taking a woollen stocking and rolling it into a loose ball; they then by means of a string bob it up and down among the young owls. The owl chicks turn on their backs and attack it with their claws; they don't seem to have sense to let go, but keep hold, and up they must come. The tawny owls are more rare than the white owls. There is abundance of the tawny owls in the New Forest. Watford is a noted place for them, especially the old trees in Lord Essex's park. This is also a wonderful place for nightingales.

There are, it is believed, no owls in Derbyshire. Squire Wright, of Osmaston, is endeavouring to establish them in a belfry on his mansion.

These useful birds may be established, if owners of property choose to do so, and the locality itself is favourable. Seven year's ago Mr. Davy sold, throngh Bailey, coachman to Mr. G. S. Bancroft, M.P. for Leeds, two nests of young barn owls, this gentleman wishing to establish them anongst the ruins of Kirkstall Abbey, near Leeds. When the young owls were strong enough they were turned loose, and being tame, were fed nightly for a time until they could find their own food and shift for themselves. Ow:ls from that time to the present can be seen at night time flying about the ruins. The monastery of Kirkstall was built in the year 1100. I am sorry to see that the ladies are making use of owls as ornaments for hats and fire-screens I saw in a shop window a lady's hat with a whole owl on it. I advise all ladies who are frightened at mice not to wear these owl bonnets, for if the owls are killed we shall soon lave a plague of mice.

When pressed for food owls will take any kind of small live thing; they lay up in store, mice, \&c., round about their nests.

Mr. Davy has had the young ones both of the long and short cared owls from the neighbourhood of Weybridge. He gets more of the long than the short-eared owls. There is always a sale for owls in London; the common fetch from two shillings; the horned ones, when matured, average $7 s .6 d$. each.

Owls will destroy pigeons under a weok old, but only when pressed for food. Stormy and wet evenings keep the mice from moving about; so owls work very hard in wet weather. A ealm, gloony night is the time for owls. 
An unfortunate misprint once sent a number of "Sunday out" people of Carlisle to the house of a valued correspondent of Land and Water. It appeared from the newspaper that there were three hundred owls feeding in the front of his lawn; this misstatement was accounted for by the fact that when the paper was being printed off the letter " $f$ " feil out in front of the word "owls," which, of course, should have been three hundred fowts.

An owl-call can be made thus: Bend up all the fingers of the right hand, elasp then tight with the fingers of the left, leaving a hollow; crook the two thumbs so as to leave a crack: blow sharp into the hollow. The call will act better if the hands are wetted. I learnt this from a jagd-meister in a forest near Giessen, when studying chemistry there with Professor Liehig. This jagd-meister used to conceal himself in a bush and call up the poor roe deer to be shot, with what he calls a "geiss blat," or roe-deer call. It was made with tin, like the stop of a bassoon.

At page 124 White says his "owls hoot in B flat." I really wish that some good musician would go to the Zoological Gardens and put into writing the various notes sounded by the animals and birds. In April 1875 I made a splendid cast of an elephant's trunk, also casts of sections of it. The trunk is used by its owner as a musical instrument. Visitors at the Zoological Gardens may often have heard a curious musical trumpeting by the female elephant when she is eating her fresh hay. As I was anxions to know what this note was in unusic, my friend Mr. C. H. Walker, organist of the Rev. Mr. Stuart's church, Munster-square, has kindly been up to see what he could make of it; he has hit it off exactly, and has played it to me on Mr. Stuart's beautiful organ. He tells me it is the lowest $A$ in the bass on an organ which goes down to double C. He uses the "Bourdon" stop coupled with the double open diapason on the great organ. Mr. Walker tells me that the higher note of the elephant when trumpeting is $\mathbf{C}$ sharp. The inusical note of the elepliant when eating is almost exactly imitated by striking gently and continuously and simultaneously the two lowest $\mathrm{A} A$ in the base on an ordinary piano. Reader, try it.

Mortaitity among Martisis from Parasites, p. 142.-The Rev. F. O. Morris thus writes in Land and Water:-I received the following the other day from Lient.-Colonel Ward, of Bannerdown House, Wiltshire, dating from Rossiniere, Canton Vaud, Switzerland :- "Having only recently seen in the Times of some time ago your letter on the mortality amorg martins, and having observed 
for several years the habits of birds, I think it is in a great mensure dne to that dreadful pest of the martin, the little insect or fly called Itenopterix hirundinis. My attention was first called to the fact about twenty years ago when I was in Melrose Abbey, where the ground was literally strewed with dead martins, without apparently any injury, and all in good condition. While I was examining one I noticed a martin fly by me, and all round the place, as if he were mad, and in his carcer he came against the wall and fell dead. I picked him up, and in an instant my hands were covered with this horrible insect, whose feet are so holding that it was difficult to dislodge them. I have several times observed the same thing at my place in Wiltshire, and found that before the body is cold these insects leave it. I cannot help thinking that this is the cause of the mortality, though perhaps not the sole cause. Last summer I did not see a martin in this place, though there was an abundance of swifts and swallows this year,-even at this moment martins are flying in hundreds ?" [I can hardly myself think the wliole of the mortality annong the martins has been caused by the parasite mentioned, for I have often seen them on dead martins, and to the best of nuy recollection some time after the birds have been dead. No doubt they may then sometimes creep all the more closely under the feathers, and so become invisible. I saw none in any of those birds that I picked up dead here this year.].-F. O. Monris.

These parasites are mostly found in the birds in autumn, just before they migrate. When they arrive in the spring they liave no parasites. The parasites are probably bred in the old nests in which sometimes as many as three broods-from fifteen to eighteen young ones-from one pair of old birds have been produeed in the course of one season.

The Cilougri, p. 144.-Numbers of Cornish choughts are sent yearly from Plymouth to London for Mr. Davy. They are in great demand, buyers for them are at all times to be found; he has paid as much as one to two pounds per pair for young birds. These birds are very much sought after. They are very cunning in building their nests among cliffs and dangerous rocks; the nests are made of small branches or sticks with a lining of wool or soft subtance. They are good imitating birds, and may be made to talk like n jackdaw. The ehoughs are now very rare round Beaehy Head, and, like the ravens in the Isle of Wight, are nearly extinct.

Stone-chat, p. 144.- "The Stone-chat (Sylvia mibieola)," Mr. Napier writes, "builds on the ground, at the bottom of furze, 
hawthorn or heath-bushes. The nest is composed of moss and grass intermixed, and is lined with feathers and a little hair, but it is usually a very loose structure. One in my collection has a lining of fine grasses under the feathers. The eggs are of a pale green, faintly spotted with buff colonr; they are sometimes almost spotless; at other times the spots are gathered towards the large end. They often have a distinctly marked zone, and a few distinct dots of a darker shade of the same colour. They are laid during May and June; the number is five or six.

Whin-cilat.-The Whin-chat (S. rubetra) "makes a nest of moss and grass. The lining consists of the latter material, with a few horse or cow-hairs added. One nest I have is almost entirely composed of moss. The egogs are of a clear, deep greenish blue, sometimes unspotted; at other times more or less marked with very small indistinct spots of buff. They are five or six in number, and are laid from the middle of May to the end of June. The nest is commonly placed on the ground under a whin or hawthorn-bush, hid amongst grass or other herbage, and is difficult to find."

The whin-chat, although said to remain the whole year, arrives in the spring and departs in September. Neither Mr. Davy nor any of his men ever knew an instance of a whinchat being taken in the winter months. The furzechat, or stonechat, does stay the whole winter. The whinchat nests on the ground, and the cocks and hens arrive at the same time. The furzechat breeds in the furze and is very conmon.

Sheep IN Australia, p. 152.-Mr. J. C. Sutherland, who has farmed sheep in Tasmania, tells me that sheep were first introduced into New South Wales not more than one hundred years ago, by a man of the name of McArthur. The sheep originally introduced were the merino of the purest breed. At this present time they have crossed the merino with Leicesters, growing a much heavier sheep and coarser wool. They made this cross leeause the original breed were getting too small and the wool too fine, the coarse wool now fetches as much in the London inarkets as did the fine wool formerly.

I am told that when a lamb dies, if the shepherd takes off its skin and sews it on to the body of another lamb, the nother recognising the smell of its own lamb allows the foster-lamb to suck. This confirms White's idea that the animals know eaeh other by the smell nore than by sight. When Fortnne was travelling in China to collect tea-seeds for the Indian Government he spoke the language so well that he passed muster 
anong them, but the dogs recognised him by the smell and barked at him.

As many as thirty to forty thousand sleep are sometimes assembled at the Carlisle sheep-markets, on a plain known as Scars. The shepherds seem to know their sheep by their faces.

WEATHER.-Apropos of sheep foretelling sudden changes in the weather, I liave heard the following:-A Professor, learned in meteorology, was examining Stonehenge; a shepherd came up and told lim if he did not make haste lome he would get wet through. There being no sign of rain at the time, the professor gave him a fee to tell him how he knew. He answered, "Now, ye see that when that old ram rubs his ear against yon big stone, I always know it's going to be wet."

Goats.-Mr. A. Sutherland, who has lived a long time in California, informs me that goats are kept in the runs with the sheep, the reason being that wherever goats are, no infection of scab or anything else will attack the sheep. In Australia they do not use goats, but there is a sheep's scab-inspector, and if any sheepfarmer removes his infected sheep to another run he is fined $50 l$. for the first offence and $100 l$. for the second.

Sheep often resemble goats very much in external appearance. My friend, Mr. Wolff, the well-known animal-painter, told me that the best test to know the difference between a goat and a sheep is that a goat always cocks his tail up in the air, whereas a sheep carries it depressed.

As regards the wild type of goats, "Zoophilus," in Land and Water, renarks that the original parentage of the raee of tame goats is the Capra Cavcasia; he remarks, that the original subjugation of this animal is ante-historical as usual, and the numerous representations of goats and sheep on the Ninevel sculptures exhibit the breeds of them much as we find them still in the same countries.

VirgiL's Hruundo, p. 156.-My friend, Mr. Edward Karslake, writes:- "I agree with White in thinking that 'hirundo' is a swallow, not a martin. It is metaphorically a flying-fish -rondine (hirundo-hirondine-rondine) and according to the descriptions of flying-fish which 1 have read, they turu and twist about like a swallow.

"Virgil would naturally think 'nigra' a sufficiently accurate description as to colour. If you had found fault, he would have said, 'I'm a poet, not an ornithologist.'

"It is perhaps a little singular that so accurate an observer as 
White does not notice that his quotation is not in the least applicable to an English swallow. What would 'Jeames' and 'Blazes,' or even the groom of the chamber, say if they saw a swallow in the entrance hall of Buckingham Palace? Or, locate our swallow (say) at Blenheim. She could but take a long flight along the façade of the edifice, and then fly off about a mile, to the lakes or ponds. But Virgil is thinking of a Roman nobleman's villa, such as is described (I may say photographed) by Pliny the younger, in a celebrated letter, the villa at Cono. Here you have a number of detached buildings: a dining-room, where people lie next the wall comfortably on sofas, while the slaves bring them their meat and drink from the open cloor; then the eubieula, then a little shrubbery of myrtles, then a cold bath, then some box-trees or planes, then a fish-pond, then a porticus, a covered gallery somewhat like the cloisters at Christ Church, or Magdalen, Oxford, or those at Hampton Court.

"What swallow ever flew along the porticibus viacuis of an English house?

"Horace thus describes the use of the Roman porticus:-

'Nulla decempedis

Metata privatis opacam

Porticus excipielbat Arcton.'

and Juvenal writes:-

'Balnea sexcentis et pluris porticus, in quâ

Gestetur dominus, quoties pluit, anne serenun

Expectet, spargatque luto jumenta recenti ?

Hic potius, namque hic munda nitet ungula mulre.

"As to the dining-room:-

'Parte aliâ longis Numidarum fulta columnis,

Surgat, et algentem capiat cœnatio solem.'

i.c., let it have a northern aspect.

"It may be wortl your while to point out in your note the inapplicability of Virgil's simile to our architecture. 'Lustrat' is as well rendered by 'explores' as by any other one English word. The bird makes its way into every nook, crevice, and crauny of the property, flying zig-zag round buildings, shrubberies, tall trees, and then flitting across fish-ponds, open baths." \&c.

Britisir Migratory Birus in Africa.--Writing of the Oases in the African Sahára, the Rev. H. B. Tristram states, in the Ilins (1859, p. 278):- "Here are the winter quarters of many of our summer visitants. The ehiff-chaff, willow-wren, and whitethroat hop on every twig in the gardens shadowed by the 
never-failing palm. The swallow and window martin thread the lanes and sport over the mouths of the wells in pursuit of the swarming mosquitos; the hoopoe solemnly stalks on every dunglill, a cherished and respected guest. These peaceful retreats seem to be rarely visited by any raptor more formidable than the kestrel, or little owl (Athene numida)." Again :- "A few pairs of swallows (Hirundo rustica) remained all the winter in each oasis; but none of those observed were in mature plumage, and I therefore presume that it is only the younger and weaker birds who stay behind. The Arabs informed me that for one swallow they have in winter they liave twenty in summer, and that they usually retire about the end of November, returning in February. Certainly very few had arrived by the end of February, though in the beginning of that month I saw myriads on the wing at Bishra, which must have remained for some time in that neighbourhood, as they did not reappear in any considerable numbers in Tunis till the beginning of March. But throughout the whole winter a few were to be seen wherever there was water or marsh. The natives are perfectly familiar with the fact of the migration of vast flocks to the south, which all go, as they say, to Timbuctoo, the El Dorado of Arab and swallow. A few pairs of the martin (H. urbica) may everywhere be seen throughout the winter, while in summer, I am told, there is not a hovel without several building in the corners of the doorways, where their nests may geverally be seen. Those which I shot were in immature plumage. Sand martins (H. riparia) do not appear to winter in the Saliára, and can only, I imagine, be stragglers there at any time, as the weeds and oases afford them but few conveniences for nidification. Both the white-bellied swift (Cypselus melba) and the common swift (C. apus) resort to the cliff's and the mcsque-towers for nidification, but, unlike the swallow and martin, retire altogether in winter to still more southern regions. The common swift had not left El Aghouat during the first week in November."

Migratory Birds leaving the Soutil Coast.-Mr. G. D. liowley, of Brighton, writes in the Ibis, No. V. p. 101 :- " Living on the south coast in spring and autumn, I have good opportunities of marking the arrival and departure of some birds. I have seen the swallows (Hirundo), over the sea, actually arrive and pass straight inland withont a pause or the least show of weariness. Not so the chiff-chaffs and willow-wrens, which stay about the shingle at first till they recover their strength. At least I have seen them at five o'clock on a spring morning within a few yards of the waves. In autumn, on certain days VOL. II. 
(varying according to the wind), the gardens about Brighton are full of ring-ouzels, chiff-chaffs, willow-wrens, vedstarts; on the Downs are wheatears; in the air goldfinches, greenfinclies, swallows, \&c. I have stood and watched these birds early on a fine morning (for birds of the above kinds do not fly in clondy, dnll days), going in continuous streams down to the sea, following one another as surely in the same direction as if going by a mariner's compass. The Roman augurs were not quite so absurd perhaps as one might at first imagine; a great many indications may be gathered from the flight of birds. Their motions appear to the common observer to be guided by chance, but the ornithologist knows that each bird he sees is employed on some particular. business, and can interpret its actions. Birds always travel by night across the sea, working their way along the coast till a proper wind is blowing, and flying against any light which may appear on the shore. In the days of the old watchmen at Brighton, small birds used frequently to fly aguinst the lanterns which they carried." As a general rule there is no time comparable to the early morning for studying the habits of wild creatures.

Swans, p. 167.-Mr. Barnwell's swan establishment is sitnated in the garden of St. Giles's Hospital, Norwich ; a most important and noble charity founded by Walter de Suffield, Bishop of Norwich (died, 1257), for the support of four chaplains to celebrate divine service, and to pray for his soul; also to be an asylum for the aged, decrepit, and infirm clergy of the diocese, and to support thirteen old people.

There are several persons who have the right of pasturage of swans, on the river, in the neighbourhood of Norwich, such as the Bishop, the Duke of Norfolk, Lord Stafford, Lord Oxford, Sir 'T'. Beauchamp, the trustees of the great hospital, and the Mayor and Corporation, \&c.,\&c. The young cygnets are caught from the river the second week in August, and, on an average, from one hundred to one hundred and thirty are brought into the pond. Their food consists of the best barley, cut grass, and cabbagres. The barley is placed in a trough which floats up and down in the water, between two posts. The barley is saturated in water for about twelve hours before it is given to the swans, and each swan while fatting eats about one coomb, that is, half-a-quarter of barley. The green meat is thrown on to the top of the water, and the birds " nibble" it off. They are fat and in the best condition from October to Christmas, when they are sold. After that they begin to fall off, even as much as two pounds in a fortnight. They do not assume their white feathers till the month of 
February; and in January they refuse their food and will not fat any more. They weigh, with their feathers, from twenty to thirty pounds. They are exceedingly good eating; the taste being between hare and wild duck, with a dash of venison. The soup made of the giblets is exceedingly good.

How to Cook a Swax.

Take three pounds of beef, beat fine in a mortar,

Put it into the swan-that is, when you've caught her.

Some pepper, salt, mace, some nutmeg, an onion,

Will lieirhten the flavour in gournand's opinion.

Then tie it up tiglit with a small piece of tape,

That the gravy and other things may not escape.

A meal paste (rather stiff) should be laid on the breast,

And sone whitey brown paper should cover the rest.

Fifteel minutes at least, ere the swan you take down,

Pull the paste off the bircl that the breast may get brown.

\section{The Gravy.}

To a gravy of beef (good and strong) I opine,

You'll be right if you add half a pint of port wine,

Pour this througl the swan-yes, quite through the belly,

Then serve the whole up with some hot currant jelly.

$$
\text { N.B. - The swan must not be skinned. }
$$

Molns, p. 167.-The following is a quotation from my "Logbook of a Fisherman and Zoologist":- "After dinner we went round the sweetstuff and tny booths in the street, and the vicar, my brother-in-law, the Rev. H. Gordon, of Harting, Petersfield, Hants, introduced ne to a merchant of gingerbread-nuts, who was a great authority on moles. He tends cows for a contractor who keeps a great many of these animals to make concentrated milk for the navy. The moles are of great service; they eat up the worms which eat the grass, and wherever the moles have been afterwards the grass grows there very luxuriantly. When the moles have eaten all the grubs and worms in a certain space, they migrate to another, and repeat their gratuitous work. The grass where the moles have been is always the best for the cows. I think it would puzzle even Mr. Darwin, or even the Right Hon. G. Ward Hunt, First Lord of the Admiralty, to connect the health of British seamen with the poor despised moles, if they did not know the facts."

M. Carl Vogt relates an instance of a landed proprietor in France who destroyed every mole upon his property. The next season his fields were ravaged with wire-worms, and his crops totally destroyed. He then purchased moles of his neighbours and preserved them as his best friends."

In August 1875, when at Mr. Burr's, at Aldermaston Park, Reading, I endeavoured to smoke some moles out of their runs. 
The Squire had not one of Mr. Bateson's vermin annililators, by means of which sulphur sinoke ean be pumped into ratholes. I had fancied that the smoke I intended to pump in would show me the run of the moles' burrowings. I therefore got from the gardener the apparatus for smoking his plants. I found some fresh molehills, I knocked off the loose earth from the top of a molehill, and then pumped into the run strong smoke made from tobaceo and brown-paper. The smoke iminediately came out of several of the moles' hillocks, which smoked like young volcanoes. I then traced out Mr. Mole's tunnels by means of a spud, but I had not power enough in the bellows to blow in the smoke a long way so as to start "the little gentleman in black." Mr. Davy informed me that directly the smoke is blown in, Mr. Mole "takes his hook," and while the smoke ascends through the mole-hills he works himself deep into the earth. Cunning rascals, these moles! I shall give them another turn some other day. The Squire's keeper informed me that the moles invariably worked at eight, twelve, and four regularly every day. He took me some little distanee to a footpath running across the park, and pointed out how the mole literally had two "diggins," or castles, one on each side of the path, and that he had one tunnel to cross this path, just like the passage in the Houses of Parliament that connects the House of Lords with the House of Commons.

Moles certainly have eyes. Blow the fur backwards, and two very tiny black specks can be seen; these are the eyes. The optic nerves are small, but they exist. A dried mole should be taken off the bushes where the

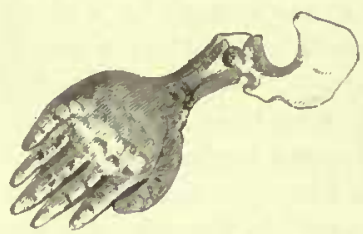

DIGGING PAW OF THE MOLE mole-catchers have hanged moles. If the dry skin is carefully cut off the head, the orifices of the eyes will be easily seen-the anatomy of this most interesting and curious little beast will also be readily made out. Soak one of these dry moles in warm water-cut off the skin with scissors, and a skeleton can be easily made.

The skeleton of the mole is one of the most striking instances of structure designedly adapted to habits in the whole animal kingdon. The little lancet-like teeth are specially beautiful. Here is the wonderful digging paw of the mole; it is worked by very powerrul muscles.

Hooped Crow, p. 170.- The hooded crow (Corvus cornix) does not often breed in the South of England. Orkney and Shetland 
…도

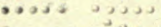

¿....

$\because \ldots$,

$\because \therefore$ 


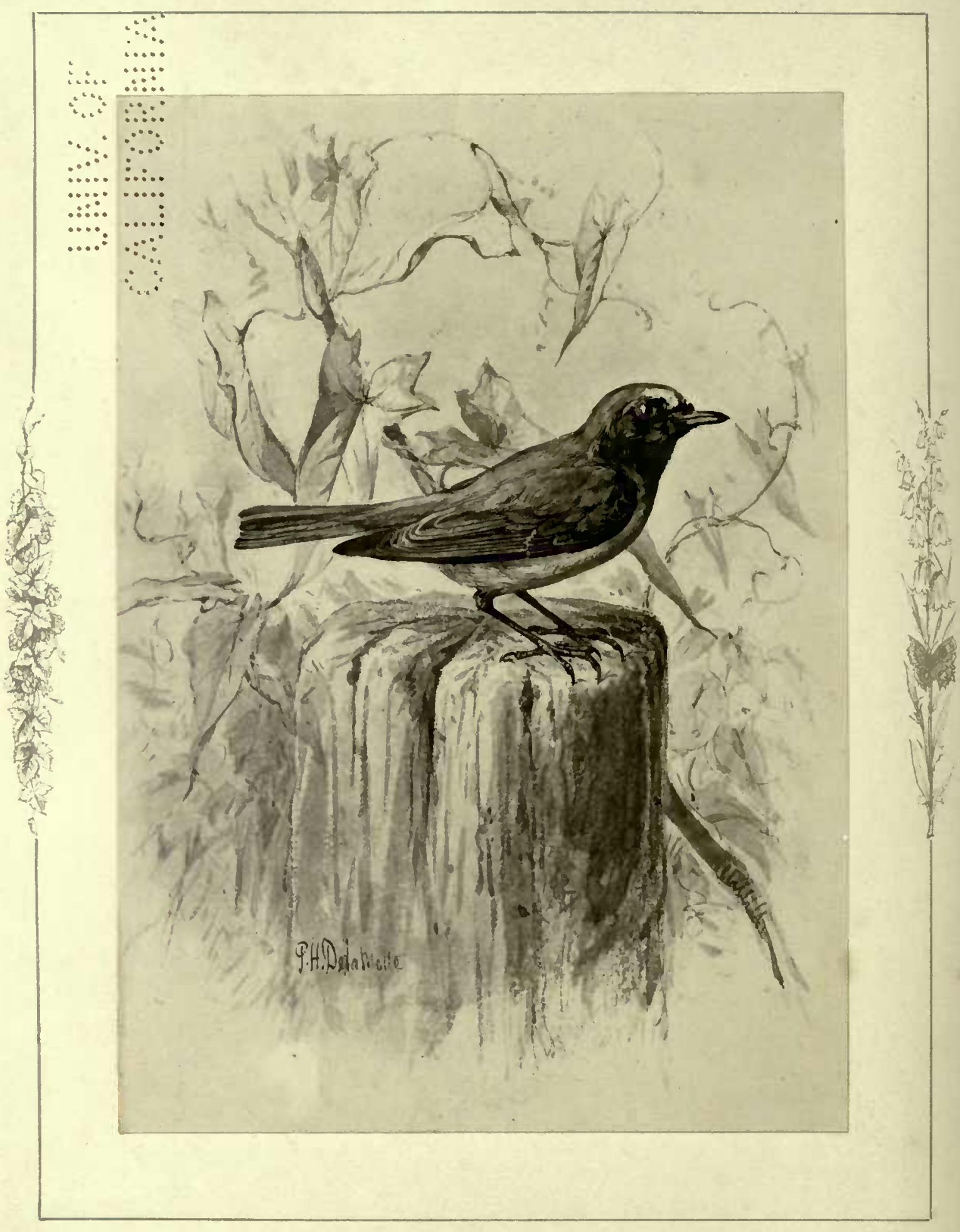

THE REDSTART. 
are its principal Britisly localities; it has been known to breed in Yorkshire and Northumberland. It forms its nest on the sea-coast, where few sticks can be obtained, of seaweed, lined with wool, grass, and hair, but in other localities forms it of sticks, with the same lining. The eggs are commonly larger than those of the rook; it lays from four to five eggs in April.

They are migratory birds, in the autumn they make inland and follow the ploughs.

REDBReAst (Sylvia mbecula), p. 170.-“ This bird," writes Mr. Napier, "forms a firm, compact nest of moss and leaves, which it lines with hair of the horse or cow ; it is rather deep, and is excecdingly comfortable; it is placed in a varicty of situations, as under sea-kale or flower-pots in gardens, or in old walls; it loves to build among the haunts of man, and often selects the most singular situations for this purpose. The eggs of the robin are from four to seven in number; they lave most commonly a white ground, with brown ochre spots, which vary much in size and distribution. Some are almost entirely covered with minute indistinct spots, with a few more clearly defined at the large end. Othors have a zone of large ochre and ash spots at the large ond. A third is of a pale yellowish-white colour, without spots, and a fourth is pure white, and spotless. Robins' eggs may be found which nearly resemble in markings some varieties of those of the blackeap, gardenwarbler, red-backed shrike, greenfinch, nuthatch, and grey wagtail."

Robins aro kept by many people in London; they are free singers in cages, and will live for years. In the winter they come to towns and houses. In the spring they entirely disappear to breed in the wroods. Like the hedgesparrow, the robins go to nest very early in the spring; the robins pair about the middle of February, no matter how bad the weather may be.

There is much truth in the story of birds pairing at Valentine's Day. About this time the following British birds are to be found in pairs : blackbirds, thrushes, hedge-sparrows, common wrens, long-tail titmonse, \&c. In the case of the long-tail titmouse, the old birds and the young ones keep together all the winter, but about the middle of February, the happy family party breaks up, and cach looks ont for its matc.

It is a rule among most canary bird-dealers to "pair up" their birds actually on Valentine's Day.

ReDstarT, p. 173.-The Pedstart (S. phonicura) is a summer visitor to Britain, but is not universally distributed. It breeds in 
liollow trees and holes of walls ; the nest is variously composed of moss, grass, and dry leaves, and is often lined with a little hair. The eggs are much smaller, but are of the same colour, as those of the hedge aecentor. They are more pointed in form than those of that bird, and are from five to eight in number. This kind is very common in the southern parts of England.-G. NAPIER.

The HedGe-SPARRow (Accentor modularius), p. 174.-It fornis its nest of moss, to which wool is frequently added; an outside fortifieation of sticks guards it; the inside is lined with hair, either of the horse or eow. But the nest is sometimes ehiefly, if not entirely, composed of grass. The eggs are always of an unspotted blue green, which varies little in shade; they are from five to six in number. It breeds from Marelı to June. This bird bas a pretty plaintive little song, and is a free singer in a cage. A good bird is worth five shillings.

WRYNECK, p. 175.-This is a migratory bird, arriving here in the middle of April and leaving about the end of August. It breeds in the holes of trees and feeds on banks on ants, and on insects under the bark of trees; they are easily raised from the nest, but "eaught birds" will never feed. The young should be fed on scraped beef and hard boiled egg. It is ealled the euekoo's mate, because it arrives about the same time as the cuckoo. It is also called the "snake bird," because it has a curious habit of twisting its lead right round-over its back like a snake. This habit ean be easily observed when a live wryneek is beld in the hand. The wryneck is an easily eaught bird, and is sure to eome into the net if the ground is turned up and a fresh "scrape" is made under a hedge, when laying for the summer bird tribe or soft-billed birds.

The toes of the wryneek are very peculiar; there are four on each leg, two long toes outside, the short toes are inside. This is a most peculiar formation, well adapted for climbing a tree. They are wonderful runners on the bark, and will deeeive by running round the baek of a tree.

"The wryneck (Yunx torquilla)," writes Mr. Napier, " places its six to ten eggs in the holes of trees. They are usually pure white when blown; but I have several which have a slight tinge of green. Before being blown, they are of a fine salmon colour, owing to the transparent nature of the shell; they have less lustre than the woodpeeker's. The wryneck lays its eggs on ehips of rotten wood, to which it sometimes adds a few feathers and moss. It is widely distributed, and is a summer visitor to this eountry." 
SHowers of CoBweBs, p. 189.-An excellent account of aeronantic spiders has been published in "Researches in Zoology," by John Blackwall (Van Voorst, Paternoster Row, 1873). Mr. Blackwall writes, as regards a shower of cobwebs :-

"A little before noon on the 1st of October, 1826, which was a remarkably calın sunny day, I observed that the fields and hedges in the neighbourhood of Manchester were covered over by the united labours of an immense multitude of spiders, with a profusion of fine, glossy lines, intersecting one another at every angle and forming a confused kind of network. So extremely numerolis were these slender filaments that in walking across a sinall pasture my feet and ankles were thickly coated with them. It was evident, however, notwithstanding their great abundance, that they must have been produced in a very short space of time.

"From contemplating this display of gossamer, my thonglits were naturally directed to the animals which produced it; and the countless myriads in which they swarmed almost created as much surprise as the singular occupation that engrossed then. Apparently actuated by the same impulse, all were intent upon traversing the regions of air; accordingly, after gaining the summit of various objects, as blades of grass, stubble, rails, gates, \&c., by. the slow and laborious process of climbing, they raised themselves still higher by straightening their limbs; and elevating the abdomen, by bringing it from the usual horizontal position into one almost perpendicular, they emitted from their spinning apparatus a small quantity of the glutinous secretion with whicl they fabricate their silken tissues. This viscid substance being drawn out by the ascending current of rarefied air into fine lines several feet in length, was carried upwards, until the spiders, feeling themselves acted upon with sulficient force in that direction, quitted their hold of the objects on which they stood and commenced their journey by inounting aloft."

Mr. Blackwall's experiments on these spiders are very interesting.

Silk of SPIDer.-Mr. Groom Napier writes:-"I gathered about 200 cocoons of the garden spider; these being wound with a common silk reel, were twisted into thread of different thicknesses, which I again twisted into cord, some as fine as purse silk, others as thick as whipcord, but had only a few inclies of each length. This being tested against the thread of the coinmon silkworm of similar weight, proved to be twice as strong. The great objection to this silk for ornamental purposes 
is its dull colour. I tried it with several dyes both aqueous and alcoholic; the latter succeeded best, but not quite so well as an oily stain made by soaking alkanct root in linseed oil, the oily matter of which was removed by washing with soapsuds. Some spider silk, it would appear, has naturally a beautiful colonr, such as that which Dr. Wilder describes as discovered by him at Folly Island in Charleston harbour in 1863. He wound, in an hour and a quarter, 150 yards of yellow silk from the body of one spider. One of his brother officers wound 3,484 yards, or nearly two miles of silk from thirty spiders. This thread was capable of sustaining from 54 to 107 grains. He describes the silk as yellow and white with a Instre as brilliant as gold or silver. I once obtained a cocoon of an English spider which appeared to have been spun with gold thread. Dr. Wilder found great difficulties in rearing the spiders, from their tendency to prey on each other, which, I fear, will reuder it next to impossible to turn this beautiful spider-silk to practical account."

Honses, p. 191.-I am certain that a great niany racehorses are made very savage by being shut up in stalls away from other horses; a horse is by nature a gregarious animal, and it is pain and misery to him to be shut up alone. Horses have very quick hearing, and at night timid horses are often kept awake by rats moving about. Rats, therefore, should always be exterminated in stables. Goats are often kept in stables; as I am told that goats will face fire. Should the stable take fire, the goats will give the horses the lead out of it, whereas if there were no goat the horses would neither walk nor be led out. It is said that to a horse's eye everything is magnified, and this is the reason why man has such power over him; to a horse a man possibly appears to be of a gigantic size. The molar teeth of horses fastened together with cement form very ornamental mosaic pavement for summer-houses or eltrances to liall-doors. They may be also cut and polished to make ornamental tables for the drawing-room.

Nothing is so difficult to stuff well as a horse's head. There is an old man who supplies gentles to the Zoological Gardens, Regent's Park : the attendants call him the "Gentle-Man." The head of a black horse was once sent to this man to be stuffed, and he confessed to Mr. Bartlett that he had made such a hideous object of it, that "when he went out of a morning he was obliged to cover it over, lest when he came home at night he should be frightened at it."

People who wish to have relics kept of favourite horses should have their ears preserved; they make nice holders for spills; the hoofs also make good inkstands; and the tails mounted on a stick are an exeellent thing to kill flics. 
LoNG TAILS FOR Horses.-I once measured the tail of a hearse horse, which I observed when attending a funeral. It was no less than six feet in length. I presume the fashion of driving long-tailed horses has been handed down from the olden times, perhaps from the days of Queen Anne, when all the swell carriage-horses wore long tails. There is a legend that people at Oxford who let out grazing fields for horses in the long vacation charge more for a long-tailed lorse thran for a short-tailed one, because the long-tailed ones eat more than the others, which are obliged to waste much time in driving off the flies, while the long-tailed horses keep off the flies with their tails and eat continuously. I cannot help expressing a wish that some of our aristocratic carriage-owner's would set the example of nct eontinuing to disfigure their horses by cutting their tails. In addition to a moderately loug tail being a great ornament to a horse, it is also of great use to the animal, by enabling him to brush off flies, especially if at any time lie should happen to be turned out into a field, or if he is in a stable in the country, where flies are more numerous and troublesome than in London. I believe that the custom of eutting short the tails of loorses has been adopted nerely because, if they were longer, the grooms would have a little more trouble in combing and washing them. I do not know of any good reason why the tails of saddle-liorses sliould not be also allowed to grow longer than they usually are in the present day.

Intelifigence of Horses Dependent on the Size of the BRAIN.-A man that trains canary birds and exbibits a performing hare in the streets, tells me that he always selected a hare for a pupil which liad a large head; all hares were not equally capable of instruction. When in the 2nd Life Guards, I used often to watch the officers' liorses and the troopers, to see if the lorses which had broad forelieads knew their drill better than the small frorted liorses, and I fancy that the larger brained liorses were the more clever of the two. At a dinner party at Aldermaston Park, I met a gentleman who hảs many luunters, and I asked hin kindly to measure his horses' foreheads, taking the upper measurement between the temporal fossa, and the lower between the orbits of the eye; the following is his answer. "I liave measured four of my liorses' heads in the places you wished:-

Temporal fosse. Orbits of eyt.

1. Beauty (an intelligent mart) ....measures $5 \frac{1}{2}$ in........ $8 \frac{1}{2}$ in.

2. Tocket (a fearful puller) $\ldots \ldots \ldots \ldots \ldots \ldots . \ldots . \ldots . . .6$

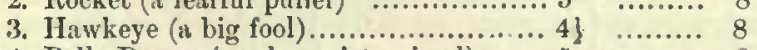

4. Bella Donna (a calm quiet aniual) ...... $58 . \ldots . . .6$

VOI. II. 
I have measured each horse twice, and the most iutelligent animal I ever possessed measured most."

Gipsies, 1. 193.-The gipsies round London are called Romanies. Their great settling places are Epping and Hainhault Forestis. This year, 1875 , notices have been put up on the trees in Epping Forest that the Romanies are not allowed to encamp on the forest any more. There is no rabbit or hare that is too lieavy for a gipsy's dog. Round the King's Oak, High Beach, Epping Forest, pleasure vans assemble in large numbers from London. The Romanies get a great deal of money in the summer by letting donkeys and ponies for children and young people to ride. At the begimning of winter many Romanies may be seen on Fridays in the Islington Cattle-market selling their "mokes" and ponies to costermongers. Mokes fetch from one guinea to five pounds. Little donkey foals can be bought for five shillings each. About May, the Romanies give very high prices for good donkeys. The Maharajah Dhulep Sing told me that the gipsies' language was very like his own native Sikh tongue; he could understand many gipsy words.

While collecting notes for this volume I was fortunate enough to obtain a copy of "The Gipsies' Advocate; or, Observations on the Origin, Character, Manners, and Habits of the English Gipsies. By James Crabb, 1832."

The information given by Mr. Crabb exactly coincides with what the Maharajah told me. There is the strongest evidence that gipsies are of Hindoo origin, and there is great resemblance in their language to Hindostani, as will be seen by the following table :-

$\begin{array}{lll}\text { Fnglish. } & \text { Gipsy. } & \text { Hindostani. } \\ \text { Water } & \text { Pang } & \text { Pang. } \\ \text { Prince } & \text { Rajah } & \text { Raja } \\ \text { Fish } & \text { Mutchee } & \text { Mutchee } \\ \text { Father } & \text { Dad } & \text { Dada }\end{array}$

It is said that twelve out of thirty words of the gipsies' language are either pure Hindostani or nearly related to it.

The gipsies are said to have been driven out of India by Timur Beg in the years 1408-9, when making proselytes to the Mohammedan religion.

Immunity From Bee Stings, p. 197.-My brother-in-law, the Iiev. H. Gordon, writes me:-

"IDIOT BOY'S FONDNESS FOR BEES.-I have in my parish at the present moment an idiot, aged 17 last April, of whom I had the following account from his sister, Mrs. I'rior, at East Harting, 
with whom he lives. 'Sir, he worships his bees. After brakfast he'll set and watch them, and I be forced to take his dinner ont to him. He doesn't like his bees to die-can't bear to hear the sound of death; but he likes anybody else's to die. When you were stung, he laughed heartily, and said "it wasn't no use for anybody to keep them spiteful bees; he didn't do that himself." He rings anybody's bees with a pot-lid and key, but won't hive them himself. He coaxes 'em out, and calls'em, "Cone along, little fellows, come along, little fellows."

"His father, Inke Todman, was a very exact and religions man; one brother who was in the Life Guards died. 'Father went and waked the hives;' he said:-

$$
\begin{aligned}
& \text { "Awake, little bees, awake, } \\
& \text { Yonr old master's dear, and a new one you must take." }
\end{aligned}
$$

"You innst wake (confer. Irish wake) the bees before the sun rises next morning after the death. If they are not told of the death of their master the bees pine away and die. Haury Prior's first wife died and her bees with her; Harry never told them, and he never had any since. He never waked them; and since that he went shares with Master Blunden, at Rogate, in a hive of bees, and he died, and the bees were never waked, and they died.'

"People certainly seem to get inured to the bee-poison after a time, as sailors, from practice, do not feel musquitos, but per contra suffer much from the fleas on land. Nerve will enable people to do almost anything with bees, but if it flags for a moment you will receive, as I know to my cost fourteen years ago, many stings at once. Is it possible that some are so thickskinned that the sting cannot penetrate; or that the virtue of being sting-proof is like immunity from some fever poisons, a peculiarity handed down from ancestors.

"It is certain that White's idiot-boy could have felt nothing of the sting of a bee.

"I have little doubu that the idiot in question had a skin too thick for the bees' stings, and that the bees knew it. Bees know in a moment when you begin to fear them-yon communicate your panic to them, and they stiletto you to their own death, disembowelling themselves.

"I have for nearly twenty years kept bees, and beyond mere rule of thumb handling of them am satisfied that I know next to nothing about them, but can only echo, ore rotundissimo,

$$
\text { "—_ npibus quanta experientia pareis." }
$$

A magnificent work has lately been published in French-(J. 
Rothschild, Editeur, 13, Rue des Saints Pères, Paris) - on the Anatomy and Physiology of Bees, by a Russian engineer, Mr. Michael Girdwoyn. The drawings are marvellously beantiful. Every one interested in bees should have a copy of this work, which costs thirteen or fifteen francs.

Effects of Trees on Rainfall, p. 201.-Mr. Menzies, Deputy Surveyor of Windsor Forest, writes me thus :-

"Mr. White has entered upon one of the most abstruse questions of forest economy, to which much attention has been given since his time. The only time when trees do truly perspire is in the sunmer, when some kinds, such as notably the oak and beech, distil a sort of dew from their leaves. It is quite true also that they prevent evaporation from the surface of the ground, and so have a tendency to prolong the supply of water that any district may yield; but on the other hand they themselves are great drinkers of the water in the subsoil, and so again they diminish the store. Whether these two tendencies counterbalauce one another, or whether trees favour the storage of water most, has by no means been settled. Practically no one would think of surrounding a reservoir of pure drinking-water with trees; because the falling foliage injures the water, and the effects of trees, in condensing water which is present in the air, are infinitesimal. Any account given by travellers of the diminishing of streams in any country in consequence of the denuding of the district of trees must be received with extreme caution-just as we know that we must be guarded in receiving from people of this country stories of the extremely cold winters and hot summers which used to prevail in their youth. The statistics of rainfall have only been collected in England within the last ten years with anything like scientific accuracy, and in other parts of the world the science is quite unknown. Hence we have no real data to go upon, and without a series of actual gaugings of the streams extending over a number of years, a truly valuable opinion cannot be formed. Since Mr. White's time many thousands of acres in England have been cleared, and inany thousands have been planted, but no data exist to form any reliable opinion as to the effect, if any, upon the rivers; and such data would become vastly complicated, as it would be necessary at the same time to consider the effect of the agricultural drainage and the formation of canals, \&c., that have been done since his time. My own opinion is that in England the trees bave had no effect one way or the other. I have read many accounts of the effect, in other countries, of large forests in condensing the moisture on the hills, and the balance of evidence 
is in favour of their doing so; but at the same time there was little to support the statement beyond general opinion, which is subject so much to conjecture. Although, therefore, Mr. White has given a very charming account of a popular idea, accurate scientific investigation since his time has not confirmed his views, and people in England who consider the question of the storage of water attach no importance whatever to the presence of trees in promoting that object on any scale in this country. With regard to the formation of dew-ponds on the chalk hills, you must refer to the Rev. J. Clutterbuck, Long Wittenham, Abingdon, Conservator of the Thames, who has written and knows more upon that subject than any one else in this country. "W. M."

Lord Northwick, who for many years past has kept meteorological records at his seat near Tenbury, informs me that he has ascertained by experiment that a rain guage of a given size, without vegetation, catches three times as much water as a similar guage planted with vegetation. The vegetation absorbs the water. His Lordship argues, from the above observation, that less drainage is required in pasture lands than where there is no vegetation.

Viper Swallowing ITS Young, p. 205.-It is still believed by many that a female viper will swallow her young when they are in peril. In nearly all the cases that liave come under my examination, the event always happened a long time ago. The witness generally begins his statement thus: "When I was a little boy," "Many years ago," "My grandmotlier told me," \&c. \&c. If vipers swallowed their young "many years ago," why should they not do so in our time? A correspondence on this subject takes place in Land and Wuter almost every year. I have made many anatomical preparations to show that the young vipers found inside the mother have never been born. I still continne my public offer of a reward of $£ 1$ for a specimen of a viper which has been seen to swallow its young, the young being actually in the cesophayns, or in the stomach proper, when it is opened by me in the presence of witnesses. The result of the correspondence out the viper swallowing its young has been thus put into verse by my friend, Henry Lee:-

Tile Viper (not) Swallowing its Youna. TUxi-Lord Lovel.

Frank Buckland he stood at his casting slate, Smoking his usual weed,

When there came a smart ring at the front-door bell, Which John ran to answer with speed, speed, speed, Which John ran to answer with speed. 
"Well ! what is it now ?" Frank Buckland he said,

"Now, what's in that parcel?" said he ;

Suid John, "Please sir, it stinks, so it's something dead,

And it comes from the country, I see, see, see,

And it comes from the country, I see !'

"It's a riper, no doubt," Frank Buckland he said,

"And they'll want to persuade me," said he,

"That it's swallowed its young, one, two, three or four,

To confirm their inistaken fancee, cee, cee,

To confirm their mistaken fancee."

He was just going to cut up the snake as it lay,

And to open its stomach to see,

When a sensible thought came into his head,

He would send for his friends Lord and Lee, Lee, Lee,

He would send for his friends Lord and Leo.

So he gave it a posthumous milk-white feed, For some plaster he pour-ed down,

At length came another brisk ring at the bell,

And $\mathrm{H}$. Lee the stairs ran down, down, down, And $\mathrm{H}$. Lee the stairs ran down.

"Oh! what is the matter?" H. Lee he said,

"Oh! what is the matter?" said he,

" Here's a viper that's dead," Frank Buckland he said,

"And she's swallowed her young, they fancee, cee, cee, And she's swallowed her young, they fancee."

Then he ordered the throat to be opened wide,

And the skin to be turn-ed down :

And then he cut into the clay-cold lump

of plaster that he'd poured down, down, down, Of plaster that he'd poured down.

Soon he flung down his knife by the side of the corpse,

With a right merry laugh and a giggle,

"It's a strange thing," said he, "folks will swear that they see

Young snakes down their mothers' throats wriggle, iggle, iggle,

Young snakes down their mothers' throats wriggle.

"We've disproved it before, this disproves it to-day,

But they'll fancy the saune thing to-morrow,

Every snake that they send contrudicts their belief,

Yet they're obstinate still, to my sorrow, orrow, orrow,

Yet they're obstinate still to my sorrow.

"Here's a young one, it's true, but it's never been born, It has ne'er been in stomach or throat;

In fact, as you see, it's just where it should be,

Uutside the abdominal coat, coat, coat,

Outside the abdominal coat.

"The young vipers grow here till it's time that they stop, And then they go lower, not higher;

Till they're born they're coiled up in a true lover's knot

For naturalists true to admire, ire, ire,

For naturalists true to admire." 


\section{Morat.}

Good gentlemen all, both great folks and small, This hint accept kindly from me,

We want evidence clear ! don't believe all you hear, And not more than half that you see, see, see And not more than half that you see.

\section{HeNry LEe.}

Holland, the keeper of the snakes, tells me that vipers under lis charge at the Zoological Gardens often have young in their glass dens. The vipers that liave had young are the Russell viper, black water viper, and the common viper. In no instances have any of these vipers attempted to swallow their young alive. Snakes frequently swallow each other when they have had loold of the same frog, and the swallowee has to be shaken out of the gullet of the swallower. Mr. Bartlett once made a boa-constrictor take a full meal in a very ingenions way. Boas, as is well known, will never seize an animal which is reacl. The boa in question lad not fed for many weeks. At last he seized a live rabbit, killed it by crushing, and swallowed it. Just as the rabbit was disappearing down the snake's mouth, Mr. Bartlett tied another dead rabbit to the legs of the one being swallowed, then another on to that. The snake must have thought that he had got loold of a tremendous long rabbit.

In the summer of 1875 , my friend Mr. Burr forwarded me a small viper alive, with the mouse he disgorged when captured. His under-keeper caught him, and observing that he was very large in the middle, thought he had some ailment,

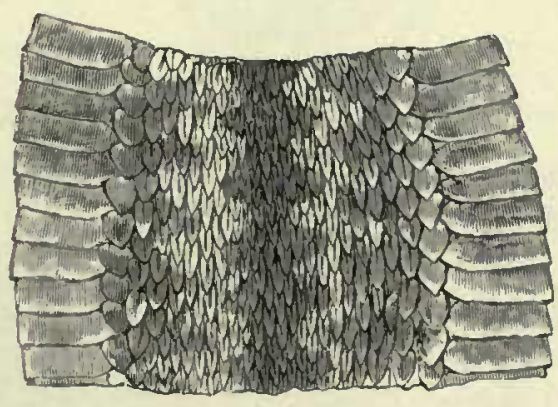

SKIN UF VIYER.

but on handling him lie brought up the mouse, which is very much larger in girth than he is. The viper measures about ten inches, and is about the size of a common Severn lamprey. The mouse was a field-mouse, and about the size of a three- 
parts-grown commou monse. It seems lardly possible that the inouse could ever have gone down.

The engraving on the preceding page represents the skin of a viper. Directly the animal is killed, the skin or a portion of it should be stretched on a flat glass. The beautiful pattern of the scales in a skin so treated is much to be admired. Oil-cloth manufacturers should copy it.

Poison Fangs of Viper, p. 205. - Gilbert White does not seem to have been much of an anatomist. He probably therefore never dissected the poison apparatus of the viper or other venomous snakes. Mr. Delamotte has therefore kindly at my request given us drawings of dissections I have myself made of the poison apparatus of the rattlesnake. It is the same, on a larger scale, as the viper. Fig. 1 represents the palate of the

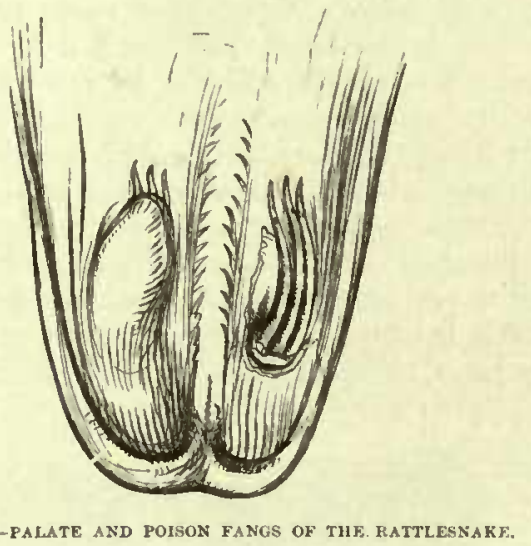

snake; the lower jaw is supposed to be removed altogether. The poison fangs, when the snake is not imitated, lie back parallel to the roof of the mouth, so that they will not at all interfere when the snake is swallowing its food. On the left hand of the drawing will be seen the projecting tips of the fangs. The fangs lie in, and are protected by a fold of the gum, which serves two purposes ; first of all, it prevents the poison being thrown broadcast when the snake lites, and secondly, it protects the fangs from injury. On the right hand side are seen the fangs from which the bag has been dissected off with the scissors. In this case there are three poison fangs all abont the same size.

Fig. 2 shows a further dissection of the fangs as contained in this pouch or bag. One side of the bag being cut away, it will 
be seen that it envelops nore than one poison fang. There are generally five or six in a row, one after the other. On each side of the snake's mouth one fang is fixed firmly on to the bone which works it; the others are all more or less loose, and by some wonderful process, not yet known to us men, when the front fixed tooth gets broken off or is shed, another inmediately comes up as its successor from behind. It will be olserved that there is a small bristle ruming through the largest of the fangs, the tooth in fact is perforated by a beautiful dnct or pipe.

Professor Owen thus writes in his valuable work "Odontography; or, A Treatise on the Comparative Anatomy of the Teeth":- "A true idea of the structure of a poison-fang will be found by supposing the erown of a simple tootli, as that of a Boa, to be pressed flat and its edges to be then bent towards each other, and soldered together so as to form a hollow cylinder open at both ends. The flattening of the fang and its inflection around the poison-dnct commences immediately above the base, and the suture of the inflected margins runs along the antcrior and convex side of the recurved fang.

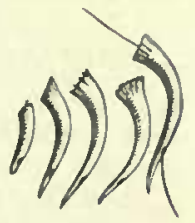

Fig. 2. - poison FANOS D1SSECTEI 'The poison canal is then in front of the pulp cavity." When a poisonous suake strikes its enemy, it can hardly be said to bite. It rather gives a sharp instantaneous stab, knowing instinctively that the poison once injected into the wound will do its work. To enable them to strike so quickly, all poisonous snakes have, about the foremost few inches of their body, very great powers of darting.

When experimenting on the poison of living vipers, I found that, when a viper is held tight by the neck, he will erect his two working fangs and move them backward and forward with more or less rapidity, exactly as a man moves his arms when about to fight another. When the viper was thoroughly enraged and had got his steam up, I placed quickly a microscope slide under the fungs. In one moment the fangs came sharply down upon the glass and two drops of poison were emitted, one from each-fang. I instantly put these under the microscope, and witnessed a most extraordinary appearance, namely, a crystallization of the poison. I lave not space to describe this in detailsuffice it to say that the poison, when nearly evaporated very much resembled the crystals of hoar frost on window panes on frosty mornings. This, I believe, has not been observed for about a hundred years; by great good luck I discovered that Dr. Mead both saw and described it. This learned doctor's account voL. II. 
can be found in his book, "A Mechanical Account of P'oisons, by Richard Mead, M.D., physician to His Majesty, 1748." A most magnificent work has lately been published by my friend, Dr. Fayrer, now in India with the Prince of Wales: it is "The Thanatophidia of India : being a Description of the Venomons Snakes of the Indian Peninsula, with an Account of the Influence of their Poison on Iife, and a Series of Experiments" (J. and A. (hurchill, New Burlington Street). The coloured drawings of the snakes by native artists are most beautiful and life-like.

I regret that I have not space to describe here the Coronella Tevis, a suake exceedingly like a viper, but not poisonous. It is found in the New Forest, but not at all commonly. It feeds upon lizards. I have had several in my possession.

How to Catch a Vipek-Mr. Davy thus describes the modus operandi:-" I generally catches him with a forked stick; I pins hin to the ground, then I squeezes his month sideways, and scrapes or cuts his fangs out with a knife. I then scrapes out his poison bag, and rinses out his mouth in the nearest water; I then puts him in a bag. He will never open his inonth again to bite you any more. I used to find most of these gentlemen round by chalk-pits near Guildford. So long as you gets these vipers short up by neck they cannot harm you, though they start and swish their tails about like mad; they are very dull biters on cold clays, but they fly through the grass of a hot day. I puts adders and common snakes in a bag altogether. There is no sale for them in London now-only occasionally a gentleman or two might want them. I know an artist who used to keep four or five in a ferncase to feed with half-grown mice. If they were not doctored well they would dart at the glass. I was once bitten by a viper : I was a beating for larvæ, and did not see my gentleman, who was lying on a chalk bank which I was climbing up from below. I never saw him, so he catches the forefinger of my left hand. The bite was a very sharp prick, like the bite of a mouse. I sucked it for half an hour; I felt pain next morning. It was sore and painful for four or five days."

Mr. Davy's men, as well as himself, have frequently found young adders in lanes in chalky districts in various parts of the country; he has never seen or heard of any one who has seen the viper swallow its young. He says, "I have had men out daily for years in all parts of the country, and none of my practical bird-catchers believe in it. The story of vipers swallowing their young is all old Mother Hubbard."

My friend, Major Rogers, who has done so much to get tigers destroyed in India, has shown me how to make a noose for 
handling poisonous snakes or any wild animal; one end of a piece of cord is ticl on to the end of a stiek, the other end is made to run loose through a turn in the cord; the noose is then slipped over the head of the snake, and thus he ean he easily transferred from a box to a eage or other reeeptaele. Mr. Bartlett informs me that when a poisonous snake arrives at the Zoological Gardens they transfer him to his new residence by unfastening the lid of the box and leaving it on loose; they then put the box into the eage and with a long crooked iron rod push off the licl and hook out the snake; when they wish to lemove the smake from the eage into the box, an apparatus like Major liogers's or even a common twitch, like that sometinies used by farriers to hold a horse by the nose, is used.

Ratrle of RatTleswake.-There is a no more deadly snake than the rattlesnake. In this horribly poisonous reptile we find a most extraordinary apparatus to facilitate its getting up to its prey. This consists of literally a rattle on the end of its tail.

Mr. Thomas Hughes, M.P., in January 1871, was kind enough to give une a very fine speeimen. of the rattle of a rattlesnake. It is about two inches and a half long, and is composed of nine joints. This piece of mechanism is one of the most wonderful in the animal world. It is composed of a horny material, very thin, and is almost as transparent as the sheets of gelatine in which bon-bons are wrapped. It is (lifficult to explain its ultimate structure in words. The rattle before me is formed of niue complete bcxes, fitted one into the other in a more ingenious way than any puzzle made by limman hands, even those of the Chinese; these loxes fit one into the other so that it is impossible to get them apart without breaking them. See figtire.

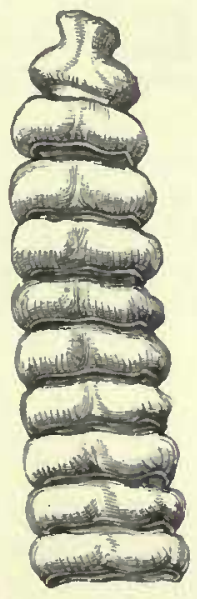

The rattle is rather more than half an incl across. The snaké does not earry it with its broad side to the groumi, but with one cdge up and the other down; when shaken with the lumman hand the noise it makes is very like the noise from a child's rattle; but when the snake plays upon his own instrument its sound is quick and sharp like shot when chropped on a tin plate. I an told that when the snake rattles in the open air the sound appears to come from anywhere but the spot where the snake lies. There can be no doubt that 
this curious musical instrument (for so it may be called) is given to the snake in order to enable him to get elose to his prey. Imagine a blazing hot day on the desolate prairie, no noise, everything is sileuce itself. We all know what curious noises are heard on oecasions like this. The whirr-whirr of a rattlesnake's rattle would, under these eircumstances, attract the notice of a bird or small mammal, who eould easily escape from his enemy by flight if he knew where his enemy was. He remains perfectly still, however, to listen to the nnwonted noise, and gives the snake time to glide noiselessly up to him and strike him with his deadly fangs. Some time since, an American uentleman happened to be talking with me in my museum, when I suddenly played up a rattlesnake's tail. My friend, a traveller, who knew the sound well, immediately jumped suddenly aside in great alarm, thinking that I might liave a rattlesnalke loose in the room. I hear that pigs will eat rattlesnakes, and that the poison does not seem to affect them. I think that this may he possible if the venom strikes into the fatty portion of the pig's face.

I know that rattlesnakes cannot play up their rattles in wet weather. The horn of the rattle becomes more or less saturated with water, and no sound can then be produeed from it. By placing a rattle in a glass of water, and letting it soak a while, I find this is the case. When it is dried the sound (anl again be produced.

Wourali Porson.-Gilbert White probably never heard of the existence of Wourali poison; it is one of the most fearful poisons

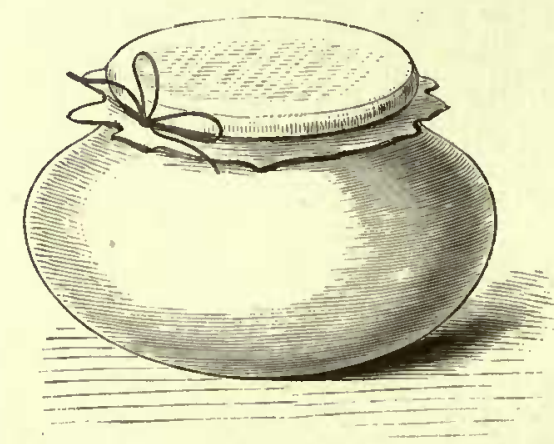

POT OF WOURALI POISON.

known. It is made by the Indians in Demerara, and when made is kept in little gourds, as represented in the engraving. I have two 
very beautiful specimens of this wourali; it looks like hard pitel or resin. In his "Wanderings," Mr. Waterton gives an interesting account of its manufacture. He says that its principal ingredient is a vine called wourali. The Indian takes the vine and adds to it a root of a very bitter taste, and two kinds of bullous plants, which contain a green and glutinous juice. 'To these are added two kinds of ants, one very large and black, and very venomous; the other is a little red ant which stings like a nettle; he then adds the strongest Indian pepper and the pounder fangs of snakes, called Labarri and Counaconchi. It is then prepared over a fire. Animals killed by wourali are good to eat.

The Indians will not allow any wonen to be present when they make the poison, which is conducted with great ceremony and mystery combined. Wonrali is said to be a vegetable poison $-a$ bircl inoculated with a small dose of it will die in less than three minutes. My own opinion is that snake poison forms a considerable part in its ingredients.

This engraving shows the dart used with the womrali poison Fach dart is about ten inches long and tipped with the poison.

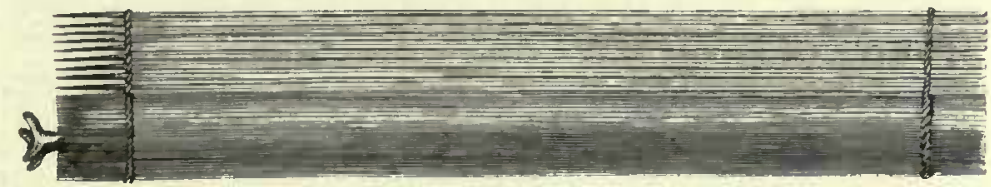

DARTS TIPPED WITH WOURALI POISON.

The darts are beautifully fastened togetler in such a ntanner that they can be rolled round a centre support. To the top of the quiver in which the arrows are kept is tied a row of sharp teeth of a fisl,; with these the Indian cuts lialf through the dart just above the poisoned tip. When the animal is struck the dart breaks off short at the point and the little poison-covered end remains in the wound, spreading its lethal intluences.

Eartir-worms, p. 210, ann Sxails, p. 250.-My father made several observations on earth-worms. I possess his manuscript notes on this point, which are to this effect: "The digestion of animals is a geological power of greater extent than might at first sight be imagined. In the operations of earthworms we find an example.

"It is a bad thing to plongh up ancient pastures, as a number of ycars are required to reform the mould, the result of centuries of 
digestion by these humble and hitherto unappreciated fellowlabourers with farmers to ameliorate the condition of the earth's surface, and to adapt it to the production of grass, food for the higher animals. Thus the whole of the earth which forms a rind of turf has again and again passed through the entrails of the successive generations of earth-worms. A check upon the too great increase of earth-worms is afforded by their being the food of birds and moles. See also Literary Gazette, Nov. 25, 1857."

The earth-worm is admirably adapted by its structure for tunnelling in the earth, and its wonderful borings are often laid bare in the railway and other cuttings. When we consider the great pressure of earth, besides its solidity, through which these worms have to bore, it seems surprising that their delicate organisms should not be crusbed. The body is made of a number of small rings, which are armed with short, stiff, harsh bristles, hy means of which they pull themselves along. As the seamouse has brilliant hairs, and the Cape mole has lustrous fur, so the earth-worm's cuticle has a shining, iridescent lustre, the reason of which I am not in a position to explain. The nervous and vascular system of the earth-worm is very complicated. It lays eggs, for which the reader should look in decayed dung lieaps. The mouth consists of two small lips, the superior of which resembles, in some degree, that of the Tipita. In the loyal College of Surgeons, there is an admirable preparation (No. 470) of the anatomy of the earth-worm.

"The œsophagus, a wide membranous canal, is continued straight dowu for half an inch, and ends in a delicate bag, or reservoir; to this succeeds a museular stomach, or gizzard, disposed in the form of a ring. The intestine is constrieted at eacli segment of the animal by a series of ligaments or partitions comnecting it to the parietes of the body, and swells out in the intermediate spaces when distended by the particles of earth."

Mr. Davy informs me that eommon snails are very palatable food for hungry peopla. Cut off the point of the shell and pick them out with a pin like a winkle; put them in salt and water for an hour. In winter they are wapital eating. They should be boiled in milk, but are very good when eaten raw. Snails are used by hundredweights in London and the provinces for feeding thrushes and blackbirds; the men eollect them in market-gardens and hedgerows. They are sold wholesale at $2 \frac{1}{2} d$. to $3 d$. per quart; there are about five dozen in a quart. Birds won't eat water-snails; they are too sloppy; there is no body in them. No small bird eats the black and 
yellow naked slugs; the slime sticks to their beaks and feathers ; fowls and ducks will eat the naked slugs.

Snails are getting very scarce round London; the collectors have to go long distances in search of them, sometimes as far as Gravesend, and Southend, harbours for them being nearly cleaned out round London. The men generally go for them in winter time, when they are collected in great clusters under old rnins, in hollows of trees, \&c. The eggs are little white things, and they are deposited in cracks in the ground; eggs and little snails are found in the same crevice. Snails' eggs are found when digging for ehrysalis. Snails lay eggs in the rrildle of August; they lay them often in cages when fresh brought in for market. Mr. Davy has often had inany bushels of snails at a time; an ordinary shop would very soon sell a bushel of snails. He used to put snails away in a dry cellar. By so doing they will keep good for twelve months.

He once found some snails that must have been in his cellar two years at least. They never had any moisture, nor yet any vegetable matter; they were "cased up" the same as in winter, but the animals were alive inside. As soon as snails are shut up in any dry place they begin to "case" themselves; they never crawl any more unless they get wet upon them.

They begin to "case" when winter comes on. They creep, half a gallon together, into old pollard trees, and deep into dry banks. If two or three days' hard frost comes, and they have not properly protected themselves, they die in thousands. They get rings on the month of the shell every year; some must be very old, seven or eight years at least. They sometimes adhere together, and it is a difficulty to separate them. Snails' eggs are much sought after by thrushes and blackbirds; they are semiopaque, quite round, and half the size of a sweet pea or tare.

I have frequently bought escargots, or the French edible snail, already cooked for enting, at M. Dumas, French provision merchant, 55, Princes Street, Leicester Square; they cost one shilling per dozen.

These snails are said to have been introduced into England by the Romans. They are generally to be found in the neighbourhood of ancient Roman encampments.

The Bulrush, or Vegetable Caterpillar of New Zealand. -I now venture to give- apropos to the subject now before usa drawing of a most remarkable specimen sent to my father about the year 1844 by the Rev. Heury Hobart, from the parsonage, Paramatta, New Soutl Wales. In 1873 I received other specimens from Lieut. John Hayes, R.N., H.M.S. Black Prince, 
with the following admirable description by the Rev. R. Taylor, Waimate, New Zealand :-

"The Aweto is only found at the root of one particular tree, the nata (Metronderos robusta). The root of the plant, which in every instance exactly fills the body of the caterpillar, attains in the finest specimens a length of three inches and a half, and the stem, which germinates from this metamorphosed body of the caterpillar, is from six to ten inches high. Its apex when in a

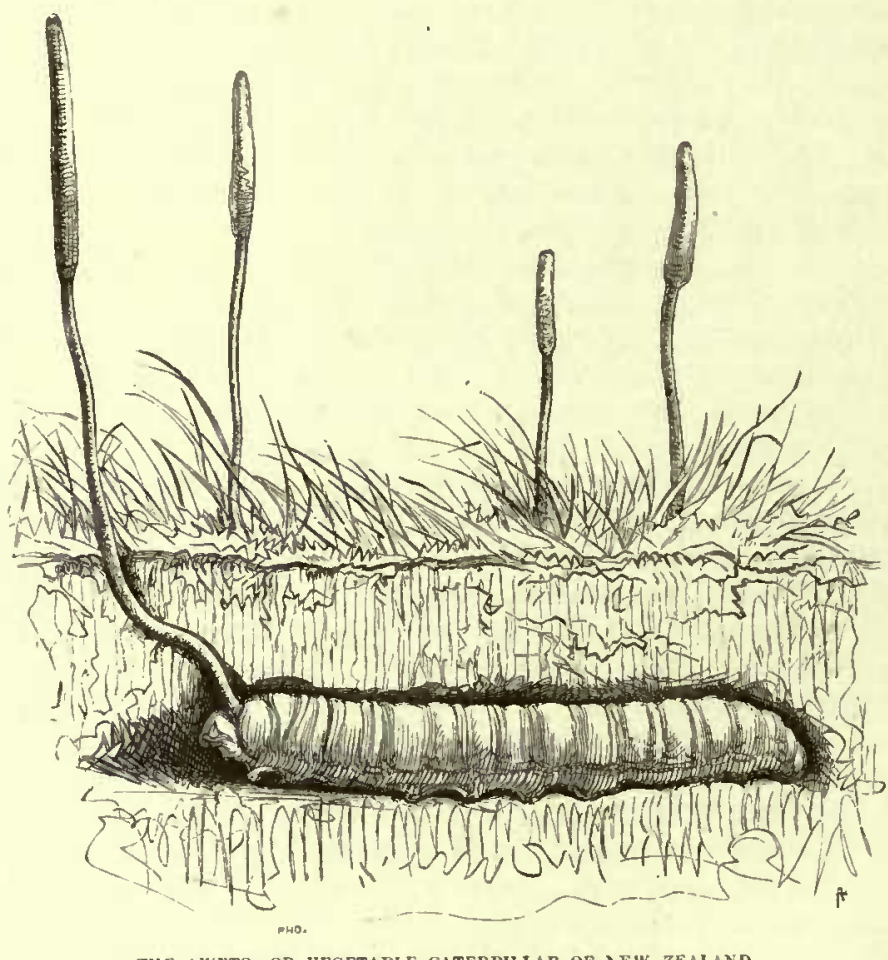

state of fructification, resembles the club-headed bulrush in miniature, and when exanined with a powerful glass, presents the appearance of an ovary. There are no leaves-a solitary stem comprises the entire plant, but if any accident break it off a second stem rises from the same spot. The body is not only always found buried, but the greater portion of the stalk as well, the seed-vessel alone being above ground. When the plant has attained its maturity it soon dies away. 
"These curious plants are far from being uncommon. I have examined at least a hundred. The natives eat them when fresh, and likewise use them, when burnt, as colouring matter for their tattooing, rubbing the powder into the wounds, in which state it has a strong animal smell. When newly dug up the substance of the caterpillar is soft, and when divided longitudinally, the intestinal canal is distinctly seen. Most specimens possess the legs entire, with the horny part of the head, the mandibles and claws. The vecretating process invariably proceeds from the nape of the neck, from which it may be inferred that the insect, in crawling to the place where it inhumes itself prior to its metamorphosis, whilst burrowing in the light vegetable soil, gets some of the minute seeds of this fungus between the scales of its neck, from which in its sickening state it is unable to free itself, and which consequently, being nourished by the warmth and moisture of the insect's body, then lying in a motionless state, vegetate, and not only impecle the process of change in the chrysalis, but likewise oceasion the death of the insect. That the vegetating process thus commences during the lifetime of the insect, appears certain from the fact of the eaterpillar when converted into a plant, always preserving its perfect form; in no one instance has decomposition appeared to have commenced, or the skin to liave contracted or expanded beyond its natural size. A plant of a similar kind has been discovered growing in abundance on the banks of the Murrumbidgee, New South Wales, in a rich black alluvial soil.

"It is a curious instance of a retrograde step in nature-an insect, instead of rising to the higher order of the butterfly, and soaring to the skies, sinks into a plant, and remains attached to the soil in which it has buried itself." The name of the insect is Hipialus vireseens; the name of the parasitic fungus is Spharria Robertsiz.

ILePErs, p. 213.-Having asked my friend Professor Erasmus Wilson to give me a note as to the leper mentioned by White, he has kindly presented me with two handsome volumes containing lis lectures on Dernatology, delivered in the Royal College of Surgeons, Fingland, 1871-5.

In this work there is a very valuable chapter on Leprosy. He says: "In the early days the word 'Lejra,' expressive of roughness, was employed as a generic term to distinguish all cutaneous diseases that were not otherwise characterised by 'smoothness,' 'colour,' or 'magnitude ;' and the Arabian physicians adopted the word lepra as the synonym of the disease named by the Greeks 'elephantiasis;' hence, at the present time Elephantiasis GracoVOL. II. 
rum and Lepra Arabium must be regarded as synonymous terms, and elephantiasis in some parts of Europe is still spoken of as lepra. It was under the popular name of leprosy that elephantiasis spread as an epidemic thronghout England, Wales, Ireland, and Scotland, and had its home in Great Britain for fifteen centuries." It is stated by authors that the lepers are the type of the satyrs of the poets; this idea was remarkably illustrated by a case which came under the treatment of Professor Erasmus Wilson. He then contimnes as to the cause. "The danger is greatest at the nutritive period of life, when growth is active, and when the organization is busily attracting from withont air and food in abundaut quantities and with considerable energy. It may therefore be assumed that in certain countries, the cause, whether atmospheric or telluric, is constantly present, and that all that is necessary to give origin to the disease is a predisposition engendered by dehility proceeding from whatever cause."

There is another kind of leprosy, the Lepra Alphos of the Greeks, or common white leprosy. It is an eruption of the integument, distinguished by the presence of a white scale looking us if it were stuck upon the skin like a wafer, and of a circular tigure. I have in iny library a remarkable book by Richard Mead, entitled, Mcdica Sacra, 1749. Dr. Mead here gives diagnoses of the maladies which affected Job, Saul, Hezekiah, Nebuchadnezzar, \&c. His account of the leprosy of the Jews is exceedingly interesting. He takes his text from Leviticus, chap. xiii. 14, and admires the sanitary regulations laid down by Moses. He seems to consider that the disease under which Job suffered was Elephantiasis Grecorum.

The BLack Death of A.D. 1348.-I cannot here resist giving a short account of this terrible disease, which, like the leprosy, has now happily ceased to exist in England. When examining the monuments in the cloisters of Westminster Abbey, I found in the south eloister, on the large tombstone of Abbas Du Blois who died A.D. 1100, the following inseription, which has been eut in since my father's reign as dean. Dr. Stanley has caused to be reeorded that, under this very stone lie the remains of "twenty-six monks of Westminster, who died of the black death in 1348." Being desirous of knowing something abont the " black death," I consulted my learued friend, Signor Valetta, who writes me:- "The black death of 1348 must have been the same which, coming from Asia, ravaged Italy, killed the famous Laura of Petrarch, and was the theme of the famous Decameron of Boceaccio, that is to say, of the "one hundred novels' told in ten days by a party of ladies and gentlemen in a 
villa near Florence-Decameron, from the Greek, meaning ten days. I subjoin the authority of B. Lambert in the History and Survey of London, \&e.- . . "Were soon damped by a terrible pestilence, which is said to have spreal from India over all the country vestward of it, and reached England in 1348, where it destroyed immense numbers of the inhabitants, so that it was computed that in the city of London no more than one in ten survived the mortality. ... I I hear from the Rev. Mr. Maskell, of Emmanuel Hospital, that many thousands were buried in the environs of Charter House, \&c. Boccaccio asserts, in his preface to his Decameron, that in Florence alone the distemper carried away some one hundred thousand souls!"

I find that it is not generally known to my friends that the triangular space of ground just in front of Tattersall's gate, near the top of Sloane Street, is railed round because it is consecrated ground. At the time of the plague of London, this locality was quite in the suburbs, and there was a plagne pit here, wherein a vast number of people who died of this disease were interred.

Phroming Pigeons, p. 253.-In January.1874, a Frenchman was going about the neighbourhood of Regent's Park with performing pigeons. It was very interesting to notice how well he had trained these pretty birds. When at work one morning I heard a trumpet sounded, and upon looking out of the window, I saw the man with his pigeons. The birds were sitting on the top of a sort of ornamental cage, and at a given signal they all flew off with great rapidity up the street. They flew right away, keeping about the height of the top of an omnibus, for about 100 to 150 yards ; they then wheeled about suddenly, and returned to their master, and, one by one, alighted on the handle of a red flag which he was continually waving in the air. Nearly all the while the birds were flying the man blew his trumpet, and at times sounded a shrill whistle. Occasionally the birds went away over the tops of houses, and returned with a beautiful rush round the corner by a street different from that where they started. A gentleman living opposite me keeps a number of pigeons at the top of his house; and it was most interesting to observe the actions of these tame pigeons, who evidently were exceedingly astonished to see the performing pigeous go through their flight. Some of these trained pigeons hovered in the air almost as though fixed there with wire; I liave never seen the hovering so well marked. I forgot to mention that during the flight of these birds one in particular perches on the top of a house, and remains there till called by some peculiar signal. 
“Chinese Pigeon-Whistles."-My friend, Lady Dorothy Neville of Dangstein, Petersfield, has in her possession some most ingenious Chinese pigeon-whistles; they are simply light gourds cut so that a whistle is produced when the wind blows into them. These whistles are fastened on to the backs of the pigeons by a very fine wire or string; when the birds pass through the air a very melodious note is produced, reminding me much of the sound of many Eolian harps. The whistles giving different notes are fastened on to the backs of various pigeons, and when many of them are in the air the sound is very striking, and most beautiful.

Ecroes, p. 217.-When my fattherwas officiating in Westminster Abbey, he was always heard distinctly even by those at a distance. He told me that he waited till the echo of the voice came back to him; he was then sure the sound had gone as far as it could. His rule when speaking in public was to address himself to some person who was standing at the extreme end of the room. If this person showed by his actions that he could hear, it might be taken for granted that every one between the speaker and the listener in the distance could hear also. I myself have found this advice of great use. Every large assembly-room has its "key-note." I believe it is the practice of singers to get the "key-note" of a roomsuch as the theatre at Oxford-before they sing in public. I must not omit a story of Westminster Abbey. In former times the windows were out of repair, and the place full of draughts. A gentleman about to preach remarked to the old verger that he was afraid he should not be heard. The verger calmly answered, "Never fear, sir ; the wind is in your favour."

One of the most celebrated whispering places is the gallery in the dome of St. laul's, of whicl I read, "A whisper may be sent all round the dome. And not only in the gallery below but above, and upon the scaffold, I tried and found that a whisper would be carried over one's head, round the top of the arch, notwithstanding there is a large opening in the middle of it into the upper part of the dome." I understand that there is a remarkable whispering place in Gloucester Cathedral, above the east end of the choir.

Mole-Crickets, p. 24:3.-I lave had under observation two or three mole crickets, kindly sent me by Mr. Pemny, of Poole. I kept them in a finger-glass on the mantelpiece, but they did not seem to care to bury themselves in the earth unless annoyed; they would feed greedily on worms, which they ate in a peculiar 
manner, which I have not space here to describe. The thoracic portion of the body is defended by a sort of cuirass, adnurably adapted to bear the weight of the superincumbert earth. The anatomy of the mole-cricket has been thoroughly rleseribed by Dr. Kidd, late Regius Professor at Oxford, Philos. Trans., 115, (1825), p. 228. The preparations (611 and 784) of the Royal College of Surgeons slow the anatomy of the mole-cricket. The crop, instead of being a gradual dilatation of the osophagns, is appended to the side of that tube, like the crop of a fowl, and a longer canal intervenes between it and the gizzard; two large cæcal appendages open into the termination of the gizzard, from which the true digestive. stomach is continued. 'The liver is represented by a great number, from 150 to 200 , of minute but long capillary ceca which all unite into one common tube or duet, which conveys the biliary secretion into the intestinal canal, close to the pylorus.

Flamingo, p. 248.-Probable Origin of the Old Story of the Pelican in the Wilderness Feeding íts Young on its own BLOOD. - When a boy at Winchester College I was always much struck with the representations of the pelican feeding its young with its own blood, which adom the roof of the grand old Cathedral at Winchester. Mentioning this one day to Mr. Bartlett, lie told me that he had discovered the origin of this story, and he kindly gave me lis observations in writing as follows:-

"The facts I now lay belore you appear to me to afford a solution to the well-known and ancient story of the Pelican in the Wilderness. I have heard that the so-called fable originated, or is to be found, on some of the early Egyptian rnonuments (I do not know where), but that the representations are more like flamingoes than pelicans. I have published in the "Proceedings of the Zoological Soniety," March 1869, what I consider to be the facts of the case. The flamingoes in the gardens lave frequently shown signs of breeding, and have been supplied with heaps of sand to form their nests, but without result; nevertheless they appear to take considerable notice of a pair of eariamas in the same aviary. These bircls have a liabit of bending back their heads, and with open gaping mouths utter loud and somewhat distressing sounds. This habit at once attracts the flamingoes, and very frequently one or more of them advance towards the cariamas, and standing erect over the bird, by a slight up and down movement of the head, raise up into its mouth a cousiderable quantity of recl-coloured fluid, which, as soon as the upper part of the throat and mouth becomes filled, it will drop or run down from the corners of the Hamingo's 
mouth; the flamingo then bends its long neck over the gaping cariama and pours this fluid into the mouth, and as frequently on the back of the cariama. Having seen this repeatedly $I$ took an opportunity of obtaining a portion of this fluid, and submitted it to the examination of Dr. Murie. We placed it under the microscope and found it composed of little else than blood; in fact the red blood-corpuseles are wonderfully abundant in the otherwise clear and almost transparent glutinous fluid. That this does not proceed from any disease or injury done to the flamingo, nor arise from or is produced by any portion or part of the food taken by them, I am perfectly certain, for the birds are in the most vigorous health and condition; but I believe that it is an attempt to supply food to the cariamas, just as the hedge-sparrow and other birds supply food to the young cuckoo ; and I have no doubt if a careful observer lad the opportunity of watching the flamingoes on their breeding-gromnd, he would find that this is the mode of feeding their young; no doubt other food is also provided, but most likely mixed with this secretion. I think it highly probable that this liabit was noticed in ancient Fgypt, and, by the confusion of names in translation, the pelican was supposed to be the bird intended; in fact I lave heard that the representation (which I am very anxious to see) is much more like a flarningo than a pelican. Again, a flamingo is much more a bird of the wilderness than the pelican, seeing that the pelican requires a good supply of fish, while the flamingo can live and does well upon very small insects, seeds, \&c., and is found in places in which the pelican would starve." 


\section{THE ANTIQUITIES OF SELBORNE \\ IN THE}

COUNTY OF SOUTHAMPTON.

Desertosque videre locos . . . . VIrGIL. 



\section{ANTIQUITIES OF SELBORNE.}

\section{LETTER I.}

IT is reasonable to suppose that in remote ages this woody and mountainons district was inhabited only by bears and wolves. Whether the Britons ever thought it worthy their attention is not in our power to determine; but we may safely conclude, from circumstances, that it was not unknown to the Romans. Old people remember to have heard their fathers and grandfathers say that, in dry summers and in windy weather, pieces of money were sometimes found round the verge of Wolmer. Pond; and tradition had inspired the foresters with a notion that the bottom of that lake contained great stores of treasure. During the spring and summer of 1740 there was little rain; and the following summer also, .7741, was so uncommonly dry, that many springs and ponds failed, and this lake in particular, whose bed became as dusty as the surrounding heaths and wastes. This favourable juncture induced some of the forest cottagers to begin a search, which was attended with such success that all the labourers in the neighbourhood flocked to the spot, and with spades and hoes turned up great part of that large area. Instead of pots of coins, as they expected, they found great heaps, the one lying on the other, as if shot out of a bag; many of which were in good preservation. Silver and gold these inquirers expected to find; but their discoveries consisted solely of many liundreds of Roman copper coins and some VOL. II. 
[LETT.

medallions, all of the lower enpire. There was not much virtì stirring at that time in this neighbourhood; however, some of the gentry and clergy around bought what pleased them best; and some dozens fell to the share of the author.

The owners at first held their commodity at a high price, but, finding that they were not likely to meet with dealers at such a rate, they soon lowered their terms, and sold the fairest

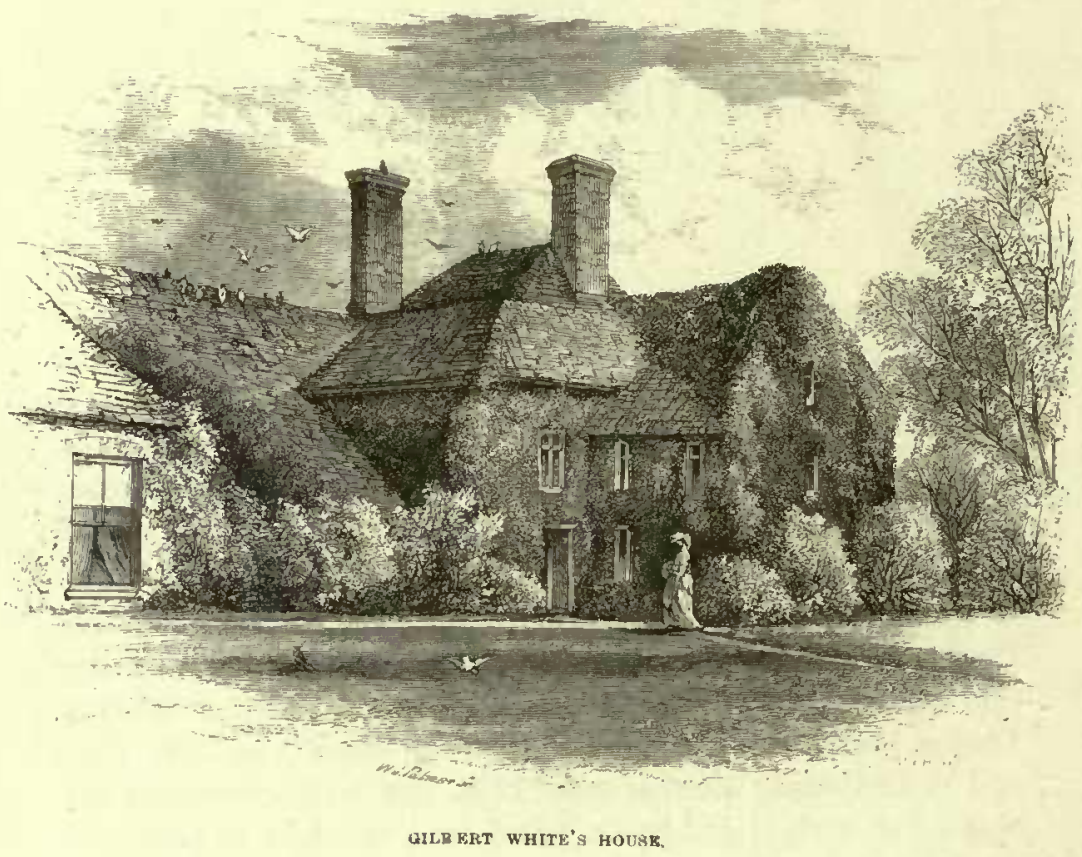

as they could. The coins that were rejected became current, and passed for farthings at the petty shops. Of those that we saw, the greater part were of Marcus Aurelius, and the Empress Faustina, his wife, the father and mother of Commodus. Some of Faustina were in high relief, and exhibited a very agreeable set of features, which probably resembled that lady. The medallions in general were of a paler colour than the coins. 'To pretend to account for the means of their coming to this 
place would be spending time in conjecture. The spot, I think, could not be a Roman camp, because it is commanded by hills on two sides; nor does it show the least traces of intrenchments; nor can I suppose that it was a Roman town, because I have too good an opinion of the taste and judgment of those polished conquerors to imagine that they would settle on so barren and dreary a waste.

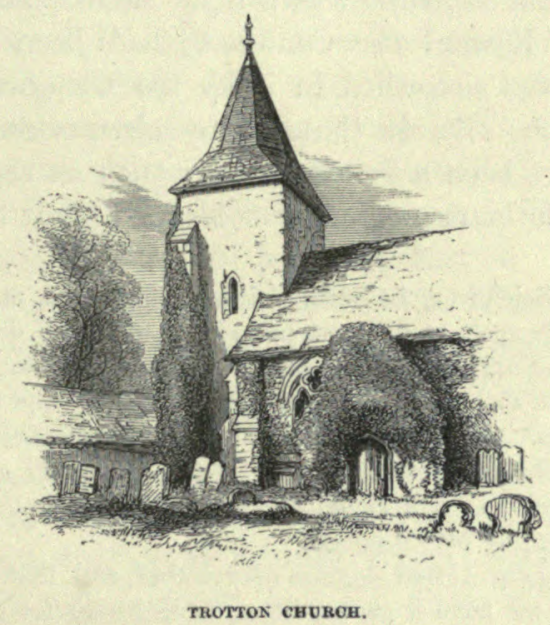




\section{LETTER II.}

That Selborne was a place of some distinction and note in the time of the Saxons we can give most undoubted proofs. But as there are few, if any, accounts of villages before Domesday, it will be best to begin with that venerable record. "Ipse rex tenet Selesburne. Eddid regina tenuit, et nunquam geldavit. De isto manerio dono dedit rex Radfredo presbytero dimidiam hidam cum ecclesia. Tempore regis Edwardi et post, valuit duodecim solidos et sex denarios; modo octo solidos et quatuor denarios." Here we see that Selborne was a royal manor; and that Editha the queen of Edward the Confessor, had been lady of that manor; and was succeeded in it by the Conqueror; and that it had a church. Beside these, many circumstances concur to prove it to have been a Saxon village; such as the name of the place itself, ${ }^{1}$ the names of many fields, and some families, ${ }^{2}$ with

1 Selesburne, Seleburne, Selburn, Selbourn, Solborne, and Selborn, as it has been variously spelt at different periods, is of Saxon derivation; for Se signifies great, and burn torrents, a brook or rivulet: so that the name seems to be derived from the great perennial stream that breaks out at the upper end of the village. Sel a'so signifies bonus, item, focundus, fertilis. "belsæpr-cun : facunda graminis clausura; fertile pascuum: a meadow in the parisl of Godelming is still called Sal-gars-ton."-LrE's Saxon Dictionary, in the Supplement, by Mr. Manning.

2 Thus the name of Aldred signifies all-revercnd, and that of Kemp means a soldier. Thus we have a church-litton, or inclosure for dead bodies, and not a church-yard: there is also a Culver-craft near the Grange-farm, being the inclosure where the priory pigeon-house stood, from culver a pigeon. Again there are three steep pastures in this parish called the Lithc, from Hithe, clivus. The wicker-work that binds and fastens down a hedge on the top is called ether, from ether a hedge. When the good women call their hogs they cry sic, sic, ${ }^{1}$ not knowing that sic is Saxon, or rather Celtic, for a hog. Coppice or brushwood our countrymen call rise, from hris, frondes; and talk of a load of rise. Within the author's memory the Siuxon plurals, housen and peason, were in common use. But it wonld be endless to instance in every circumstance: he that wishes for more specimens must

r " "ika, porcus, apud Lacones ; un porceau chez les Iacédemoniens: ce mot a sans doute esté pris des Celtes, qui discent sic pour inarquer un porceau. Encore aujour'hiy quand les Bretons chassent ces animax, Is ne disent point autrement que sic, sic." - Antiquite de la Nation et de la Langue des Celtes, par PEzton. 
a variety of words in husbandry and common life, still subsisting among the country people.

What probably first drew the attention of the Saxons to this spot was the beautiful spring or fountain called Well-head, ${ }^{1}$ which induced them to build by the banks of that perenmial current; for ancient settlers loved to reside by brooks and rivulets, where they could dip for their water without the trouble and expense of digging wells and of drawing.

It remains still unsettled among the antiquaries at what time tracts of land were first appropriated to the chase alone for the amusement of the sovereign. Whether our Saxon monarehs had any royal forests does not, I believe, appear on record; but the Constitutioncs de Foresta of Camute, the Dame, are come down to us. We shall not therefore pretend to say whether Wolmer Forest existed as a royal domain before the conquest. If it did not, we may suppose it was laid out by some of our earliest Norman kings, who were exceedingly attached to the pleasures of the chase, and resided much at Winchester, which lies at a moderate distance from this district. The Plantagenet princes seem to have been pleased with Wolmer; for tradition says that King John resided just upon the verge, at Wardlehan, on a regular and remarkable mount, still called King John's Hill, and Lodge Hill; and Edward III. had a chapel in his park, or inclosure, at Kingsley. ${ }^{2}$ Humphrey, Duke of Gloucester, and Richard, Duke of York, say my evidences, were both, in their turus, wardens of Wolmer Forest; which seems to have served for an appointment for the younger princes of the royal family, as it may again.

I have intentionally mentioned Edward III. and the Dukes Humphrey and Richard before Ining Edward II., because ] have reserved for the entertaimment of my readers a pleasant

frequent a farmer's kitchen. I have therefore selected some words to show how familiar the Saxon dialect was to this district, since in more than seven hundred years it is far from being obliterated.

1 Well-head signifies spring-head, and not a deep pit from whence we draw water.-For particulars about which see Letter I. to Mr. Pennant.

2 The parish of Kingsley lies between, and divides Wolmer Forest from Ayles Holt Forest.-See Letter IX. to Mr. Pennant. 
anecdote respecting that prince, with which I shall close this letter.

As Edward II. was hunting in Wolmer Forest, Morris Ken, of the kitchen, fell from his horse several tirnes; at which accidents the king laughed immoderately: and, when the chase was over, ordered him twenty shillings $;^{1}$ an enormous sum for those days! Proper allowances ought to be made for the youth of this monarch, whose spirits also, we may suppose, were much exhilarated by the sport of the day: but, at the same time, it is reasonable to remark that, whatever might be the occasion of Ken's first fall, the subsequent ones seem to have been designed. The scullion appears to have been an artful fellow, and to have seen the king's foible; which furnishes an early specimen that his easy softness and facility of temper, of which the infamous Gaveston took such advantages as brought innumerable calamities on the nation, and involved the prince at last in misfortunes and sufferings too deplorable to be rnentioned without horror and amazement.

\section{LETTER III}

From the silence of Domesday respecting churches, it has been supposed that few villages had any at the time when that record was taken; but Selborne, we see, enjoyed the benefit of one: hence we may conclude that this place was in no abject state even at that very distant period. How many fabrics have succeeded each other since the days of Radfredrus the presbyter, we cannot pretend to say; our business leads us to a description of the present edifice, in which we shall be circumstantial.

Our church, which was dedicated to the Virgin Mary, consists of three aisles, and measures fifty-four feet in length by forty-

2 "Item, paid at the lodge at Wolmer, when the king was stag-hunting there, to Morris Ken, of the kitchen, because he rode before the king and often fell from his horse, at which the king laughed exceedingly-a gift, by command, of twenty shillings."-A MS. in possession of Thoinas Astle, Esq., containing the private expenses of Edward II. 
seven in breadth, being almost as broad as it is long. The present building has no pretensions to antiquity; and is, as I suppose, of no earlier date than the beginning of the reign of Henry VII. It is perfectly plain and uxadorned, without painted glass, carved work, sculpture, or tracery. But when I say it has no claim to antiquity, I would mean to be under-

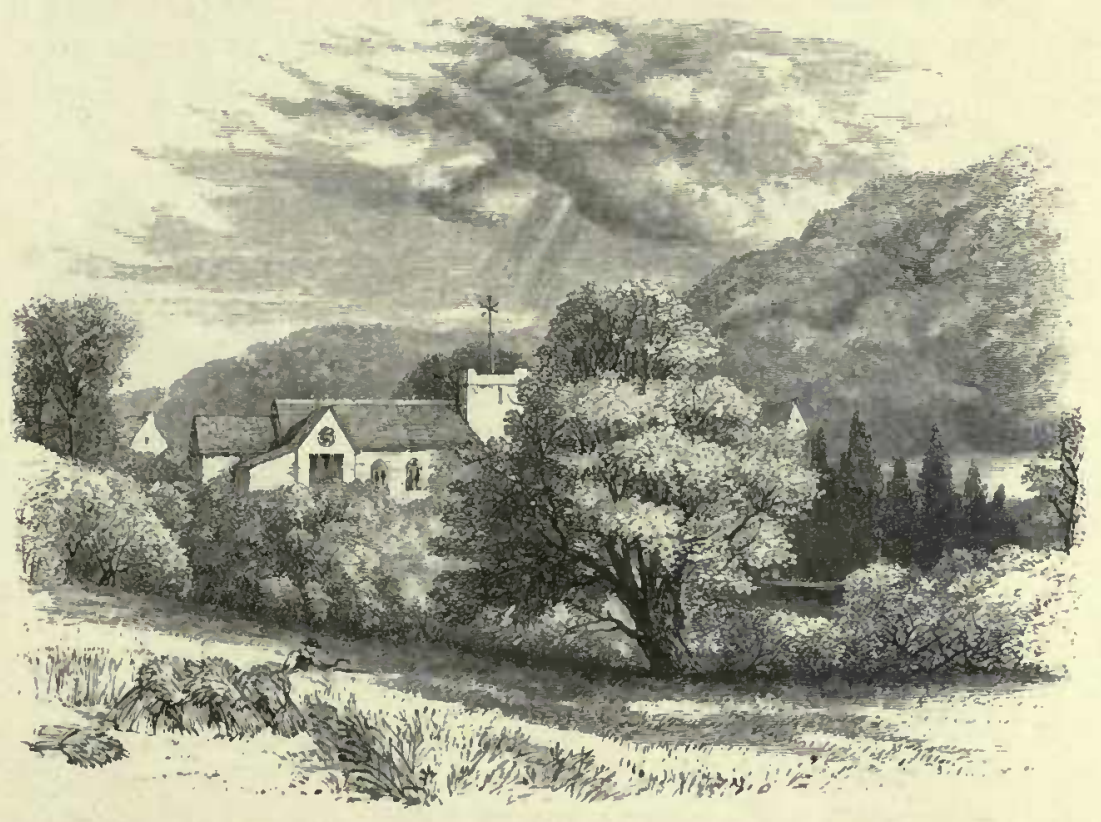

VIEW OF GRLBORXY CHURCH PROM THY AITOS KOAD,

stood of the fabric in general; for the pillars which support the roof are undoubtedly old, being of that low, squat, thick order, usually called Saxon. These, I should imagine, upheld the roof of a former church, which falling into lecay, was rebuilt on those massy props, because their strength had preserved them from the injuries of time. ${ }^{1}$ Upon these rest blunt

In the same manner, to compare great things with small, did Wykeham, when he new-built the cuthedral at Winchester, from the tower westwiurd, 
Gothic arehes, suel as prevailed in the reign above mentioned, and by which, as a eriterion, we would prove the date of the building.

At the bottom of the south aisle, between the west and south doors, stands the font, whieh is deep and eapacious, and eonsists of three massy round stones, piled one on another, without the least ornament or senlpture: the cavity at the top is lined with

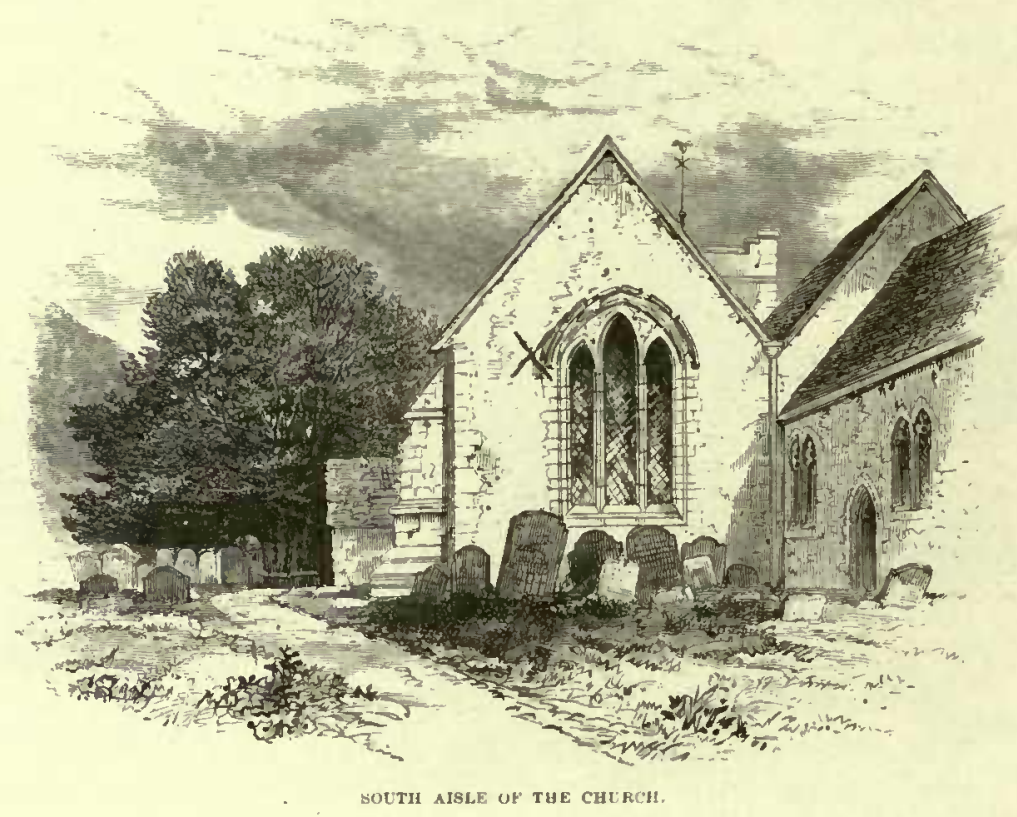

lead, and has a pipe at bottom to convey off the water after the sacred eeremony is performed.

The east end of the south aisle is called the South Chancel, and, till within these thirty years, was divided off by old carved Gothic frame-work of timber, having been a private chantry. In this opinion we are more confirmed by observing two

apply to his purpose the old piers or pillars of Bishop Walkelin's church, by blending Saxon and Gothic architecture together.-See LowTr's Life of Wykeham. 
Gothic niches within the space, the one in the east wall and the other in the south, near which there probably stood images and altars.

In the midule aisle there is nothing remarkable: but I remember when its beams were hung with garlands in honour of young woinen of the parish, reputed to lave died virgins; and recollect to have seen the clerk's wife cutting, in white paper, thie resemblances of gloves, and ribbons to be twisted into knots and roses, to decorate these memorials of chastity. In the chmreh of Faringdon, which is the next parish, many garlands of this sort still remain.

The nortl a aisle is narrow and low, with a sloping ceiling, reaching within eight or nine feet of the floor. It had originally a flat roof covered with lead, till, within a century past, a ehurchwarden stripping off the lead, in order, as he said, to lave it mended, sold it to a plumber, and ran away with the money. This aisle has no door, for an obvious reason; because the north side of the churchyard, being surrouncled by the vicarnge garden, affords no path to that side of the church. Nothing can be more irregular than the pews of this church, which are of all dimensions and heights, being patched up according to the fancy of the owners: but whoever nicely examines them will find that the middle aisle had, on each side, a regular row of benches of solid oak, all alike, with a low back-board to eacl. These we should not hesitate to say are coeval with the present church: and especially as it is to be observed that, at their ends, they are ornamented with carved blunt Gotlic niches, exactly correspondent to the arches of the ehurch, to a niche in the south wall. The south aisle also has a row of these benches, but some are decayed through age, and the rest much disguised by modern alterations.

At the upper end of this aisle, and runuing out to the north, stauls a transept, known by the name of the North Chancel, measuring twenty-one feet frum south to north, and nineteen feet from east to west: this was intended, no doubt, as a private chantry ; and was also, till of late, divided off by a Gothic framework of timber. In its north wall, under a very blunt Gothic arch lies perhaps the fouuder of this edifice, which, from the shape VOL. II. 
of its arch, may be deemed no older than the latter end of the reign of Henry VII. The tomb was examined some years ago, but contained nothing except the skull and thigh bones of a large tall man, the bones of a youth or woman, lying in a very irregular manner, without any escuteheon or other token to ascertain the names or rank of the deceased. The grave was very shallow, and lined with stone at the bottom and on the sides.

From the east wall project four stone brackets, which I conclucle supported images and erucifixes. In the great thick

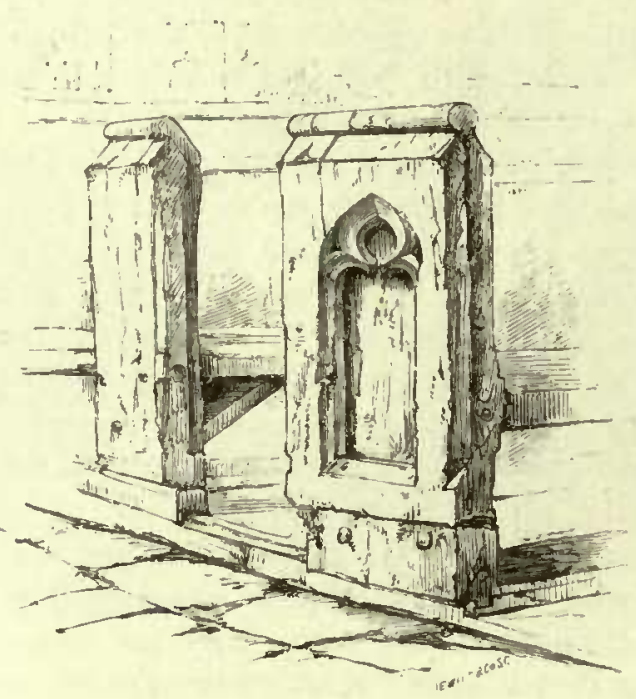

ORIGINAL BKXTHES IS SOITH AISIF OF THE RHIRCH.

pilaster, jutting out between this transept and the ehaneel, there is a very sharp Gothic niche, of older date than the present ehantry or eliurch. But the ehief pieees of antiquity are two narrow strone coffin lids, which compose part of the Hoor, and lie from west to east, with the very narrow ends enstward: these belong to remote times; and, if originally placed here, which I dount, must have been part of the pavement of an older transept. At present there are $n o$ coffins 
under them, whence I conclude they lave been removed to this place from some part of a former church. One of these lids is so eaten by time, that no sculpture ean be discovered on it; or, perhaps, it may be the wrong side uppermust: but on the other, which seems to be of stone of a closer and harcler texture, is to he discerned a discus, with a cross on it, at

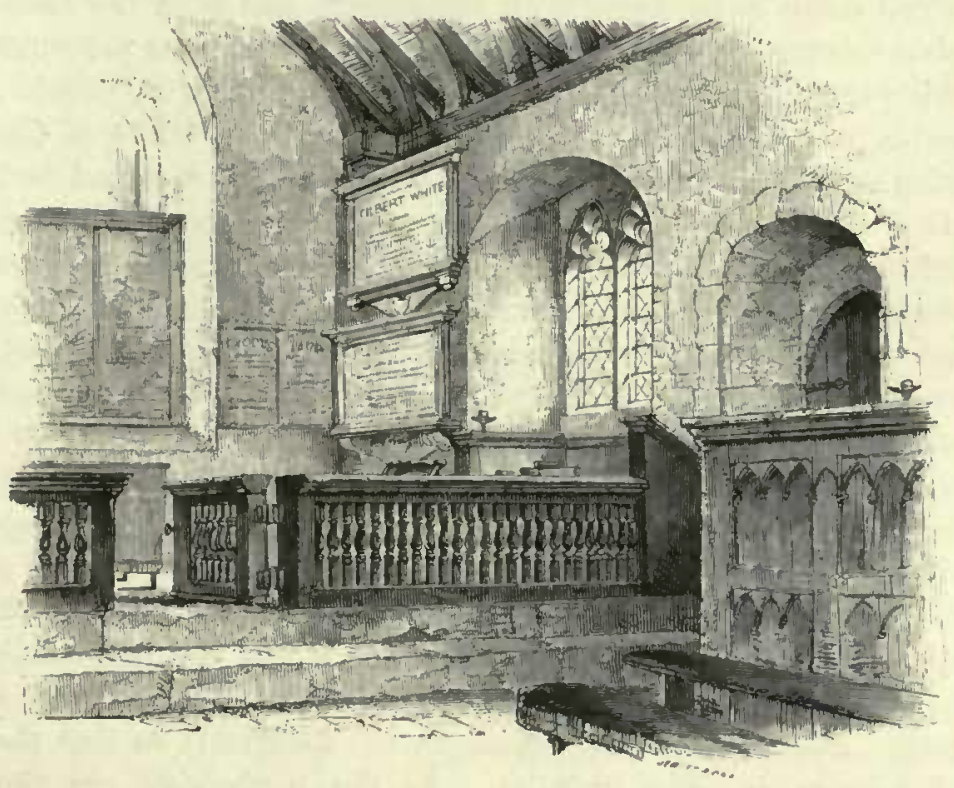

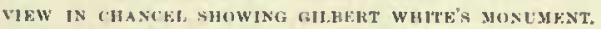

the end of a staff or rod, the well known symbol of a Knight Templar. ${ }^{1}$

This order was distinguished by a red cross on the left shoulder of their cloak, and by this attribute in their hand. Now, if these stones belonged to Knights Templars, they must have lain here many centuries; for this order came into England early in the reign of King Stephen in 1113 ; and was dissolver in the time of Edward II. in 1312, having subsisted only one

'See Dugdale, "Monasticon Anglicanum," vol. ii, where there is a fine engraving of a Knight Templar, by Hollar. 
[LETT.

hundred and ninety-nine years. Why I should suppose that Knights Templars were occasionally buried at this ehureh will appear in some future letter, when we come to treat more particularly concerning the property they possessed here, and the intereourse that subsisted between them and the priors of Selborne.

We must now proceed to the ehancel, properly so ealled, which seems to be eoeval with the ehurch, and is in the same plain unadorned style, though neatly kept. This room measures thirty-one feet in length, and sixteen feet and a half in breadth, and is wainscoted all round, as high as to the bottom of the windows. The space for the eommunion table is raised two steps above the rest of the floor, and railed in with oaken balusters. Here I shall say somewhat of the windows of the ehancel in partieular, and of the whole fabrie in general. They are mostly of that simple and unadorned sort ealled Laneet, some single, some double, and some in triplets. At the east end of the chancel are two of a moderate size, near each other; and in the north wall two very distant small ones, unequal in length and height: and in the soutl wail are two, one ou each side of the chancel door, that are broad and squat, and of a different order. At the east end of the south aisle of the ehureh there is a large lancet-window in a triplet; and two very small, narrow single ones in the south wall, and a broad squat window beside, and a double laneet one in the west end; so that the appearance is very irregular. In the north aisle are two windows, made shorter when the roof was sloped; and in the north transept a large triple window, shortened at the time of a repair in 1721; when over it was opened a round one of considerable size, which affords an agreeable light, and renders that ehantry the most chcerful part of the edifice.

The chureh and chancels have all coved roofs, ceiled about the year 1683 ; before which they were open to the tiles and shingles, showing the naked rafters, and tbreatening the congregation with the fall of a spar, or a blow from a piece of loose mortar.

On the north wall of the chancel is fixed a large oval white marble monument, with the following inscription; and at the 


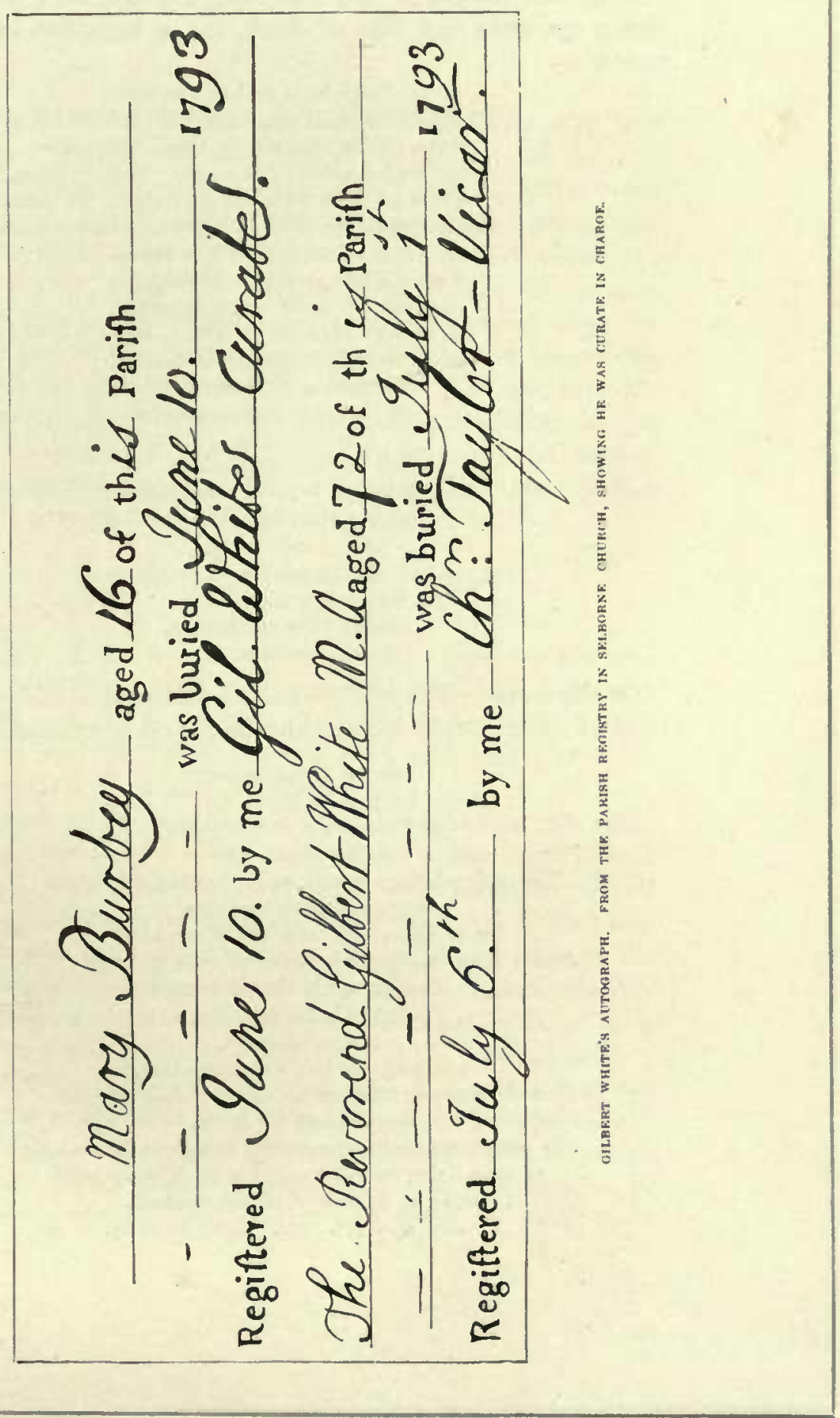


foot of the wall, over the deceased, and inscribed with his name, age, arms, and time of deatli, lies a large slab of black marble:-

\section{Prope hunc parictem sepelitur \\ GILBERTUS WHITE, SAMSONIS WHITE, de}

Oxon. militis filius tertius, Collegii Magdale-nensis ibidem alumnus, \& socius. Tandem favente collegio ad lane ccelesiam promotus; ubi prime-vâ morum simplicitate, et diffusâ erga ounnes bene-volentiâ feliciter consenuit.

Pastor fidelis, comis, affabilis,

Maritns, et pater annantissimus,

A conjuge invicem, et liberis, atque

A parochianis, impensé dilectus.

Pauperibus ita beneficus

ut decimam partem censûs moribundns

piis usibus consecravit.

Meritis demum juxta et annis plenus ex hac vitâ migravit Feb. $13^{\circ}$ anno salutis $12 \tau$.

Attatis sux 77.

Hoc posuit Rebecca

Conjux illius mæstissima, mox secutura.

On the same wall is newly fixed a small square table monunent of white marble, inscribed in the following manner:--

Sacred to the memory

of the Revil. ANDREW ETTY, B.D.

23 Yeurs Vicar of this parisl :

In whose charactcr

The conjugal, the parental, and the sacerdotal virtues were so happily combined

as to deserve the imitation of mankind.

And if in any particular he followed more invariably

the steps of his blessed Master,

It was in his humility.

His parishioners,

especially the sick and necessitous,

as long as ally traces of his memory shall remain,

must lament his death.

To perpetuate such an example, this stone is erected;

as while living he was a preacher of righteousness,

so, by it, he being dead yet speaketh.

He died April $8^{\text {th }}$. 1784. Aged 66 years. 


\section{LETTER IV.}

WE have now taken leave of the inside of the church, and shall pass by a door at the west end of the middle aisle into the belfry. This room is part of a handsome square embattled tower of forty-five feet in height, and of much more modern date than the chureh; but old enough to have needed a thorough lepair in 1781, when it was neatly stnceoed at a considerable expense, by a set of workmen who were employed on it for the greatest part of the summer. The old bells, three in number, loud and out of tune, were takels down in 1735 , and east into four; to which Sir Simeon Stuart, the grandfather of the present baronet, added a fifth at his own expense: and, bestowing it in the name of his favourite daughter, Mrs. Mary Stuart, caused it to be cast with the following motto round it:--

"Clara puelia dedit, dixitque mihi esto Maria :

Illius et laudes nomen ad astrit sono."

The day of the arrival of this tuneable peal was observed as a high festival by the village, and rendered more joyous by an order from the donor that the treble bell should be fixed bottom upward in the ground and filled with punch, of which all present were permitted to partake.

The porch of the chureh, to the south, is modern, and would not be worthy attention did it not shelter a fine sharp Gothic cloorway. This is undoubtedly much older than the present fabric; and being found in good preservation, was worked into the wall, and is the grand entrance into the church: nor are the folding doors to be passed over in silence; since from their thick and clumsy structure, and the rude flourished work of their hinges, they may possibly be as ancient as the doorway itself.

The whole roof of the south aisle, and the south side of the roof of the middle aisle, is covered with oaken shingles instead of tiles, on account of their lightuess, which favours the ancient and crazy timber frame. And indeed, the consideration of accidents by fire excepted, this sort of roofing is much more 
eligible than tiles. For shingles well seasoned, and cleft from quartered timber, never warp, nor let in drifting snow; nor do they shiver with frost; nor are they liable to be blown off like tiles; but when well nailed down, last for a long period, as experience has shown us in this place, where those that face to

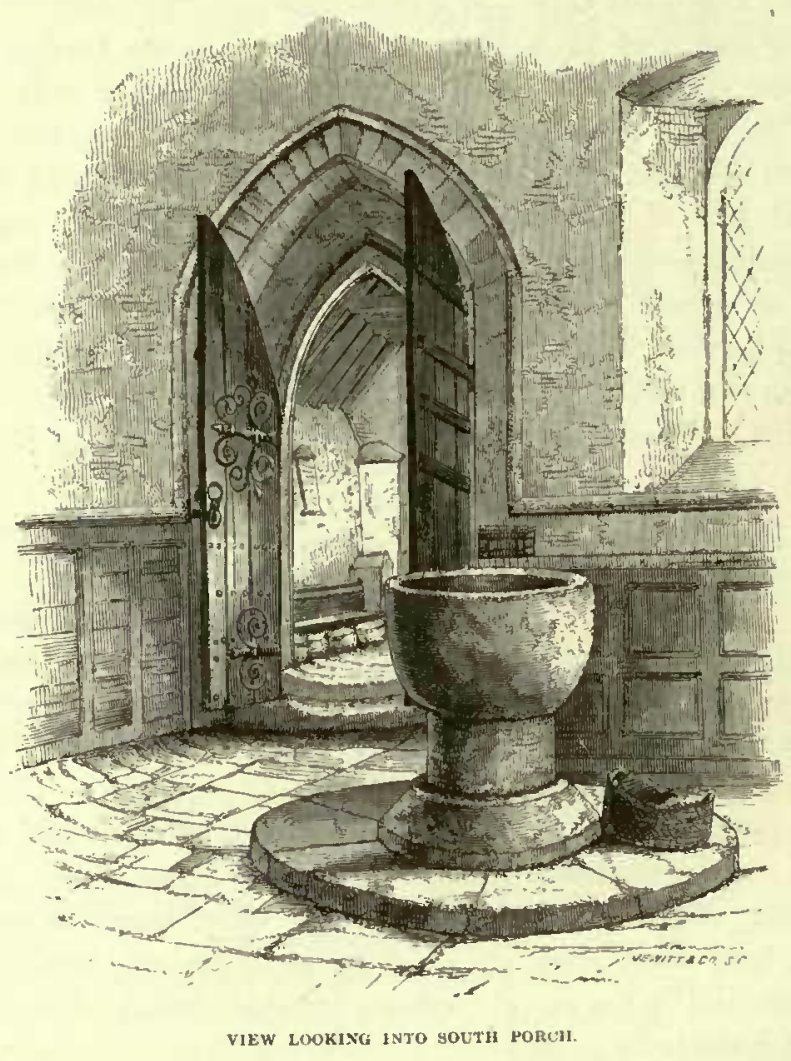

the north are known to have endured, untouched, by undoubted tradition for more than a century.

Considering the size of the church, and the extent of the parish, the churchyard is very scanty; and especially as all wish to be buried on the south side, which is become such a mass of mortality that no person can be there interred without 
disturbing or displacing the bones of his ancestors. There is reason to suppose that it once was larger, and extended to what is now the vicarage court and garden; because many human bones have been dug up in those parts several yards without the present limits. At the east end are a few graves; yet none till very lately on the north side; but, as two or three families of best repute have begnn to bury in that quarter, prejudice may wear out by degrees, and their example be followed by the rest of the neighbourhood.

In speaking of the church, I have all along talked of the east and west end, as if the chancel stood exactly true to those points of the compass; but this is by no means the case, for the fabric bcars so much to the north of the east, that the four corners of the tower, and not the four sides, stand to the four cardinal points. The best method of accounting for this deviation seems to be, that the workmen, who probably were employed in the longest days, endeavoured to set the chancels to the rising of the sun.

Close by the church, at the west end, stands the vicarage house; all old but roomy and convenient edifice. It faces very agreeably to the morning sun, and is divided from the village by a neat and cheerful court. According to the manner of old times, the hall was open to the roof; and so continued, probably, till the vicars became family-men, and began to want more conveniences; when they flung a floor across, and, by partitions, divided the space into chambers. In this hall we remember a date, some time in the reign of Elizabeth; it was over the door that leads to the stairs.

Behind the house is a garden of an irregular shape, but well laid out; whose terrace commands so romantic and picturesque a prospect, that the first master in landscape might contemplate it with pleasure, and deem it an object well worthy of his pencil. 


\section{LETTER V.}

In the churchyard of this village is a yew-tree, whose aspect bespeaks it to be of a great age: it seems to have seen several centuries, and is probably coeval with the church, and therefore may be deemed an antiquity: the body is squat, short, and thick, and measures twenty-three feet in the girth, supporting a head of suitable extent to its bulk. This is a male tree, which in the spring sheds clouds of dust, and fills the atmosphere around with its farina.

As far as we have been able to observe, the males of this species become much larger than the females; and it has so fallen out that most of the yew-trees in the clurchyards of this neighbourhood are males: but this must have been matter of mere accident, since men, when they first planted yews, little dreamed that there were sexes in trees.

In a yard, in the midst of the street, till very lately grew a middle-sized female tree of the same species, which commonly bore great crops of berries. By the high winds usually prevailing about the autunnal equinox, these berries, then ripe, were blown down into the road, where the hogs ate then. And it was very remarkable, that, though barrow-hogs and young sows found no inconvenience from this food, yet milch-cows often died after such a repast: a circumstance that can be accounted for only by supposing that the latter, being much exhausted and hungry, devoured a larger quantity.

While mention is making of the bad effects of yew-berries, it may be proper to remind the unwary, that the twigs and leaves of yew, though eaten in a very small quantity, are certain death to horses and cows, and that in a few minutes. A horse tied to a yew hedge, or to a faggot stack of dead yew, shall be found dead before the owner can be aware that any danger is at hand: and the writer has been several times a sorrowful witness to losses of this kind among lis friends; and in the island of Ely had once the mortification to see mine young stcers or bullocks of his own all lying dead in a heap from browzing a 
little on a hedge of yew in an old garden into which they had broken in snowy weather. Even the elippings of a yew ledge lave destroyed a whole dairy of cows when thrown inadvertently into a yard. And yet sheep and turkeys, and, as parkkeepers say, deer will crop these trees with impunity.

Some intelligent persons assert that the branehes of yew, while green, are not noxious; and that they will kill only when dead and withered, by lacerating the stomach: but to this assertion we eannot by any means assent, because, among the

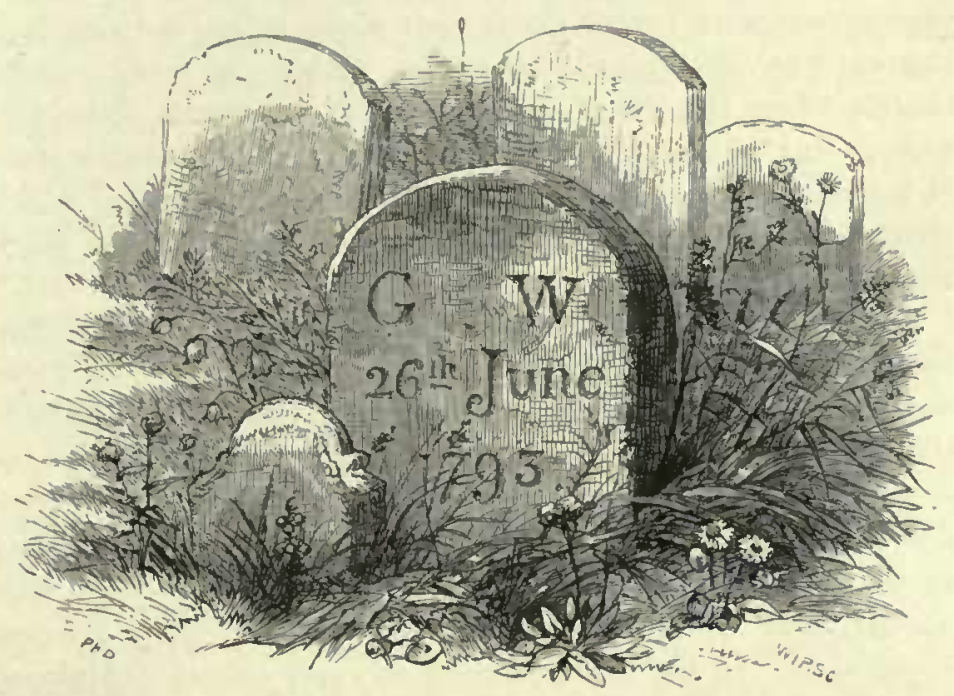

GRAVESTUNE: TO GH,BEHT WHTE. EAST END OF CHUKCHYARD

number of cattle that we have known fall victims to this deadly food, not one has been found, when it was opened, but had a lump of green yew in its paunch. True it is, that yew-trees stand for twenty years or more in a field, and no bad consequences ensue: but at some time or other cattle, either from wantonness when full, or from humger when empty (from both which eircunstances we have seen them perish), will be meddling, to their certain destruction; the yew seems to be a very improper tree for a pasture field. 
Antiquaries seem much at a loss to determine at what period this tree first obtained a place in churchyards. A statute passed A.D. 1307, and 35 Edward I, the title of which is "Ne rector arbores in cemeterio prosternat." Now if it is recollected that we seldom see any other very large or ancient tree in a churchyard but yews, this statute must have principally related to this species of tree; and consequently their being planted in churchyards is of much more ancient date than the year 1307 .

As to the use of these trees, possibly the more respectable parishioners were buried under their shade before the improper custom was introduced of burying within the body of the church, where the living are to assemble. Deborah, Rebekah's nurse, ${ }^{1}$ was buried under an oak; the most honourable place of interment probably next to the cave of Machpelah, ${ }^{2}$ which seems to have been appropriated to the remains of the patriarchal family alone.

The further use of yew-trees might be as a screen to churches, by their thick foliage, from the violence of winds; pcrhaps also for the purpose of archery, the best long bows being made of that material: and we do not hear that they are planted in the churchyards of other parts of Europe, where long bows were not so much in use. They might also be placed as a shelter to the congregation assenıbling before the church doors were opened, and as an emblem of mortality by their funereal appearance. In the south of England every churchyard almost lias its tree, and some two; but in the north, we understand, few are to be found.

The idea of $R$. C., that the yew-tree afforled its branches instead of palms for the processions on Palm Sunday, is a good one, and deserves attention.-See Gent. Mag., vol. i. p. 128.

$$
{ }^{1} \text { Gen, xxxy. 8. } \quad{ }^{2} \text { Gen. xxiii. } 9 .
$$




\section{LETTER VI.}

THE living of Selborne was a very small vicarage; but, being in the patronage of Magdalen College, in the University of Oxford, that society endowed it with the great tithes of Selborne, more than a century ago: and since the year 1758 again with the great titlies of Oakhanger, called Bene's Parsonage: so that, together, it is become a respectable picce of preferment, to which one of the fellows is alrays presented. The vicar holds the great tithes, by lease, under the college. The great disadvantage of this living is, that it has not one foot of glebe near home. ${ }^{1}$

ITS PAYMENTS ARE,

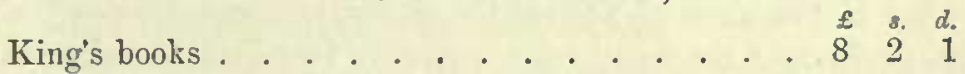

Yearly tenths . . . . . . . . . . . $0162 \frac{1}{2}$

Yearly procurations for Blackmore and Oakhanger

Chap: with acquit: . . . . . . . . . 017

Selborne procurations and acquit: . . . . . 090

I an unable to give a complete list of the vicars of this parish till towards the end of the reign of Queen Elizabeth; from which period the registers furnish a regular series.

In Domesday we find thus-" De isto manerio dono dedit Rex Radfredo presbytero dimidiam hidam cum ecclesia." So that before Domesday, which was compiled between the years 1081 and 1086, there was an officiating minister at this place.

After this, among nry documents, I find occasiowal mention of a vicar here and there: the first is

Roger, instituted in 1254.

In 1410 John Lynne was vicar of Selborne.

In 1411 Hugo Tybbe was viear.

The presentations to the vicarage of Selborne generally ran in the name of the prior and the convent; but Tybbe was presented by prior John Wynechestre only.

1 At Bene's, or Bin's, parsonage there is a house and stont barn, and seven acres of glebe. Bene's parsonare is three miles from the church. 
June 29, 1528, William Fisher, vicar of Selborne, resigned to Miles Peyrson.

1594. Willian White appears to have been vicar to this time. Of this person there is nothing remarkable, but that he hath made a regular entry twice in the register of Selborne of the funeral of Thomas Cowper, Bishop of Winchester; as if he had been buried at Selborne; yet this learned prelate, who died 1594, was buried at Winchester, in the eathedral, near the episcopal throne. ${ }^{1}$

1595, Richard Boughton, vicar.

1596, William Inkforbye, vicar.

May 1606, Thomas Phippes, vicar.

June 1631, Ralph Austine, vicar.

July 1632, John Longworth. This unfortunate gentleman, living in the time of Cromwell's usurpation, was deprived of his preferment for many years, probably because he would not take the league and covenant: for I observe that lis father-inlaw, the Reverend Jethro Beal, rector of Faringdon, which is the next parish, enjoyed his benefice during the whole of that unhappy period. Longworth, after he was dispossessed, retired to a little tenement about one hundred and fifty yards from the church, where he earned a small pittance by the practice of physic. During those dismal times it was not uncommon for the deposed clergy to take up a medical character; as was the case in particular, I know, with the Reverend Mr. Yalden, rector of Compton, near Guildford, in the county of Surrey. Vicar Longworth used frequently to mention to his sons, who told it to my relations, that, the Sunday after his deprivation, his puritanical successor stepped into the pulpit with no small vetulance and exultation; and began his sermon from Psalm xx. 8, "They are brought down and fallen; but we are risen, and stand upright." This person lived to be restored in 1660 , and continued vicar for eighteen years; but was so impoverished by his misfortunes, that he left the vicarage house and premises in a very abject and dilapidated state.

July 1678. Richard Byfield, who left eighty pounds by will, the interest to be applied to apprentice out poor children: but

' See Godwin, "De Præsulibus," folio, Cant. 1743, p. 239. 
this money, lent on private security, was in danger of being lost, and the bequest remained in an unsettled state for neap twenty years, till 1700 ; so that little or no advantage was derived from it. About the year 1759 it was again in the utmost danger by the failure of a borrower; but by prudent management, has since been raised to one hundred pounds stock in the three per cents. reduced. The trustees are the vicar and the renters or owners of Temple, Priory, Grange, Blackmore, and Oakhanger House, for the time being. This gentleman seemed inclined to have put the vicarial premises in a comfortable state; and began by building a solid stnne wall round the front court, and another in the lower yard, between that and the neighbouring garden; but was interrupted by death from fulfilling his laudable intentions.

April 1680, Barnabas Long became vicar.

June 1681. This living was now in such low estimation in Magdalen College, that it descended to a junior fellow, Gilbert White, M.A., who was instituted to it in the thirty-first year of his age. At his first coming he ceiled the chancel, and also floored and wainscoted the parlour and hall, which before were paved with stone, and had naked walls; he enlarged the kitchen and brewhouse, and dug a cellar and well : he also built a large uew barn in the lower yard, removed the hovels in the front court, which he laid ont in walks and borders; and entirely planned the back gardell, before a rude field with a stone-pit in the midst of it. By his will he gave and bequeathed "the sum of forty pounds to be laid out in the most necessary repairs of the church; that is, in strengthening and securing such parts as seem decaying and dangerous." With this sum two large buttresses were erected to support the east end of the south wall of the church; and the gable end wall of the west end of the south aisle was new built from the grouncl.

By his will also he gave "One hundred pounds to be laid out nn lands; the yearly rents whereof shall be employed in teaching the poor children of Selbourn parish to read and write, and say their prayers and catechism, and to sew and knit:and be under the direction of his executrix as long as she lives; and after her, under the direction of such of his children and 
their issue, as shall live in or within five miles of the said parish : and on failure of any such, then under the direction of the vicar of Selbourn for the time being; but still to the uses above-named." With this sum was purchased, of Thomas Turville, of Hawkeley, in the county of Southampton, yeoman, and Hannah his wife, two closes of freehold land, commonly called Collier's, containing, by estimation, eleven acres, lying in Hawkeley aforesaid. These closes are let at this time, 1785, on lease, at the rate of three pounds by the year.

This vicar also gave by will two hundred ponnds towards the repairs of the highways ${ }^{1}$ in the parish of Selborne. That sum was carefully and judiciously laid out in the summer of the year 1730, by his son John White, who made a solid and firm causey from Rood Green all down Honey Lane, to a farm called Oak Woods, where the sandy soil begins. This miry and gulfy lane was chosen as worthy of repair, because it leads to the forest, and thence through the Holt to the town of Farnliam in Surrey, the only market in those days for men who lad wheat to sell in this neighbourhood. This causey was so deeply bedded with stone, so properly raised above the level of the soil, and so well drained, that it has, in some degree, withstood fifty-four years of neglect and abuse; and might, with moderate attention, be rendered a solid and comfortable road. The space from lood Green to Oak Woods measures about three quarters of a mile.

In 1727 William Henry Cane, 3.D., became vicar; and, among several alterations and repairs, new built the back front of the vicarage house.

On February 1, 1740, Duncombe Bristowe, D.D., was instituted to this living. What benefactions this vicar bestowed on the parish will be best explained by the following passages from his will:- "Item, I hereby give and bequeath to the minister and churchwardens of the parish of Sclbourn, in the county of Southampton, a mahogany table, which I have ordered to be made for the celebration of the Holy Communion; and also the

1 "Such legacies were very common in former times, before any effectunl laws were made for the repairs of highways."--Sir Jonn Culuux's flausted, p. 15. 
sum of thirty pounds, in trust, to be applied in manner following; that is, ten pounds towards the charge of ereeting a gallery at the west end of the chureh; and ten pounds to be laid out for elothing, and such like necessaries, among the poor (and especially among the aneient and infirm) of the said parish; and the remaining ten pounds to be distributed in bread, at twenty shillings a week, at the discretion of John White, Esq., or any of his family who shall be resident in the said parish."

On November 12, 1758, Andrew Etty, B.D., became vicar. Among many useful repairs he new roofed the body of the viearage house; and wainscoted up to the bottom of the windows, the whole of the chancel; to the neatness and decency of which he always paid the most exact attention.

On September 25, 1784, Christopher Taylor. B.D., was indueted into the viearage of Selborne.

\section{LETTER VII.}

I suall now proceed to the Priory, which is undoubtedly the most interesting part of our history.

The Priory of Selborne was founded by Peter de la Roche, or de Rupibus, ${ }^{1}$ one of those accomplished foreigners that resorted to the court of King .Tohn, where they were usually caressed, and met with a more fayourable reeption than ought, in prudence, to have been shown by any monareh to strangers. This adventurer was a Poietevin by birth, had been bred to arms in his youth, and distinguished by knighthood. Historians all agree not to speak very favourably of this remarkable man; they allow that he was possessed of courage and fine abilities, but then they charge him with arbitrary principles, and violent conduct. By his insinuating manners he soon rose high in the favour of John; and in 1205, early in the reign of that prince, was appointed Bishop of Winchester. In 1214 he became Lord Chicf Jnsticiary of England, the first magistrate in the state, and a kind of viceroy, on

${ }^{1}$ See Godwin, "De Presulibus Anglia," folio, London, 1743, p. 217. Yot. II. 
whom depended all the civil affairs in the kingdom. After the death of John, and during the minority of his son Henry, this prelate took upou him the entire management of the realm, and was soon appointed protector of the king and kingdom.

The barons saw with indignation a stranger possessed of all the power and influence, to part of which they thought they had a claim; they therefore entered into an association against him, and determined to wrest some of that authority from Him which he had so unreasonably usurped. The bishop discerned the storm at a distance; and, prudently resolving to give way to that torrent of envy which he knew not how to withstand, withdrew quietly to the Holy Land, where he resided some time.

At this juncture a very small part of Palestine remained in the hands of the Christians : they had been by Saladin dispossessed of Jerusalem, and all the internal parts, near forty years before; and with difficulty maintained some maritime towns and garrisons; yet the busy and enterprising spirit of de Rupibus conld not be at rest; he distinguished himself by the splendlour and inagnificence of his expenses, and amused his mind by strengthening fortresses and castles, and by the improving and endowing of churches. Before his expedition to the last he had signalized himself as a founder of convents, and as a benefactor to hospitals and monasteries.

In the year 1231 he returned again to England; and the very next year, in 1232 , began to build and endow the Priory of SELnonve. As this great work followed so close upon his return, it is not improbable that it was the result of a vow made dnring his voyage; and especially as it was dedicated to the Virgin Mary. Why the bishop made choice of Selborne for the scene of his munificence can never be determined now: it can only be said that the parish was in his diocese, and lay almost midway between Winchester and Farnham, or South Waltham and Farnham; from either of which places he could without much trouble overlook his workmen, and observe what progress they made; and that the sitnation was retired, with a stream running by it, and sequestered from the world, amidst 
woods and meadows, and so far proper for the site of a religious holse. ${ }^{1}$

'The first person with whom the founder treated about the purchase of land was Jacobus de Achangre, or Ochangre, a gentleman of property who resided at that hamlet; and, as appears, at the house now called Oakhanger House. With him he agreed for a croft, or little close of land, known by the name of La Liega, or La Lyge, which was to be the immediate site of the Priory.

De Achangre also accommodated the bishop at the same instant with three more adjoining crofts, which for a time was all the footing that this institution obtained in the parish. The seller in the conveyance says "Warantizabimus, defendenus, et requietabimus contra omnes gentes;" viz. "We will warrant the thing sold against all claims from any quarter." In moderu conveyancing this would be termed a covenant for further assurance. Afterwards is added-" Pro hac autem donacione, \&c., dedit mihi pred. Episcopus sexdecem marcas argenti in Gersumam:" i.e., "the bishop gave me sixteen silver marks as a consideration for the thing purchased."

As the grant from Jac. de Achangre was without date, ${ }^{2}$ and the next is circumstanced in the same manner, we cannot say exactly what interval there was between the two purchases; but we find that Jacobus de Nortun, a neighbouring gentleman,

1 The institntion at Selborne was a priory of Black Canons of the order of St. Angustine, called also Canons Regular. Regular Canons were such as lived in a conventual manner, under one roof, had a common refectory and dormitory, and were bound by vows to observe the rules and statutes of their order : in fine, they were a kind of religious, whose diseipline was less rigid than the monks. The chief rule of these canons was that of St. Angustine, who was constituted Bishop of Hippo, A.D. 395 : but they were not brought into England till after the conquest; and seem not to have obtained the appellation of Augustine canons till some years after. Their habit was a long blitck cassock, with a white rochet over it ; and over that a black cloak and hood. The monks were always shaved: but these canons wore their hair and beards, and caps on their heads. There were of these canons, and women of the same order called Canonesses, abont one humdred aud seventyfive houses.

2 The custom of aftixing dates to deeds had not become gencral in the reign of Henry III. 
also soon sold to the Bishop of Winchester some adjoining grounds, through which our stream passes, that the priory might be accommodated with a mill, which was a common necessary appendage to every manor: he also allowed access to these lands by a road for carts and waggons.- " Jacobus de Nortun concedit Petro Winton episcopo totum cursum aque que descèndit de Molendino de Durton, usq; arl boscum Will. Mauduit, et croftam terre vocat: Edriche croft, cum extensione ejusdem et abuttamentis; ad fundandam domum religiosam de ordine Sti. Augustini. Concedit etiam viam ad carros, et caretas," \&c. This vale, down which runs the brook, is now called the Long Lithe, or Lythe. Bating the following particular expression, this grant runs mucl in the style of the former: "Dedit mihi episcopus predictus triginta quinque marcas argenti ad me ucquietandum versus $J$ udocos."-That is, "The bishop advanced me thirty-five marks of silver to pay my debts to the Jews," who were then the only lenders of money.

Finding limself still straitened for room, the founder applied to his royal master, Henry, who was graciously pleased to bestow certain lands in the manor at Selborne on the new priory of his favourite minister. These grounds had been the property of Stephen de Lucy; and, abutting upon the nurrow limits of the convent, became a very commodious and agreeable acquisition. This grant, I find, was made on March the 9th, in the eighteenth year of Henry, viz. 1234, being two years after the foundation of the monastery. The royal donor 'bestowed lis favour with a good grace, by adding to it almost every immnnity and privilege that could have been specified in the law-language of the times.-- "Quare volumus prior, \&c., liabeant totam terram, \&c., cum omnibus libertatibus in bosco et plano, in viis et semitis, pratis et pascuis; aquis et piscariis; infra burgum, et extra burgum cum soka et sica, Thol et Them, Infangenethef et Utfangenethef, et hamsocne et blodwite, et pecunia que dari solet pro mudro et forstal, et flemenestrick, et cum quietancia de omni scotto et geldo, et de omnibus auxiliis regum, vice comitum, et omn : ministralium suorum; et hidagio et exercitibus, et scutagiis, et tallagiis, et shiris et luundredis, et placitis et querelis, et warda et wardpeny, et 
opibus castellorum et pontium, et clausuris parcorum, et omni carcio et sumagio, et domor: regal : edificatione, et ommimocla reparatione, et cum omnibus aliis libertatibus." This grant was made out by Iichard, Bishop of Chichester, then Chancellor, at the town of Northampton, before the Lord Chief Justiciary, who was the founder himself.

The charter of foundation of the Priory, lated 1233, comes next in order to be considered; but being of some length, I shall not intermupt my narrative by placing it here. My copy, taken from the original, I have compared with Dugdale's copy, and find that they perfectly agree; except that in the latter the preamble and the names of the witnesses are omitted. Yet I think it proper to quote a passage from this charter-"Et ipsa domus religiosa a cujuslibet alterius domets religiosce subjcetione libera permaneat, et in omnibus absolute" to show how much Dugdale was mistaken when he inserted Selborne among the alien priories; forgetting that this disposition of the convent contradicted the grant that he had published. In the "Monasticon Anglicanum," in English, p. 119, is part of lis catalogue of alien priories, suppressed 2 Henry V. viz. 1414, where may be seen as follows:-

S.

Sele, Sussex.

SEL E B U R N.

Shirburn.

This appeared to me from the first to have been an oversight, before I had seen my authentic evidences. For priories alien, a few conventual ones excepted, were little better tlian granges to foreign abbeys; and their priors little more than bailiffs, removable at will: whereas the priory of Selborne possessed the valuable estates and manors of Selborne, Achangre, Norton, Brompden, Bassinges, Basingstoke, and Natele; and the prior challenged the right of Pillory, Thurcet, and Furcas, and every manorial privilege.

I find next a grant from Jo. de Venur, or Venuz, to the prior of Selborne-" de tota mora [a moor or bog] ubi Beme oritur 
usque ad canpum vivarii, et de prato voc. Sydenmeade cum abutt: et de cursu aque Molendini." And also a grant in reversion "unius virgate terre" [a yard land], in Achangre at the death of Richard Actedene, his sister's husband, who had no child. He was to present a pair of gloves of one penny value to the prior and canons, to be given annually by the said Richard; and to quit all elaim to the said lands in reversion, provided the prior and canons would engage annually to pay to the king, through the hands of his bailiffs of Aulton, ten shillings at four quarterly payments, "pro omnibus serviciis, consuetudinibus, exactionibus, et demandis."

This Jo. de Venur was a man of property at Cakhanger, and lived probably at the spot now called Chapel Farm. The grant bears date the seventeenth year of the reign of Henry III. [viz. 1233.]

It would be tedious to enumerate every little grant for lands or tenements that might be produeed from my vouchers. I shall therefore pase over all such for the present, and conclude this letter with a remark that must strike erery thinking person with some degree of wonder. No sooner had a monastic institution got a footing, bnt the neighbourhood began to be touched with a secret and religions awe. Every person round was desirous to promote so good a work; and either by sale, by grant, or by gift in reversion, was ambitious of appearing a benefactor. They who had not lands to spare gave roads to accommodate the infant foundation. The religious were not backward in keeping up this pious propensity, which they observed so readily influenced the breasts of men. Thus did the more opulent monasteries add honse to house, and field to field; and by degrees manor to manor: till at last "there was no place left;" but every district around became appropriated to the purposes of their founders, and every precinet was drawn into the vortex. 


\section{LETTER VIII.}

Oun forefathers in this village were no doubt as busy and bustling, and as important, as ourselves: yet have their names and transactions been forgotten from century to century, and have sunk into oblivion; nor has this happened only to the vulgar, but even to men remarkable and famous in their generation. I was led into this train of thinking by finding in my vouchers that Sir Adam Gurdon was an inhabitant of Selborne, and a man of the first rank and property in the parish. By Sir Adam Gurdon I would be understood to mean that leading and accomplished malcontent in the Mountfort faction who distinguished himself by his daring conduct in the reign of Henry III. The first that we hear of this person in my papers is, that with two others he was bailiff of Alton before the sixteenth of Henry III. viz. about 1231, and then not knighted. Who Gurdon was, and whence be eame, does not appear: yet there is reason to suspect that he was originally a mere soldier of fortune, who had raised limself by marrying women of property. The name of Gurdon does not seen to be known in the south; but there is a name so like it in an adjoining kingdom, and which belongs to two or three noble families, that it is probable this remarkable person was a North Briton; and the nore so, since the Christian name of Adam is a distinguished one to this day anong the family of the Gordons. But, be this as it may, Sir Adam Gurdon has been noticed by all the writers of English history for his bold disposition and disaffected spirit, in that be not only figured during the successful rebellion of Leicester, but kept up the war after the defeat and death of that baron, intrenching himself in the woods of Hampshire, towards the town of Farnham. After the battle of Evesham, in which Mountfort fell, in the year 1265, Gurdon might not think it safe to return to his house for fear of a surprise; but cautiously fortified himself amidst the forests and woodlands with which he was so well ảcquainted. Prince Edward, desirous of putting an end to the troubles which harl 
so long harassed the kingdom, pursued the arch-rebel into his fastnesses; attracked his camp; leaped over the intrenchments; and, singling out Gurdon, ran him down, wounded him, and took him prisoner. ${ }^{1}$

There is not perhaps in all history a more remarkable instance of command of temper and magnanimity, than this before us: that a young prince, in the moment of victory, when he had the fell adversary of the crown and royal family at his mercy, should be able to withhold his hand from that vengeance which the vanquished so well deserved. A cowardly disposition would have been blinded by resentment: but this gallant heir-apparent saw at once a method of converting a nnost desperate foe into a lasting friend. He raised the fallen veteran from the ground, he pardoned him, he admitted him into his confidence, and introduced him to the queen, then lying at Guildford, that very evening. ${ }^{2}$ This unmerited and unexpected lenity melted the heart of the rugged Gurdon at once; he became in an instant a loyal and useful subject, trusted and einployed in matters of moment by Edward when king, and confided in till the day of his death.

\section{LETTER IX.}

IT has been hinted in a former letter that Sir Adam Gurdon had availed himself by marrying women of property. By my evidences it appears that he had three wives, and probably in the following order: Constantia, Ameria, and Agnes. The first of these ladies, who was the companion of his middle life, scems to have been a person of considerable fortune, which she inherited from Thomas Makerel, a gentleman of Selborne, who was either her father or uncle. The second, Ameria, calls herself the quondam wife of Sir Adam, "quæ fui uxor," \&c., and talks of her sons under age. Now Gurdon had no son: and beside Agnes in another document says, "Ego Agnes, quondam uxor Domini Adx Gurdon, in pura tigea viduitate mea:" but Gurdon could not leave two widows; and therefore it seems probable that he harl

1 M. Paris, p. 675, and Triveti Annale. 
been divorced from Amerin, who afterwards married, and had sons. By Agnes Sir Adam had a daughter Johanna, who was his heiress, to whom Agnes in her lifetime surrendered part of her jointure :-he had also a bastard son.

Sir Adam seems to have inhabited the house now called Temple, lying about two miles east of the church, which had been the property of Thomas Makerel.

In the year 1262 lie petitioned the prior of Selborne in his own name, and that of his wife Constantia only, for leave to build bim an oratory in his manor house, "in curia sun." Licenses of this sort were frequently obtained by men of fortune and rank from the bishop of the diocese, the archbishop, and sometimes, as I have seen instances, from the pope; not only for convenience' sake, and on account of distance, and the badness of the roads, but as a matter of state and distinction. Why the owner should apply to the prior, in preference to the bishop of the diocese, and how the former becaine competent to such a grant, I cannot say; but that the priors of Selborne did take that privilege is plain, because some years afterward, in 1280, Prior Richard granted to Henry Waterford and his wife Nichola a license to build an oratory in their courthouse, "curin sua de Waterford," in which they might celebrate divine service, saving the rights of the mother cluurch of Basynges. Yet all the while the prior of Selborne grants with such reserve and caution, as if in doubt of his power, and leaves Gurdon and his lady answerable in future to the bishop, or his ordinary, or to the vicar for the time being, in case they should infringe the rights of the mother claurcl of Selborne.

The manor house called Temple is at present a single building, running in length from south to north, and has been occupied as a common farmhouse from time immemorial. The south end is modern, and consists of a brewhouse, and then a kitchen. The middle part is a hall twenty-seven feet in length, and nineteen feet in breadth; and has been formerly open to the top; but there is now a floor above it, and also a chimney in the western wall. The roofing consists of strong massive rafter-work ornamented with carved roses. I have often looked for the lamb and flag, the arms of the Knights Templars, without VOL. II. 
success; but in one corner found a fox with a goose on his back, so coarsely executed, that it required some attention to make ont the device.

Beyond the hall to the north is a small parlour with a vast heavy stone chimney-piece; and, at the end of all, the chapel or oratory, whose massive thick walls and narrow windows at once bespeak great antiquity. This room is only sixteen feet by sixteen feet eight inches; and full seventeen feet nine inches in height. The ceiling is formed of vast joists, placed only five or six inches apart. Modern delicacy would not much approve of such a place of worship: for it has at present much more the appearance of a dungeon than of a room fit for the reception of people of condition. The field on which this oratory abuts is still called Chapel Field. The situation of this house is very particular, for it stands upon the immediate verge of a steep abrupt hill.

Not many years since, this place was used for a hop-kiln, and was divided into two stories by a loft, part of which remains at present, and makes it convenient for peat and turf, with which it is stowed.

\section{LETTER $X$}

Tre Priory at times was much obliged to Gurdon and his family. As Sir Adam began to advance in years he found his mind influenced by the prevailing opinion of the reasonableness and efficacy of prayers for the dead; and, therefore, in conjunction with his wife Constantia, in the year 1271, granted to the prior and convent of Selborne all his right and claim to a certain place, placec, called La Pleystow, in the village aforesaid, "in liberam, puram, et perpetuam elemosinam." This Pleystow, ${ }^{1}$ locus ludorum, or play-place, is a level area near the church of about forty-four yards by thirty-six, and is known now by the name of the Plestor. ${ }^{2}$

1 In Suxon ylıgcstow, or juligstoto ; viz. Plegestow, or Plegstow.

2 At this juncture probably the vast oak, mentioned p. 5, was planted by the prior, as an ornament to his new acquired market-place. According to 
It continues still, as it was in old times, to be the scene of recreation for the youths and children of the neighbourhood; and impresses an idea on the mind that this village, even in Saxon times, could not be the most abject of places, when the inhabitants thought proper to assign so spacious a spot for the sports and amusements of its young people. ${ }^{1}$

As soon as the prior became possessed of this piece of ground, he procured a charter for a market ${ }^{2}$ from King Henry III. and began to erect houses and stalls, "seldas," around it. From this period Selborne becaune a market town: but how long it enjoyed that privilege does not appear. At the same time Gurdon reserved to himself and his heirs a way through the said Plestor to a tenenent and some crofts at the upper end, abutting on the south corner of the churchyard. This was, in old days, the manorial house of the street manor, though now a poor cottage; and is known at present by the modern name of Elliot's. Sir Adam also did, for the health of his own soul, and that of his wife Constantia, their predecessors and successors, grant to the prior and canons quiet possession of all the tenements and gardens, "curtillagia," which they had built and laid ont on the lands in Selborne, on which he and his vassals, "homines," had undoubted right of common: and inoreover did grant to the convent the full privilege of that right of common ; and empowered the religious to build tenements and make gardens along the king's highway in the village of Selborne.

From circumstances put together it appears that the above

this supposition the oak was aged four hundred and thirty-two years when blown down.

1 For more circumstances respecting the Plestor, seo Letter II. to Mr. Pennant.

2 Bishop Tunner, in his "Notitia Monastica," has made a mistake respecting the market and fair at Selborne: for in his references to Dodsworth, cart. 54 Hen. III. 11. 3, he says, "De mercatu, et feria de Seleburn." But this reference is wrong; for instead of Seleburn, it proves that the place there meant was Lekeborne, or Legcborn, in the county of Lincoln. This error was copied from the index of the Cat. MSS. Angl. It does not appear that there ever was a chartered fiir at Selborne.--For several particulars respecting the present fair at Selborne see Letter XXVI, of these Antiquities. 
were the first grants ubtained by the Priory in the village of Selborne, after it had subsisted about thirty-nine years: moreover, they explain the nature of the mixed manor still remaining in and about the village, where one field or tenement shall belong to Magdalen College in the University of Oxford, and the next to Norton Powlet, Esq., of Rotherficld House; and so down the whole street. The case was, that the whole was once the property of Gurdon, till he made his grants to the convent; since which some belongs to the successors of Gurdon in the nnanor, and some to the college; and this is the occasion of the strange jumble of property. It is remarkable that the tenement and crofts which Sil Adam reserved at the time of granting the Plestor should still remain a part of the Gurdon manor, though so desirable an addition to the vicarnge that is not as yet possessed of one inch of glebe at home: but of late, viz. in January, 1785, Magdalen College purchased that little estate, which is life-holding, in reversion, for the generous purpose of bestowing it, and its lands, being twelve acres (three of which abut on the churchyard and vicarage garden) as an improveraent hereafter to the living, and an eligible advantage to future incumbents.

The year after Gurdon had bestowed the Plestor on the Priory, viz. in 1272, Henry III. King of England died, and was succeeded by his son Edward. This magnanimous prince continued his regard for Sir Adam, whom he esteemed as a brave man, and made him warden, "custos," of the forest of Wolmer. ${ }^{1}$ Though little emolument might hang to the appoint-

1 Since the letters respecting Wolmer Forest and Ayles Holt, from p. 14 to p. 27, were printed, the anthor has been favoured with the following extracts :-

In the "Act of Resumption, 1 Hen. VII." it was provided, that it be not prejudicial to "Harry at Lode, ranger of our forest of Wolmere, to him by oure letters patents before tyme gevyn." - Rolls of Parl. vol. vi. p. 370 .

In the 11 Hen. VII. 1495.- "Warlham [Wardleham] and the offiee of forest [forester] of Wolmere" were held by Edmund, Duke of Suffolk. Rolls, íb. 474.

Act of general pardon, 14 Heı. VIII. 1523, not to extend to " Rich. Bp. of Wynton [Bishop Fox] for any seizure or forfeiture of liberties, \&c. within the forest of Wolmer, Alysholt, and Newe Forest; nor to any person for waste, 
ment, yet are there reasons why it might be highly acceptable; and, in a few reigns after, it was given to princes of the blood. ${ }^{\text {. }}$ In old days gentry resided more at home on their estates, and having fewer resources of elegant in-door amusement, spent most of their leisure hours in the field and the pleasures of the chase. A large domain, therefore, at little more than a mile distance, and well stocked with game, must liave been a very eligible acquisition, affording him influence as well as entertainment; and especially as the manorial house of Temple, by its exalted situation, could command a view of near two-thirds of the forest.

That Gurdon, who hacl lived some years the life of an outlaw and at the head of an army of insurgents, was, for a considerable time, in high rebellion against his sovereign, should have been

\&c. within the manor of Wardlam, or parish of Wardlam [Wardleham;] nor to abusing, \&c. of any office or fee, within the said forests of Wolmer or Alysholt, or the said park of Wardlam."-County Suth't._-Rolls prefixed to first vol. of Journals of the Lords, p. xciii. b.

To these may be added some other particulars, taken from a book lately published, entitled "An Account of all the Manors, Messuages, Lands, \&c., in the Difierent Counties of England and Wales, held by Lease from the Crown; as contrined in the Report of the Commissioners appointed to inquire into the State and Condition of the Royal Forests," \&c.-London, 1787. "Southampton."

P. 64. "A fee-farm rent of 34l.2s. 1Id. out of the manors of East and West Wardleham; and also the office of lieutenant or keeper of the forest or chase of Aliceliolt and Wolmer, with all offices, fees, commodities, and privileges thereto belonging.

"Names of lessees, William, Earl of Dartmouth aud others (in trust).

"Date of the last lease, March 23, 1780 ; granted for such term as would fill up the subsisting term to thirty-one years.

"Expiration, March 23, 1811."

"Appendix, No. III."

"Southampton."

"Hundreds -Selborne and Fincldeane."

"Honours and manors," \&c.

"Aliceholt Forest, three parks there.

"Bensted and Kingsley; a petition of the parishioners concerning the threo parks in Aliceholt Forest."

William, first Earl of Dartmouth, and paternal grandfather to the present Lord Stawel, was a lessee of the forests of Aliceholt and Wolmer before Brigadier-Gencral Emanuel Scroope Howe.

1 See Letter II. of these Antiquities. 
guilty of some outrages, and should have eommitted solve depre(lations, is by no means matter of wonder. Accordingly we find a distringas against him, ordering him to restore to the Bishop of Winehester some of the temporalities of that see, which he had taken by violenee and detained; viz. some lands in Hocheleye, and a mill. By a breve, or writ, from the king he is also enjoined to readmit the Bishop of Winchester, and his tenants of the parish and town of Farnham, to pasture their horses, and other larger cattle, "averia," in the Forest of Wolner, as had been the usage from time immemorial. This writ is dated in the tenth year of the reign of Edward, viz. 1282 .

All the king's writs directed to Gurdon are addressed in the following manner : "Edwardus, Dei gratia, \&c., dilecto et fideli suo Ade Gurdon salutem;" and again, "Custodi foreste sue de Wolvemere."

In the year 1293 a quarrel between the erews of an English and a Norman ship, about some trifle, brought on by degrees such serious consequenees, that in 1295 a war broke out between the two nations. The French king, Philip the Hardy, gained some advantages in Gascony; and, not content with those, threatened England with an invasion, and, by a sudden attempt, took and burnt Dover.

Upon this emergeney Edward sent a writ to Gurdon, ordering him and four others to enlist three thousand soldiers in the counties of Surrey, Dorset, and Wiltshire, able-bodied men, "tam sagittare quam balistare potentes:" and to see that they were marched, by the feast of All Saints, to Winehelsea, there to be embarked aboard the king's transports.

The oceasion of this armament appears also from a sunmons to the Bishop of Winchester to parliament, part of which I shall transeribe on account of the insolent menace whieh is said therein to have been denounced against the English language:"qualiter rex Franciæ de terra nostra Gascon nos fraudulenter et eautelose decepit, ean nobis nequiter detenendo ... vero predietis fraude et nequilia non contentus, ad expugnationem

1 Hocheleye, now spelt Hawkley, is in the hundred of Selborne, and has a mill at this day. 
regni nostri classe maxima et bellatorum copiosa multitudine congregatis, cum quibus regnum nostrum et regni ejusdem incolas hostiliter jam invasurus, linguan Anglicam, si concepte iniquitatis proposito detestabili potestas correspondeat, quod Deus avertat, omnino de terra delere proponit." Dated 30th September, in the year of King Edward's reign xxiii. ${ }^{1}$

The above are the last traces that I can discover of Gurdon's appearing and acting in public. The first notice that my evidences give of him is, that, in 1232, being the sixteenth of Henry III. he was the king's bailiff, with others, for the town of Alton. Now, from 1232 to 1295 is a space of sixty-three years; a long period for one man to be employed in active life : Should any one doubt whether all these particulars can relate to one and the same person, I should wish him to attend to the following reasons why they might. In the first place, the documents from the Priory mention but one Sir Adam Gurdon, who had no son lawfully begotten: and in the next, we are to recollect that he must have probably been a man of uneornmon vigour both of mind and body; since no one, unsupported by such accomplishments, could have engaged in such adventures, or could have borne up against the difficulties which he sometimes must have encountered: and, moreover, we have modern instances of persons that have maintained their abilities for near that period.

Were we to suppose Gurdon to be only twenty years of age in 1232 , in 1295 he would be eighty-three; after which advanced period it could not be expected that he should live long. From the silence, therefore, of my evidences it seems probable that this extraordinary person finished his life in peace, not long after, at his mansion of Temple. Gurdon's seal had for its device -a man with a helmet on his head, drawing a cross-bow; the legend, "Sigilhm Ade de Gurdon;" his arms were, "Goulis, iii floures argent issant de testes de leopards." 2

If the stout and unsubmitting spirit of Gurdon could be so

Reg. Wynton, Stratford, but query Stratford; for Stratford was not Bishop of Winton till 1323, near thirty years afterwards.

2 From the collection of Thomas Martin, Esq., in the "Antiquarian Repertory," p. 109, No. XXXI. 
mucls influenced by the belief and superstition of the times, much more might the hearts of his ladies and daughter. And accordingly we find that Ameria, by the consent and advice of her sons, though said to be all under age, makes a grant for ever of some lands down by the stream at Durton; and also of her right of the common of Durton itself. ${ }^{1}$ Johanna, the daughter and heiress of Sir Adam, was married, I find, to Richard Achard; she also grants to the prior and convent lands and tenements in the village of Selborne, which her father obtained from Thomas Makerel ; and also her goods and chattels in Selborne for the consideration of two hundred pounds sterling. This last business was transacted in the first year of Edward II. viz. 1307. It has been observed before that Gurdon had a natural son: this person was called by the name of John Dastard, alias Wastard, but more probably Bastard; since bastardy in those days was not deemed any disgrace, though dastardy was esteemed the greatest. He was married to Gunnorie Duncun; and had a tenement and some land granted him in Selborne by his sister Johanna.

\section{LETTER XI.}

The Knights Teinplars, ${ }^{2}$ who have been mentioned in a former letter, had considerable property in Selborne; and also a pre-. ceptory at Sudington; now called Southington, a hamlet lying

1 Durton, now called Dorton, is still a conmon for the copyholders of Selborne manor.

2 The Military Orders of the Religious:-

The Knights Hospitalars of St. John of Jerusalem, afterwards called Knights of Rhodes, now of Malta, came into England about the year 1100, 1 Hen. I.

The Knights Templars came into England pretty early in Stephen's reign, which commenced 1135 . The order was dissolved in 1312, and their estates given by act of Parliament to the Hospitalars in 1323 (all in Edw. II.) though many of their estates were never actually enjoyed by the said Hospitalars. - Vid. Tanner, p. xxiv. x.

The commandries of the Hospitalars, and preceptories of Templars, were each subordinate to the principal house of their respective religion in Londou. 
one mile to the east of the village. Bishop Tanner mentions only two such honses of the Templars in all the comnty of Sonthampton, viz. Todesfield, founded by Henry de Blois, Bishop of Winchester, and South Badeisley, a preceptory of the Knights Templars, and afterwards of St. John of Jerusalem, valued at one hundred and eighteen pounds sixteen shillings and sevenpence per annum. Here then was a preceptory unnoticed by antiquaries, between the village and Temple. Whatever the

Although these are the different denominations which Tanner at p. xxviii. assigns to the cells of these different orders, yet throughout the work very frequent instances occur of preceptories attributed to the Hospitalars; and if in some passages of Notitia Monast. comnundries are attribnted to the Templars, it is only where the place afterwards became the property of the Hospitalars, and so is there indifferently styled preceptory or commandry; see $\mathrm{p} .243,263,276,577,678$. But, to account for the first observed inaccnracy, it is probable the preceptories of the Templars, when given to the Hospitalars, were still vulgarly, however, called by their old name of preceptories: whereas in propriety the socicties of the Hospitalars were indeel (as las been said) commandries. And such deviation from the strictness of expression in this case might occasion these societies of Hospitalars also to be indifferently called preceptories, which had originally been vested in them, having never belonged to the Templars at all.-See in Archer, p. 609. Tanner, p. 30(1, col. 1,720 , note $e$.

It is observable that the very statute for the dissolution of the Hospitalars loolds the same langnage; for there in the enuneration of particulars, occur "commandries, preceptories." Codex, p. 1190. Now this intercomnunity of names, and that in an act of parliament too, made some of our ablest untiquaries look upon a preceptory and commandry us strictly synonymous; accordingly we find Camden, in his "Britannia," explaining preceptoria in the text by a commandry in the inargin, p. 356, 510.-J. L.

Conmandry, a manor or chief messuage with lands, \&c. belonging to the priory of St. John of Jerusalem; and he who had the government of sueh house was called the commander, who conld not dispose of it hut to the use of the priory, only taking thence his own sustenance, according to bis degree, who was usually a brother of the same priory.-Cowell. He adds (confounding these with preceptories) they are in many places termed Temples, as Temple Bruere in Lincolnshire, \&e. Preeptories were possessed by the more eminent sort of Templirs, whom the chief master created and eslled Freceptores Templi. Cowell, who refers to Stephen's De Jnrisd. lib. 4, c. 10, nnm. 27.

Placita de juratis et assis coram Salom. de Roff et socis suis justic. Itiner, apnd Wynton, \&c. anno regni R. Edwardi fil. Reg. Hen. octavo. - "et Magr. Milicie Templi in Angl. bt emendassē panis, \& suis [corevisire] in Sodington, \& nescint $q^{\circ}$. war. et-et magist. Mlilicie Templi nön vën iō distr.-Chapter House, Westminster.

VOL. 11 .

c c 
edifice of the preceptory might have been, it has long since been dilapidated; and the whole hamlet contains now only olle mean farmhouse, though there were two in the meniory of man.

It has been usual for the religions of different orders to fall into great dissensions, and especially when they were near neighbours. Instances of this sort we have heard of between the monks of Canterbury; and again between the old abbey of St. Swythun, and the comparativcly new minster of Hyde in the city of Winchester. ${ }^{1}$ These feuds arose probably from different orders being crowded within the narrow limits of a city, or garrison-town, where every inch of ground was precious, and an object of contention. But with us, as far as my evidences extend, and while Robert Saunford was master, ${ }^{2}$ and Richard Carpenter was preceptor, the Templars and the Priors lived in an intercourse of mutual good offices.

My papers mention three transactions, the exact time of

1 Notitia Monastica, p. 155.

"Winchester, Newminster. King Alfred founded bere first only a house and chapel for the learned monk Grimbald, whem he had brought out of Flanders: but afterwards projected, and by his will ordered, a noble church or religious house to be built in the cemetery on the verth side of the old minster or cathedral ; and designed that Grimbald should preside over it. This was begun A.D. 901, and finished to the honour of the Holy Trinity, Virgin Mary, and St. Peter, by his son King Edward, who placed therein secnlar canons : but A.D. 963, they were expelled, and an abbot and monks put in possession by Bishop Ethelwold.

"Now the churches and habitations of these two societies being so very near together, the differences which were occasioned by their singing, bells, and other matters, arose to so great a height, that the religions of the new monastery thought fit, about A.D. 1119, to remove to a better and more quiet situation withont the walls, on the north part of the city called HyDE, where King Henry I. at the instance of Will. Gifford, Bishop of Winton, founded a stately abbey for them. St. Peter was generally accounted patron; though it is sometimes called the nonastery of St. Grimbald, and sometimes of St. Barnabas," \&c.

Note. A few years since a county bridewell, or house of correction, has been built on the immediate site of Hyde Abbey. In digging up the old fonndations the workmen found the head of a crosier in good preservation.

Robert Saunforde was master of the Templo in 1241; Guido de Foresta was the next in 1292. The former is fifth in a list of the masters in a MS. Bib. Cotton. Nero. E. VI. 
which eannot be ascertained, because they fell out before dates were usually inserted; though probably they happened about the middle of the thirteenth century; not long after Saunford became master. The first of these is that the Templars shall pay to the priory of Selborne, annually, the sum of ten shillings at two half-yearly payments from their chamber, "camera," at Sudington, "per manum preceptoris, vel ballivi nostri, qui pro tempore fuerit ibidem," till they can provide the prior and canons with an equivalent in lands or rents within four or five miles of the said convent. It is also further agreed that, if the Templars shall be in arrears for one year, that then the prior shall be empowered to distrain upon their live stock in Bradeseth. The next matter was a grant from Robert de Saunford to the Priory for ever, of a good and sufficient road, "chcminum," capable of admitting carriages, and proper for the drift of their larger cattle, from the way which extends from Sudington towards Blakemere, on to the lands which the convent possesses in Bradeseth.

The third transaction (though for want of dates we cannot say whicl liappened first and which last) was a grant from Robert Samford to the Priory of a tenement and its appurtenances in the village of Selborne, given to the Templars by Americus de Vasci.. This property, by the manner of describing it,- " totum tenementum cum omnibus pertinentiis suis, scilicet in terris, \& hominibus, in pratis \& pascuis, \& nemoribus," \&c., seems to have been no inconsiderable purchase, and was sold for two liundred marks sterling, to be applied for the buying of more land for the support of the holy war.

Prior John is mentioned as the person to whom Vasci's land is eonveyed. But in Willis's list there is no Prior John till 1339 several years after the dissolution of the order of the Templars in 1312 ; so that unless Willis is wrong, and has omitted a Prior Joln since 1262 (that being the date of his first prior), these transactions must have fallen out before that ilate.

\footnotetext{
1 Americus de Vasci, by his name, must have been an Italian, and had bcen probably a soldier of fortune, and one of Gurdon's captains. Americus Vespucio, the person who gave naine to the new world, was a Florentine.
} 
I find not the least traces of any eoneerns between Gurdon and the Knights Templars; but probably after liis death his daughter Johanna might have, and might bestow, Temple on that order in support of the Holy Land: and, moreover, she seems to lave been moving from Selborne when she sold her goods and chattels to the Priory, as mentioned above.

Temple no doubt did belong to the knights, as may be asserted, not only from its name, but also from another corroborating circunstance of its being still a manor tithe-free; "for, by virtue of their order," says Dr. Blackstone, "the lands of the Knights Templars were privileged by the pope with a discharge from tithes."

Antiquaries have been much puzzled about the terms preceptores and preceptorium, not being able to determine what officer or edifice was meant. But perhaps all the while the passage quoted above from one of my papers "per manum meccptoris vel ballivi nostri, qui pro tempore fuerit ibidem," may help to explain the diffieulty. For if it be allowed here that prceeptor and ballivus are synonymous words, then the brotber who took on hin that offiee resided in the house of the Templars at Sudington, a preceptory; where he was their meccptor, superintended their affairs, received their money; and, as in the instance there mentioned, paid from their ehamber, "comera," as direeted: so that, according to this explanation, a prcceptor was no other than a steward, and a preceptorium was his residenee. I am well aware that, aceording to striet Latin, the $v e l$ should have been seu or sivc, and the order of the words "preceptoris nostri, vel ballivi, qui "-et "ibidem" should have been $i b i$; $i b i d c m$ necessarily having reference to two or more persons: but it will hardly be thought fair to apply the nieeties of classie rules to the Latinity of the thirtcenth eentury, the writers of which seem to have aimed at nothing farther than to render themselves intelligible.

There is another remark that we have made, which, I think, corroborates what has been advanced; and that is, that Riehard Carpenter, preeeptor of Sudington, at the time of the transactions between the Templars and Selborne Priory, did always sign last as a witness in the three deeds: he calls himself frater, it is true, 
among many other brothers, but subscribes with a kind of difference, as if, for the time being, his office rendered him an inferior in the community. ${ }^{1}$

\section{LETTER XII.}

True ladies and daughters of Sir Adam Gurdon were not the only benefactresses to the Priory of Selborne; for, in the year 1281, Ela Longspee obtained masses to be performed for her soul's health; and the prior entered into an engagement that one of the convent should every day say a special mass for ever for the said benefactress, whether living or dead. She also engaged within five years to pay to the said convent one hundred marks of silver for the support of a chantry and chantrychaplain, who should perform his masses daily in the parish church of Selborne. ${ }^{2}$ In the east end of the south aisle there there are two sharp-pointed Gothic uiches; one of these probably was the place under which these masses were performed; and there is the more reason to suppose as inuch, because till

1 In two or three ancient records relating to St. Oswald's Hospital in the city of Worcester, printed by Dr. Nash, p. 227 and 228, of his Collections for the History of Worcestershire, the words precptorium and preceptoria signify the mastership of the said hospital: "ad preceptorium sive magisterium presentavit-preceptorii sive magisterii patronus. Vacavit dicta preceptoria seu magisterium-ad preceptoriam et regimen dicti hospitalis-Te preceptorem sive magistrum prefecinus."

Where prcceptoriom denotes a building or apartment it may probaluly mean the master's lodgings, or at least the preceptor's apartment, whatsoever may have been the office or employment of the said preceptor.

A preceptor is mentioned in Thoresby's "Ducatus Leodinensis," or History of Leeds, p. 225, and a decd witnessed by the preceptor and chaplain before dates were inserted.-Dn Fresne's Supplement: "Preceptorice, proedia preceptoribus assignata."-Cowell, in his Law Dictionary, enumerates sixteen preceptoric, or preceptories, in England ; but Sudington is not among them.It is remarkable that Gurtclerus, in his "Historia Templariorum Amstel." 1691, never once snentions the words preccptor or preceptorium.

2 A chantry was a chapel joined to some cathedral or parish church, and endowed with annual revenues for the maintenance of one or noro priests to sing mass daily for the soul of the founder, and others. 
within these thirty years, this place was fenced off with Gothic wooden railing, and was known by the name of the south chancel. ${ }^{1}$

The solicitude expressed by the donor plainly shows her piety and firm persuasion of the efficacy of prayers for the dead; for she seems to have made every provision for the payment of the sum stipulated within the appointed time; and to have felt much anxiety lest her death, or the neglect of her executors or assigns, might frustrate her intentions. - " Et si coniingat me in solucione predicte pecunie annis predictis in parte aut in toto deficere, quod absit; concedo et obligo pro me et assignatis meis, quod Vice-Comes ... Oxon at .... . qui pro tempore fuerint, per omnes terras et tenementa, et omnia bona mea mobilia et immobilia ubicunque in balliva sua fuerint inventa ad solucionem predictam faciendam possent nos compellere." And again-“Et si contingat dictos religiosos labores seu expensas facere circa predictam pecuniam, seu circa partem dicte pecunie; volo quod dictorum religiosorum impense et labores levantur ita quod predicto priori vel uni canonicorum suolum superhiis simplici verbo credatur sine alterius honere probacionis; et quod utrique predictorum virorum in unam marcam argenti pro cujuslibet distrincione super me facienda tenear.-Dat. apud Wareborn die sabati proxima ante festum St. Marci evangeliste, anno regni regis Edwardi tertio decimo." 2

But the reader perhaps would wish to be better informed respecting this benefactress, of whom as yet he lias heard no particulars.

The Ela Longspee therefore above mentioned was a lady of high birth and rank, and became cuuntess to Thomas de Newburgh, the sixth Earl of Warwick: she was the second daughter

1 For what is said more respecting this chantry see Letter III. of these Antiquities.-Mention is made of a Nicholas Langrish, capellanus de Selborne, in the time of Henry VIII. Was he chantry-chaplain to Ela Longspee, whose masses were probably continued to the time of the Reformation? More will be said of this person hereafter.

${ }^{2}$ Ancient deeds are often dated on a Sunday, having been executed in churches and churchyards for the sake of notoriety, and for the conveniency of procuring several witnesses to attest. 
of the famous Ela Longspee, Countess of Salisbury, by William Longspee, natural son of King Henry II. by Rosamond.

Our lady, following the steps of her illustrious mother," "wis a great benefactress to the University of Oxford, to the canons of Oseney, the nuns of Godstow, and other religious houses in Oxfordshire. She died very aged in the year $1300,{ }^{2}$ and was buried before the high altar in the abbey church of Oseney, at the liead of the tomb of Heury D'Oily, under a flat marble, on which was inlaid her portraiture, in the liabit of a vowess, engraved on a copper-plate."-EDMonson's History and Genealogical Account of the Grevilles, p. 23.

\section{LETTER XIII.}

THE reader is here presented with the titles of five forms respecting the choosing of a prior: No. 108. "Charta petens licentiam elegendi prelatum a Domino episcopo Wintoniensi :" -_Forma licentie concesse:"-_"Forma clecreti post electionen conficiendi:"-108. "Modus procendendi ad electionem per forman scrutinii :"--et "Forma ricte presentandi electum." Such evidences are rare and curious, and throw great light upon the general monastico-ecclesiastical history of this kingdom, not yet sufficiently understood.

In the year 1324 there was an election for a prior at Selborne; when some difficulties occurring, and a devolution taking place, application was made to Stratford, who was Bishop of Winchester at that time, and of course the visitor and patron of the convent at the spot above mentioned. ${ }^{3}$

1 Ela Longspee, Countess of Salisbury, in 1232, founded a monastery at Lacock, in the county of Wilts, and also another at Hendon, in the county of Somerset, in her widowlood, to the honour of the Blessed Virgin and St. Bernard. -CAMDEN.

2 Thus she survived the foundation of her chantry at Selborne fifteen years. About this lady and her mother consult Dngdale's Baronage, i. 72, 175, 177. -Dugdale's Warwickshire, i. 383.-Leland's Itin. ii. 45.

${ }^{3}$ Stratford was Bishop of Winchester from 1323 to 1333 , when he was translated to Canterbury. 
AN EXTRACT FROM REG. STRATFORD. WINTON.

P. 4. "Commissio facta sub-priori de Selebourne" by the bishop enjoining him to preserve the discipline of the order in the convent during the vacancy made by the late death of the prior, ("super pastoris solatio destituta,") dated 4, th. kal. Maii. ann. $2^{\text {do }}$ sc. of his consecration. [sc. 1324.]

P. 6. "Custodia Prioratus de Selebourne vacantis," committed by the bishop to Nicholas de la . . ., a layman, it belonging to the bishop "ratione vacationis ejusdem," in July, 1224, ibid. "negotium electionis de Selebourne. Acta coram Johanue Episcopo, \&c. 1324 in negotio electionis de fratre Waltero de Insula concanonico prioratus de Selebourue," lately elected by the subprior and convent, by way of scrutiny : that it appeared to the bishop, by certificate from the Dean of Alton, that solemn citation and proclamation had been made in the church of the convent where the election was held, that any who opposed the said election or elected should appear. Some difficulties were started, which the bishop overruled, and confirmed the election, and admitted the new prior sub hac forma:-

"In Dei nomine Amen. Ego Johannes permissione divina, \&c. te Walterum de Insula ecclesie de Selebourne nostre dioceseos nostrique patronatus vacantis, canonicum et cautorem, virum utique providum, et discretum, literarum scientia preditum, vita moribus et conversatione merito commendatum, in ordine sacerdotali et etate legitima constitutum, de legitimo matrimonio procreatum, in ordine et religione Sancti Augustini de Selebourne expresse professum, in spiritualibus et temporalibus circumspectum, jure nobis hac vice devoluto in hac parte, in dicte ecclesie de Selebourne perfectum priorem; curam et administrationem ejusdem tibi in spiritualibus et temporalibus committentes. Dat. apud Selebourne XIII kalend. Augusti anno supradicto."

There follows an order to the sub-prior and convent pro obeclientia :

A mandate to Nicholas above-named to release the Priory to the new prior:

A maudate for the induction of the new prior. 


\section{LETTER XIV.}

"Is the year 1373 Wykeham, Bishop of Winchester, held a visitation of his whole diocese; not only of the secular clergy through the several deaneries, but also of the monasteries, and religious houses of all sorts, which he visited in person. The next year he sent his commissioners with power to correct and reform the several irregularities and abuses which he had discovered in the course of his visitation.

"Some years afterward, the bishop having visited three several times all the religious honses throughout his diocese, and being well informed of the state and condition of each, and of the particular abuses which required correction and reformation, besides the orders which he had already given, and the remedies wlich he had occasionally applied by his commissioners, now issued his injunctions to each of them. They were accommodated to their several exigencies, and intended to correct the abuses introduced, and to recall them all to a strict observation of the rules of their respective orders. Many of these injunctions are still extant, and are evident monuments of the care and attention with which he discharged this part of his episcopal duty." 1

Some of these injunctions I shall here produce; and they are such as will not fail, I think, to give satisfaction to the antiquary, both as never having been published before, and as they are a curious picture of monastic irregularities at that time.

The documents that I allude to are coutained in the Notabilis Visitatio de Selebourne, held at the Priory of that place, by Wykeham in person, in the year 1387.

This evidence, in the original, is written on two skins of parchment; the one large, and the other smaller, and consists of a preamble, thirty-six items, and a conclusion, which altogether evince the patient investigation of the visitor, for which he had always been so remarkable in all matters of moment,

VOL. II.

'See Lowth's "Life of Wykeham."

D D 
and how much he had at heart the regularity of those institutions, of whose efficacy in their prayers for the dead he was so firmly persuaded. As the bishop was so much in earnest, we may be assured that he had nothing in view but to correct and reform what he found amiss; and was under no bias to blacken, or misrepresent, as the commissioners of Thomas Lord Cromwell seem in part to have done at the time of the Reformation. ${ }^{1}$ We m.ry therefore with reason suppose that the bishop gives us an exact delineation of the morals and manners of the canons of Selborne at that juncture; and that what he found they had omitted he enjoins them; and for what they had done amiss, and contrary to their rules and statutes, he reproves them; and threatens. them with punishment suitable to their irregularities.

This visitatio is of considerable length, and cannot be introcluced into the body of this work; we shall therefore take some notice, and make some remarks, on the most singular items as they occur.

In the preamble the visitor says- " Considering the charge lying upon us, that your blood may not be required at our hands, we came dowll to visit your Priory, as our office required: and every time we repeated our visitation we found something still not only contrary to regular rules, but also repugnant to religion and good reputation."

In the first article after the preamble- " he commands them on their obedience, and on pain of the greater excommunication, to see that the canonical hours by night and by day be sung in their choir, and the masses of the Blessed Mary, and other accustomed masses, be celebrated at the proper hours with clevotion, and at moderate pauses; and that it be not allowed to any to absent themselves from the hours and masses, or to withdraw before they are finished."

Item 2d. He enjoins them to observe that silence to which they are so strictly bound by the rule of St. Augustine at stated times, and wholly to abstain from frivolous conversation.

Item 4th. "Not to permit such frequent passing of secular

1 Letters of this sort from Dr. Layton to Thomas Lord Cromwell are still extant. 
people of both sexes through their convent, as if a thoroughfare, from whence many disorders may and have arisen."

Item 5th. "To take eare that the doors of their church and Priory be so attended that no suspected and disorderly females, 'suspectx et alix inhonestre,' pass through their choir and cloister in the dark;" and to see that the doors of their church between the nave and the choir, and the gates of their cloister opening into the fields, be constantly keep shut until their first choir-service is over in the morning, at dinner time, and when they meet at their evening collation. ${ }^{1}$

Item 6 th mentions that several of the eanons are found to be very ignorant and illiterate, and enjoins the prior to see that they be better instrueted by a proper master.

Item 8th. The canons are here accused of refusing to accept of their statutable clothing year by year, and of dennanding a certain specified sum of money, as if it were their annual rent and due. This the bishop forbids, and orders that the canons shall be clothed out of the revenue of the Priory, and the old garments be laid by in a ehamber and given to the poor, accord. ing to the rule of St. Augustine.

In Item 9 th is a complaint that some of the canons are given to wander out of the precincts of the convent without leave; and that others ride to their manors and farms, under pretence of inspecting the concerns of the society, when they please, and stay as long as they please. But they are enjoined never to stir either about their own private concerns or the business of the convent without leave from the prior: and no canon is to go alone, but to have a grave brother to accompany him.

The injunction in Item 10th, at this distance of time, appears rather ludicrous; but the visitor seems to be very serious on the oceasion, and says that it has been evidently proved to him that some of the canons, living dissolutely after the flesh, and not after the spirit, sleep naked in their beds without their breeches and shirts, "absque femoralibus et camisiis." He

1 A collation was a meal or repast on a fast day in lieu of a supper.

2 The rule allnded to in item 10th, of not sleeping naked, was enjoined the Knights Templars, who also were subject to the rules of St. Augustine.-See Gertleri Ilist. Templariorum. 
enjoins that these culprits shall be punished by severe fasting, especially if they shall be found to be faulty a third time; and threatens the prior and sub-prior with suspension if they do not correct this enormity.

In Item 11th the good bishop is very wroth with some of the canons, whom lie finds to be professed hunters and sportsmen, keeping hounds, and publicly attending hunting matches. These pursuits, he says, occasion much dissipation, danger to the soul and body, and frequent expense; he, therefore, wishing to extirpate this vice wholly from the convent, "radicious extirpare," does absolutely enjoin the canons never intentionally to be present at any public noisy tumultuous huntings; or to keep any hounds, by theinselves or by others, openly or by stealth, within the convent, or without. ${ }^{1}$

In Item 12th le forbids the canons in office to make their business a plea for not attending the service of the choir; since by these means either divine worship is neglected or their Jrother canons are overburdened.

By Item 14th we are informed that the original number of canons at the Priory of Selborne was fourteen; but that at this visitation they were found to be let down to eleven. The visitor therefore strongly and earnestly enjoins them that, with all due speed and diligence, they should proceed to the election of proper persons to fill up the vacancies, under pain of the greater excommunication.

In Item 17 th, the prior and canons are accused of suffering, through neglect, notorious dilapidations to take place among their manorial houses and tenements, and in the walls and inclosures of the convent itself, to the shame and scandal of the institution: they are therefore enjoined, under pain of suspension, to repair all defects within the space of six months.

1 Considering the strong propensity in human nature towards the pleasures of the chase, it is not to be wondered that the canons of Selborne should languish after hunting, when, from their situation so near the precincts of Wolmer Forest, the king's hounds must have often been in hearing, and sometimes in sight from their windows. If the bishop was so offended at these sporting.canons, what would he have said to our modern foxhunting divines? 
Item 18th. Charges them with grievously burdening the said Priory by means of sales, and grants of liveries ${ }^{1}$ and corrodies. $^{2}$

The bishop, in item 19th, accuses the canons of neglect and omission with respect to their perpetual chantry-services.

Item 20th. The visitor here conjures the prior and canons not to withhold their original alms, "cleemosynas ;" nor those that they were enjoined to distribute for the good of the souls of founders and benefactors: he also strictly orders that the fragments and broken victuals, both from the hall of their prior and their common refectory, should be carefully collected together by their elecmosynarius, and given to the poor without any diminution; the officer to be suspended for neglect or omission.

Item 23rd. He bids them distribute their pittances, "pituncias,"3 regularly on obits, anniversaries, festivals, \&e.

Item 25th. All and every one of the canons are hereby inhibited from standing godfather to any boy for the future, "ne compatres alieujus pueri de cetero fieri presumatis," unless by express license from the bishop obtained; because from such relationship favour and affection, nepotism, and undue influence arise, to the injury and detriment of religious institutions. ${ }^{4}$

1 "Liberationes, or liberatura, allowances of com, \&c. to servants, deliverer at certain times, and certain quantities, as clothes were among the allowanees from religious houses to their dependants."-See the corrodies granted by Croyland abbey.-Hist. of Croyland, Appendix, No. xxxiv.

"It is not improbable that the word in after-ages came to he confined to the uniform of the retainers or servants of the great, who were hence called livery servants."-SIR Johx CuLLuM's Hist. of Hawsted.

- A corrody is an allowance to a servant living in an abbey or priory.

3 "Pitancia, an allowance of bread and beer, or other provision to any pious use, especially to the religious in a monastery, \&e. for augmentation of their commons."-Gloss. to Kennet's Par. Antiq.

4 "The relationship between sponsors and their god-children, who were called spiritual sons and danghters, was formerly esteemed muel more sacred than at present. The presents at christenings were sometimes very considerable : the connection lasted through life, and was closed with a legacy. This last mark of attention seems to have been thought almost indispensable : for, in a will, from whence no extructs have been given, the testator left every one of his god-ehildren a bushel of barley."-SiR Joun Cuncum's Hist. of Hawsted.

"D. Margareta filix Regis primogenitx, quan filiolam, quia ejus in 
Item 26th. The visitor herein severely reprimands the canous for appearing publicly in what would be called in the universities an unstatutable manner, and for wearing of boots, "caligæ de Burneto, et sotularium - in ocrearum loco, ad modum sotularium."1

It is remarkable that the bishop expresses more warmth against this than any other irregularity; and strictly enjoins them, under pain of ecclesiastical censures, and even imprisonment if necessary (a threat not made use of before) for the future to wear boots, "ocreis seu botis," according to the regular usage of their ancient order.

Item 29th. He here again, but with less earnestness, forbids them foppish ornaments, and the affectation of appearing like beaux with garments edged with costly furs, with fringed gloves, and silken girdles trimmed with gold and silver. It is remarkable that no punishment is annexed to this injunction.

Item 31 st. He here singly and severally forbids each canon not admitted to a cure of souls to administer extreme unction, or the sacrament, to clergy or laity; or to perform the service of matrimony, till he has taken out the license of the parish priest.

Item 32nd. The bishop says in this item that he had observed and found, in his several visitations, that the sacramental plate and cloths of the altar, surplices, \&c., were sometimes left in such an uncleanly and disgusting condition as to make the beholders shudder with horror ;- " " quod aliquibus sunt loorrori ;"2

baptismo compater fuit, appellat, cyphum aureum et quadraginta libras, legavit.-Archishor Parker, De Antiquitatc Eccles. Brit. speaking of Archbishop Morton.

${ }^{1}$ Du Fresne is copious on caliga of several sorts. "Hoc item de Clericis, presertim beneficiatis : caligis scacatis (chequered) rubeis, et viridibus publice utentibus dicimis esse censendum."-Statut. Eccles. Tutel. The chequered boots seem to be the Highland plaid stockings.- "Burnetum, i.e. Brunetum, pannus non ex lanâ nativi coloris confectus."-"Sotularium, i.e. subtalaris, quia sub talo est. Peculium geaus, quibus maxime Monachi nocte utebantur in æstate ; in lyeme vero Soccis."

This writer gives many quotations concerning Sotularia, which were not to be made too shapely; nor were the calige to be laced on too nicely.

2 "Men abhorred the offering of the Lord."-1 Sam. chap. ii. v. 17. Strange as this account may appear to modern delicacy, the author, when 
he therefore enjoins them for the future to see that the plate, cloths, and vestments, be kept bright, clean, and in decent order : and, what must surprise the reader, adds - that he expects for the future that the sacrist should provide for the sacrament good wine, pure and unadulterated; and not, as had often been the practice, that which was sour, and tending to lecay:-he says farther, that it seems quite preposterous to omit in sacred matters that attention to decent cleanliness, the neglect of which would disgrace a common convivial meeting. ${ }^{1}$

Item 33rd says that, though the relics of saints, the plate, loly vestments, and books of religious houses, are forbidden by canonical institutes to be pledged or lent out upon pawn; yet, as the visiter finds this to be the case in lis several visitations, he therefore strictly enjoins the prior forthwith to recall those pledges, and to restore them to the convent; and orders that all the papers and title deeds thereto belonging should be safely deposited, and kept under three locks and keys.

In the course of the Visitatio Notabilis the constitutions of Legate Ottobonus are frequently referred to. Ottobonus was afterwards Pope Adrian V. and died in 1276. His constitutions are in Lyndewood's Provinciale, and were drawn up in the 52nd of Henry III.

In the Visitatio Notabilis the usual punishment is fasting on bread and beer; and in cases of repeated delinquency on bread and water. On these occasions quarta feria, et sexta feria, are mentioned often, and are to be understood of the days of the week numerically on which such punishment is to be inflicted.

first in orders, twice met with similar circumstances attending the sacrament at two churches belonging to two obscure villages. In the first he found the inside of the chalice covered with birds' dung; and in the other the communion-cloth soiled with cabbage and the greasy drippings of a gammon of bacon. The good dame at the great farm-house, who was to furnish the cloth, being a notable woman, thought it best to save her clean linen, and so sent a foul cloth that had covered her own table for two or three Sundays before.

1 " . . . . . . ne turpe toral, ne sordida mappa

Corruget nares; ne non et cantharus, et lanx

Ostendat tibi te . . . . . ." 


\section{LETTER XV.}

ThovGH Bishop Wykeham appears somewhat stern and rigid in his visitatorial character towards the Priory of Selborne, yet he was on the whole a liberal friend and benefactor to that convent, which, like every society or individual that fell in his way, partook of the generosity and benevolence of that munificent prelate.

"In the year 1377, William of Wykeham, out of his mere good will and liberality, discharged the whole debts of the prior and convent of Selborne, to the amount of one hundred and ten marks eleven shillings and sixpence; ${ }^{1}$ and, a few years before he died, he made a free gift of one hundred marks to the same Priory: on which account the prior and convent voluntarily engaged for the celebration of two masses a day by two canons of the convent for ten years, for the bishop's welfare, if he should live so long; and for his soul if he should die before the expiration of this term," 2

At this distance of time it seems matter of great wonder to us how these societies, so nobly endowed, and whose members were exempt by their very institutions from every means of personal and family expense, could possibly run in debt without squandering their revenues in a manner incompatible with their function.

Religious houses might sometimes be distressed in their revenues by fires among their buildings, or large dilapidations from storms, \&c.; but no such accident appears to have befallen the Priory of Selborne. Those situate on public roads, or in great towns, where there were shrines of saints, were liable to be intruded on by travellers, devotees, and pilgrims; and were subject to the importunity of the poor, who swarmed at their gates to partake of doles and broken victuals. Of these disadvantages some convents used to complain, and especially those of Canterbury; but this Priory, from its sequestered situation, could

1 Yet in ten years time we find, by the Notabilis Visitatio, that all their relics, plate, vestments, title deeds, \&c. were in pawn.

2 Lowth's Life of Wykeham. 
scldom be subject to either of these inconveniences, and therefore we must attribute its frequent debts and embarrasments, well endowed as it was, to the bad conduct of its nembers, and a general inattention to the interests of the institution.

\section{LETTER XVI.}

BEAUFORT was Bishop of Winchester from 1405 to 1447 ; and yet, notwithstanding this long episcopate, only tom. i. of Beaufort's Register is to be found. This loss is much to be regretted, as it must unaroidably make a gap in the History of Selborne I'riory, and perhaps in the list of its priors.

In 1410 there was an election for a prior, and again in 1411.

In vol. i. p. 24, of Beaufort's Register, is the instrument of the election of John Wyuchestre to be prior-the substance as follows:

Richard Elstede, senior eanon, signifies to the bishop that brother Thomas Weston, the late prior, died October 18th, 1410, and was buried November 11th. That the bishop's license to elect having been obtained, he and the whole convent met in the chapter-house, on the same day, about the hour of vespers, to consider of the election:-that brother John Wynchestre, then sub-prior, with the general consent, appointed the 12th of November, ad horam ejusdem dici capitularem, for the business:-when they net in the chapter-house, post missam de Saneto Spiritu, solemnly celebrated in the church;- to wit, Richard Elstede; Thomas Halyborne; John Lemyngton, secrista; John Stepe, cantor; Walter Ffarnham ; Richard Putworth, celerarius; Hugh Loudon; Henry Brampton, alias Brompton; John Wynchestre, senior; John Wynchestre, junior;-then "Proposito primitus verbo Dei," and then ympno "Veni Creator Spiritus" being solemnly sung, cum "versiculo et oratione," as usual, and his letter of license, with the appointment of the hour and place of election being read, alta voce, in valvis of the chapter-house;-John Wynchestre, senior, the sub-prior, in his VOL. II.

E E 
[LETT.

own behalf and that of all the eanons, and by their manclate, "quasdam monicionem et protestacionem in scriptis redactas fecit, legit, et interposuit "- that all persons disqualified, or not having right to be present, should immediately withdraw; and protesting against their voting, \&e.-that then having read the constitution of the general council "Quia propter," and explained the modes of proceeding to election, they agreed unanimously tc proceed "per viam seu formam simplicis compromissi;" when John Wynchestre, sub-prior, and all the others (the commissaries undernamed excepted) named and ehose brothers Richard Flstede, Thomas Halyborne, John Lemyngton the saerist, John Stepe, chantor, and Richard Putworth, canons, to be commissaries, who were sworn each to nominate and elect a fit person to be prior : and empowered by letters patent under the common seal, to be in force only until the clarkness of the night of the same day; - that they, or the greater part of them, shonld elect for the whole convent, within the limited time, from their own number, or from the rest of the convent;-that one of them shonld publish their consent in eommon before the clergy and people:- they then all promised to receive as prior the person these five canons should fix on. These commissaries seceded from the clapter-house to the refectory of the Priory, and were shut in with master John Penkester, bachelor of laws; and John Couke and John Lynne, perpetual vicars of the parish churehes of Newton and Selborne; and with Sampson Maycock, a public notary; where they treated of the election; when they unanimously agreed on John Wynchestre, and appointed Thomas Halyborne, to choose him in common for all, and to publish the election, as eustomary ; and returned long before it was dark to the chapter-house, where Thomas IIalyborne read publicly the instrument of election; when all the brothers, the new prior excepted, singing solemnly the hymn "Te Deum laudamus," fecerunt deportari novum electum, by some of the brothers, from the chapter-house to the high altar of the church $;^{1}$ and the

i It seems here as if the canons nsed to chair their new elected prior from the chapter-house to the high altar of their convent-church. In Letter XXI. on the same occusion, it is said-"et sic canentes dictum electum ad majus altare ecclesic deduximus, ut apud nus moris est." 
hymn being sung, dictisque versiculo et oratione consuetis in hac parte, Thomas Halyborne, mox tunc ibidem, before the elergy and people of both sexes solemnly published the election in vulgari. Then Richarr Elstede, and the whole convent by their proctors and nuncios appointed for the purposes, Thomas Halyhorne and John Stepe requirerl several times the assent of the electer ; "et tandem post diutinas interpellationes, et deliberationem providam penes se habitam, in hac parte divine nolens, ut asseruit, resistere voluntati," within the limited time he signified his acceptance in the usual written form of words. The bishop is then supplicated to confirm their election, and do the needful, under cornmon seal, in the chapter-house. November 14, 1410.

The bishop, January 6,1410, apud Esher in camerc inferiori, declared the election duly made, and ordered the new prior to be indueted-for this the Archdeacon of Winchester was written to; "stallumque in choro, et locum in capituln juxto morem preteriti temporis," to be assigned him ; and every thing beside necessary to be done.

\section{Beaufort's Register, Vol. I.}

P. 2. Taxatio spiritualis Decanatus de Aulton, Ecclesia de Selebourn, cum Capella,-xxx marc. decima x lib. iii. sol. Vicaria de Selebourn non taxatur propter exilitatem.

P. 9. Taxatio bonorum temporalium religiosorum in Archidiac. Wynton.

Prior de Selebourn habet maneria de

Bromdene taxat. arl . . . . xxx s. ii d. Apud Schete ad . . . . . xvii s. P. Selebourn ad . . . . . vi lib. In civitate Wynton de recldit . vi lib. viii ob. Tannaria sua taxat. ad . . . x lib. s. Summa tax. xxxviii lib. xiiii d. ob. Inde decima vi lib. s. q. ob. 


\section{IETTER XVII.}

Isformatios being sent to Rome respecting the havoe and spoil that was carrying on among the revenues and lands of the Priory of Selborne, as we may suppose by the Bishop of Winchester, its visitor, Pope Martin, ${ }^{1}$ as soon as the news of these proceedings came before him, issued forth a bull, in whicl he enjoins his commissary immediately to revoke all the property that had been alienated.

In this instrument his holiness accuses the prior and canons of having granted away (they themselves and their predeecssors) to certain clerks and laymen their tithes, lands, rents, tenements, and possessions, to some of them for their lives, to others for an uudue term of years, and to some again for a perpetuity, to the great and henvy detriment of the monastery: and these leases were granted, he continues to add, under their own hands, with the sanetion of an oath and the renunciation of all rights and claims, and under penalties, if the right was not made good. But it will be best to give an austract from the bull.

N. 298. Pope Martin's bull, touching the revoling of certain things alienated from the Priory of Seleburne. Pontif. sui ann. 1.

"Martinus Eps. servus servorum Dei. Dileeto filio Priori de Suthvale ${ }^{2}$ Wyntonien. dioc. SaIntem \& apostolicam ben. Ad audientiam nostram pervenit quam tam dilecti filii prior et conventus nowasterii de Selebun per Priorem soliti gubernari

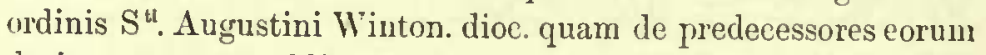
decimas, terras, redditus, domos, passessiones, vineas, ${ }^{3}$ et quedam alia bona ad monasterium ipsum spectantia, datis super hoe

- Pope Martin V.chosen about 1417. He attempted to reform the Clinroh, but died in 1431, just as he had summoned the council of Basil.

2 Should have been no doulbt Southwick, a priory under Portsdown.

${ }^{3} \mathrm{Mr}$. Barrington is of opinion that anciently the English vinea was in almost every instance an orchard; not perhaps always of apples werely, but of other fruits; as cherries, pluns, and currants. We still say a plum or cherry-orchard.-See Vol. iii. of Archælogia.

In the instance above the pope's secretary might insert vineas merely because they were a species of cultivation familar to him in Italy. 
litteris, interpositis juramentis, factis remuntiationibus, et penis adjectis, in gravem ipsius nonasterii lesionem nonnullis clericis et laicis, aliquibus eorum ad vitan, quibusdam vero ad non modicnm tempus, \& aliis perpetuo ad firmam, vel snb censu annuo concesserunt; quorum aliqui dicunt super hiis a sede aplica in communi forma confirmationis litteris inpetrasse. Quia vero nostra interest lesis monasteriis subvenire- [He the Pope here commands] - ea ad jus et proprietatem monasterii studeas legitime revocare," \&c.

The conduct of the religious had now for some time been sgenerally bad. Many of the monastic societies, being very opulent, were become very voluptuous and licentious, and had deviated entirely from their original institutions. The laity saw with indignation the wealth and possessions of their pious ancestors perverted to the service of sensuality and indulgence; and spent in gratifications highly unbecoming the purposes for which they were given. A total disregard of their respective mles and discipline drew on the monks and eanons a heary luad of popular odium. Some good men there were who endeavoured to oppose the general delinqnency; but their efforts were too feeble to stem the torrent of monastic luxury. As far back as the year 1381 Wickliffe's principles and doctrines had made some progress, were well received by men who wished for a reformation, and were defended and maintained by them as long as they dared; till the bishops and clergy began to be so greatly alarmed, that they procured an act to be passed by which the secular arm was empowered to support the corrupt doctrines of the Church; but the first Lollard was not burnt until the year 1401 .

The wits also of those times did not spare the gross morals of the clergy, but boldly ridiculed their ignorance and profligacy. The most remarkable of these were Chaucer, and his contemporary, Robert Langelande, better known by the name of Piers Plowman. The laughable tales of the former are familiar to almost every reader; while the visions of the latter are but in few lands. With a quotation from the "Passus Decimus" of this writer I shall conclude my letter; not only on account of the remarkable prediction therein contained, which carries with it 
somewhat of the air of a prophecy; but also as it seems to have been a striking picture of monastic insolence and dissipation; and a specimen of one of the keenest pieces of satire now perhaps subsisting in any language, ancient or modern.

"Now is religion a rider, a romer by streate;

A leader of love-days, and a loud begger ;

A pricker on a palfrey from maner to maner,

A heape of hounds at his arse, as he a lord were.

And but if his knave kneel, that shall his eope bring,

He lonreth at him, and asketh him who taught him curtesie.

Little had lords to done, to give lands from her heirs,

To religious that have no ruth if it rain on her altars.

In many places ther they persons be, by himself at ease :

Of the poor have they no pity, and that is her charitie ;

And they letten hem as lords, her lands lie so broad.

And there shal come a king, ${ }^{1}$ and confess you religious;

And beate you, as the bible telleth, for breaking your rule,

And amend monials, and monks, aud chanons,

And put hem in her penaunce ad pristinum statum ire."

\section{LETTER XVIII.}

William of Waynflete became Bishop of Winchester in the year 1447, and seems to have pursued the generous plan of Wykeham, in endeavouring to reform the priory of Selborne.

When Waynflete came to the see he found Prior Stype, alias Stepe, still living, who had been elected as long ago as the year 1411.

1 F. l. a. "This prediction, although a probable conclusion concerning a king who after a time would suppress the religious houses, is renarkable. I inlagined it might have been foisted into the copies in the reign of king Henry VIII., but it is to be found in MSS. of this poem older than the year 1400." Fol. l. a. b.

"Again, where he, Piers Plowman, alludes to the Knight Templars, lately suppressed, he says,

". . . . . . . Men of holie kirk

Shall turm as Templars did ; the tyme approacheth nere."

"This, I suppose, was a favourite doctrine in Wickliffe's discourses." W Artow's Hist. of English Poetry, vol. i. p. 282. 
Among my documents I find a curious paper of the things put into the custody of Peter Bernes the sacrist, and especially soine relics: the title of this evidence is "No. 50. Indentura prioris de Selborne quorundam tradit. Petro Bernes sacristx, ibidem, anu. Hen. VI. . . . una cum confiss. ejusdem Petri script." The occasion of this catalogue, or list of effects, being drawn between the prior and sacrist does not appear, nor the date when; only that it happened in the reign of Henry VI. This transaction probably took place when Bernes entered on his office; and there is the more reason to suppose that to be the case, becanse the list consists of vestments and implements, and relics such as belonged to the church of the Priory, and fell under the care of the sacrist. I shall just mention the relics, although they are not all specified ; and the state of the live stock of the monastery at that juncture.

"Item 2. osculator. argent.

"Item 1. osculatorium cum ossc digiti auricular.-S". Johannis Baptistre. ${ }^{1}$

"Item 1. parvam cruccm cum V. reliquiis.

"Jtem 1. anulum argent. et deauratum St. Edmundi."

"Item 2. osculat. de coper.

"Item 1. junctorium St. Ricardi. ${ }^{3}$

"Item 1. pecten St. Ricardi." 4

1 How the convent came by the bone of the little finger of St. John the Baptist does not appear; probably the founder, while in Palestine, purehased it among the Asiatics, who were at that time great traders in relics. We know from the best authority that as soon as Herod lad cruelly beheaded that holy man, "his diseiples came and took up the body and buried it, and went and told Jesus."-Matt. iv. 12.-Farther it would be difficult to say.

${ }^{2}$ November 20 , in the calendar, Edmund, king and martyr, in the ninth century.-See also a Sanctus Kdmundus in Godwin, among the arrhbishops of Canterbury, in the thirteenth century; his surname Rich, in 1234.

3 April 3, ibid. Richard, Bishop of Chicester, in the thirteenth century ; his surname De la Wich, in 1245.

Junctorium, perhaps a joint or limb of St. Riehard; but what particular joint the religious were not such osteologists as to specify. This barbarous word was not to be found in any dictionary consulted by the author.

+ "Pecten inter ininisteria sacra recensetur, quo scil. sacerdotes ac clerici, 
The staurum, or live stock, is quite ridiculous, consisting only of " 2 vacee, 1 sus, 4 hoggett. et 4 porcell." viz. two cows, one sow, four porkers, and four pigs.

\section{LETTER XIX.}

STEPE died towards the end of the year 1153 , as we may suppose pretty far advanced in life, having been prior fortyfour years.

On the very day that the vacancy happened, viz. January 26 , 1453-4, the sub-prior and convent petitioned the visitor-_"vos unicum levamen nostrum, et spem unanimiter rogamus, quatinus eligendum ex nobis unum confratrem de gremio nostro, in nostra religione probatum et experten, licenciam vestram paternalem cum plena libertate nobis concedere dignemini graciose."-Reg. Waynflete, tom. i.

Instead of the license requested we find next a corrmission "custodie prioratus de Selebourne durante vacatione," addressed to brother Peter Berne, canon-regular of the Priory of Selebourne, and of the order of St. Augustine, appointing him keeper of the said Priory, and empowering him to collect and receive the profits and revenues, and "alia bona" of the said Priory; and to exercise in every respect the full power and authority of a prior; but to be responsible to the visitor finally, and to maintain this superiority during the bishop's pleasure only. This instrument is dated from the bishop's manor-honse in Southwark, March 1, 1453-4, and the seventli of his consecration.

After this transaction it does not appear that the chapter of the P'riory proceeded to any election: on the contrary, we find that at six months' end from the vacancy the visitor declared that a lapse had taken place; and that therefore he did confer

antequam in ecclesiam procederent, crines pecterent. E quibus colligitur monachos, tunc temporis, non omnino tonsos fuisse."-Du Fresne.

The author remembers to have seen in great farm houses a fanily comb chained to a post for the use of the hinds when they came in to their meals. 
the priorship on Peter Berne.- " Prioratum vacantem et ad nostran collationem, seu provisionem jure ad nos in hac parte per lapsum temporis legitime devoluntu spectantem, tibi (sc. P. Berne) de legitimo matrimonio procreato, \&c.-conferimus," \&c. This deed bears date, July 28, 1454.-Reg. Waynflete, tom. i. p. 69 .

On February 8, 1462, the visitor issued out a power of sequestration against the Priory of Selborne on account of notorious dilapidations which threatened manifest ruin to the roofs, walls, and edifices of the said convent; and appointing John Hammond, B.D., rector of the parish ehureh of Hetlegh, Joln Hylling, vicar of the parish ehurch of Newton Valence, and Walter Gorfin, inhabitant of the parish of Selborne, his sequestrators, to exact, collect, levy, and receive, all the profits and revenues of the said convent: he adds, "ac ea sub areto, et tuto custodiatis, custodirive faciatis ; " as they would answer it to the bishop at their peril.

In consequence of these proceedings Prior Rerne, on the last day of February, and the next year, produced a state of the revenues of the Priory, No. 381, called " $A$ paper conteyning the value of the manors and lands pertayning to the Priory of Selborne. 4 Edward III. with a note of charges yssuing ont of it."

This is a curious document. From circumstances in this paper it is plain that the sequestration produced good effects; for in it are to be found bills of repairs to a considerable amount.

By this evidence also it appears that there were at that jumcture only four canons at the Priory $;^{1}$ and that these, and their four household servants, during this sequestration, for their clothing, wages, and diet, were allowed per ann. $\mathrm{xxx}$ lib. ; and that the annual pension of the lord prior, reside where he would, was to be $\mathrm{x}$ lib.

In the year 1468 , Prior Berne, probably wearied out by the

1 If Bishop Wykeham was so disturbed (see Notab. Visitatio) to find the number of canons reduced from fourteen to eleven, what would he have said to have seen it diminished below one third of that number?

VOL. II. 
dissensions and want of order that prevailed in the convent resigned his priorship into the liands of the bishop.-Reg. Waynflete, tom i. pars $\mathrm{I}^{\mathrm{ma}}$, fol. 157.

March 28, A.D. 1468. "In quadam alta camera juxta magnam portam mrnerii of the Bishop of Wynton de Waltham coram eodem rev. patre ibidem tunc sedente, Peter Berne, prior of Selborne, ipsum prioratum in sacras, et venerabiles manus of the bishop, viva voce libere resignavit: and lis resignation was admitted before two wituesses and a notary-public. In consequence, Marcl 29 th, before the bishop, in capella manerii sui ante dicti pro tribunali sedente, comparuerunt fratres" Peter Berne, Thomas London, William Wyndesor, and William Paynell, alias Stretford, canons regular of the Priory, "capitulem, et conventum ejusdem ecclesie facientes; ac jus et voces in electione fintura prioris dicti prioratus solum et in solidum, ut asserverunt, habentes;" and after the bishop had notified to them the vacancy of a prior, with liis free license to elect, deliberated a while, and then, by way of compromise, as they affirmed, unanimously transferred their right of election to the bishop before witnesses. In consequence of this the bishop, after full deliberation, proceeded, April 7th, "in capella manerii sui de Waltham," to the election of a prior; "et fratrem Johannem Morton, priorem ecclesie conventualis de Reygate dicti ordinis $\mathrm{S}^{\mathrm{ti}}$ Augustini Wynton. dioc. in priorem vice et nomine omnium et singulorum canonicornm predictorum elegit, in ordine sacerdotali, et etate licita constitutum, \&c." And on the same day, in the same place, and before the same witnesses, John Morton resigned to the bishop the priorship of Reygate viva voce. The bishop then required his consent to his own election; "qui licet in parte renitens tanti reverendi patris se confirmans," obeyed, and signified his consent oraculo vive vocis. Then was there a mandate citing any one who would gainsay the said election to appear before the bishop or his commissary in his chapel at Farnham on the 2nd day of May next. The dean of the deanery of Aulton then appeared before the chancellor, his commissary, and returned the citation or mandate dated April 22nd, 1468, with signification, in writing, of his having published it as required, dated Newton Valence, May 1st, 1468. 
This certificate being read, the four canons of Selborne appeared and required the election to be confirmed; et ex super abundanti appointed William Long their proctor to solicit in their name that he inight be canonically confirmed. John Morton also appeared, and proclamation was made; and no one appearing against him, the commissary pronounced all absentees eontunacions, and preeluded them from objecting at any other time; and, at the instance of John Morton and the proctor, confirmed the election by his deeree, and directed his mandate to the rector of Hedley and the vicar of Newton Valence to install him in the usual form.

Thus, for the first time, was a person, a stranger to the convent of Selborne, and never canon of that monastery, elected prior; though the style of the petitions in former elections used to run thus,- "Vos . . . rogamus quatinus eligendum ex nobis unum confratrem de gremio nostro,-_icentialn vestram-nobis concedcre dignemini."

\section{LETTER XX.}

Prior Morton dying in 1471 , two canons, by themselves proceeded to election, and chose a prior; but two more (one of them Berne) complaining of not being summoned, objected to the proceedings as informal; till at last the matter was compromised that the bishop should again, for that turn, nominate as he had before. But the circumstances of this election will be best explained by the following extract:

\section{Reg. Waynflete, tom. ii. pars $\mathrm{I}^{\mathrm{ma}}$, fol. 7 .}

William Wyndesor, a canon-regular of the Priory of Selborne, having been elected prior on the death of Brother John, appeared in person before the bishop in his chapel at South Waltham. He was attended on this occasion by Thomas London and John Bromesgrove, canons, who elected him. Peter Berne and 
William Stratfield, canons, also presented themselves at the same time, complaining that in this business they had been overlooked, and not summoned; and that therefore the validity of the election might with reason be called in question, and quarrels and dissensions might probably arise between the newly chosen prior and the parties thus neglected.

After some altercation and dispute they all came to an agreement with the new prior, that what had been done should be rejected and annulled; and that they would again, for this turn, transfer to the bishop their power to elect, order, and provide them another prior, whom they promised unanimously to admit.

The bishop accepted of this offer before witnesses; and on September, 27, in an inner chamber near the chapel above-mentioned, after full deliberation, chose brother Thomas Fairwise, vicar of Somborne, a canon-regular of St. Angustine in the Priory of Bruscough, in the diocese of Coventry and Lichfield, to be prior of Selborne. The form is nearly as above in the last election. The canons are again enumerated; W. Wyndesor, sub-prior, P. Berne, T. London, W. Stratfield, J. Bromesgrove, who had formed the chapter, and had requested and obtained license to elect, but had unanimously conferred their power on the bishop. In consequence of this proceeding, the bishop taking the business upon himself, that the Priory might not suffer detriment for want of a governor, appoints the aforesaid T. Fairwise to be prior. A citation was ordered as above for gainsayers to appear October 4th, before the bishop or his commissaries at South Waltham; but none appearing, the commissaries admitted the said Thomas, ordered lim to be installed, and sent the usual letter to the convent to render him due obedience.

'Thus did the Bishop of Winchester a second time appoint a stranger to be prior of Selborne, instead of one chosen out of the chapter. For this seeming irregularity the visitor had no doubt good and sufficient reasons, as probably may appear hereafter. 


\section{LETTER XXI.}

Whatever might have been the abilities and disposition of Prior Fairwise, it conld not have been in his power to have brought about any material reformation in the Priory of Selborne, because he departed this life in the month of August, 1472 , before he had presided one twelvemonth.

As soon as their governor was buried, the chapter applied to their visitor for leave to cloose a new prior, which being grinted, after deliberating for a time, they proceeded to an election by a scrutiny. But as this mode of voting has not been described, an extract from the bishop's register, representing the manner more fully, may not be disagreeable to several readers.

Waynflete lieg. tom. ii. pars $\mathbf{I}^{\text {ma }}$, fol. 15.

"Reverendo, \&c., ac nostro patrono graciosissimo vestri humiles, et devote obedientie filii," \&e.

To the right reverend Father in God, and our most gracious patron, we, your obedient and devoted sons, Willian Wyndesor, president of the chapter of the Priory of Selborne, and the convent of that place, do make known to your lordship, that our priorship being lately vacant by the death of Thomas Fairwise, our late prior, who died August 11th, 1472, having committed his body to decent sepulture, and having. requested, according to custom, leave to elect another, and having obtained it under your seal, we William Wyndesor, president of the convent, on the 29th of August, in our chapter-house assembled, and making a chapter, taking to us in this business Richard ap Jenkyn, and Galfrid Bryan, chaplains, that our said Priory might not by means of this vacancy incur harm or loss, unanimously agreed on August the last for the day of election; on which day, having first celebrated mass, "De sancto spiritu," at the high altar, and having called a cliapter by tolling a bell about ten o' the clock, we, William Wyndesor, president, Peter Berne, 'Thomas London, 
and William Stratfeld, canons, who alone liad voices, being the only canous, about ten o' the clock, first sung "Veni Creator," the letters and license being read in the presence of many persons there. Then William Wyndesor, in his own name, and that of all the canons, made solemn proclamation, enjoining all who had no right to vote to depart out of the chapter-house. When all were withdrawn except Guyllery de Lacuna, in decretis Baccalarius, and Robert Peverell, notary-public, and also the two chaplains, the first was requested to stay, that he might direct and inform us in the mode of election; the other, that he might record and attest the transactions; and the two last that they might be witnesses to them.

Then, having read the constitution of the general council "Quia propter," and the forms of elections contained in it being sufficiently explained to them by De Lacuna, as well in Latin as the vulgar tongue, and having deliberated in what mode to proceed in this election, they resolved on that of scrutiny. Three of the canons, Wyndesor, Berne, and London, were made scrutators: Berne, London, and Stratfeld, choosing Wyndesor; Wyndesor, London, and Stratfeld, choosing Berne; Wyndesor, Berne, and Stratfeld, choosing London.

They were empowered to take each other's vote, and then that of Stratfeld; "et ad inferiorem partem angularem " of the chapter-house, "juxta ostium ejusdem declinentes," with the other persons (except Stratfeld, who stayed behind), proceeded to voting, two swearing, and taking the voice of the third, in succession, privately. Wyndesor voted first: "Ego credo Petrum Berne meliorem et utiliorem ad regimen istius ecclesie, et in ipsum consentio, ac cum nomino," \&c. Berne was next sworn, and in like manner nominated Wyndesor; London nominated Berne: Stratfeld was then called and sworn, and nominated Berne.

"Quibus in scriptis redactis," by the notary-public, they returned to the upper part of the chapter-house, where by Wyndesor " sic purecta fecerunt in communi," and then solemnly, in form written, declared the election of Berne: when all, "antedicto nostro electo excepto, approbantes et ratificantes, cepimus decantare solemniter 'Te Deum Laudamus,' et sic 
canentes dictum electumn ad majus altare ecelesie deduximus, ut apud nos est moris." Then Wyndesor "electionem clero et populo infra chorum dicte ecclesie congregatis publicavit, et personam electi publice et personaliter ostendit." We then returned to the chapter-house, except our prior; and Wyndesor was appointed by the other two their proctor, to desire the assent of the elected, and to notify what had been done to the bishop; and to desire hiin to confirm the election, and do whatever else was necessary. Then their proctor, before the witnesses, required Berne's assent in the chapter-house: "qui quidem instanciis et precibus multiplicatis devictus," consented, "licet indignus electus," in writing. They therefore requested the bishop's confirmation of their election "sic canonice et solemniter celebrata," \&c. \&c. Sealed with their common seal, and subscribed and attested by the notary. Dat. in the chapterhouse, September 5 th, 1472 .

In consequence, September 11th, 1472, in the bishop's chapel at Esher, and before the bishop's conmissary, appeared W. Wyndesor, and exlibited the above instrunent, and a mandate from the bishop for the appearance of gainsayers of the election there on that day:-and no one appearing, the absentees were declared contnmacious, and the election confirmed; and the vicar of Aulton was directed to induct and install the prior in the usual manner.

Thus did Canon Berne, thongh advanced in years, reassume his abdicated priorship for the second time, to the no small satisfaction, as it may seem, of the Bishop of Winchester, who professed, as will be shown not long hence, a high opinion of his abilities and integrity.

\section{IETTER XXII.}

As Prior Berne, when chosen in 1454, held his priorship only to 1468 , and then made a voluntary resignation, wearied and disgusted, as we may conclude, by the disorder that prevailed in his convent; it is no matter of wonder that, when re- 
chosen in 1472, he should not long maintain his station; as oll age was then coming fast upon him, and the increasing anarcliy and misrule of that declining institution required unusual vigour and resolution to stem that torrent of profligacy which was hurrying it on to its dissolution. We find, accordingly, that in 1478 he resigned his dignity again into the hands of the bishop.

\section{Waynflete Reg. Fol. 55.}

\section{Resignatio Prioris de Seleborne.}

May 14, 1478. Peter Berne resigned the priorship. May 16, the bishop admitted his resignation "in manerio suo de Waltham," and declared the priorship void; "et priorat. solacio destitutum esse;" and granted his letters for proceeding to a new election: when all the religious, assembled in the chapterhouse, did transfer their power under their seal to the bishop by the following public instrument:

"In Dei nomine Amen," \&c. A.D. 1478, Maii 19. In the chapterhouse for the election of a prior for that day, on the free resignation of Peter Berne, having celebrated in the first place mass at the high altar "De spiritu sancto," and having called a chapter by tolling a bell, ut moris est ; in the presence of a notary and witnesses appeared personally Peter Berne,Thomas Ashford, Stephen Clydgrove, and John Ashton, presbyters, and Henry Canwood," in chapter assembled; and after singing the hymn "Veli Creator Spiritus," "cum versiculo et oratione 'Deus qui corda ;' declarataque licentia Fundatoris et patroni; futurum priorem eligendi concessa, et constitutione consilii generalis que incipit 'Quia propter' declaratis; viisque per quas possent ad hanc electionem procedere," by the decretorum doctorem, whom the canons had taken to direct them-they all and every one " dixe-

1 Here we see that all the canons were changed in six years; and that there was quite a new chapter, Berno excepted, between 1472 and 1478 ; for, instead of Wyndesor, London, and Stratfeld, we find Ashford, Clydgrove, Ashton, and Canwood, all new men, who were soon gone in their turn off the stage, and are heard of no more. For, in six years after, there seem to have been no canons at all. 
runt et affirmarunt se nolle ad aliquam viam procedere:"-but, for this turn only, renounced their right, and unanimously transferred their power to the bishop, the ordinary of the place, promising to receive whom he should provide; and appointed a proctor to present the instrument to the bishop under their seal; and required their notary to draw it up in due form, \&c. subscribed by the notary.

After the visitor had fully deliberated on the matter, he proceeded to the choice of a prior, and elected, by the following instrument, John Sharp, alias Glastonbury.

\section{Fol. 56. Provisio Prioris per EipM.}

Willunus, \&c. to our beloved brother in CHrist, John Sharp, alias Glastonbury, Ecclesie conventualis de Bruton, of the order of St. Austin, in the diocese of Bath and Wells, canon-regularsalutem, \&c. "De tue circumspectionis industria plurimum confidentes, te virum providum et discretum, literarum scientia, et moribus merito commendandum," \&c.--do appoint you priorunder our seal. "Dat. in manerio nostro de Suthwaltham, May 20, 1478, et nostre Consec. 31."

Thus did the bishop, three times out of the four that he was at liberty to nominate, appoint a prior from a distance, a stranger to the place, to govern the convent of Selborne, hoping by this method to have broken the cabal, and to have interrupted that habit of mismanagement that had pervaded the society : but he acknowledges, in an evidence lying before us, that he never lid succeed to his wishes with respect to those late governors,"quos tamen male se habuisse, et inutiliter administrare, et administrasse usque ad presentia tempora post debitam investigationem, \&c. invenit." The only time that he appointed from among the canons, he made choice of Peter Berne, for whom he hark conceived the greatest esteem and regard.

When Prior Berne first relinquished his priorship, he returned again to his former condition of canon, in which he continued for some years: but when he was rechosen, and had abdicated a second time, we find him in a forlorn state, and in danger of being reduced to beggary, had not the Bishop of Winchester

YOL. II.

G G 
interposed in his favour, and with great humanity insisted on a provision for him for life. The reason for this difference seems to have been, that, in the first case, though in years, he might have been hale and capable of taking his share in the duty of the convent; in the second, he was broken with age, and no longer equal to the functions of a canon.

Impressed with this idea the bishop very benevolently interceded in his favour, and laid his injunctions on the new elected prior in the following manner.

Fol. 56. "In Dei nomine Amen. Nos TVillmus, \&c. considerantes Petrum Berne," late prior "in administratione spiritualium et temporalium prioratus laudabiliter vixisse et rexisse ; ipsumque senio et corporis debilitate confractum; ne in opprobrium religionis mendicari cogatur;-eidem annnam pensionem a Domino Johanne Sharp, alias Glastonbury, priore moderuo," and his successors, and, from the Priory or chureh, to be pair every year during his life, "de voluntate et ex consensu expressis" of the said John Sharp, "sub ea que sequitur forma verborum-assignamus:"

1st. That the said prior and his successors, for the time being, honeste extuibebunt of the fruits and profits of the priorship, " eidem esculenta et poculenta," while he remained in the Priory, "sub consimili portione eorundem prout convenienter jriori," for the time being, ministrari contigerit; and in like manner uni famulo, whom he should choose to wait on him, as to the scrvientibus of the prior.

Item. "Invenient sen exhibebunt eidem unam honestam cameram" in the Priory, "cum focalibus necessariis seu opportunis ad eundem"

Item. We will, ordain, \&c. to the said P. Berne an annual pension of ten marks, from the revenue of the Priory, to be paid hy the hands of the prior quarterly.

The bishop decrees farther, that Jolnn Sharp, and his successors, shall take an oath to observe this injunction, and that before their installation.

"Lecta et facta sunt hæc in quondam alto oratorio," belonging to the bishop at Suthwalthan, May 25, 1478, in the presence of John Sharp, who gave his assent, and then took the oath before 
witnesses, with the other oaths before the chancellor, who decreed he should be inducted and installed; as was done that saine day.

How John Sharp, alias Glastonbury, nequitted himself in his priorship, and in what manner he made a vacancy, whether by resignation, or death, or whether he was removed by the visitor; (loes not appear: we only find that some time in the year 1484 , there was no prior, and that the bishop nominated canon Ashford to fill the vacancy.

\section{LETTER XXIII.}

Tuls Thomas Ashford was most undoubtedly the last prior of Selborne; and therefore here will be the proper place to say something concerning a list of the priors, and to endeavour to improve that already given by others.

At the end of Bishop Tanner's "Notitia Monasticn," the folio edition, among Brown Willis's Principals of Religious Honses, nccur the names of eleven of the priors of Sclborne, with dates. But this list is imperfect, and particularly at the beginning; for though the Priory was founded in 1232 , yet it commences with Nich. de Cantia, elected in 1262 ; so that for the first thirty years no prior is mentioned; yet there must have been one or more. We were in hopes that the register of l'eter de Rupibus would have rectified this omission ; but, when it was examinerl, no information of the sort was to be found. From the year 1410 the list is much corrected and improved; and the reader may depend on its being thenceforward very exact.

A List of the Priors of Selborne Priory, from Brown Willis's Principals of Religions Houses, with additions within [ ] by the Anthor.

[.John - was prior, sine dat. $\left.{ }^{1}\right]$

Nicl. de Cantia el. . . . . . . . . . 1262.

1 See, in Letter XI. of these Antiquities, the reason why prior John - who had transactions with the Knight Templars, is placed in the list before the year 1262 . 
[Peter — was prior in . . . . . . . . 1271.]

[Richard — was prior in . . . . . . . 1280.]

Will. Basing was prior in . . . . . . . . 1299.

Walter de Insula el. in . . . . . . . . . 1324

[Some difficulties, and a.devolution; but the election confirmed by Bishop Stratford.]

John de Wintōn . . . . . . . . . . . . 1339.

Thromas Weston . . . . . . . . . . 1377.

Jolin Winchester [Wynchestre] . . . . . . . 1410.

[Elected by Bishop Beaufort "per viam vel formam simplicis compromissi.”]

[John Stype, alias Stepe, in . . . . . . . . . 1411.]

Peter Bene [alias Berne or Bernes, appointed keeper, and, by lapse to Bishop Wayneflete, prior] in . . . 1454. [He resigns in 1468.]

John Morton [Prior of Reygate] in . . . . . . . 1468.

[The canons by compromise transfer the power of election to the bishop.]

Will. Winsor [Wyndesor, prior for a few days] . . 1471.

[but removed on account of an irregular election.]

Thomas Farwill [Fairwise, vicar of Somborne] . . . 1471.

[by compromise again elected by the bishop.]

[Peter Berne, re-elected by scrutiny in . . . . . . 1472.]

[resigns again in 1478.]

John Sharper [Sharp] alias Glastonbury ' . . . . . 1478.

[Canon-reg. of Bruton, elected by the bishop by compromise.]

[Thomas Ashford, canon of Selborne, last prior elected

by the Bishop of Winchester, some time in the year 1484 . and deposed at the dissolution.]

\section{LETTER XXIV.}

Bishop Wanffleet's efforts to continue the Priory still proved unsuccessful; and the convent, without any caunons, and for some time without a prior, was tending swiftly to its dissolution.

When Sharp's, alias Glastonbury's priorship ended does not 
appear. The bishop says that he had been obliged to remove some priors for mal-adninistration : but it is not well explained how that could be the ease with any, unless with Sharp; because all the others, chosen during his episcopate, died in their office, viz. Morton and Fairwise; Berne only excepted, who relinquished twice voluntarily, and was moreover approved of by Wainfleet as a person of integrity. But the way to show what ineffectual pains the bishop took, and what difficulties he met with, will be to quote the words of the libel of his proctor, Radulphus Langley, who appeared for the bishop in the process of the impropriation of the Priory of Selborne. The extract is taken from an attested copy.

"Item-that the said bishop-dicto priuratui et personis ejusdem pie compatiens, sollicitudines pastorales, labores, et diligentias gravissimas quam plurimas, tam per se quam per suos, pro reformatione premissorum inpendebat: et aliquando illius loci prioribus, propter malam et inutilem adninistrationem, et dispensationem bonorum predicti prioratus, suis demeritis exigentibus, amotis; alios priores in quorum eircumspectione et diligentia confidebat, prefeeit: quos tamen male se habuisse ae inutiliter administrare, et administrasse, usque ad presentia temporn post debitam investigationem, \&e. invenit." So that he despaired, with all his care,- "statum ejusdem reparare vel restaurare: et considerata temporis malicia, et preteritis timendo, et conjecturando futura, de aliqua bona et sancta religione ejusdem ordinis, \&c. juxta piam intentionem primevi fundatoris ibidem labend. desperatur."

William Wainfleet, Bishop of Winchester, founded his college of St. Mary Magdalen, in the university of Oxford, in or about the year 1459 ; but the revenues proving insufficient for so large and noble an establishment, the college supplicated the founder to augment its income by putting it in possession of the estates belonging to the Priory of Selborne, now become a deserted convent, without canons or prior. The president and fellows state the circumstances of their numerous institution and scanty provision, and the ruinous and perverted condition of the Priory. The bishop appoints commissaries to inquire into the state of the said monastery ; and, if found expedient, to confirm the appropria- 
tion of it to the college, which soon after appoints attorneys to take possession, September 24, 1484. But the way to give the reader in thorough insight respecting this transaction, will be to transcribe a farther proportion of the process of the impropriation from the beginning, which will lay open the manner of proceeding, and show the consent of the parties.

\section{Impropriatio Selborne, 1485}

" Universis sancte matris ecclesie filiis, \&c. Rieardus Dei gratia prior ecclesie conventualis de Novo Loeo, \&c. ${ }^{1}$ ad universitatem vestre notitie deducimus, \&c. quod coram nobis commissario predicto in ecclesia parochiali Sti. Georgii de Essher, diet. Winton. dioc. 30. die Augusti, A. D. 1485. Indictione tertia pontificat. Innocentii $8^{\text {vi }}$. ann. $1^{\text {mo }}$. judicialiter comparuit venerabilis vir Jacobus Preston, S. T. P. infrascriptus, et exlibuit literas commissionis-quas quidem per magistrum Thoman Somereotes notarium publicum, \&c. legi fecimus, tenorem sequentem in se continentes." The same as No. 103, but dated"In manerio nostro de Essher, Augusti, ${ }^{\text {mo }}$. A. D. 1485, et nostre consec. anno 39." [No. 10.) is repeated in a book containing the like process in the preceding year by the same commissary, in the parish church of St. Andrew the apostle, at Farnlam, Sept. 6th, anno 1484.] "Post quarum literarum lecturam-dictus nugister Jacobus Preston, quasdam procuratorias literas mag. Richardi Mayewe presidentis, ut asseruit, collegii beate Marie Magdalene, \&c. sigillo rotundo communi, \&c. in cera rubea inpresso sigillatas realiter exhibuit, \&c. et pro eisdem İnis suis, E. fecit se partem, ac nobis supplicavit ut juxta formam in

1 Ecclesia Conventualis de Novo Loco was the monastery afterwards called the New Minster, or Abbey of Hyde, in the city of Winchester. Should any intelligent reader wonder to see that the prior of Hyde Abbey was commissary to the Bishop of Winton, and should conclude that there was a mistake in titles, and that the abbot must have been here meant, he will be plcased to recollect that this person was the second in rank ; for, "next under the abbot, in every abbey, was the prior."-Pref. to Notit. Monast. p. xxix. Besirles, abbots were great personages, and too high in station to submit to any office under the bishop. 
eisclem traditam procedere dignaremur, \&c." After these proclamations no contradictor or abjector appearing - " ad instanten petitionem ipsius mag. Jac. Preston, procuratoris, \&c. procedendum fore decrevimus vocatis jure vocandis; nee non mag. Tho. Somereotes, \&c. in aetorum nostrorum scribam nominavimus. Consequenter et ibidem tune comparuit magister Michael Clyff, \&c. et exlibuit in ea parte procuratorium suum," for the prior and convent of the cathedral of Winton, "et fecit se partem pro eisdem.-Deinde coinperuit coram nobis, \&c. honestus vir Willmus Cowper," proetor for the bishop as patron of the Priory of Selborne, and exhibited his "procuratorium," \&c. After these were read in the presence of Clyff" and Cowper, "Preston, viva voce," petitioned the commissary to annex and appropriate the Priory of Selborne to the college- "propter quod fructus, redditus, et proventus ejusdem coll. adeo tenues sunt, et exiles, quod ad sustentationem ejus, \&c. non sufficiunt."-The commissary, "ad libellandum et articulandum in scriptis"-adjourned the court to the 5th of August, then to be held again in the parish chureh of Essher.

W. Cowper being then absent, Radulphus Langley appeared for the bishop, and was admitted his proctor. Preston produced his libel or article in scriptis for the union, \&c. " et admitti petiit eundem cum effectu; cujus libelli tenor sequitur.-In Dei nomine, Amen. Coram nobis venerabili in Cluristo patre Richardo, priore, \&c. de Noro Loco, \&e. commissario, \&e." Part of the college of Magd. dicit. allegat. and in his "scriptis proponit," \&e.

"Imprimis"- -that said college consists of a president and eighty scholars, besides sixteen choristers, thirteen "servientes inibi altissimo famulantibus, et in scientiis plerisque liberalibus, presertim in sacra theologia studentibus, nedum ad ipsorum presidentis et scholarium pro presenti et imposterum, annuente deo, incorporandorum in eodem relevamen; verum etiam ad omnium et singulorum tam scholarium quam religiosorum cujuscunque ordinis undequaque illue confluere pro salubri doctrina volentiun utilitatem inultiplicem ad incrementa virtutis fideique catholice stabilimentum. Ita videlicet quod omnes et singuli absque personarum sen nationum delectu illuc accedere volentes, lecturas 
publicas et doctrinas tam in grammatica loco ad collegium contigno, ac philosophiis morali et naturali, quam in sacra theologia in eodem collegio perpetuis temporibus continuandas libere atque gratis audire valeant et possint ad lauden gloriam et honorem Dei, \&c. extitit fundatın et stabilitum."

For the first item in this process see the beginning of this letter. Then follows item the second-."that the revenues of the college non sufficiunt his diebus." "Iten-that the premisses are true, \&c. et super eisclem laborarunt, et laborant publica vox et fama. Unde facta fide petit pars eorundem that the Priory be annexed to the college: ita quod disto prioratu vacante liceat iis ex tunc to take possession," \&c. This libel, with the express consent of the other proctors, we, the commissary, adnitted, and appointed the 6th of August for proctor Preston to prove the premisses.

Preston produced witnesses, W. Gyfford, S.T.P., John Nele, A.M., John Chapman, chaplain, and Robert Baron, literatus, who were admitted and sworn, when the court was prorogued to the 6th of August; and the witnesses, on the same 5th of August, were examined by the commissary, "in capella infra manerium de Essher situata, secrete et singillatim." Then follow the "literæ procuratorix:" first that of the college, appointing Preston and Langport their proctors, dated August 30th, 1484; then that of the prior and convent of the cathedral of Winton, appointing David Husband and Michael Cleve, dated September 4th, 1484: then that of the bishop, appointing W. Gyfford, Rarlulphus Langley, and Will. Cowper, dated September 3rd, 1484. Consec. 38 . - "Quo die adveniente in dicta ecclesia parochiali," appeared "coram nobis" James Preston to prove the contents of his libel, and exhibited some letters testimonial with the seal of the bishop, and these were admitted; and consequenter. Preston produced two witnesses, viz. Dominum Thomam Ashforde nuper priorem dicti prioratus, et Willm. Rabbys literatum, who were admitted and sworn, and exaniner as the others, by the commissary; "tunc \& ibiclem assistente scriba secrete \& singillatim;" and their depositions were read and made public, as follows : 
Mr. W. Gyfford, S. T. P. aged 57, of the state of Magd. Coll. \&c. \&c. as before:

Mr. John Nele, aged 57, proves the articles also :

Robert Baron, aged 56 :

Johannes Chapman, aged 35 , also affirmed all the five articles :

Dompnus Thomas Ashforde, aged 72 years- "dicit $2^{\text {dum }} 3^{\text {nm }}$ $4^{\text {um }}$ articulos in eodem libello contentos, concernentes statum dicti prioratus de Selebourne, fuisse et esse veros."

W. Rabbys, ætat. 40 ann. agrees with Gyfford, \&c.

Then follows the letter from the bishop, "in subsidium probationis," above mentioned_- "Willmus, \&c. salutem, \&c. noverint universitas vestra, quod licet nos prioratui de Selebourne, \&c. pie compacientes sollicitudines pastorales, labores, diligentias quamplurimas per nos \& conmissarios nostros pro reformatione status ejus impenderimus, justicia id poscente; nihilominus tamen," \&c. as in the article - to "desperatur," dated "in manerio nostro de Essher, Aug. 3d. 1485, \& consec. 39." Then, nn the 6th of August, Preston, in the presence of the other proctors, required that they should be compelled to answer; when they all allowed the articles "fuisse \& esse vera;" and the conmissary, at the request of Preston, concluded the business, and appointed Monday, Aug. 8th, for giving his decree in the same church of Essher; and it was that day read, and contains a recapitulation, with the sentence of union, \&c. witnessed and attested.

As soon as the president and fellows of Magdlalen College had obtained the decision of the commissary in their favour they proceeded to supplicate the pope, and to entreat his holiness that he would give his sanction to the sentence of union. Some difficulties were started at Rome; but they were surmounted by the college agent, as appears by his letters from that city. At length Pope Innocent VIII. by a bull ${ }^{1}$ bearing

1 There is nothing remarkable in this bull of Pope Innocent except the statement of the annual revenue of the Priory of Selborne, whieh is therein estimated ut 160 flor, auri; whereas Bishep Godwin sets it at 337l. 15s.61 d. Now a floren, so named, says Camden, beeause made by Florentines, was a gold eoin of King Edward III. in value 6s. whereof 160 is not one-seventh part of $337 l$. 15s. 6td.

VOL. II.

HI II 
date the 8th day of June, in the year of our Lord 1486, and in the second year of his pontificate, confirmed what had been done, and suppressed the convent.

Thus fell the considerable and well endowed Priory of Selborne after it had subsisted about two hundred and fifty-four years; about seventy-four years after the suppression of Priories alien by Henry V., and about fifty years before the general dissolution of monasteries by Henry VIII. The founder, it is probable, had fondly imagined that the sacredness of the institution, and the pious motives on which it was established, night have preserved it inviolate to the end of time-yet it fell,

"To teach us that God attributes to place

No sanctity, if none be thither brought

By men who there frequent, or therein dwell."

Miltow's " Paradise Lost."

\section{LETTER XXY.}

WAINFLEET did not long enjoy the satisfaction arising from this new aequisition; but departed this life in a few months after he had effected the union of the Priory with his late founded college; and was sueceeded in the see of Winchester by Peter Courtney, some time towards the end of the year 1486 .

In the beginning of the following year the new bishop released the president and fellows of Magdalen College from all actions respecting the Priory of Selborne; and the prior and convent of St. Swithin, as the chapter of Winchester eathedral, confirmed the release. ${ }^{1}$

N. 293. "Relaxatio Petri $\overline{\text { epi }}$ Wintōn Ricardo Mayew, Presidenti omnium actionum oceasione indempnitatis sibi debite pro unione Prioratus de Selborne dieto eollegio. Jan. 2. 1487. et translat. anno $1^{\circ}$."

N. 374. "Relaxatio prioris et conventus $\mathrm{S}^{t_{\mathrm{i}}}$ Swithini Wiutōn confirmans relaxationem Petri $\overline{\mathrm{ep}}$. Winton." 1487. Janı. 13.

1 The bishops of Winchester were patrons of the Priory. 
Ashforde, the deposed prior, who had appeared as an evidence for the impropriation of the Priory at the age of seventy-two years, that he might not be destitute of a maintenance, was pensioned by the cullege to the day of his death; and was living on till 1490 , as appears by his acquittances.

ReG. A. ff. 46 .

"Omnibus Christi fidelibus ad quos presens scriptum pervenerit, Richardus Mnyew, presidens, \&c. et scolares, salutem in Domino.

"Noveritis nos prefatos presidentem et scolares dedisse, concessisse, et hoc presenti scripto confirmasse Thome Ashforde, capellano, quendam annualem redditum sex librarum tresdecim solidorum et quatuor denariorum bone et legalis monete Anglie - ad terninum vite prefati Thome "- to be paid from the jossessions of the college in Basingstoke.- "In eujus rei testimonium sigillum nostrum commune presentibus apponimus. Dat. Oxon. in coll. nostro supra dicto prinso die mensis Junii anno regris Ricardi tertii secundo, viz. 1484. The college, in their grant to Ashforde, style him only capellenus; but the annuitant very naturally, and with a becoming dignity, asserts his late title in his aequittanees, and identifies himself by the addition of nuper priorem, or late prior.

As, according to the persuasion of the times, the depriving the founder and benefactors of the Priory of their masses and services would have been deemed the most impious of frauds, Bishop Wainfleet, having by statute ordained four obits for himself to be eelebrated in the chapel of Magdalen College, enjoined in one of them a special collect for the anniversary of Peter de Rupibus, with a particular prayer-" Deus Indulgentiarum."

The college also sent Nicholas Langrish, who had been a chantry priest at Selborne, to celebrate mass for the souls of all that had been benefactors to the said Priory and college, and for all the faithful who had departed this life.

N. 356. Thomas Kuowles, presidens, \&c.-“ damus et con- 
[LETT.

cedimus Nicholao Langrish quandum capellaniam, vel salarium, sive alio quocunque nomine censeatur, in prioratu quondam de Selborne pro termino 40 annorum, si tam diu vixerit. Ubi dictis magr. Nicholaus celebrabit pro animabus omnium benefactorum dicti prioratus et coll. nostri, et omnium fidelium defunctorum. Insuper nos, \&c. concedimus eidem ibidem celebranti in sustentationem suam quandam annualem pensionem sive annuitatem octo librarum, \&c.-in dicta capella dicti prioratus - concedirnus duas cameras contiguas ex parte boreali dicte capelle, cum una coquina, et cum uno stabulo conveniente pro tribus equis, cum pomerio eidem adjacente voc. le OrcheyardPreterea 26s. 8d. per ann. ad inveniendum unum clericum ad serviendum sibi ad altare, et aliis negotiis necessariis ejus."-His wood to be granted him by the president on the progress.--He was not to absent himself beyond a certain time; and was to superintend the coppices, wood, and hedges.- "Dat. 5\%. die Julii. anº. Hen. VIII" ${ }^{\mathrm{vI}}$. 360." [viz. 1546.]

Here we see the Priory in a new light, reduced as it were to the state of a chantry, without prior and without canons, and attended only by a priest, who was also a sort of bailiff or woodman, his assistant clerk, and his female cook. Owen Oglethorpe, president, and Magd. Coll. in the fourth year of Edward VI. viz. 1551, granted an annuity of ten pounds a year for life to Nich. Langrish, who, from the preamble, appears then to have been fellow of that society: but, being now superannuated for business, this pension is granted him for thirty years, if he should live so long. It is said of him-" cum jam sit provectioris etatis quam ut," \&c.

Laurence Stubb, president of Magd. Coll. leased out the Priory lands to John Sharp, husbandman, for the term of twenty years, as early as the seventeenth year of Henry VIII.-viz. 1526: and it appears that Henry Newlyn had been in possession of a lease before, probably towards the end of the reign of Henry VII. Sharp's rent was vili. per annum.-Regist. B. p. 43.

By an abstract from a lease lying before me, it appears that Sharp found a house, two barns, a stable, and a duf-house [dovehouse], built, and standing on the south side of the old Priory, 
and late in the occupation of Newlyn. In this abstract also are to be seen the names of all the fields, many of which continue the same to this day. ${ }^{1}$ Of some of them I shall take notice where anything singular occurs.

And here first we meet with Paradyss [Paradise] Mede. Every convent had its Paradise; which probably was an enclosed orchard, pleasantly laid out, and planted with fruit trees. Tylehouse Grove, so distinguished from having a tiled house near it. ${ }^{2}$ Butt-wood Close; here the servants of the Priory and the village swains exercised themselves with their long bows, and shot at a mark against a butt, or bank. ${ }^{3}$ Cundyth [conduit] Wood: the engrosser of the lease not understanding this name has made a strange barbarous word of it. Conduit Wood was and is a steep rough cow-pasture, lying atbove the Priory, at about a quarter of a mile to the south-west. In the side of this field there is a spring of water that never fails; at the head of which a cistern was built which communicated with leaden pipes that conveyed water to the monastery. When this reservoir was first constructed does not appear, we only know that it underwent a repair in the episcopate of Bishop Wainfleet, about the year $1462 .^{4} \quad$ Whether these pipes only conveyed the water to the Priory for common and culinary pur-

1 It may not be amiss to mention bere that various names of tithings, farms, fields, woods, \&c. which appear in the ancient deeds, and evidences of several centuries standing. are still preserved in common use with little or 10 variation :-as Norton, Southington, Durton, Achangre, Blackmore, Bradshot, Rood, Plestor, \&c., \&c. At the same tine it should be acknowledged that other places have entirely lost their original titles, as Le Buri and Truestede in this village; and La Liega, or La Lyge, which was the name of the original site of the Priory, \&c.

2 Men at first heaped sods, or fern, or heath, on their roofs to keep off the inclemencies of the weather : and then by degrees laid straw or haum. The first refinements on roofing were shingles, which are very ancient. Tiles are a very late and imperfect covering, and wore not much in use till the beginning of the sixteenth century. The first tiled house at Nottingham was in 1503 .

3 There is also a Butt-close just at the back of the village.

N. 381. "Clausure terre abbatie ecclesie parochiali de Seleburne, ix:. iiiid. Reparacionibus domorum predicti prioratus iiii. lib xis. Aque conduct. ibidem. xxiiid. 
poses, or contributed to any matters of ornament and elegance, we shall not pretend to say; nor when artists and mechanics first understood anything of hydraulics, and that water confined in tubes would rise to its original level. There is a person now living who had been employed formerly in digging for these pipes, and once discovered several yards, which they sold for old learl.

There was also a plot of ground called Tan House Garden: and "Tannaria sua," a tan-yard of their own, has been mentioned in Ietter XVI. This circumstance I just take notice of, as an instance that monasteries had trades and oceupations carried on within themselves. ${ }^{2}$

Registr. P. pag. 112. Here we find a lease of the parsonage of Selborne to Thomas Sylvester and Miles Arnold, husbandmen - of the tythes of all manner of corne pertaining to the parsonage-with the offerings at the chapel of Whaddon, belonging to the said parsonage. Wat. June 1. $27^{\text {th }}$. Hen. $8^{\text {th }}$. [viz. 1536.]

As the chapel of Whaddon has never been mentioned till now, and as it is not noticed by Bishop Tanner in his "Notitia Monastica," some more particular acconnt of it will be proper in this place. Whaddon was a chapel of ease to the mother chureh of Selborne, and was situated in the tithing of Oakhanger, at about two miles distance from the village. The farm and field whereon it stood are still called Chapel Famn and Field :2 but there are no remains or traces of the building itself, the very foundations having been destroyed before the memory of man. In a farm yard at Oaklianger we remember a large hollow stone of a close substance, which had been used as a hog-trongh, but was then broken. This stone, tradition said, had been the baptismal font of Whaddon chapel. The chapel had been in a very ruinous state in old days; but was new-built at the instance of Bishop Wainfleet, about the year 1463, during the first priorship of Berne, in consequence of a sequestration issued forth by that

3 There is still a wood near the Priory, called Tanner's Wood.

2 This is a manor-farm, at present the property of Lord Stawell; and belonged probably in ancient times to $\mathrm{J}_{0}$. de Venur, or Venuz, one of the first benefactors to the Priory. 
visitor against the Priory on account of notorious and shameful dilapidations. ${ }^{1}$

The Selborne rivulet becomes of some breadtl at Oakhanger, and, in very wet seasons, swells to a large flood. There is a bridge over the stream at this lamlet of considerable antiquity and peculiar sliape, known by the name of Tunbridge: it consists of one single blunt Gotlic arch, so ligh and sharp as to render the passage not very convenient or safe. Here was also, we find, a bridge in very early times; for Jacobus de Hochangre, the first benefactor to the Priory of Selborne, held lis estate at Hochangre by the service of providing the king one foot soldier for forty days, and by building this bridge. "Jacobus de Hochangre tenet Hochangre in com. Soutlampton, per Serjantiam, ${ }^{2}$ inveniendi unum valectum in exereitu Domini regis [seil. Henrici $I I I^{\mathrm{tii}}$.] per 40 dies; et ad faciendum pontem de Hochangre: et valet per anu. C. s."-Blount's Ancicnt Tonurcs, p. 84 .

A dore-liouse was a constant appendant to a manorial dwelling: of this convenience more will be said hereafter.

A corn-nill was also esteemed a necessary appendage of every manor; and therefore was to be expected of course at the Priony of Selborne.

The prior had secta molendini, or ad molendinum :3 a power of compelling his vassals to bring their coru to be ground at his mill, according to old eustom. He had also, according to Bishop Tanner, sccte molendini de Strete: but the purport of Strete, we must confess, we do not unclerstand. Strete, in old Englisl, signifies a rond or lightray, as Watling Strete, \&c. therefore the prior might have some mill on a ligh road. The Priory had only one mill originally at Selborne; but by grants of lands, it becane possessed of one at Durton, and one at Oaklianger, and

'See Letter XIX. of these Antiquities. - "Summa total, solut." de novis edificationibus, et reparacionibus per idem tempus, nt pitet per comput."

"Videlicet de nova edificat. Capelle Marie de Wadden. xiiii lib. v s. viii ، - Reparacionibus ecclesie Prioratus, cancellor. et eapellar. ecelesiarum et capellarum de Selborne, et Estworhlam." - \&e. \&e.

" Sargentia, a sort of tenure of doing something for the king.

3 "Servitium, quo feudatorii grana sua ad Domini molendinum, ibi molenda perferre, ex consuetudine, astringuntur." 
probably some on its other several manors. ${ }^{1}$ The mill at the Priory was in use within the memory of man, and the ruins of the mill-house were standing within these thirty years: the pond and dam, and miller's dwelling, still remain. As the stream was. apt to fail in very dry surnmers, the tenants found their situation very distressing, for want of water, and so were forced to abandon the spot. This inconvenience was probably never felt in old times, when the whole district was nothing but woodlands: and yet several centuries ago there seem to have been two or three mills between Well-head and the Priory. For the reason of this assertion, see Letter XXIX. to Mr. Barrington.

Occasional mention has been marle of the many privileges and immunities enjoyed by the convent and its priors; but a more particular statement seems to be necessary. The author therefore thinks this the proper place, and before he concludes these antiquities, to introduce all that has been collected by the judicious Bishop Tanner, respecting the Priory and its advantages, in his "Notitia Monastica," a book now seldom seen, on account of the extravagance of its price; and being but in a few hands cannot be easily consulted. ${ }^{2}$ He also alds a few of its many privileges from other authorities:-the account is as follows (Tanner, page 166):-

\section{SELEBURNE.}

A Priory of black canons, founded by the often-mentioned Peter de Rupibus, Bishop of Winchester, A.D. 1233, and dedicated to the Blessed Virgin Mary: but was suppressed-and granted to Williain Wainfleet, Bishop of Winchester, who made it part of the eudowment of St. Mary Magdalen College in Oxford. The Bishops of Winchester were patrons of it. [Pat. 17.

${ }^{1}$ Thomas Knowles, president, \&c. unn. Hen. 8vi xxiii. ${ }^{\circ}$ [viz. 1532.] demised to J. Whitelie their mills, \&c. for twenty years. Rent xxiiis. iiiid.--Accepted Frewen, president, \&c. ann. Caroli xv. [viz. 1640.] demised to Jo. Hook and Elizabeth, his wife, the said mills. Rent as above.

2 A few days after this was written a new edition of this valuable work was announced, in the month of April of the year 1787, as published by Mr. Nasmith. 
Edw. II.]-Vide in Mon. Angl. tom. ii. p. 343. "Cartam fundationis ex ipso autographo in archivis Coll. Magd. Oxōn. ubi. etiam conservata sunt registra, cartæ, rentalia et alia munimenta ad hunc prioratum spectantia.

"Extracta quædam e registro MSS. in Bibl. Bodl.-Dodsworth, vol. 89. f. 140."

"Cart. antiq. N. N. n. 33. P. P. n. 48. et 71. Q. Q. 11. 40. plac. coram justit. itin. [Southampton] $20 \mathrm{Hen}$. rot. 25. De eccl. de Basing, \& Basingstoke. Plac. de juratis apud Winton. 40 Herı. III. rot.-Prosecta molendini de Strete. Cart. 54. Hen. III. m. 3. [De mercatu, \& feria apud Seleborne, a mistake.] Pat. 9. Edw. I. m.-Pat 30. Edw. I. m. Pat. 33. Edw. I. p. 1.m-Pat. 35. Edw. I. m.-Pat. 1. Edw. II. p. 1. m. 9. Pat. 5. Edw. II. p. 1. m. 21. De terris in Achanger. Pat. 6. Edw. II. p. 1. m. 7. de eisdem. Brev. in Seacc. 6 Edw. II. Pasch. rot. 8. Pat. 17. Edw. II. p. 1. m.-Cart. 10. Edw. III. n. 24. Quod terræ sue in Seleburn, Achangre, Norton, Basings, Basingstoke, and Nately, sint de afforestatæ, and pro aliis libertatibus. Pat. 12. Edw. III. p. 3. m. 3.-Pat. 13. Edw. III. p. 1. m.-Cart. 18. Edw. III. 12. 24."

"N. N. 33. Rex concessit quod prior, et canonici de Seleburn habeant per terras suas de Seleburne, Acliangre, Norton, Brompden, Basinges, Basingstoke, \& Nately, diversas libertates.

"P. P. 48. Quod prior de Seleburne, habeat terras suas quietas de vasto, et regardo."-Extracts from Ayloffe's Calendars of Ancient Charters.

"Placita de juratis \& assis coram Salōm de Roff, \& sociis suis justic. itiner. apud Wynton in comitatu Sutht.-anno regni R. Edvardi filii reg. Henr. octavo.-Et Por de Seleborn lit in Selebr. fure. thurset. pillory, emendasse panis, \& suis." [cerevisize.] -Chapter House, Westminster.

"Placita Foreste apud Wyntōn in com. Sutham.-Anno reg. Edwardi octavo coram Rog. de Clifford.—\&c. Justic. ad eadem placita audienda et tminand. assigtis.

"Carta P'ror de Seleburn, II. Dei gra. rex. angl. \&c. Coucessin. prior. sce. Marie de Seleburn. et canouicis ibidem Deu servient. . . . . q q ipi et oes hoies sui in pdeis terri suis et tenementis manentes sint in ppetum quieti de sectis SwaneVOL. II. 
[LETT.

motor. et omnium alior. placitor. for. et de espeltumentis canum. et de omnibus submonitoibz. placitis querelis et exaccoibus et occoibz. ad for. et for. et viridar. et eor. ministros ptinentibz." Chapter House, Westminster.

"Plita Forestarum in com. Sutht. apud Suthamton ...... anno regni regis Edwardi tcii post conquestum quarto coram Tohe Mantvers. \&c. justic. itinand \&c.

"De hiis qui clamant libtates infra Forestas in com. Sutht.

"Prior de Selebourne clamat esse quietus erga d $\overline{n ! n}$ regem cle omnibus finibus et amerciamentis p tnsgr. et omnibus exaccoibz ad Dom. regem vel hered. suos ptinent, pret. plita corone reg.

"Item clamat $q^{d}$ si aliquis hominum suorum de terris. et ten. p. delicto suo vitam aut membrum debeat amittere vel fugiat, $\&$ judico stare noluerit vel aliud delictum fecit pro quo debeat catella sua amittere, ubicunq; justitia fieri debeat omnia catella illa sint ptci Prioris et successor. suor. Et liceat eidem priori et ballis suis ponere se in seisinam in hujusmodi catall. in

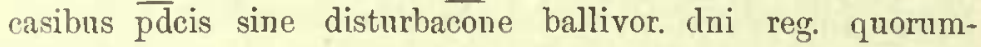
enuque.

"Item clam. quod licet aliqua lib̆tatum $p$ dün regem concessar. pcessu temporis quocunq; casu contingente usi non fuerint, nlominus postea eadm libtate uti possit. lit pdcus prior quesitus p justic. quo waranto clamat omn. tcrr. et. ten. sua in Seleburne, Norton, Basynges, Basyngestoke, \& Nattele, que prior domus pdte huit \& tenuit $X^{\text {mo }}$. die April anno regni $\overline{\text { dni }}$ Hen. reg. pavi dni reg. nue XVIII. imppm esse quieta de vastro et regardo, et visu forestarior. et viridarior regardator. et omnium ministrorum foreste." \&c. \&c.-Chapter House, Westminster."

\section{LETTER XXVI.}

Thovgr the evidences and documents of the Priory and parish of Selborne are now at an end, yet, as the author has still several things to say respecting the present state of that convent and "its Grange, and other matters, he does not sec how he can 
acquit himself of the subject without trespassing again on the patience of the reader by adding one supplementary letter.

No sooner did the Priory (perhaps much out of repair at the time) become an appendage to the college, but it must at once have tended to swift decay. Magdalen College wanted now only two chambers for the chantry priest and his assistant; and therefore had no occasion for the hall, dormitory, and other spacious apartments belonging to so large a foundation. The roofs neglected, would soon become the possession of daws and owls; and, being rotted and decayed by the weather, would fall in upon the floors; so that all parts must have hastened to speedy dilapidation and a scene of hroken ruius. Three full centuries have now passed since the dissolution; a series of years that would craze the stoutest edifices. But, besides the slow hand of time, many circumstances have contributed to level this venerable structure with the ground; of which nothing now remains but one piece of a wall of about ten feet long, and as many feet high, which probably was part of an out-house. As early as the latter end of the reign of Hen. VII. we fincl that a farm-house and two barns were built to the south of the Priory, and uncloubtedly out of its materials. Avarice, again, has much contributed to the overthrow of this stately pile, as long as the tenants could make money of its stones or timbers. Wantonness, no doubt, has had a share in the demolition; for boys love to clestroy what men veuerate and admire. A remarkable instance of this propensity the writer can give from his own knowledge. When a schoolboy, more than fifty years ago, he was eyewitness, perhaps a party concerned, in the undermining a portion of that fine old ruin at the north end of Basingstoke town, well known by the name of Holy Ghost Chapel. Very providentially the vast fragment, which these thoughtless little engineers endeavoured to sap, did not give way so soon as might have been expected; but it fell the night following, and with such violenee that it slook the very ground, and, awakening the inhabitants of the neighbouring cottages, made them start up in their beds as if they had felt an enrthquake. The motive for this dangerous attempt does not so readily appear: perhaps the nore danger the more honour, 
thought the boys; and the notion of doing some mischief gave a zest to the enterprise. As Dryden says upon another occasion-

"It look'd so like a sin it pleased the more."

Had the Priory been only levelled to the surface of the ground, the discerning eye of an antiquary might have ascertained its ichnography, and some judicious hand might have developed its dimensions. But, beside other ravages, the very foundations have been torn up for the repair of the highwnys: "so that the site of this convent is now become a rough, rugged pasture-field, full of hillocks and pits, choked with nettles, and dwarf-elder, and trampled by the feet of the ox and the heifer.

As the tenant at the l'riory was lately digging among the foundations, for materials to mend the highways, his labourers discovered two large stones, with which the farmer was so pleased that he ordered them to be taken out whole. One of these proved to be a large Doric capital, worked in good taste; and the other a base of a pillar; both formed out of the soft freestone of this district. These ornaments, from their dimensions, seem to have belonged to massive columns; and show that the church of this convent was a large and costly edifice. They were found in the space which has always been supposed to have contained the south transept of the Priory church. Some fragments of large pilasters were also found at the same time. The diameter of the capital was two feet three inches and a half; and of the column, where it had stood on the base, eighteen inches and three quarters.

Two years ago some labourers digging again among the ruins found a sort of rude thick vase or urn of soft stone, containing alsout two gallons in measure, on the verge of the brook, in the very spot which tradition has always pointed out as having been the site of the convent kitchen. This clumsy utensil, ${ }^{1}$ whether intended for holy water, or whatever purpose, we were going to

1 A judicious antiquary, who saw this vase, observed, that it possibly might have been a standard measure between the monastery and its tenants. The Priory we have mentioned claimed the assize of bread and beer in Selborne unnor : and probably the adjustment of dry measures for grain, \&c. 
procure, but found that the labourers had just broken it in pieces, and carried it out on the highways.

The Priory oî Selborne had possessed in this village a Grange, a usual appendage to mannrial estates, where the fruits of their lands were stowed and laid up for use, at a time when men took the natural produce of their estates in kind. The mansion of this spot is still called the Grange, and is the manor-house of the convent possessions in this place. The author has conversed with very ancient people who remembered the old original Grange; but it has long given place to a modern farm-house. Magdalen College holds a eourt-leet and court-baron ${ }^{2}$ in the great wheat-barn of the said Grange, annually, where the president usually superintends, attended by the bursar and steward of the college. ${ }^{2}$

The following uncommon presentment at the eourt is not unworthy of notice. There is on the south side of the king's field (a large common field so called) a considerable tumulus, or' hillock, now covered with thorns and bushes, and known by the name of Kite's Hill, which is presented, year by year, in court as not ploughed. Why this injunction is still kept up respecting this spot, which is surrounded on all sides by arable land, nay be a question not easily solved, since the usage has long survived the knowledge of the intention thereof. We can only suppose that as the prior, besides thurset and pillory, had also furcas, a power of life and death, that he might have reserved this little eminence as the place of execution for delinquents. And there is the more reason to suppose so, sinee a spot just by is called Gally [Gallows] Hill.

The lower part of the village next the Grange, in which is a pond and a strean, is well known by the name of Gracions Street, an appellation not at all understood. There is a lake in Surrey, near Chobham, called also Gracious Pond : and another, if we mistake not, near Hedleigh, in the eounty of Hants. This

1 The time when this court is held is the mid-week between Easter and Whitsuntide.

2 Owen Oglethorp, president, \&c. an. Edw. Sexti, primo [viz. 1547.] demised to Robert Arden, Selborne Grange, for twenty years. Rent $\mathbf{v}^{14}$.-Index of Lenses. 
strange denomination we do not at all comprehend, and conclude that it may be a corruption from some Saxoll word, itself perhaps forgotten.

It has been observed already, that Bishop Tanner was mistaken when he refers to an evidence of Dodsworth, "De mereatu et FERIA de Seleburne." Selborne never had a chartered fair; the present fair was set up since the year 1681, by a set of jovial fellows, who had found in an old almanac that there had been a fair here in former days on the 1st of Angust; and were desirous to revive so joyous a festival. Against this innovation the vicar set his face, and persisted in crying it down, as the probable occasion of much intemperance. However the fair prevailed; but was altered to the 29th of May, because the former day often interfered with wheat harvest. On that day it still continues to be held, and is become a useful rnart for cows and calves. Most of the lower housekeepers brew beer against this holiday, which is dutied by the exciseman; and their becoming victuallers for the day without a licence is overlooked.

Monasteries enjoyed all sorts of conveniences within themselves. Thus at the Priory, a low and moist situation, there were ponds and stews for their fish : at the same place also, and at the Grange in Culver Croft, there were dove-houses; and on the hill opposite to the Grange the prior had a warren, as the names of The Coney Crofts and Coney Croft Hanger plainly testify. $^{2}$

Nothing has been said as yet respecting the tenure or holding of the Selborne estates. Temple and Norton are manor farms and freehold; as is the manor of Chapel near Oakhanger, and also the estate at Oakhanger House and Blackmoor. The Priory and Grange are leasehold under Magdalen College, for twenty-one years, renewable every seven: all the smaller estates in and round the village are copyhold of inheritance under the college, except the little remains of the Gurdon manor, which had been of old leased ont upon lives, but liave been freed of late by their present lord, as fast as those lives have dropped.

1 Culver, as has been observed before, is Saxon for a pigeon.

- A warren was a usual appendage to a manor. 
Selborne seems to have derived much of its prosperity from the near neighbourhood of the Priory. For monasteries were of considerable advantage to places where they had their sites and estates, hy causing great resort, by procuring markets and fairs, by freeing them from the cruel oppression of forest-laws, and by letting their lands at easy rates. But, as soon as the convent was suppressed, the town which it had occasioned began to decline, and the market was less frequented; the rough and sequestercd situation gave a check to resort, and the neglected roads rendered it less and less accessible.

That it had been a considerable place for size formerly appears from the largeness of the cliurch, which much exceeds those of the neighbouring villages; by the ancient extent of the burying ground, which, from human bones occasionally dug up, is found to have been much encroached upon; by giving a name to the hundred; by the old fonndations and ornamented stones and tracery of windows that have been discovered on the north-east side of the village; and by the many vestiges of disused fish-ponds still to be seen around it. For ponds and stews were inultiplied in the times of popery, that the affluent might enjoy some variety at their tables on fast days; therefore the more they abounded the better probably was the condition of the inhabitants. 


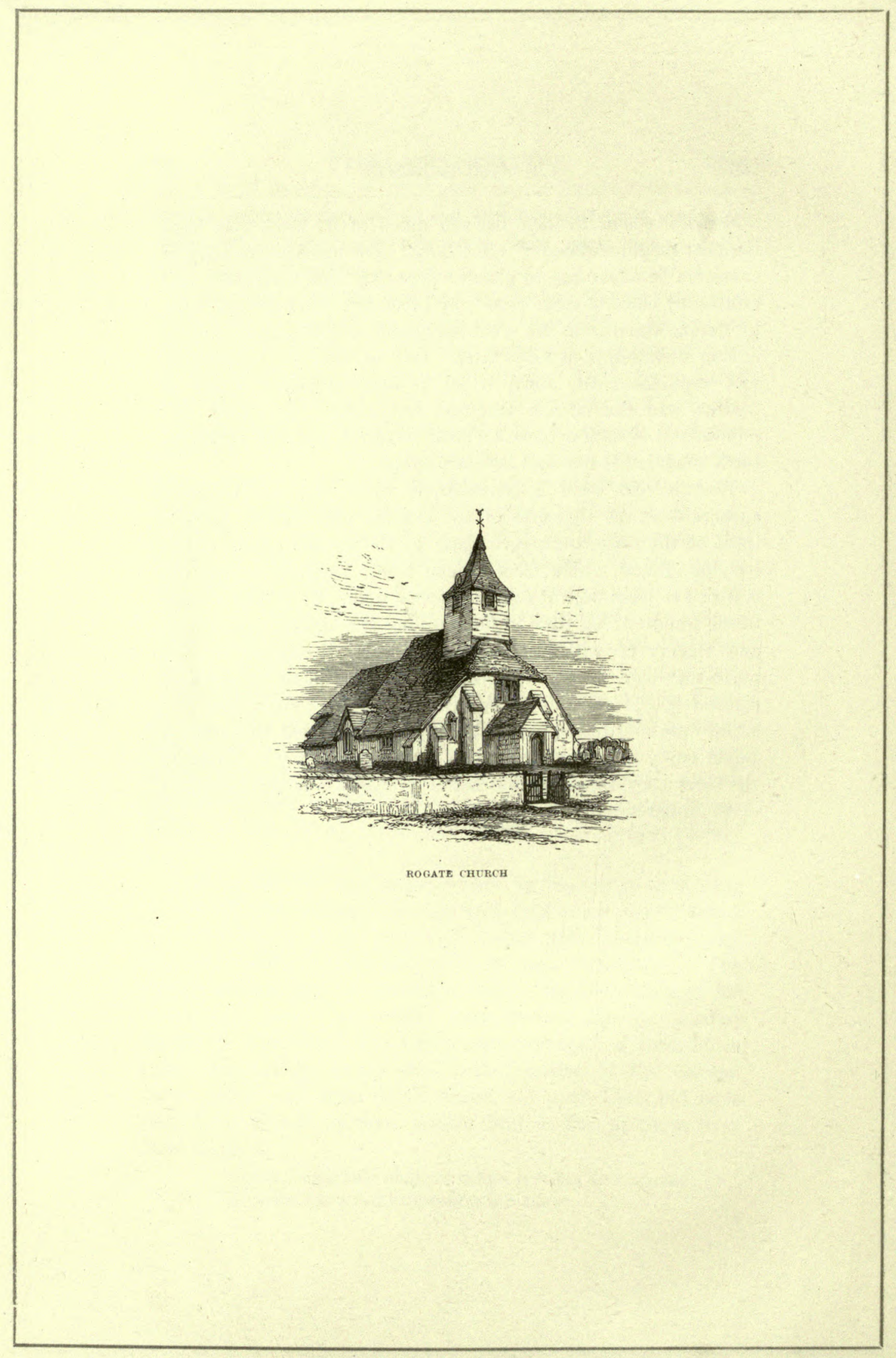




\section{APPENDIX}

ON THE

\section{ROMAN-BRITISH ANTIQUITIES \\ OF SELBORNE.}

VOL. II.

K K 


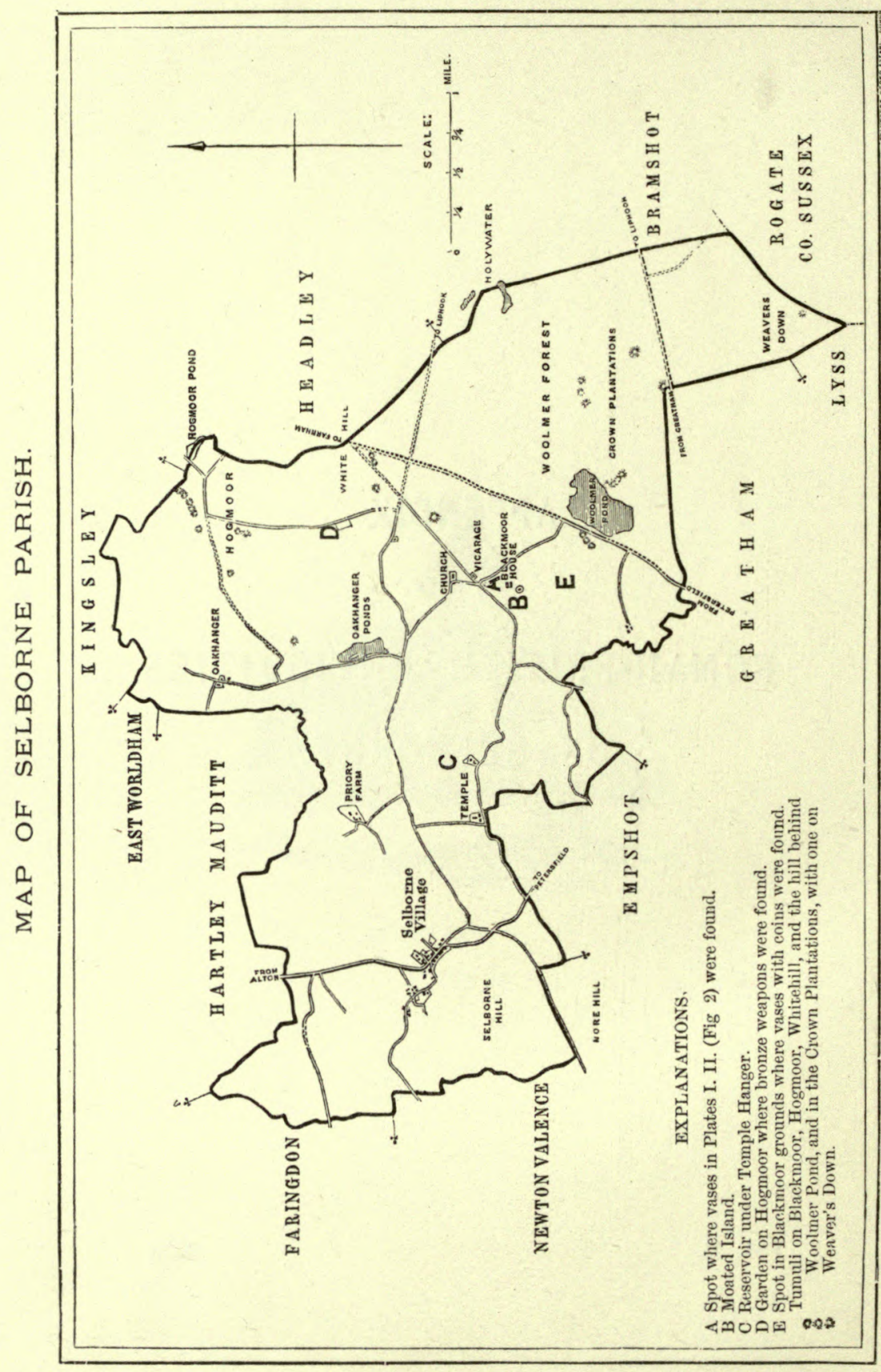




\title{
A P P E N D I X.
}

\author{
BY LORD SELBORNE.
}

THE conclusion, drawn by White from the discovery of lioman coins during the first half of the last century in the bed of Woolmer Pond, that Selborne was not unknown to the Romans ("Antiquities," p. 1), has been abundantly confirmed by other and more recent discoveries.

About the year 1774, (as appears by a letter dated in Angust 1777, from Mr. Sewell, then residing at Headley, to Mr. White, for the communication of which I am indebted to the kindness of Professor Bell,) a large pot of coins or medals was also found in Woolmer Pond, from which Mr. Sewell obtained a complete series of all the Roman Emperors, from Claudius the First to Commodus (both inclusive), and the two Fanstinas, and Crispina, the wife of Commodus, extending over nearly 150 years, from A.D. 43 to A.D. 194. There were none, he says, later than Commodus. And I learn from Mr. Prettejohn (now residing at Yanston in Devonshire), who lived for more than thirty years near Woolmer Pond, and was "foreman" of the Forest for a period including the reign of George the Fourth, that in his.time lioman coins were occasionally found in the gravel and sand of Woolmer Pond, on the Blackmoor side, and sometimes also in the old roads and paths in the open Forest, and within the present grounds of Blackmoor House. He limself, and other members of his family, have found more than twenty, amoug the siftings of gravel, dug to repair the turnpike road by the side of the pond; four of which (being all that he has 
retained) he has had the goodness to show me. They are much defaced, and the legends are wholly obliterated : but one can be recognized as of the younger Faustina, and one as of Crispina, the Empress of Commodus.

In 1865, having purchased the Temple and Blackmoor estates, I chose for my residence the spot then occupied by Blackmoor Farm House, the position of which is shown by the words "Blackmoor House," on the accompanying map. The name "Blackmoor" properly belongs to the western and northern parts of the sandy ridges (raised considerably above the lower level of Woolmer Forest, and themselves overlooked from the west by the escarpments of the upper green-sand and the still loftier chalk summits behind them) by which the basin of Woolmer Forest, where it is crossed by the main road between Petersfield and Farnham, is inclosed. To the north-east and east, the ridges of Blackmoor connect themselves with those of Hogmoor, Whitehill, and Wall-Down; between which and the soutleastern and southern ridges, dividing this forest basin from the valley traversed by the road between Greatham and Liphook (on which stand fir plantations belonging to the crown), rises the conspicuous landmark of Holy-Water (or Holly-Water) Clump. The intermediate low ground, covered with rough heather, and interspersed here and there with pools of water at certain seasons, is in breadth about a mile and a half from north to south, by about two miles in length from east to west. In a depression, at the narrowest point between the government plantations to the south-east and the most southerly part of the Plackmoor ridges, lies Woolmer Pond; a shallow lake, nearly always fordable by man or horse in every part, and varying with the seasons from a large and broad sheet of water to a bed of sand, almost entirely dry in times of prolonged drought.

All these ridges, and the basin below them, are upon the formation called by geologists the lower green-sand, which is naturally barren, or covered only with furze and heath, though now planted in many places, chiefly with Scotch fir. But the westerly ridge of Blackmoor extends back as far as the gault clay, on which there is abundance of oak and other wood. At 
the exact point of junction between these two formations, at the east end of Blackmoor Wood, and within the limits of the present gardens of Blackmoor House, is a small square island, surrounded by a moat of water; and behind, and higher than Blackmoor House, to the north (also included within the present gardens), is a piece of land formerly called the "Chapel Field." Here, at the spot marked $A$ on the map, while the foundations were being dug in 1867 for a kitclien-garden wall, the first discovery of Roman, or Roman-British, remains was made. A large sepulchral earthenware vase (Figure 2, Plate II.) was dug up, much broken in the upper part; in which were contained a small bronze cup, enamelled in varions colours (I'late I.), nearly perfect; and the remains of a bronze patera of extreme thinness, of which what seems to have been a handle is figured (No. 5) in Plate IV.; also one large bronze coin, much worn, which is pronounced by competent authority to be of Lucius Verus. There were in this vase some small remains of bones.

In other parts of the gardens and grounds, and in digging the foundations for the house and offices, there were found many fragments of various articles of Roman pottery, including some of Samian, or imitated fron Samian ware; some Roman tiles, many of which were in the island already mentioned, and seem to have belonged to flues for the passage of hot water or air; a brouze Celt or axe-head (Figure 1, Plate III.); a large leaden ring, such as might have been run through a staple fixed into a post or wall; and two iron axe-heads; an iron socket for receiving the head of an axe or other weapon; a large iron cattle-bell; and fragments of iron nails, \&c. The dates of these leaden and iron articles (all which were much oxidated) I do not profess to determine.

In 1868, the moat round the small island (marked B on the map) was cleaned out: and at the bottom of it were found a large earthenware water-vessel (Figure 1, Plate II.) and a small earthenware drinking-cup (Figure 3, Plate III.), both in excellent preservation.

A reservoir, for the storage of water, was constructed under the Temple "hanger," at the spot marked $\mathrm{C}$ on the map, in 
1869-1870; and in digging out this reservoir some further fragments of Roman pottery were found.

In the spring of 1870 , in the garden of a cottarge on the western side of the roud ascending from Eveley corner to Hogmoor, at the spot marked $D$ on the map, a number of bronze weapons, or parts of weapons (Roman or Roman-British), were found under peat, free from rust or oxidation. They consisted of twenty-seven fragments of sword blades, some of w]ich, when put together, made complete swords; two fragments of sword sheaths; one grooved socket for counecting a spear-head with the shaft; eighteen large, and six small, spearheads; two spear points; three rings; and two fragments of uncertain use. Most of the sword handles had bronze nails, evidently intended to fusten the iron part of the liandle to some covering material, remaining perfect in their holes; and in the cavities of several of the spear-heads the wooden points, which liad been inserted to fix them in sockets counecting the head with the shaft of the spear, were still remaining. Some of the edges of these weapons were hacked and notched, in a manner which could hardly have resulted from use; and of the sword blades, some had been forcibly bent, before being broken; proving that those who buried them had first taken pains to render them useless. Some of these fragments of swords are figured in Plate IV. (Figures 1, 2, 3, 4, with the section); two of the larger, and one of the smaller spear-heads, are figured (Nos. 7 and 8) in Plate IV.; the grooved socket is figured (No. 9) in the same Plate, with a section; the bronze rings are figured (No. 4) in Plate III.; and one of the fragments of uncertain use is figured (No. 10) in Plate IV.

In the same cottage garlen, there have also since been found, in a fragment of a small earthenware pot, nearly 100 copper coins, much defaced, chiefly of the elder Tetricus, but including a few of his son, and of Gallienus and Victorinus.

The next discovery was that of two large earthenware vases (Figure 2, Plate III. and Figure 5, Plate V.), which, when perfect, must have contained considerably more than 30,000 Roman and Roman-British coins, the number of those wlich still remained in them when found, or which were recovered by myself from the 


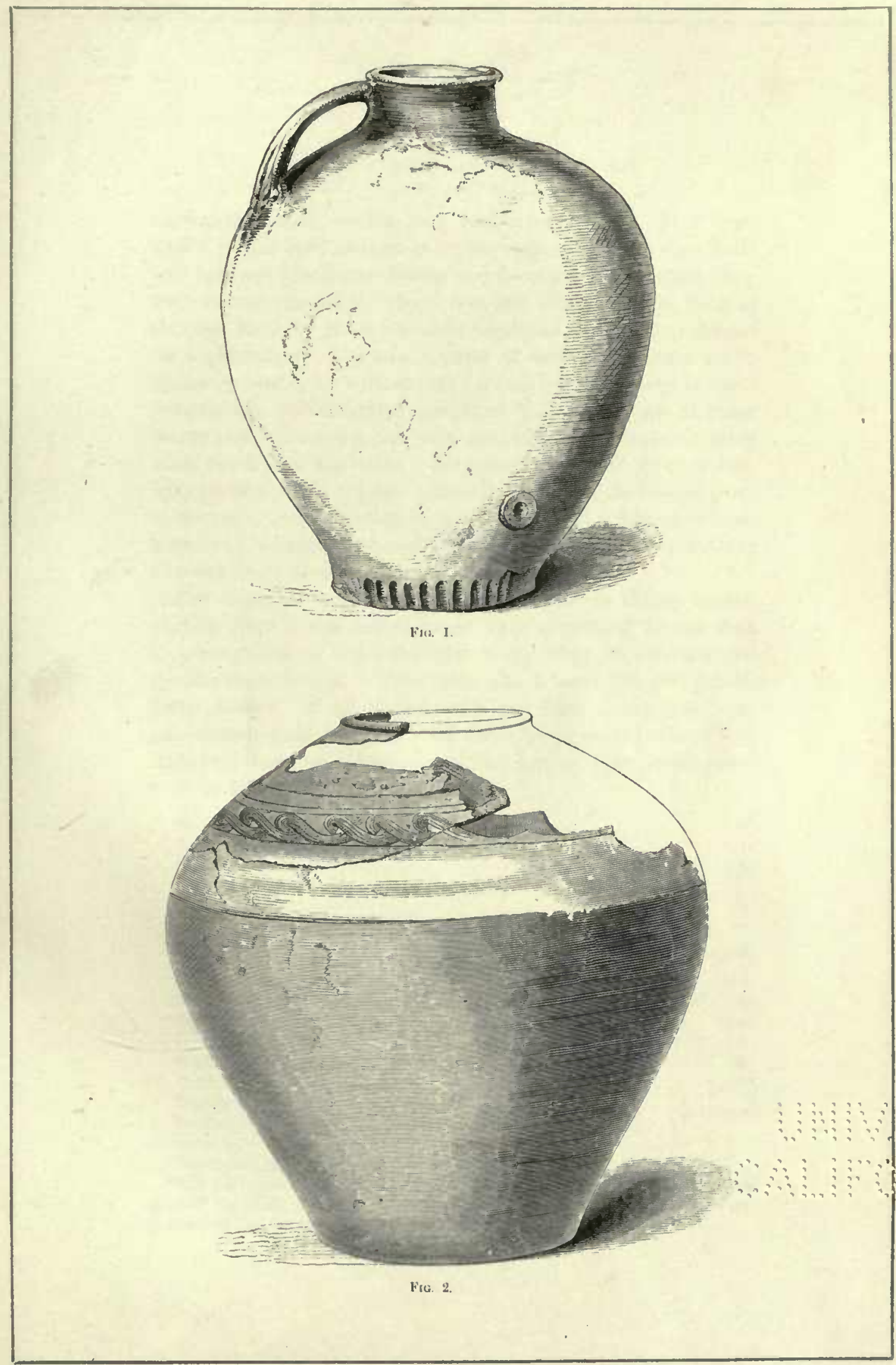

Waterk Vessir. ani) Large Selelchid Vase-(Blackmoor. 


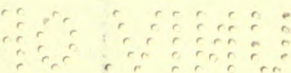

$\therefore \quad\left\{\begin{array}{lll}2 \\ \therefore\end{array}\right.$ 
surrounding earth, having been counted at 29,773 . They were buried at the spot marked $\mathbf{E}$ on the map, rather less than halfway between Blackmoor House and Woolmer Pond, where they were found, covered by about two feet of soil, on the 30th of October, 1873 , by some workmen employed in trenching ground for a plantation. The upper parts of both vases were much broken, probably by agricultural operations. The coins in them were closely caked together (see Plate V., showing part of those in one vase, after many had keen removed), and completely fillecl what was left of the vases. They were all coated, more or less, with green oxide of copper. Some fragments of the broken parts of the vases, and a small piece of the bottom of a Roman mortar, were soon afterwards found near the same spot; but nothing else was there discovered.

The coins, on examination, were found to be chiefly bronze, varying from a size rather larger than a shilling to less than sixpence, those of the same size being often of very unequal thickness and weight. There were also a large number, principally denarii, of or plated with the base metal called by numismatologists "billon." Of the whole quantity, about onethird only have been cleaned; 24,985 , having been sorted, prove to be as follows:-

Gordian the younger (emperor A. D. 238-244) . . . . . . . 2

Philip the Arabian (emperur A. D. 244-249) . . . . . . . . 1

Otaeilia (wife of Philip). . . . . . . . . . . . . . 1

Volusian (son and associate of Gallus, who was emperor A.D. $\quad 1$ $252-254)$. . . . . . . . . . . . . . . $\}$

Valerian (emperor A.D. 254-260) . . . . . . . . . . 25

Gallienus (son and associate of Valerian, and sole emperor from 3,209

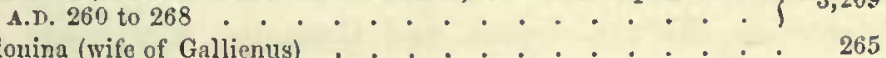

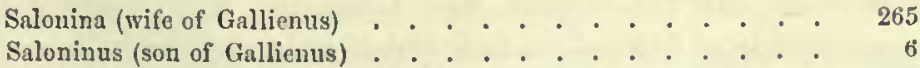

Postumus (Tyrant in Bitain and Gaul, A.1. 258-265). . . . . 294

Lrelianus (ditto, A.I. 265) . . . . . . . . . . . 8

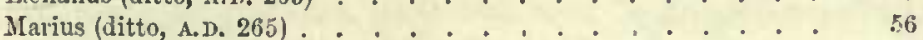

Vietorinus (ditto, A.卫 265-268) . . . . . . . . . 4,3051

Tetrieus Augustus (ditto, A.D. $268-271$ ) . . . . . . . $11,254^{2}$

Tetricus Casar (son of Tetricus Augustus)

1 There may be soine of Postumus (uneleaned) among those of Victorinus.

The uncleaned eoins of the younger Tetricus have not been separated from those of the elder. Of those wlich have been eleaned, the coins of the elder are to those of the younger in the proportion of 27 to 11 . 


\begin{tabular}{|c|c|c|c|c|c|c|c|c|}
\hline Claudius Gothicus (emperor A.D. 268 & $8-270)$ & & & & & & & 3,787 \\
\hline Ins (brother of Claudius, em & peror A.D. & $270)$ & & & . & . & & 691 \\
\hline emperor A.D. $270-275$ ) & . . . & & & . & . & . & & 164 \\
\hline vife of Aurelian). . & . & & & & . & & . & 14 \\
\hline acitus (emperor A.D. 275,276 ) & . . . & & & & . & & & 206 \\
\hline Florian (brother of Tacitus, emperor & A.D. 276 & & & & . & & & 22 \\
\hline nperor A. D. 276-282) & . . . & & & & . & & & 430 \\
\hline (.ग. 282,283$)$ & . . . & & & & . & & & 12 \\
\hline D. 282 ; emperor 2 & $283-285$ ) & & & & . & & & 24 \\
\hline and colleague of & Carinus) & & & & & & & 14 \\
\hline is) . &.$\quad$. & & & & & . & & \\
\hline $5-305)$ & . , . & & & & & & & 76 \\
\hline letian, & A.D. 286 & & & & & & & 53 \\
\hline 292 & 2 ; became & & & & & & & 1 \\
\hline A.D. 2 & $286-294)$ & & & & & . & & 502 \\
\hline $94-296)$ & . . & & & & & & & 82 \\
\hline
\end{tabular}

Among the coins which have been examined there are 110 (and doubtless there are many more among the rest) which must have cone from the mint in an imperfect state, some of them having either no heads or no reverses; some having a reverse on both sides; some twice struck, either with the head of the same prince, or with the liead of one prince on a coin previously bearing that of another. A large number $(4,767$ on the whole, most of them, apparently, of the commoner sorts) have been laid aside, as too much defaced to he capable of any satisfactory identification. In Plate V., two specimens of the coins of Carausius, one of Tacitus, and one of Diocletian, are engraved.

With respect to the condition of these coins, it is worth observation that those of Valerian, Gallienus, Salonina, Claudius, Victorinus, the two Tetrici, and Carausius, are generally the most worn and defaced-a fact which as to those of Carausius (almost the latest in the whole series) seeins remarkable. All the imperial coins of later date than Aurelian (as also those of Severina, and many of Aurelian himself), and all the coins of Allectus, are comparatively unworn and in fine condition, except when (as has happened in a few cases) they have sustained accidental damage, from excessive oxidation or adhesion while underground, or in the processes of separation

I Some coins of Quintillus may be among the uncleanch coins of Claudius. 


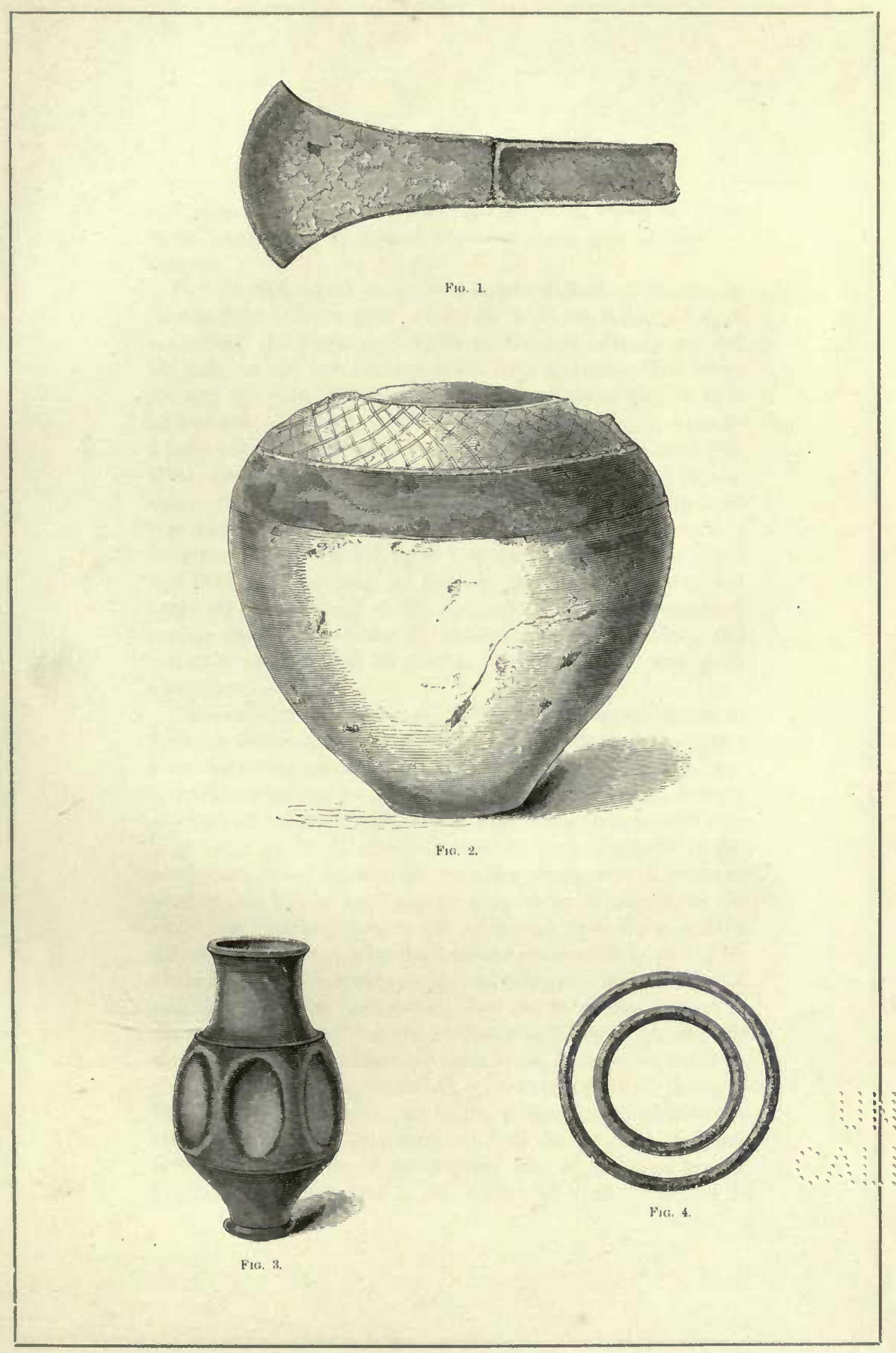

BROAZE ("HLT, VASE, C'P, ANI lisis,-(blackmoor.) 

and cleaning, In the legends and reverses, there is great variety, and some speeimens are rare, some may perhaps be unique.

This is understood to be the largest deposit of Roman or Roman-Britisls coins ever yet found in Great Britain; and it is rendered still more remarkable by the fact (already referred to), that, in the last century, other large quantities (the number has not been recorded) were found within a quarter of a mile of the same spot, in the bed of Woolmer Pond; some in a large pot, probably similar to the vases above mentioned, and others (being those mentioned by White) not inclosed in any vessel, but appearing to have been hastily thrown or poured into the water in a large heap or heaps. These appear to have been, if not wholly, in part at all events, of earlier date: and they were probably (at least in part) of greater size and value than those found at Blackmoor; for Mr. Sewell speaks of medals, and White speaks of medallions as well as coins; and describes those which he saw as having been in very good condition.

This account of the antiquities discovered in the parish of Selborne would be imperfect without adding that, on the ridges surrounding the forest basin, of which a description has been given, there are (as I reckon them) thirty-five circular tumuli, or sepulchral mounds, some larger than others, but none of very large size; of which eleven are on or near Hogmoor, to the north-east (seven together in one place, three near together in another, and one by itself apart); four are on Whitehill, to the east (three together, close to the ligh road, and one at a little distance apart); one is by itself on the south-easterly projection of the northern Blackmoor Ridge (the ridge on which the church and vicarage-honse now stand); five are in a line together at the southern extremity of the western Blackmoor Ridge (close by the high road, overlooking Woolmer Pond); six, close together, are at the top of the opposite hill, on the other side of Woolmer Pond; four, close together, are in the government fir plantations, about a quarter of a mile eastward from the east end of Woolmer l'ond; three are in the highest part of the same plantations, to the north-west of the high road from Greatham to VOL. II. 
Liplook (one apart from the others, to the soutli-west; the other two close together); and one, remote from all the rest, is on the summit ridge of Weaver's Down, close to the extreme southern boundary of Selborne parish. The positions of all these tumuli are marked on the map. Some of them appear to have been much, and all, or almost all of them, more or less disturbed: with what results I have no information, except what I have obtained from Mr. Prettejohn, who was present at the opening of five of them in 1829. He states that Mrs. Barlow, a lady then residing at Midhurst, by the permission of the proper authorities, caused that examination to be made. The first four mounds appeared to have been previously explored; and nothing was found in them, except piecos of charcoal, ashes, calcined bones, and (in one of them within the Brimstone Lodge inclosure) some small fragments of an urn, "old, rotten, decayed, crookey," and seeming to have been sum.dried, and not regularly burnt in a potter's kiln. In the fiftl (being the smaller of two upon "Cold-down Hill, not far from Hogmoor Pond and Binn's Pond"), an urn was found, placed on the original level of the ground, covered by a flot stone, and containing (as I infer), calcined human bones or ashes. Mr. Prettejohn describes it as "of a bilged shape, something between a pitcher and a flower-pot;" about eleven or twelve inches high, and capable of containing two or three quarts. It was "in appearance, weak;" lut it was, with care, sent off "by two men to Midhurst," (a distance of twelve miles) "carrying it on a sling on a pole." Mrs. Barlow supposed it to be not only a relic of muclı interest and value, but of antiquity far greater than Roman-British times: but a friend, learned in these subjects, whom I have consulted, is led, by the description given, to doubt the soundness of that opinion. No coins were found in any of the tumuli thus examined.

With respect to earlier explorations, all that I can gather, through the recollections of old inhabitants, is, that some of the tumuli on the Forest were opened by a gentleman named Butler, certainly not less than sixty years ago. I have myself lately opened the largest of those not covered by plantations on my owu property ; nothing, however, was found there, except traces 
PLATE II.

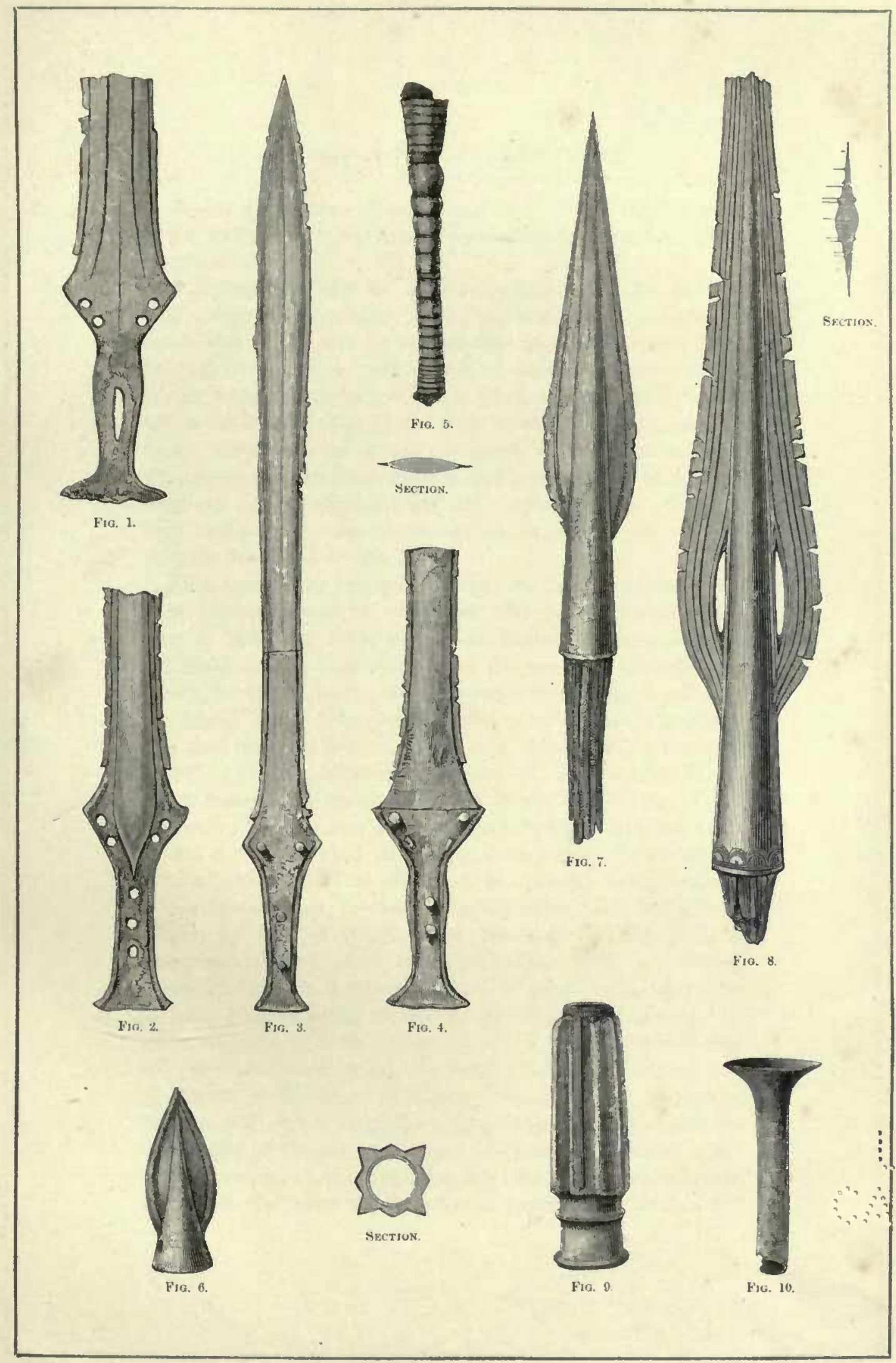

Swords and Swoht Handes, Speat Heads, Erc.-(Blackmoor.) 

of former disturbance of the ground down to the natural level, and a cavity, which might, not improbably, have once contained a sepulchral urn.

It occurs to me also to mention in this place (though their origin, nature, and purpose is obscure) that, immediately to the south-west of the five tumuli on the Blackmoor Ridge, overlooking Woolmer Pond, are a series of ancient parallel trenches (six or seven in number), of some depth, running nearly north and south from the top of the ridge down to the present high road. They are certainly not the result of natural or artificial drainage; and from their number and proximity to each other, they can hardly represcnt ancient tracks or ways. Whether they could, under any circumstances, have been intended for military defence, I do not know.

From the pottery and other remains found at and near Blackmoor House, it may be concluded with certainty that, on or close to that site, there once stood Roman or Roman-British buildings of some importance; and the name of the adjoining parish. Greatham, may perhaps indicate the situation (at least as early as Saxon times) of a hamlet or village more considerable than others in that neighbourliood. Mr. Sewell, in his letter of 1777, already referred to, speaks of lioman and British entrenchments, as visible at that time on Headley Heath and Common; and he also describes, as a known historical event (I know not on what authority), a march by Vespasian, as General under Claudius, about A.D. 47, from the neighbourhood of London towards Porchester, Southampton, and the Isle of Wight, by way of Headley and Woolmer; adding, that he (Vespasian) then fixed, at or near Woolmer Pond, "an abiding station or city, which remained near 150 years; when they seem to liave been expelled thence by the Britons, or perhaps by an earthquake, or some other cause." I have not myself niet with any mention of what Mír. Sewell calls "the Roman city or station of Wulmere in Hants," in any writer, ancient or modern, witl whose works I am acquainted; and it is possible (as the end of the period of "near 150 years," which he assigus for its continuance, coincides with the time of Commodus, whose coins were the latest which had been found in Woolmer Pond) 
that his statements, however historical in form, may have been founded upon conjecture.

From the condition of the fragments of weapons found at Hogmoor, and from the circular tumuli on the ridges surrounding the forest. basin, it seems, further, to be a probable conjecture that this part of the parish of Selborne was a battle-field in lioman-British times; and the burial of so large a quantity of money in one spot, and the burying and casting away of another quantity (perhaps more valuable) in the water within a quarter of a mile of the same spot (on both sides of which water tumuli now appear), seem to tell a tale of panic and flight. If we ask how so large a number and variety of coins, thus hidden and cast away; came to be brought together (including, as they do, some so imperfectly minted, that they can hardly have been issued for circulation), it occurs to me, as a not improbable supposition, that they may have been hastily collected and carried off from some station in which there was a military chest, and perhaps also a mint, either to provide for the pay of a retreating army, or to prevent them from falling into the hands of an approaching enemy. The Roman Clausentum (now Bittern, near Sonthampton) was a garrison town, in which there was also a mint, in the times of Caransius and Allectus; some of whose coins, found at Blackmoor, bear the mint-marks of that place. The latest in date of all the coins found are eighty-two of Allectus, and a single coin of Constantius Chlorns:- of which the legend is, "FL. VAL. CONSTANTIUS NOB. C." (Flavius Valerius Constantius Nobilis Casar); and, on the reverse, "VIRTUS AUGG," (Virtus Augustorum); with the device of Hercules leaning on his club, and holding a bow, with the lion's skin over his arm :plainly, one of his early coins, before his accession to the Empire. The date, therefore, of their deposit cannot bave been earlier than the reign of Allectus; and if it had been later than the re-conquest of Britain by Constantius, it is not probable that only one coin of that prince would have been found.

On the other band, there would be nothing in the occurrence, among this treasure, even of several coins of Constantius, while only Cæsar, inconsistent with the hypothesis that it inay have 


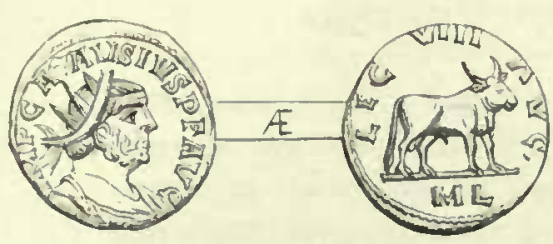

Ho. I Coln of Carausius.

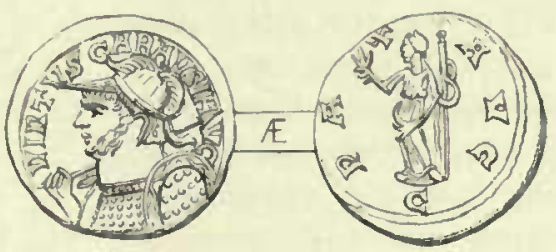

Fio. 3. Cols of Caraugius.

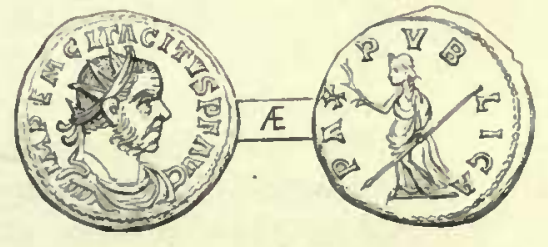

Fro. 3.-Cons of Tacitis.

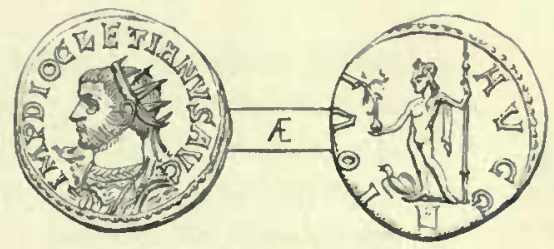

Fig. 4-Cols on Dioceftias.

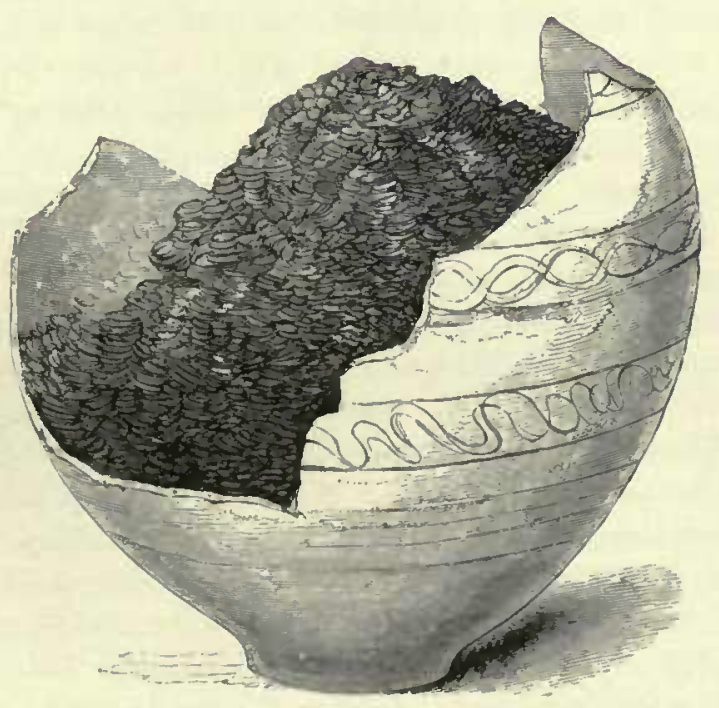

Fic. 3. 

belonged to Allectus himself, and may have been buried and cast away at the time when his retreat from the coast was intercepted by Asclepiodotus, the Pretorian prefect of Constantius, and when the engagement took place in which Allectus lost his life. Coustantius was made Cresar by the Emperor Diocletian, A.D. 292, four years before his invasion of Britain, while Carausius was living; and nothiug is more probable, than that during that interval coins struck with the effigy of Constantius might obtain currency in Britain.

My own conclusion is, that in the basin of Woolmer Forest, and in the neighbouring ridges and hills, we have probably the scewe of important events, of which a narrative, strictly contemporaneous, has been preserved to us, in the panegyric of the orator Eumenius, pronounced in honour of Constantius Cresar, on his recovery of Britain.

Carausius, a native of the country between the Meuse and the Scheldt, of the same Belgic race by which, as early as the time of Julius Cæsar, Hampshire and the adjoining maritime parts of England were peopled, and a man of high reputation in naval warfare, was intrusted by Diocletian, soon after his succession to the empire, with the defence of the northern coast of Gaul from the incursions, then already frequent, of Saxon and Scandinavian corsairs. This he did successfully; but, being accused of permitting the corsairs to commit depredations, with the view of appropriating the spoil, when recaptured, to his own use, Maximian ordered him to be put to death. Carausius then (A.D. 286) declared himself independent, and established an empire of his own in Britain; retaining also Boulogne, and otlier neighbouring places in Ganl. To Britain be carried over with him the fleet under his command, which had been equipped for the defence of the opposite coast; and he built other ships of war in British ports, manning them with merehant seamen from various parts of Gaul, and with fighting men, attracted to lis service from different barbarous nations, whom he instructed in naval as well as military warfare. The Roman legion, or legions, stationed in Britain, acknowledged his sovereignty ; which seems, from traces still remaining in various parts of the island, north as well as south, to have extended throughout Great Britain. 
The condition of this island, improved by two centuries and a half of Roman civilization, was at that time highly prosperons. "Non mediocris" (says Enmenins), "jactura erat reipublicæ terra, tanto frugum ubere, tanto læta munere pastionum, tot metallorum fluens rivis, tot vectigalibns quastnosa, tot accincta portnbus, tanto immensa circuitu." Caransius became a considerable potentate-in naval power, especially, superior to the Romans; who, since their conquest of all the countries bordering on the Mediterranean, had neglected maritime warfare. Maximian in vain attempted an expedition against him; and in A.D. 289 terms of peace were agreed to, by which that prince and Diocletian recognised him as (in Britain) their partner in the empire.

When, however (A.D. 292), Constantius and Galerius were created "Cæsars" (or presumptive successors to the empire), Constantius, to whoin the govermment of Gaul, Spain, and Britain was assigned, lost no time in attacking Boulogue and reuniting to the empire that and the other continental possessions whicl Carausius still held. But no invasion of Britain appears to have been then apprehended.

In A.D. 294 Carausins was assassinated by his friend and minister, Allectus, who himself assumed the purple in Britain. Preparations were now made by the Roman eniperors for an invasion ; and in the third year of Allectus (A.D. 296) Constantius, having collected two fleets of transports, one at Bonlogne and the other at the moutl of the Seine, set sail with a considerable force from both ports simultaneously (himself enbarking at Boulogne), with contrary winds, and in thick, foggy weather. Part of the expedition lost its way, and eventually sailed up the Thames to London; the main body, with Constantius himself and his Præetorian prefect Asclepiodotus, made for the British coast opposite the Isle of Wight, near which the navy of Allectus was on the look-out for them. Under cover of the fog, that part of the force which was under the command of Asclepiodotus passed unseen by the British fleet, and effected a landing, setting fire, immediately afterwards, to their ships. Allectus who was in possession of the neighbouring port (doubtless Portsmonth), and encamped upon the shore, hastily abandoned 
lis position, and retreated inland, as soon as the sails of the ships which followed with Constantius came in sight. His retreat was cut off, and his army surprised, after it had advanced some distance into the interior, by the force under Asclepiodotus. The British troops were totally routed, and Allectus and many of his followers were slain; whose bodies, distinguished by their long, fair laair, and gay, barbaric apparel, were found dispersed over hill and plain in various directions -while searcely one Roman soldier perished. The remnant of the British army made its way to London, inteuding first to pillage, and then to abandon that city ; but, meeting there with those troops of Constantius who had sailed up the Thames, it was put to the sword. And thus Britain was recovered to the lioman empire.

Such (supplying only, from other sources, some of the introluctory facts, with the names of Asclepiodotus, and of Carausius, whom the orator calls the "arch-pirate," and Allectus, whom he styles a "satellite" of Carausius, and the "standard-bearer" of the rebel party) is the substance of wbat we learn from Eumenius. The passages most material to the question of the identity of the battle-field with Woolmer Forest, are subjoined, in the original Latin.

"Ad tempus ipsum tanta se dorso maris nebnlæ miscuerunt, "ut inimica classis, apud Vectam insulam in speculis atque "insidiis collocata, ignorantibus omnino hostibus proteriretur. . .

"Jam vero idem ille vestro auspicio invictus exercitus, statinı "atque Britannia litus invaserat, universis navibus suis injecit "ignes. . . I Ipse autem Signifer nefarire factionis, cur ab eo "litore, quod tenebat, abscessit, cur classem portumque deseruit, " nisi quod te, Cresar invicte, cujns imminentia vela conspexerat, "timuit jam jamque venturum? . . . Te tamen ille fugions, "incidit in tuorum" manus; a te victus, a tuis exercitibus "oppressus est. Denique adeo trepidus, et te post terga respi"ciens, et in modum amentis attoniti properavit in mortcm, ut " nec explicaret aciem, nec omnes copias quas trahebat instruxerit, "sed cum veteribus illis conjurationis auctoribus, et mercenariis "cuneis barburorum, tanti apparatûs oblitus, irruerit. Adeo, "Crsar, hoc etiam reipublicæ tribuit vestra felicitas, ut nemo fere 
“ Romanus occiderit, Imperio vincente Romano. Onnes enim "illos, ut audio, campos atque colles non nisi teterrimorum " hostium corpora fusa texerunt. Illa barbara, aut imitatione " barbariæ olim eultu vestis et prolixo erine rutilantia, tune "vero pulvere et cruore fredata, et in diversos situs tracta, sicuti " dolorem vulnerum fuerant secuta, jacuerunt. Atque inter hos "ipse Vexillarius latrocinii, eultu illo quem vivus violaverat "sponte deposito, et vix unius velaminis repertus indicio. Adeo "verum, ubi dixerat, morte vicinâ, ut interfectum se nollet "agnosei.

" Enimvero, Cæsar invicte, tanto Deorum Immortalium tibi "est addicta consensu, omnium quidem quos adortus fueris "hóstium, sed pracipue internecio Franeorum, ut illi quoque " milites vestri, qui, per errorem nebulosi (ut paulo ante dixi) " maris abjuncti, ad oppidum Londiniense pervenerant, quidquid " ex mercenariâ illâ multitudine barbarorum prælio superfuerunt, " cum direptî civitate fugam capessere cogitarent, passim totâ " urbe confecerint, et non solum provincialibus vestris in cæede " hostium dederint salutem, sed etiam in spectaculo voluptatem." The inferences to be drawn from this narrative appear to me to correspond with those which I derive from the evidence of the buried weapons and coins, and the tumuli upon the ridges surrounding the basin of Woolmer Forest. If (as is manifestly probable) Asclepiodotus landed between Portsmouth and Chichester, and if Portsmouth was the harbour near which Allectus took up the position which he so hastily abandoned, he would naturally fall back upon Clausentum (Southampton) and Venta (Winchester), by the ordinary Roman "Iter:" and, after collecting whatever treasure he found in those places, the more southerly road, corresponding with that which now goes by way of Alresford ${ }^{1}$ and Alton ${ }^{2}$ towards Farnham and London, would probably

1 A writer on the antiquities of the neighbourhood of Bicester, Oxon., in Kennett's "Parochial Antiquities," supposes (somewhat fancifully) that the first syllable of the name of Alresford, and of some other places, was derived from Alleetus.

3 Farnham was a military station; whether identieal with "Vindomis" or not is a matter of controversy. Alton was certainly a Roman town. About thirty or forty years ago some interesting remains were found there, in ground now occupied as a timber-yard by Miessrs. Dyer, some of which are still in the possession of the Messrs. Dyer, and others are in the British Mluseum. They consisted 
be that which he would take, as offering the best ehanee of eseape, if he were closely pursued. From Alton, if he heard that Constantius was following him, by turning a few miles to the southward, to the station or settlement which (as has been seen) existed at or near Blackmoor, he would obtain the proteetion of a country probably then more difficult of aceess, in the immediate neighbourhood of the great Forest (Sylva Anderida), which certainly extended as far north-west as a part of Rogate, near the southern boundary of Selborne parish. In order to aceount for his meeting there with the Roman army, under Aselepiodotus, nothing more is required than that we should suppose Constantius, soon after landing, to have ordered his Pretorian prafeet to eross the lills, through the country of the Meanvari, in the direetion of Alton or Farnham, for the purpose of entting off the eommunications between Allectus and the military stations to the east and north-east of Winchester. The route which Aselepiodotus would follow, in the exeeution of snch orders, would naturally take him, by Porehester and West Meon ${ }^{1}$ (both Roman stations), either to the valley of Petersfield, up whieh he would move to Woolmer Forest, reversing what Mr. Sewell deseribes as Vespasian's mareh, or along the upper level of the ehalk lills to Selborne or some point near it, from which he might descend suddenly upon the enemy in Woolmer Forest, unprepared for his approneh. The expressions of the oratur, "te fugieus," "te post terga respiciens," "ineidit in tuorum manus," favour the hypothesis of such a counter-

of several sepulchral vases, set in dishes or saucers; two lachrymatories; a small wooden dice-box; a small lan:p; and a signet-ring of onyx, set in gold, whicl was still (when found) on the calcined bone of the wearer's finger. On this seal are engravel four sinall figures, set upright, parallel to each other; those in the centre representing an amphora and an ear of bearded corn, between an axo with fasces on one side, and a quiver with arrows on the other. There were also some small pieces of Samian, or British Samian, ware.

I There is an earthwork on Old Winchester Hill, at West Meon, supposed to have been the castra astiva of a lioman garrison, in the conntry of the Meanvari, a tribe whose appellation is still preserved in the names of East and West Meon and Meoustoke. At the neeting of the Archreological Association, held at Winchester in 1845, Colonel Greenwood exhibited a Roman terra-cotta lamp fouml within this encampment, and some fragments of Roman pottery found in a barrow near it, together with sono remains of linman weapons found at Bramlean, a few niles further north, in the same high chalky district.

VOL. II.

M MI 
march by Asclepiodotus: and nothing can better agree with the character of the ground, on which I suppose the two armies to have met, than the words, "omnes illos campos atque colles," which "teterrimorum hostium corpora fusa texerunt." The dispersion of the bodies of the fallen, "in diversos situs tracta," agrees also with the positions of the tumuli (some in groups, and some isolated) which, if my identification of the battle-field is correct, may perhaps now cover, or formerly have covered, some of their remains.

BLACKMOOR, November 1874. 
I N D E X. 



\section{N D E X.}

A.

A berdavines, i. 117

Acclimatizing plants and aninals, i. 224 Enanthus (see Wheatear)

Ėnas (sce woodpigeon)

Affection among animals, i. 137, 160, 183

Africa, migration of birds to, i. 115 , ii. 120

Air, elastie at midnight, i. 218

Alauda pratensis, rearing young euek oo, i. 112,123

Alice Holt Forest, i. 1, 25, ii. 183 fallow deerin, i. 19, 26; leased by the erown, i. 25 ; soil of, i. 25 ; timber in, i. 26

Alton, hollow lane leading to, i. 11, ii 11: manufactures of, i. 13, 14

Ainericau animals, origin of, i. 77 ; junipers, i. 250 ; water-wced, ii. 30

Ampbibions animals, i. 104

Anathoth, an, i. 220,276

Ancient burying ground, ii. 247 ; vases found at Chapel Field, ii. 253

Andalusia, birds of, i. 92, 123 ; stone curlew in, i. 116

Anguilla (sce Eel)

Anguis fragilis (see Blind worm)

Animals eating thcir young, i. 140

Anne, Queen, in Wolmer Forest, i. 16

Antelope, double nostril of, i. 45

Antipathy of birds and animals to their young, i. 140, 223

Antiqnities, at Selborne, ii. 31, 253 ; fonnd near larnstaple, ii. 31

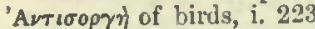

Aphides (smother flies) shower of, i. 26!, 288

A pril, remarkably inelement, i. 105

Aquaria for fishes, i. 263

Ayuatic plants, i. 226

Armadillo, seales of, ii. 111

Arrows, poisonous, of Indian, ii. 141
Arum, the cnckoo pint, i. 49 ; thrusl feeding on the roots of, i. 49

Arun, River, the, i. 3, ii. 14

Ash tree, ruptured, i. 199

Ash ford, last Prior of Selborne, ii. 227

Ashmolean MInseum, Oxíord, ii. 24

Ash-shrew, i. 199

Aspen, shiver leaf, old, ii. 10

Asses plonghing, i. 185

Angust, the mute montl, i. 168, ii. 69 Augustine Canons, ii. 179

Auk, little, i. 145

Aweto, the, ii. 143

B.

Bacon-fly, i. 124

Bait for pike, ii. 29

Bank-swallow (see Sand martin)

Bank martin (see Sand martin)

Baptist, St. John the, little finger of, ii. 215

Barnstaple, antiquities found near, ii. 31

Barometers, i. 276

Barragons, manufacture of, i. 13

Barrington, Hon. Daimes, who he was, ii. 15

Batfowlers eatching birds, i. 98 , ii. 78

Bats, i. 36, 160; appearance of, in warn weather, $i .30,212$; hybernation of, i. 30,31 ; tame, i. 36 ; food of, i. 36 , ii. 39 ; drink flying i. 37 ; little, i. 92 ; breeding of, i. 129 ; anatomy of, i. 130 ; tame, from Bruges Cathedral, ii. 39 ; in churehes, ii. 40

Bat, great, new speeies of, i. 73 ; food of, i. 92

l3ean's pond, i. 21

l3ears in Hampshire, ii. 153

Beasts and birds, taming of, i. 68 , ii. 59

Beaufort, Bishop of Winchester, ii. 209 ; register of, ii. 211 
13ees, drink flying, i. 145 ; Vircil's, i. 145,219 ; and idiot boy, i. 197, ii. 130 ; swarming in lhot weather, i. 211 ; injured by echoes, i. 219 ; insensible to sound, i. 220 ; injured by heat and cold, i. 278; eating loney dew, i. 288 ; sting of, immunity from, ii. 130

Bee bird, i. 120

Beech, the, i. 1

Beetles, i. 183

Belfry of Selborne Cliureh, ii. 167

Bell, Professor, ii. 4

Bells in Selborne Churel, ii. 167

Berne, Canon, Prior ol Selborne, ii. 223 ; provision for, ii. 226

liezoar stones, ii. 107

Bilberry, ereeping or Cranberry, i. 226

13in's poud, i. 21 ; parsonage, ii. 173

Binstead parish, i. 26

3irdcatcher, experience of a, ii. 13

Birdeatching, niodes of, ii. 42, 44-47, $56,78,102,109$

Birds, without English names, i. 32, 247 ; inlluenced by colour in choice of food, i. 33 ; of passage, i. 33 ; settling on ships at sea, i. 44 ; colour of, in fluenced by food, i. 48,145 , ii. 46 ; turning black, i. 48 ; of summer pas sage, i. 53, $80,87,113,115,120$ 153 ; iustinct of, i. $78,96,138,161$, 266 ; soft billed (non-migiatory) i 81; of winter passage, i. 81,87 ; wintering in England, i. 81 ; singing after midsummer, i. 82, 87, 101 motions of, i. $83,106,228$, ii. 89 singing, are all Passeres, i. 88 ; in full soug till midsummer, i. 88 ; that sing in the spring, i. 88 ; with slight notes, i. 88 ; wlich sing flying, i. 89 ; with a song, i. 89 ; some tame, others shy, i. 89 ; breeding early, i. 89; in Ascension Island, i. 89; of Andalusia, i. $92,116,123$; singing dnring incubation, i. 93 ; fatten in frosts, i. 101 ; pairing of, i. 103, ii 89,125 ; migration of, inflnenced by the weather, i. 103,105 , ii. 89 ; food of, i. 105, 108 ; colour of, changing at breeding time, i. 106; thick billed, i. 106 ; transport of, on board ship, i. 108, ii. 93; collections of contain few soft-billed birds, i. 108 washing, i. 111 ; that dust do not wasl, i. 111; which are pulveratrices, i. 111 ; migration of, to Africa, i. 115 , ii. 120 ; of prey, i. 120,163 ; nigration of, over the sea, i. 121 swarms of different varieties, i. 132 . singing in spring and autumn, i.
169 ; drinking, i. 170 ; growth of i. 184 ; congregating, i. 191 ; dis persion of, i. 223 ; destroyed while migrating, i. 223 ; notes and langnage of, i. 230 ; migration of, ii. 12 ; of Sussex, collection of, ii. 15 frightened at gloves, ii. 59 ; arrival of, ii. 62 ; seen at Kinberley, Norfolk, ii. 63 ; seen at Zoological Garl ens, London, ii. 65 ; moulting, ii. 69 ; English, exported to New Zealand, ii. 93; soft-billed, caught in April, ii. 100 ; English, in Africa, ii. 120 ; migratory, leaving the Soutl Coast, ii. 121

Bird's-nest ophrys, i. 227

13ittern, ii. 60

Black act, the, i. 19

Blackbird, i. 49 , ii. 80 ; killed by frost, i. 284 ; nest of, made with paper, ii. 63 ; nest of, ornamentel with lace, ii. 70 ; note of, ii. 71 pugnaeity of, ii. 72

Blackeap, i. 32, 36, 93, 154, 172, ii. 73 ; arrival of, i. 33 , ii. 73 ; food of i. 172 , ii. 73 ; note of, i. 172 ; eggs of, ii. 73 ; nest of, ii. 73

Black death, the, ii. 146

Black dolphin, i. 125

Black canons, ii. 179

Black game at Selborne, i. 16

Blackmoor farm, ii. 252 ; cnrious eustom at, i. 21

Black rat, old English, ii. 35

Blindworm, i. 57

Blossoming of plants, i. 227

Blue-bottle flies, ii. 105

Blne rag, i. 10

Boa constrictor, ii. 54, 67

loors, wild, in Wolmer Forest, i. 26

Boars, fierce, tamed by losing their tusks, i. 206

Bogs in Wolmer Furest, i. 14, 273

Bohemian chatterer, i. 33

Bohemian waxwing, i. 38

Booby, the, i. 89

Books in White's library, ii. 5

Botany, its utility, i. 224

Botfly, horse, i. 71,125 , ii. 105

Bower bird, ii. 71

Boy bee-eater, i. 120

Brain of horse, ii. 129

Brambling, greater, i. 91

Breathing of deer, i. 45 ; goats, i. 46

Brighton, fall of eliffs at, i. 23 ; bustards at, i. 113 , ii. 99

Brimstone Lodge, i. 21

Bristowe, D., Vicar of Selborne, be quests of, ii. 176

Brooks and springs at Selbornc, i. 23 
Bupk, head of, i. 64

Buckland, Frank, birth of, ii. 4 ; Rev. J., Rector of Warborough, ii. 4

Buffalo, wild, in Wolmer Forest, i

Bug, harvest, i. 124

Bullfinch turning black, i. 48, 145, ii. 46

liullhead, i. 35

l3nlruslı caterpillar of New Zealand ii. 143

luntiugs, i. 42, 113

Bunting, reed, i. 106

Burning the heatl, i. 20

Burnt wood-ashes as nanure, i. 20

Bustards, i. 89 , 131, ii. 98 ; similar to stone curlew, i. 116 ; at Brightur, i. 113 , ii. 98

Butcher bird, great asli-coloured, i. 143 , ii. 55 ; red backed, i. 63,143 , ii. 55 ; food of, i. 63, ii. 55 ; note of, ii. 55

Butco apivorus or vespicornes (see IIoney buzzard)

Buzzard, honer, i. 155, 252

Byfields Cliarity, ii. 17 \&

c.

Caddis fly, i. 180

Calculns from stomacl of ox, i. 126 . from stomach of horse, ii. 107

Calendar, naturalists", i. 295

Call of birds, i. 230

Canaries, ii. 41 ; naturalized, i. 140 ; soug of, ii., 41 ; varieties of, ii. 42

Cancer cured by toads, i. 59

Cane (see Weasel)

Capons, i. 206

Caprimulyus, (see Goat-sucker)

Carniola, birds of, i. 106, 109

Carp, i. 22, 263 ; tame, $\dot{1} .171$; in severe weather, i. 171 ; large, ii. 30 ; eggs of, ii. 30 ; seales of, ii. 110

Castration, i. 206

Caterpillars, ii. 50

Caterpillar vegetable of New Zealand, ii. 143

Cats, i. 208 ; fond of fish, i. 104, ii. 96 ; eatching swifts on the wing, $i$. 183 ; suckling a leverct, i. 209 ; suckling a squirel, i. 209 , ii. 87 ; eating crickets, i. 245 ; electrie, i. 280 ; at Selbome, numerous, ii. 14 ; eutching swallows, ii, 14; and rabbits, hybrid between, ii. 28 ; in rabbit holes, ii. 86 ; half tame, half wild, ii. 87

Cattlo frequenting the water, i. 23 ; injured by eating yew, ii. 41,170
Cliafers destroving foliage of trees, i. 123 ; varieties of, ii. 61 ; fern, i. 71 , 130,170

Challinch, i 4J, 49, ii. 42; separation of sexes, i. $41,117,145$; food of, $i$. 95 ; two varieties of, ii. 43 ; taning, ii. 43 ; song of, ii. 45

Chaffinches, lien, flock of, i. 41, 117 ; migration of, i. 41

Chalkhills, beautiful, i. 152

Chantry, what is a, ii. 197

Chapeltield, ii. 186, 238, 253; antiquities found at, ii. 253

Charadrius himantomis (stilt plover?) i. 247 ; oedicnemus ( $\sec$ Stone-curlew)

Chancer, ii. 213

Cliff-chaff, i. 49,138 , ii. 47,48

"Chinky-chank" (see Chill-chaff)

Chimney Swallow (see Swallow, chintney)

Chinese dogs, i. 271

Chlora verfoliate (sce Yellow wort)

Cholera and tlies, ii. 106

Choughs, Cornish, i. 112, 144, ii. 11 i

Chrysomela oleracea (see Turnip fly)

Church at Selborne, ii. 9,157 ; exterior of, ii. 167; built ont of the castwarl position, ii. 169 ; yards, ii. 168 ; trees in, origin of, ii. 172

Churches, searcity of in Sussex, i. 68

Churn owls (see Fern owls)

Churr worm (see IIole cricket)

Chrysosplenium oppositifolium. (sec Opposite Golden Saxifrage)

Claws of heron, i. 69 , ii. 60

Clay's Pond, fossils at, i. 8

Clock made by General Howe, i. 25

Colwwebs, shower of, i. 189 , ii. 127

Coccus vitis vinifero, i. 259

Coins fonnd in Wolmer poud, i. 24, ii. $31,153,251,254$

Cold injurious to vegetation, j. 277

Colnur influencing birds' choice of food, i. 33 ; of birds influenced by food, i. 48 ; of birds in pairing time, i. 106

Coluenba livia (blue rock pigeon), i. 254

Coluber natrix (English snake), i. 57

Colymbus glacialis (see Diver, or loon)

Comarium palustree (see Mlarsh cinquefoil)

Comb, kept for the use of hinds, ii. 216

Conduit wood, ii. 237

Cormorant, ii. 60

Comish clioughs, i, 112, 144, ii, 117

Corn mill at Selborne, ii. 239

Cornua Ammonis, i. 8

Corrodies, meaning of, ii. 205

Corvus monedula (see Jackdaw) 
Country-made candles, i. 194

Cow's liorn, structure of, ii. 112

Cows congregating, i. 191

Crabs used for linnting rabbits, ii. 26 ; man's hand scized by, ii. 41

Cranmer lake, i. 22

Cressi Hall heronry, i. 69,73

Cricket, eggs of, i. 240 ; field, i. 240 ; sex of, i. 241 ; wings of, i. 241 , 244,246 ; chirping of, i. 241, 242 . fen (sec Cricket. mole) ; molc, i. 241, 245 ; house, i. 243 ; tame, i. 243 ; fool of, i. 244 ; liabits of, i. 244 to destroy, i. 245 ; nest and eggs of, i. 246 ; chewing the cud, i. 247 ; cry of, i. 248

Crocodile, structure of, ii. 110

Ciocus (sativus crocus), spring and autumnal, i. 227

Crops of birds, ii. 66

Cross bills, i. $35,112,155$,ii. 37

Cyprinus auratus (gold tish,) i. 263

Crow, i. 144 ; grey or hooded, i. 170, ii. 124

Cuckoo, i. 95 , ii. 74 ; choosing a nest, i. 94 , ii. 74 ; eggers of, i. 96,102 ; skimming fliglit of, i. 112 ; food of 1. 112,123 ; in nest of tit-lark, $i$. 112,123 ; reared by Alauda pratensis, i, 112, 123 ; sings in different keys, i. 127 ; when it sings, hawks lo not prey on other lirds, i. 185 ; anatomy, i. 203; why it does not lintch eurs, i. 203, 204; in Loudou, ii. 66 ; reared by sparrows, ii. 74 young of turning other birds ont of nest, ii. 75 ; notes of, ii. 76

Cuckoo, pint, the, i. 49

Curlew, stonc (see Stone curlew)

\section{D.}

Daker-hen (see Landrail)

Danewort, i. 227

Daphne laureola (springe laurel); Mcarereum (M egeron) i 226

Daw (sec Jacklaw)

Daws, breeding places of, i. 66 , ii. 57

Deafuess of Gilbert White, i. 187

Death, Black, the, ii. 146 ; the end of all, ii. 13

Decay of Selborne Priory, ii. 217

Deeds dated on Sumulay, ii. 198

Deer, fallow (see Fallow deer) ; forests, management of, ii 20 ; moose (see Bloose 1)eer); red (s:c Red 1)eer); hunting, i. 16 ; killiug a dog, i. 19

Deer, breathing spiracula of, i. 45 , ii. 23 ; stealer's, i. 18, 26
Desecration of Communion Tables, ii. 206,207

Destruction of martins, i. 15 i

Destructive frosts, 1. 45, 27 $7,291,294$

Dew collected by trees, i. 200

Disease in cattle, caused by Estrus bovis, i. 71

Diver or loon, i. 82 ; gait of, i. 83

boe, brought up with cows, i. 191; tame, chased by dogs, i. 192

Dog, Chinese, i. 271; eating vegetubles, i. 271

Dogrs, killed by deer, i. 19 ; blinded by cobwebs, i. 189 ; Chinese, i. 271 ; of South Aneriea dumb, i. 271 ; ears of, i 271 ; fed on veintables, i. 271 ; refusing to eat birds that they luut, i. 272

Dove-ring (sec Ring-llore) ; Stock (sce Stock-dovel

Dover burnt by the French, ii. 190

Uove, stock, i. 252 ; house, i. 252 ; de. rived from blue-rock picreon, i. 254 ; ring, reared by pigeons, i. 256 ; anıl pigeons, cross between, i. 256 ; house at Selborne Priory, ii. 236, 239

Downs, South, i. 152 ; sleep on the, i. 152

Diagonlly, i. 112, 165

Dress of eanous in 1387 , protest of Bishop Wyksham fugaiust, ii. 206

Drinking, mode of, it deer and horses, i. 45

Drosera rotundifolia (round-leaven sundew), i. 226 ; longifolia, i. 226

Ducks, wild, i. 23,35 ; ill Wolmer Forest, i. 15 ; King of Denmark's, foum in England, i. 121 ; rearing of, ii. 95 b) ung of cattle, food for fish, i. 23

\section{E.}

Eagle, migration of, i. 120

Early-breeding birds, i. 89

Earthquakes in Sicily, i 289

Earthworms, i. 210 , ii. 141 ; anatom and uses of, ii. 142

Eastwick, i. 93

Echoes, i. 217, 220, 275, ii. 146 ; re. peating teu syllables, i. 217 ; described by Ovid, i. 217 ; rules of, i. 218 ; described by Virgil, i. 219 ; injurious to bees, i. 219 ; destroyed by intervening objects, i. 220 ; a place of, $j$. 220,276 ; to make, i. 221 ; described by Lucretius, i. 221 ; at Westmins. ter Abbey, St. Paul's, and Gloncester catheural, ii. 148

Edward II. in Wolmer Forest, ii. $15 \%$ 
Edward III. in Wolmer Forest, ii. 158 Eels, i. 22, 35 ; breeding of, i. 54, 167 two speeics of, i. 167 ; how to catub, ii. 38 ; large, ii. 38

Eft, i. 55 ; water, larva of land-eft, i. 55

Egrss, of carp, number of, ii. 30 ; in larvæ of insects, i. 60

Elder, dwarf, i. 227

Electricity, i. 291

Elephant, tusk of, growth of, ii. 26 injured by bullet, ii. 27 ; tormented by rats, ii. 37 ; tormented by tlies, ii. 106 ; note of, ii. 116

lilk, European, i. 100, ii. 79

Elms, broad-leaved or wych hazel, large, i. 5 ; common, ii. 17

Emberia miliaria (bunting), ii. 46

Einberiza nircalis (snowlake), ii. 46

Entomology, i. 73, 126

Ephemera (mayflies), i. 180

Eunuehs, i. 206

Euonymus Europoens (spindle-tree) i 170,226

Eve-churr (see \$lole-cricket)

Evejar (sec Fcrn-owl)

Eyes and ears, large, uses of, i. 142

F.

Fair at Selbornc, ii. 157, 246

Falcons, i. 32, 34, 37, 270

Falco peregrinus (haggard falcou), i. 270

Fallow-deer, in 11olt Forest, i. 26 ; never scen in Wolmer Forest, i. 26 head of spiracula in, i. 45 ; iniported from Norway by James 1., ii. 21

Fatteniug of animals during frost, i. 101

Faustina, Empress, ii. 154

Fellwort, i. 226

Fens of Lincolnshire, The, i. 70

Fertl-chafers, i. $71,130,170$

Fern-owl (sec Goatsucker)

Field-ericket (sec Crieket, fie]d)

Fieldfarcs, i. $29,85,90,98$, ii. 78 . feeding in wiuter, i. 33 , ii. 78 ; not brceding in England, i. 90 ; roost on the ground, i. 98 ; breeding in England, i. 118

Field-mouse, i. 32, 37, 49 ; and young, i. 139 ; eating nuts, i. 267

Fig-trecs in Im ia destroying buildings, ii. 11

Fish, shell, petrified, i 7 ; at Sclborne, i. 22,35 ; dead, why they float, 262 ; gold, i. 262 ; silver, i. 262 ; fonl of, i. 263 ; bowls of, with birds inside. i. 263 ; scales of, ì. 110 ; pouds, ii. 246

Vlumingo, i. 248, ii. 149 ; feeding its young, ii. 150

VOL. II.
Flies, plague of, i. 289 ; annoying elephants, ii, 106 ; and cholera, ii. 106

Flight of birds, i. 162, 229, 230; insects, i. 244

Floods in 1764, i. $162 ; 1784$, i. 291

Flera of Selborne, i. 225

Fly, turuip, i. 125; depositing egg in hairs of horses, i. 125 ; horse hot (sec horsc-fly) ; forest, i. 142 ; side, i. 142 ; louse maggots of, ii. 106

Flyeateher, i. $31,36,52,138$; arriva of, i. 33 ; instinet of, i. 139 ; nidification of, i. 172 ; noto of, $i, 172$ spotted, ii. 114 ; pellets east up by, ii. 114

Fogs, i. 200, 202 ; smoky, i. 289

Food of titlark, i. 33 ; of suft-billerl birds, i. 30 ; birds guided by colonr in cboice of, i. 33 ; of birds, i. 118 ; of man, various, i. 224 ; of woodpecker, ii. 93

Foot of woodpceker, ii. 91

Forcst-flies, i. 142

Forests, services reudered by, i. 19 ; ef-

- fects of on the weather, i. 201 ; royal origin of, ii. 157

Fossils at Sellorne, i. 7 ; wood, i. 14, 273 ; oak, i. 273

Foxe, in Wolmer Forest, i. 21

Freestone, analogons to ehalk, i. 2; grows shaky wood, i. 4 ; its uses, i. 8

French naturalists, i. 107

Fringilla (hard-billed), i. 175 ; colebs (sce Claffinch)

Frogs, i. 54 ; brecding of, i. 55 ; swarm ol, cause of, i. 55 , ii. 49 ; migratin of, i. 55 , ii. 49 ; enltivation of, ii 50 ; eroaking of, ii. 50

Frosts, lying longer on bog oaks, i. 14; severe, i. 45, 277, 231, 284; bird fattening during, i. 101; effects of on animals, i. 101 ; ctlect of on birds, i. 102

Fruit crop, i. 156

\section{G.}

Gallina, walk of, i. 229

Gallows Hill, ii. 247

Garden, White's, ii. 8

Gardening, i. 215 ; among the Saxons, i. 215

Garlands in churehes in honour of Virgins, ii. 161

Garrulus Bohemicus (German silk-tail), i. 38

Gassendus, quotation from, on music, i. 268

Gasterosterus mengitius (sce Stickleback); aculentus (see Stickleback) 
Gems placed in turkey's crops, ii. 66 Gentian, i. 226 Gentiana amarilla (gentian or fellwork), i. 226

Geology of Selborne, i. 2, 8

Gernan-boars, i. 26 ; silk-tail, i. 38

Gibraltar, migration of birds to, i. 114, 115 ; entries relating to, ii. 15

Gill covers of mud Iguana, i. 56

Gipsies, language of, i. $21,38,193$, ii. 130

Gizzard, of landrail, i. 84 ; of birds, i. 95 , ii. 66

Glow-worm, i. 79

Gnats on the snow, i. 33

Goats, breathing through their ears, i. 46 ii. 119 ; do not take sheep scab, ii. 119

Goatsucker, i. 70, ii. 60 ; note of, i. $70,71,74,102,130$; food of, i. 70 , 176, ii. 60 ; does not injure cattle, i. 71 ; egg of, i. 72, ii. 60 ; makes no nest, i. 73; feeding by means of its foot, i. 130 ; anatomy of, i. 204; tame, ii. 61

Gobirus fluviatilis capitatus (bull-head), i. 35

Goldfinch, i. 101

Goldfish, i. 262, 263

Gold-crested wren (sec Wren)

Golden thrushes, i. 120

Golden maiden-hair, brush of, i. 196

Gossamer, a shower of, i. 189, ii. 127 ; origin of, i. 190, ii. 127

Gracious street, ii. 245

Grallæ, ligs of i. 99 ; food of, i. 128

Graminivorous birds eating vegetables, i. 105

Grange, the, ii. 245

Grass, nses of, i. 225

Grasshopper, i. 241 ; lark, i. 51, 61 , 77,167 ; warbler, ii. 48 ; two kinds of, ii. 49

Gravel in birds' crops, i. 84

Graves under trees, ii. 172

Great Britain, birds of, i. 173

Greatham farm, i. 19

Green lizard, i. 57, 68

Gregarious habits of horses and cows, i. 191

Grosbeak, i. 34 ; food of, i. 34

Gryllus campestris (field-cricket); domesticus (house-cricket); Gryllus talpæ (mole-cricket) (see Cricket)

Guernsey lizard, i. 73

Gurdon, Sir Adam, ii. 183 ; marriage of, if. 184 ; rebellion of, ii. 189 ; menace against the English language, ii. 190 ; death of, ii. 191 ; seal of, ii. 191

\section{II.}

Haggard falcon, i. 270

Hailstorm at Selborne, i. 291

Hampton bridge, i. 6

Hanger, the, i. 2, 13, ii. 10 ; meaning of, ii. 10

Hares, i. 12, 281

Harvest mouse (see Mouse, liarvest) ; bug, i. 124, ii. 10

Hawkley hanger, i. 238

Hawk, sparrow, strange, i. 33 ; blue, i. 168 ; ringtail, anatomy of, i. 204 ; destroyed by poultry, i. 234

Hawks, i. 33 ; casting up featlers, i. 36 ; migration of, i. 120 ; do not prey while cuckoo is hearl, i. 185

Haws, a food for birds, i. 38 , ii. 41 ; failure of, i. 38

Haze, or smoky fog, i, 289

Hazcl wych, i. 5

Heat, intense, i. 287 ; spoiling frnit, i. 287; effects of on hybernating animals, i. 212

Heathcock, formerly plentiful, i. 16

Heatlifires, i. 20

Hedgehog, i. 97 , ii 76 ; food of, i. 97 ; spines of, i. 97 , ii. 76,77 ; hybernating of, i. 98 , ii. 78 ; young of, ii. 77 ; vertebræ of, ii. 77 ; claws of, ii. 77 ; resisting poison, ii 77 ; food of, ii. 78

Hedgesparrow and tho cuckoo, i. 102, ii. 74

Heliotropus, sunumer and winter, i. 235

Hellebomes fatidus (stinking hollebore), i. 226 ; viridis (green hellehore), i. 226 ; niger, i. 227 ; hellebores, order of blooming, i. 227; hyemalis, i. 227 Helleborini, i. 227

Hempseed for birds, i. 48, 145, ii. 46

Hen harrier, i. 167

Hen and lorse, friendship of, i. 192 ; and ducklings, i. 209

Hen, common, i. 233

Henry III. grants lands to Selborne priory, ii. 180

Heronry at Cressi Hall, i. 69, 74

Hills and mountains, pnoving, i. 237 ; attracting clouds, i. 290

Himantopus, i. 247,248

IIippobosece himundinis, i. 142, 258

Himundo, hyberna, i. 114 ; mupestris, 1. 114 ; rlpina, i. 116 ; esculenta, i. 163 (see also Swallow, Martin, and Sivift)

Hogmere, lake, i. 22

Hogs, age of, i 207

Hollow lane leading to Alton, i. 11

Holt, Forest, i. 1, 25, ii. 19 ; ironstone in, i. 10, ii. 19 ; decr in, i. 19, 26 ; meaning of, ii. 10 
Holy Ghost Chapel, Basingstoke, de. struetion of, ii. 243

IIoly water elump, ii. 252

Ilome-made candles, i. 194

Honey-buzzard, i. 155, 252

Honey-dew, i. 288

Hoopoe, ii. 37

Iloopoes at Sclborne, i. 34 ; migration of, i. 120

Hops, suitable soil for, i. 4 ; at Selborne, i. $13,186^{\circ}$; gardens, ii. 12

Horns at Lord Pembroke's, i. 108; of red-deer, growth of, ii. 21 ; cow'a, structure of, ii. 112

Horse botfly, i. 125, ii. 105 ; and ben friendship, i. 192; shonld not be kept in solitude, ii. 128; brain of, ii. 129 ; long tail of, ii. 129

Horticulture, spread of, i. 216

House martins (see Martins, house ; swallow (sce Swallow, honse)

Howe, General, machinery made by, i. 25

Humning, in the air, i. 219 ; birds from West ludies, ii. 94

Hunger, yower of, i. 118, 131

Hunter, John, birth and death of, ii. 4

Hunting condemned by Bishop, Wykeham, ii. 204

Hybermation of swallow, i. 28 ; swift, i. 28

Hybrill between cat and rabbit, ii. 28 ; tench and rabbit, ii. 28

Iypericun androscemum (Tustan, or St. Jolnn's Wort), i. 226

\section{I.}

Iehthyology, i. 67

Icy spicula in the air, i. 286

Idiot boy and becs, i. 197, ii. 10, 130

Incongrutons companions, i. 131

Ineubation of birds, i. 102

Indian grass, i. 73 , ii. 61

Insectivorous birds, i. 34

Inseet pests, i. 125; ; appearing in lot weather, i, 211 ; insensible to sound, i. 220 ; hybernation of, i. 243 ; life of, i. 243 ; diffusion of, i. 259,261 ; a]pearing in frosts, i. 283

Instinet, i. 78, 138, 161, 266 ; of young animals, i. 205

Inuudations rendering land poor, i. 210 lreland and its natural history, i. 187 Ironstone in Ilolt Forest, i. 10, ii. 19; in Sussex, ii. 19

Italy, climate of, i. 103

Ivy tree destroying buildings, ii. 10
J.

Jackdaws, i. 66 , ii. 57 ; building on the groulnd, i. 66,68

Jamaica, birds of, i. 111

Jarbirl (see Goatsueker)

Jealousy in birds, i. 131

Jehovah, ii. 32

John, King, in Wolmer Forest, ii. 15t

July, alleged deerease of birds in, i. 94

Juncus conglomeratus (common msh),

$$
\text { i. } 194
$$

Junipers, American, i. 280

\section{K.}

Kestrel, i. 167

Kingsfield, eeho in, i. 218

Kite, eating ants' eggs, i. 34 ; migration of, i. 120,155

Knights' Templars, Order of, ii. 163 ; property belonging to, at Selborne, ii. 164,192

L.

Lacerta, i. 56 ; greẹn, i. 57

Ladies' traces, i. 227

lakes ncar Selborne, i. 21 ; in Wolmer, i. 22

Lampem, i. 35

Lanurail, i. 12,84 ; food of, i. 84

Landslips, i. 238

Land tortoise (sce Tortoise)

Lanes at Selborne, i. 11, ii. 11 ; aboum in Filiees, i. 12

Laninus minor, i. 86 ; Collurio (see Butcher-bird)

Lapring, i. 15 ; movements of, i. 145

Larks, i. 155 , ii. 47 ; sky, feeling in winter, i. 33 ; white, i. 48 ; grasshopper, i. $51,61,77,167$; wood, i. 101 ; dusting and wasling, i. 123 ; Scotch, ii. 47 ; catching, ii. 47

Late springs, i. 123

Lathroea squammaria (tooth-wort), i. 226

Lathyrus sylvestris, i. 227

Laurel spurge, i. 227

Lcaves of trees, $i .201$

legs, length of, in small birds, i. 247

Lemna (duck'a meat weed), i. 263

Leprosy, i 213 , ii. 145

Leveret. and cat, friendship of, i. 203

Libellulæ (dragon-fly), i. 112, 165

Lice, of insects, i. 142 ; martins, i. 142 , 151,258 , ii. 116; swallows, eggs of, i. 143

Linen elothing, advantage of, i. 214

Linnzan system, the, i. $80,82,85$, 169 
Limnet, i $41,101,113$, ii. 43 ; song of, ii. 43,74 ; taming, ii. 44

Lions following jackals, i. 132 ; eating fish, ii. 86

lithe, the short, i. 240

Iiveries, meaning of, ii. 205

Lizard: green, i. 57, 68 ; black, found in a well, i. 64 ; Gnernsey, turned out at Pembroke College, Oxford, i. 73

loach, i. 59

Loaches from Ambresbury, i. 59

Locusta, i. 51

Locustella, i. 77

Long-billed birds fattening during frosts, i. 101

Longspee, Ela, ii. 198, 199

Longworth, J., Vicar of Selborne, ii. 174

Loon, or spotted diver, i. 82 ; foot of, i. 83

lop and top, i. 26

loripes, i. 247

Losel's wood, i. 5, ii 12

Love in birds, i. 118, 134

Loxic coccothranestes (see Grosbeak). (eurvirostra) (sec Crossbill)

Lyeoperdon tuber (truffle), i. 227

\section{M.}

Alagdalen College, Oxford, i. 4 ; eurions custom at, ii. 58; land belonging to, at Selborne, ii. 188,246 ; patron of living of Selborne, ii. 173 ; founded, ii. 229 ; court list of, held at Selborne, ii. 245

Maggots in cattle, i. 71 ; of house flies, ii. 106

Magpie and missel thrush, fight between, i. 185

Mahommedans dusting themselves, i. 112

Maiden hair fern, i. 196

IIalm, black and white, i. 2

Man-traps, ii. 24

Manor house at Selbome, ii. 185

Marcley Hill said to have moved, i. 237

Market at Selborne, ii. 187, 246

Marsh cinquefoil, i. 226

Martins, young, appearance of, i. 28 late, i. 28,66 ; house, i. $29,36,103$, $110,146,163$; sand, i. $30,114,163$ frequenting water, i. 30 ; late breeding of, i. $36,40,131,144,150,170$ 264 ; migration of, i. 130 ; food of i. 165 ; parasites of, i. 165 , ii. 116 lybernating of, i. 135, 212, 257, 265 nest of, i. 147, 149; down on legs of, i. 151 ; colour of, i. 161 ; sand and house feed young on the wing, i. 110, ii. 96 ; nest of, i. 30,177 ; washing as they fly, i. 166 ; do not sing, i. 165 ; flight of, i. 166 ; abundance of, i. 166 ; appearance of, i. 212

Martlet (see House martin)

Masses for the dead in Selborne church, ii. 197

May-day custom at Oxford, ii. 58

May-fly, i. 180

Mumory, comparing animals by, i. 115

"Meating off" birds, ii. 73

Merops apiaster (bcelvird) i. 12

Merula torquata (see ring ouzel)

Meteors, i. 289

Mezereon, i. 227

Migration of swallows, i. $29,40,74$; of birds, $i$, $33,40,44,75,78,80,101$, $103,105,117,120$; of chaffinches, i. 41 ; of birds, affected by the season, i. 105

Migration, a large, i. 74 ; " home," i. 117 ; at Gibraltar, i. 120

Mildew on hops, ii. 12

Miller's thumb, i. 35

Missel thrush (see Thrush, nissel); bird, i. 144

Mist, sulphurous, i. 291

MIoisture, effect of, on trees, i. 123

Moles, eaten by weasels, i. 167 ; cricket, i. 253,279 , ii. 124,148 ; eating worms, ii. 123 ; paw of ii. 124

Monasteries, effect of, ii. 182 ; deseneration of, ii. 213

Monkey, mummied, found in a tree, ii. 103

Monogamous birds, i. 103

Monograplis, merits of, i. 109, 11

Monolith at Crickhowell, ii. 59

Monument, to Gilbert White, ii. 166 ; to Rev. W. Etty, ii. 166

Moose deor, the, i. 99,115 , ii. 79 ; food of, i. 100 , ii. 79 ; swimming in breeding time, i. 107 , ii. 80 ; appearance of, ii. 80

Mosquitoes, i. 142

Moss on tombstones, to destroy, ii. 9

Motacilla trochilus, i. 31 ; three kinds of i. 32,61 ; atricanilla (see blackcap); salicaria (see Willow wren)

Mother marking, i. 213

Mountains, i. 152

Mouse, i. 44 ; harvest, i. 32 ; new kind, i. $32,37,49$; burrowing, i. 44 ; large, i. 44 ; house, i. 44 ; red, dogs eating, i. 169 ; common, cats eating, i. 170 ; shrew, 199 , i. 72 ; canght by an oyster, ii. 40 ; field (see Field motuse) 
Movements of animals and birds, various, i. 31,223

Mud iguana, i. 56

Mrus amphibius, i. 32 ; minimus (new kind of nouse), i. $32,37,49$; domesticus medius (Ray), i. 37

Musca putris (see Baeon-fly); chamalem, i. 125

Music, influence of, i. 268

Mustella weasel, i. 47

MIustelinum, i. 47

Mytilus, tlee, i. 7 ; fossil, at Selborne, i. 7

N.

Naturalist's summer evening walk, i. 78

Nautilus, fossil, i. 8

Nest of sand-martins, i. 30 ; mouse, i. 38 ; rooks, i. 47 ; swallow on owl's body, i. 160

Newt, or water-eft, i. 55 , ii. 50

Newton Valence eburch, tablet in, ii. 16

Nidification of birds, i. $119,137,163$, 186,266 ; house-martins, i. 147, 266 sand-martins, i. 161 ; ehaffinch, i. 266 ; uthatch, i. 266 ; wren, i. 266

Night, birds eoming forth at, i. 23

Nightingale, i. 152 , ii. 99 ; migration of, i. 122 , ii. 99 ; note of, i. 127 , 167 , ii. 100 ; eggs and nests of, ii 99 ; breeding in Loudon, ii. 101 catching, ii. 102

Nocturnal birds, i. 273

Norehill, i. 2, 237, ii. 15

Nostrils of antelope, i. 45 ; horses and deer, ii. 23, 24

Notes of, birds, i. $31,42,52,82,230$; willow wren, i. 51 ; grasshopper latk i. 51 ; willow lark, i. 62

Noxious insects, i. 125

Nun, i. 176

Nuthatch, i. 50, 53, 266, ii. 48 ; eating uuts, i. 267 ; nest of, ii. 48 ; foot of, ii. 48 ; anatomy of, ii. 61

Nuts opened differently by nuthatel, squirrel, and field-mice, i. 266

Nymphoca (water-lily), i. 100

\section{0.}

Oak, large in the Plestor, i. 5, ii. 186 ; in Losels wood, i. 5 , ii. 12 ; peculiar, i. 5,6 ; bog, i. 14 ; low to tell tbo age of, ii. 18

Oakhanger, i. 13, 21

Oaks of Temple, i. 4; in Wolmer forest, i. 26 ; in Windsor forest, ii. 18
Dedicncmus (sce Stone curlew)

Oil as a remedy for snake-bites, i. 57

CEstrus bovis (bot-fly), causing injury to cattle, i. 71, 125

Ophrys spiralis (see Ladies' traces) ; nidus avis (see Birds' nest ophrys)

Opposite golden saxifrage, i. 226

Oro pendolos, i. 120

Osprey, i. 143

Ostrich, the, i. 96

Otis (bustard), i. 89

Otter, i. 104 , ii. 87 ; killed near Sel. borne, i. 104 ; anatomy of, ii. 88

Ouzel, ring (see Ring-ousel) ; water, (sce Water onzel)

Owl, barn (see Owl, white); brown, casting up fur and feathers, i.36, 142 ; food of, i. 36 ; hooting of, i. 124 nest of swallow on an, i. 160 ; eagle, i. 91 ; fern (see Goatsueker) ; white, i. 140 , ii. 114 ; Joung of, i. 36 ; food of, i. 36, 141; attacking dovehouse, i. 104 ; hawking, i. 140, $\ddot{\text { i. }}$ 114 ; screech of, i. 141 ; voice of, i. 141

Owls, pellets cast up by, i. 36, 142 ; hoot in different keys, i. 124, $12 \%$, i. 116 ; ears of, i. 142 ; eyes of, i. 142 ; flight of, i. 142 ; food of, ii. 115 ; to call, ii. 116

Oxen congregating together, i. 191

Oxford, Gnernsey lizards at Pembroke College, i. 73 ; swallows late at, i. 36,74 ; statues at, ii. 38 ; figures of Mnses at, ii. 38 ; pigeons at, ii. 39 ; curious cnstom at, ii. 58

Oyster, mouse caught by, ii. 40 . cateher, caught by, ii. 41

\section{P.}

Pairing of birds, i. 104

Palm Sunday, yew trees carried on, ii. 172

Palumbus torquatus (see Ring dove)

Pangolin, scales of, ii. 111

Paradise Mede, Selborne, ii. 237

Parasitic insects, i. 142,242 ; of mar tins, i. $142,151,258$, ii. 116

Puris quadrifolia, (herb Paris truelove or oneberry), i. 226

Partridges, i. 12 ; pairing of, i. 104 ; great Hoeks of, i. 115 ; killed by frost, i. 284

parus coruleus, (bluo titmouse or wien), i. 176 ; fringillagus or major, (blackliead titmouse) i. 176; ater, (cole-mousc), i. 176 ; palustris (marsl titnouse), i. 176 
Passer amundinaceus minor (see Reed sparrow); torquatus (sce Reedbnnting) Passeres, note of, j. 232

leacock, tails of, i. 126 ; killing vipers, ii. 107

leas, to prevent mice attacking, ii 40

Peat, i. 14, 19

Pectines in freestone, i. 8

Pelican feeding its young, ii. 149

Perch, i. 22

Peregrine falcon, i. 270

l'erewinkle, lesser, i. 226

Pettichaps (chiff-cliaff), i. 269

Pews in Selborne Church, ii. 161

Phalena (gnats) i. $71,92,161$; bats and swallows feeding on, i. 161

Pheasants, i. 12 ; 1urstred bý hen harrier, i. 168

Phryganea (see Caddis-fly)

Pigeon, wood (see Woodpigeon); drinking, i. 170 ; blue rock, i. 254 ; eating wheat in public roads, ii. 39

ligs, eating their young, i. 140 ; length of life in, i. 207 ; eating yewberies without injury, ii, 170

Pike, large, ii. 28 ; bait for, ii. 29

Pilton, antiquities found at, ii. 31

Pine plantations, near Glasgow, i. 188

Pitancias, ii. 205

Planting evergreens, i. 280

Plants, at Selborne, i. 226 ; suffer from heat and cold, i. 278,285

Plestor, the, i. 5, ii. $8,186^{\circ}$; great oak in, ii. 8,18

Plover, i. 247

Plownan, Piers, ii. 213

Plumpton Plain, i. 152

Poaching at night, i. 18,26

Poison-fangs of viper, ii. 136

Poison, Wourali, ii. 140

Poisoned arrows of Indians, ii. 141

Poll sheer, i. 152

Pollard-ash, children cured of moture by, i. 199; in the Plestor, i. 199

Ponds, on chalkhills, i. 201; at Wolmer, i. 201 ; at Selborne, dried up, ii. 12

Pope Martin confiscates property of Selborne Priory, ii. 212

Portugal laurels, i. 280

Pottery, Roman, found at Selborne, ii. 253,254

Poultry, j. 233 ; their notes and language, i. 233 ; «lestroying a hawk, i. 234

Prayers for the dead, ii. 186, 197, 198, 235

Preceptores, meaning of, ii. 196

Prior, election of a, ii. 199, 216, 218, 221,224

Priors of Selbome, list of, ii. 227
Priories, alien, ii. 181

Priory of Selborne, at Pilton, ii. 31, 177 ; in debt, ii. 208 ; property of, ii. 209 ; sequestrated, ii. 212, 217 ; reduced to a eliantry, ii. 236

Prophecy of Piers Plowman, ii. 214

Puckeridge (see Fern-owl)

Puffins, i. 66 ; breed on flat ground, $i$. 66

Palex imituns (bed-flea), i. 165

Punishment of canons for misbehaviour, ii. 207

Puritanism at Selborne, ii. 174

Purlieus, i. 22

\section{Q.}

Quails, i. 12, 42

Queen's bink, i. 16

Quicksilver mines, men working in, i. 106

R.

Rabbits, in Wolmer Forest, i. 19 ; with delormed teeth, ii. 25 ; ferreted by crabs, ii. 27 ; and cat, lyybrid between, ii. 28

Railings, ronnd St. Paul's Cathedral, ii. 19; Hanover Square, ii. 20

Rainfall, at Selborne, i. 13.73, 275 ; Rutland, i. 119, 281 ; effect of trees on, i. 201, ii. 132 ; compared with Plymoutl, i. 275

Rana arborea (tree-frog), i. 55

Rats, common, i. 34, ii. 34 ; two kinds, i. 32 ; water, i. 32 , ii. 34 ; tluree varieties of, ii. 34 ; black, ii. 35 ; white, ii. 35 ; brown, ii. 37 ; tail of, ii. 36 ; tormenting an elephant, ii. 36 ; dead, how to find out in houses, ii. 106

Rattlesnake, ii. 53, 139 ; camot rattle in wet weather, ii. 140

Ruvens, building in the Plestor Oak, i. 6 ; close sitting of, i. 7 ; driving vultures from their uests, i. 138, ii. 19

Redbreast, i. 93, 101, ii. 125 ; tame, singing by candlelight, i. 94 ; song of, i. 170 , ii. 125 ; autumn songster', i. 170 ; food of, i. 170,175 ; egg and nest of, ii. 125

Red deer, i. 16, ii. 20 ; in Wolmer Forest, i. 16 ; never seen in Holt Forest, i. 19, 26 ; horns of, ii. 21 ; iujuring crops, ii. 20

ledstart, i. $36,52,154$, ii. 125 ; arrival of, i. 33 ; motion of tail of, i. 165 ; song of, i. 172 ; nest of, ii. 126 
ledwing, i. 29 ii. 78 ; feeding in win. ter, i. 33 ; breeding in England, i. I18; migration of, i. 128 ; killed by frost, i. 278

Reed-sparrow, i. 85, 91, 101, 106, 117 ; food of, i. 106 ; song of, i. 106

Reed-wren, i. 86 , ii. 66

Regulus cristatus, ii. 49 ; eggs of, ii. 49 ; nest of, ii. 49

Regulus non eristatus (see Goldenerested wren)

Relies of Selborne priory, ii. 215

Reptiles, breeding of, i. 53 ; stiuking se defendendo, i. 86

ling-dove, i. 95, 123, 253; food of, i. 95,104 ; nidification of, i. 186

Ring-onzel, i. $38,44,63,68,76,90$, $108,123,154$, ii. 95 ; nigration of, $i$ $62,66,68,76,85,90,109,113$ 131 , 135 ; sontluwards, i. 85 ; foot of, i. 64,76 ; breeding plaees in England, i. 144, ii. 95

Rivers near Selborne, i. 35

lioads, at Selborne, ii. 11 ; new, nalle by Gilbert White, ii. 176

Roche, Yeter de la, or de Rupibus, founds Selborne priory, ii. 177 ; Bishop of Winchester, ii. 177

Rocks removed by rain, i. 29]

Roman renıins found at dlton, ii. 264 Selborne, i. 24, ii. 31, 153, 251, 254 invasion of England, ii. 261

lomulns and kenuns, i. 209 , ii. 87

loofs of honses, various, ii. 237

Rooks, i. 155,293 , ii. 46 ; killed by falcon, i. 33 ; nesting of, i. 47 white, i. 47 , ii. 46 ; power of smell in, i. 132 ; frightened by seareerows, ii. 83

Royal forests, origin of, ii. 157

Royston crow, i. 123

Rupert, Prince, i. 25

Ruptured children placed in pollardashes, i. 199

Rush eandles, i. 194 ; to make, i. 195

Rutland, fall of rain in, i. 119, 281

\section{S.}

Satfron, i. 227

Salad or Sallet, i. 216, ii. 147

Salad oil as a cure for viper's sting, i. 57

Salamandra aquatica, (water-newt, or eft), i. 65

Salicaria, i. 49, 76, 85, 91 ; fen (reedwren), ii. 66

Salmo-fario (trout), i. 35

Salinon breeding, ii. 14

Salt meat eausing leprosy, i. 21

Sambucus cbulus (dwarf elder)
Sandmartins (see Martins, Sand): stone, i. 10 ; pipers, i. 62 ; pits in Wolner forest, i. 163

Saxon words, meaning of, ii. 156

Seallops, i. 8

Scaraboces solstitialis (sec Fernebafers) ; melolontha, i. 72 ; fullo, i. 76

Scopoli, i. 106, 109, 111, 115

Scotland, maps of, i. 188

Sea-birds, i. 35

Seal of Gurdon, ii. 191

Sedge-bird (see Willow.wren)

Sedge-warbler, i. 85,106 ; note of, i. 86,94 ; singing at night, i. 145

Selborne Parish, i. 1 ; village, i. 2 ; soil of, i. 2,4 ; streams in, i. 2 ; fossils at, i. 7 ; extent of, i. 12 ; salubrity of, i. 12 ; fall of rain in, i. 12,73 , 275 ; oeeupation of, i. 13 ; population, i. 13 ; situation of, ii. 4 ; in Saxon times, ii. 156 ; valne of the living, ii. 173 ; viear of, befort Domesday Book, ii. 173; Priory, property of, ii. 188,211 ; decay of ii. $229,234,236,243$; rivulet, ii. 239 ; aecount of, ii. 240 ; ruins of, ii. 244 ; importance of, ii. 247

Serpents (see Snakes)

Sex of birds, i. 106

Sexes, distinguishing features of the, i. 107 ; separation of, during winter, i. 117

Shearing sheep, i. 153

Sheep, eloso grazers, i. 20 ; feeding before rain, i. 129 ; of Sussex, i. 152 ; congregating, i. 191 ; in Australia ii. 118 ; foretelling the weather, ii. 119

Shingles on ronf, advantages of, ii. 168 Short-winged birds of passage, i. 33, 40,53

Shrew, water, i. 91 , ii. 72 ; ash. i. 199 ; mouse, i. 199 , ii. 72

Shrikes, i. 63,143 , ii. 55 ; four kind. of, ii. 56

Silkwood, i. 196 ; of spiders, ii. 127: tail, German, i. 38 ; worm, intestines of, used for fishing-taekle, i. 73 , ii. 61

Silver fish, i. 262

Sitta Europaca (sce Nuthatch)

Sknnk, i. 86

Skylark (See lark)

Slugs injurions to wheat, i. 2 I I

Smell, animals reeognised by, i. 153

Smoky atmosphere, cause of, i. $27 \mathrm{j}$

Smother Hies, i. 261, 289

Snails, i. 250 , ii. 141 ; shells eaten by birds, i. 84 , ii. 142,143 ; nutritions food, ii. 142 ; French, ii. 143 
Snakes, (see also Vipers); food of, i. 3 ; feeding once a year, i. 57 ; English, i. 57 ; stink, i. 86 ; tame, i. 86 , ii. 66 ; eating snakes, ii. 49 ; eggs of, ii. 51 ; nest of, ii. 52 ; vertebre of, ii. 53 ; tame, in London, ii. 66

Snipes, i. 32,53 ; in Wolmer Forest, i. 15 ; piping and humming of, i. 32, 53,145 ; make no nest, i. 72 ; sto111acl of, i. 94

Snowflake, i. 48,91 , ii. 44 ; storms, i. 277,281 ; bunting, ii. 44

Sociality of animals, i. 191 ; of dilferent natures, i. 208

Soft-billed birds, migration of, i. 44, 80 ; non-migratory, list of, i. 81

Soil, curious, i. 4 ; good for timber, i. $4,5,25$; inferior for timber, i. 4,25 ; of Wolmer and Ilolt Forests, i. 25 ; chalky and sandy, subject to heat, 1 . 288 ; at Selborne, productive, ii. 10

Solstice, summer and winter, i. 236

Song-bilds, i. $32,80,93,101$; migration of, i. $80,81,117$; non-migratory, i. 81,174 ; niglit, i. 82 ; list of, i. 87 ; loss of voice in, i. 102 ; food of, i. 174

Song of thrush, i. 168, ii. 69 ; of blackbird, i. 168 ; of willow wren, i. 168 ; wood lark, i. 168

Sounds, association of, i. 242

Sow, fecundity of the, i. 207 ; age of, i. 207

Spain, birds migrating to, i. 44

Spaniels, i. 272

Sparrow hawk, i. 167, 252 ; hedge, i. 174 ii. 126 ; flight of, i. 168 ; food of, i. 174 ; egg and nest of the, ii. 126 ; house, i. 103, 169 ; cleaning themselves, i. 112; taking sand-martin's nest, i. 165 ; nidification of, i. 169 ; food of, ii. 85 ; increase of, ii. 85

Sparrows in the City, ii. 84

Speckled diver, i. 82

Spiders, making gossamer webs, i. 190, ii. 127 ; flying, i. 191 ; silk of, ii. 127 Spindle trees, i. 170

Spiracula of fallow deer, i. 45 , ii. 23

Sporting, inherent in mankiud, i. 18, ii. 204 ; dogs, training of, i. 272

Spring-guns, ii, 14

Squirrel, suckled by a cat, i. 209 ; eating nuts, i. 267

Stag, hunt $a$, in Wolmer Forest, i. 16 nostrils of, i.45; bectle, larvæ of, ii.78 Starlings, roosting, ii. 107 ; mode of, catcling, ii. 109 ; food of, ii. 109

Stealing deer, i. 18

Stickleback, i. 35,58 , ii. 54 ; nest of, ii. 55
Stilt plover, i. 247

Stoat, ii. 45

Stocklove (see Wood-pimeon)

Stonechat, i. 113, 144, ii. 117

Stone, free, i. 2, 4,8

Stone curlew, i. $49,50,69,116,273$,

275 ; food of, i. 2,9 ; pote of, i. 65 , 273 ; migration of, i. 65,110 ; makes no nest, i. 72 ; egg of, i. 86 ; flight of, i. 117

Stonebenge, daws breeding at, i. 66 ; how it was built, ii. 59

Stone, sand, i. 8,10 ; rag, i. 9 ; yellow, i. 10; large, found at Selborne, ii. 10 ; coffin lids in Selborne Church, ii. 162

Stones, swallowed by birds, i. 86,94

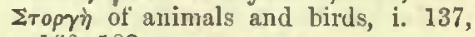
160,183

Storm-cock, i. 144

Strangers elected to Selborne Priory, ii. 218,220

Stratford, Bishop of Winchester, ii. 199

Stubble burning, i. 20

Sulphuring machine for bors, ii. 12

Summer birds of passage, $j .87$; shortwinged, i. 33, 113, 115, 153; list of, i. 53,80 ; soft-billed, i. 120

Sun, red, i. 289

Sunbury-on-Thames, i. 44

Sun dew, round leaved, i. 226

Sundial in White's garden, ii. 7

Superstition of country people, i. 198, ii. 50

Sussex downs, i. 113, 151 ; iron railings from, round St. Paul's Cathedral, ii. 19

Swallows, i. 101, 161, 173, 251 ; young, appearance of, i. 28 ; hatchings of, i. 28 ; hybernation of, i. $28,40,120$, $133,154,156,160,251,269$; driuk flying, i. 37 ; flocks of, i. 40,44 ; 011 the 'llames, i. 40,44 ; late, i. 40,92 , 159 ; migration of, i. $40,74,130$, $140,159,163,184$; congregation of, i. 71,159 ; lute, at Oxford, i. 74; louse, i. $74,155,184$,ii. 14 ; increase of, i. 94 ; and frosts, i. 103,105 ; feeding young on the wing, i. 110, ii. 96 ; and switts, supposed rivalry between, i. 111 ; late, 1. 133 ; food of, i. 142,158 ; lice of, i. 142 ; washing while flying, i. 144, 145, 158 ; carly, i. 155 ; nidification of, $i, 156$; earrs of, i. 157 ; song of, i.158; tail of, i. 160, 167 ; and hawks, i. 181 ; appearance of, i. 184; going under water in win. ter, i. 210 ; appearing in hot weather, i. 211 ; chimner (see Swallow, house) fond of water, i. 269 
INDEX.

Swans, i. 167 ; migration of, i. 121 breeding place at Norwich, ji. 122 ; how to cook, ii. 123

Swedell, birls of i. 173

Swift, Jybernation of, i. 28 ; early migration of, i. 92,181 ; great whitebellied, i. 116,183 ; note of, i. $1 \% 8$ 182 : staying late, i. 131 ; appearance of, i. 144 , ii. 62 ; or black martin, i. 177 ; nidification of, i. 177, 178 propagation of, i. 178 ; food of, $i$ $179,180,183$; and hawks i. 180 young of, i. 180,183 ; colonr of, i. 181 ; flens ol; i. 182, 258 ; feet of, i. 182 ; in london, i. 183 ; sinilar to vuekoo in formation, i. 204 ; pairing every year in same number, i. 222 ; late breeding, i. 258 ; late departurt of, i. 258

Swifts, i. 36,92

Sylvia loquax, lesser willow wren, i. 61 ; trochilas larger willow wren, i. 61 ; sibilatrix smallest willow wren, i. 61 ; curruca lesser white throat, i. 269

\section{$\mathrm{T}$.}

Tadpoles, i. 55

Tails, of woodpecker, i. 229 , ii. 90 rat, ii. 36 ; horse, long, ii. 125

Tameness, natural, of birds, i. 89,135

Taming of animals, \&c., i. 68 , ii. 59

Tanners' Wood, ii. 238

Tanyard at Selborne Priory, ii. 238

Teals, i. 23, 36, 140, 145

Teeth of rabbits, ii. 25

Teneh, i. 22

Tenderuess, natural, of birds, i. 89,135

Tender slurulus, how planted, i. 298

"Tenpenny uails in the walls," i. 10, ii. 9

Thames, frozen over, i. 283 ; curiosities found in the, ii 20

Thaws, i. 283; caused by underground vapours, i. 279

Thermometers, nse of, i. 256

'I'hrusls, the, i. 49 , ii. 69 ; food of, $i$ 49,185 ; breeding of, i. 76 ; nidification of, i. 186 ; killed by frost, i. 278. 284 ; egg of, ii. 68

Thrush, Missel, i. 38,90 , ii. $60^{\circ}$; fiereeness of, 1. 185 ; fight with a magnie, i. 185,186 ; food of, i. 186 ; egg of ii. 69 ; nest of, made with paper, ii. 70

Thunderstorms, rarity of, at Selborne, i. 290

Tiles first used for roofs, ii. 23i

Timber, good soi] for, i. 4 ; in Holt Forest, i. 20

VOL. II.
Tipula (Long-legs), i. 210

Titlark, or tree-pipit, i. 93,113 , ii. 74 ; feeding in wiuter, i. 33 ; singing, i. 144 ; at night, i. 94

Titmouse, song of, i. 170 ; great, i 170 ; fool of, i. 175 ; bill of, i. 175 ; hlue, i. 176 ; great blackheaded, i. 176: long-tailed, i. 176 ; marsh, i. 176 ; pulling straws from eaves, $i$. 176,278

Toads, breeding of, i. 54 ; venom of $i$ 54 ; tame, i. 54,68 ; man swallowing a, i. 59 ; as a cure for caneer, i. 59 , 66 , ii. 50

Tombs, i. 21 ; in Selbome church, ii $161,160^{\circ}$

Tongue of woodpecker, ii. 9

I'oothwort, i. 226

'lortoise, land, i. 113, 137, 249, ii. 6 ; hyberuation of, i. 113, 137, 155, 211, 249 ; food of, i. 114; age of, i. 114 feeding before rain, i. 137 ; instinet of, i. 250 ; tenacity of life in the, $i$. 251 ; structure of, ii. 110,111

Travelling mountains, i. 237

'l'ree beetles, i. 123

Trees and forests, effect of, on rainfall, i. 200, ii. 132; perfect alembics, i. 200 ; killed by Irost, i. 280, 285, 286 ; in churchyarls, ii. 72

Trenehes, ancient, at Selborne, ii. 259

Tringa hypoleneus (see Sandpiper), i. 62

Trout, i. 35 ; breeding at Selborne, ii. 14

Truftles, i. 227

Tumuli at Selborne, ii. 257

Trumbridge, ii. 239

Turdus torquatus (sec Ring ouzel) ; pilaris (see Hicldfare)

Turkey, gizzard of, power of, ii. 66

Turnip fly, i. 125

Tusk of elephant, growth of, and injuries to, ii. 26

Tustan, or St. John's wort, ii. 18

V.

Vuccinizm oxycoccos (cranberry); myrtillus (bilberry), i. 226

Vase found at Selborne Priory, ii. 244 ;

Chapel field, ii. 253, 254

Verdure of trees, late, i. 123

Vespertilio muerinus (bat), i. 36 ; utu. rilus, (long-eared bat), i. 36 ; altivlans (large bat), i. 129

Veretable caterpillar of New Zealand, ii. 143

Vegetables as a diet, i. 21 j

Vegetation, i. 224

Veuison, varicties of, ii. 23 
Vine, diseases of, i. 259 ; parasite of the, i. 259

Vicarage at Selborne, ii. 168

Vicar's of Selborne, list of, ii. 173

Vinago (cow pigeon), i. 253

Vinca minor (lesser periwinkle), i. 226

Vipers, breeding, i. 54, 57, 205; oil as remedy for poison of, i. 57 ; eggs of, i. 57 ; food of, i. 57 , ii. 135 ; in the water, i. 57 ; swallowing their young, i. 57, 205, ii. 133 ; young of, i. 205 ; peacocks kill, ii. 107; skin of, ii. 135 ; poison of, ii, 136 ; how to catch, ii. 138

Virgil's description of stubble burning, i. 20 ; bees, i. 145,219 ; swallows, i. 156 , ii. 119

Visitation ol Bishop of Winchester, ii. 202

Visitatio Notabilis, the, ii. 202

Vitrified stone, i. 8

Volcano in Norway, i. 289

Vultures, i. 120, 292 ; and dogs associating, i. 292

W.

Wagtrils, white, i. $42,144,174$, ii. 45; motion of tail of, i. 168; food of, i. 174 ; pied, ii. 45 ; four kinds, ii. 45 ; grey, ii. 45 ; note of, ii. 45 ; pugnacity of, ii. 45 ; yellow, ii. 45

Waldon lodge, i. 21

Waltham blacks, i. 16,18 , ii. 2

Walwort, i. 227

War between England and France, ii. 190

Warbler, grasshopper; sedge (see Willow wreu)

Warrens at Selborne, ii. 226

Wasps, i. 287 ; nests, i. 33

Water, hard and soft, i. 3

Water-fowl, i. 23 ; rat, i. 32,91 ; snake, i. 37 ; ouzel, i. 112

Water at Selbor'ue, i. 3

Water-onzel, i. 112, ii. 95 ; food of, ii. 96

Water, cattle frequenting, i. 32 ; efts, i. 55,60 ; snake, i. 57 ; efts spawn in, i. 60 ; fowl, wings and feet of, i. 83 ; rat, i. 91 ; shrew mouse, i. 91 , ii. 72 ; hybernation of, i. 92 ; distilled from trees, i. 100 ; condensed by fogs, \&c., i. 202 ; scarcity of, ii. 11 ; wheel, anl. cient, ii. 14 ; "bones," ii. 20 ; weed, American, ii. 30 ; vole, ii. 34 ; rat, white, ii. 35 ; reservoir, ii. 193 ; pipes at Selborne aueient, ii. 237

Waxwing (see Silk-tail)

Waynflete, William of, Bishop of Winchester, ii. 215
Weapons, ancient, found at Selborne, ii. 254,261

Weasel, i. $43,47,167$, ii. 45

Weather, the, i. 103, 102, 186, 189, 211 ,

$238,277,289$, ii. 153 ; influenciner migration of birds, i. 118, 128; at Plymoutll, i. 275

Veavers downs, i. 10

Wert-head, i. 2, ii. 14, 157

Well, lizard found in, $i$. 64

Wells, denth of, i. 3, ii. 10

Wey river, the, i. 3, 27

Wharldon Chapel, ii. 238

Wheatear, i. $42,113,144,154$, ii. 45 ;

food of, i. 176 ; does not always migrate, i. 43 ; migration of, ii. 45

Wheat crops, i. 162 ; bread, use of, i. 215

Whetham hills, i. 257

Whiuchat, i. 113, 144, 155, ii. 118 ; food of, i. 176

White malm, i. 4 ; rooks, i. 47 , ii. 46 ; larks, i. 48,91 ; lares, i. 91 ; starlings, ii. $46^{\circ}$

White owls, increase of, ii. 65

White, Gilbert, birth of, ii. 3 ; prominent events in the life of, ii. 3 ; honse of, ii. 5, 8 ; curate of Farring. don, ii. 9 ; tomb of, ii. 9 ; restores Selborwe Church, ii. 175

Whitethroat, i. 101, 103, 154, 171, ii. 83 ; lesser, i. 269 , ii. 84 ; note of, i. 171,269 ; food of, i. 172 ; nest and eggs of, ii. 83

Widgeon, i. 23, 36

Wilherforce, Bishop of Winchester, ii. 15

Whortle, or bilberry, i. 226

Wild boars, in Wolmer Forest, i. 26 ; Captain Salonis, ii. 32 ; in Ingland, ii. 33 ; fowls, i. 35,140 ; geese, breeding of i. 91 ducks, i. 40,143 , ii 13

Willow-lark, i. $51,61,76,85$; three kinds of, i. $51,61,76,85$; eating fruit, i. 53 ; note of, i. $86,94,145$; sagacity of, i. 139

Willow-wren, i. $49,51,52,85,103$, 106,269

Willoughby, Mr., i. 44

Winchester Cathedral rebuilt, ii. 159

Windhover (see Kestrel)

Windsor Forest, trees in, ii. 18

Wings of birds loollow, i. 229 ; placed too forward, i. 230 ; backwari, i. 230

Winter birds of passage, list of, i. 81,87

Witches, i. 198

Wolmer Folest, i. 4, 14, ii. 19, 28, 188 ; stone found in, i. 10 ; fossils found in, i. 14: wild-fowl in, i, 15 ; game in, i. 15, 16 ; Queen Amne in, i. 16; 
limits of, i. 21 ; searcity ol trees ju, i. 22 ; leased by the crown, i. 25 ; soil of, i. 25 ; bonrs and buffiloes in, i. 26 ; derivation of name, ii. 51, when formed, ii. 157 ; Sir A. Gurdon, custos of, ii. 188

Wolmer Lake, i. 15, 22, ii. 12, 252 size of, i. 33 ; eoins found in, i. 24

Wolvenere (sce Wolmer lake)

Wolves in Ilanpshire, ii. 31, 153; Scotland and Wales, ii. 31

Woodborers, ii. 14

Woodeocks, i. 12, ii. 96 ; stomach of, i. 94 ; earryin their young, i. 110 ii. 96 ; migration of, i. 122 , ii. 110 breeding in England, i. 118 ; in Austria, i. 119 ; migration at night, i. 121 ; occasional sluggishness of, i. 122,129 ; food of, ii. 96

Woodpecker, s] otted, i. 53 ; flight of, i. 244; inlatomy of, li. 89

Woodpigeoll, i. 123, 253, 25t; migra tion of, i. $123,144,255$; wild, i. 253 ; food of, i. 255

Wood, fossil, i. 14; lark, i. 101, ii. \$3 song of, i. 168 ; eggs and nest of, ii. 53

Worms, eartl, i. 210 ; use of, i. 210 ; lermaphrodites, i. 211; blind (sec Blind worm)

Wourali poisols, ii. 1 to
Wren, i. 93, 101, ii. 81; golden-cresteel, i. $36,53,62,174$; tameness of, i. 84 song of, i. 170; fond of, i. 174 ; wilJow, ii. 48 ; woud, ii. 48,49 ; earers of, ii. 49 ; 1 est of, ii. 49,81 ; nest of, built between two stoats, ii. 82

Wryeek, i. $17 t$, ii. 126 ; egg :ml nest of, ii. 126

Wych elms, i. 5 , ii. 17 ; lazel, i. :5

Wykeham, Willian of, i. 163 ; rebuileling Winchester Cathedral, ii. 159 Bisliop of Wincliester, visitation of, ii. 201 ; elaracter of, ii. 208

Wynchester, Johu, elected as Prinr, ii. 209

\section{Y.}

Yollow-laammer, i. 93, ii. 74; song of, i. 101, ii. 74

Yellow wort, i. 226

Yew tree, birds feeding on, i. 35 ; nuscient, in Selborne Churchyard, ii. \$, 170 ; berries fatal to auimals, ii. 41 , 170 ; leaves of, very injurious to cattle, ii. 41 ; difference between tuales and females, ii. 170 ; not injurions to sheep and turkeys, ii. 171

\section{$\%$}

Zig-zag, the, ii. 10

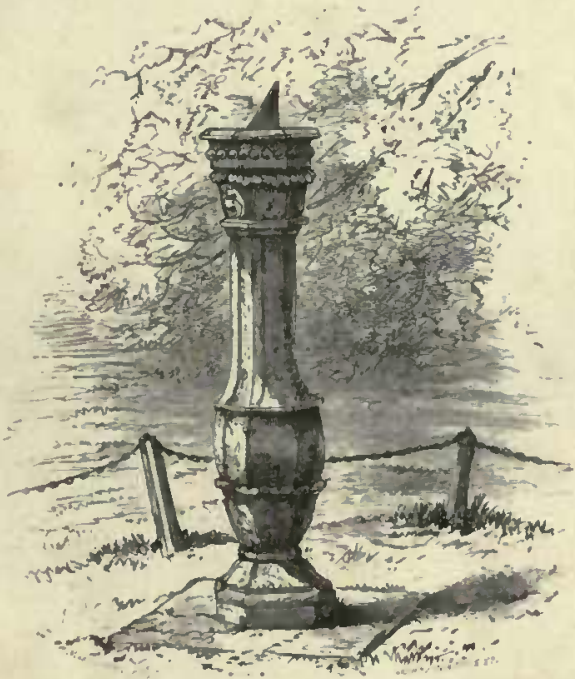

SUS-DIAL IN GIIRFRT WIITE'S GARIKW. 

THIS BOOK IS DUE ON THE LAST DATE STAMPED BELOW

AN INITIAL FINE OF 25 CENTS WILL BE ASSESSED FOR FAILURE TO RETURN THIS BOOK ON THE DATE DUE. THE PENALTY WILL INCREASE TO 50 CENTS ON THE FOURTH DAY AND TO \$1.00 ON THE SEVENTH DAY OVERDUE.

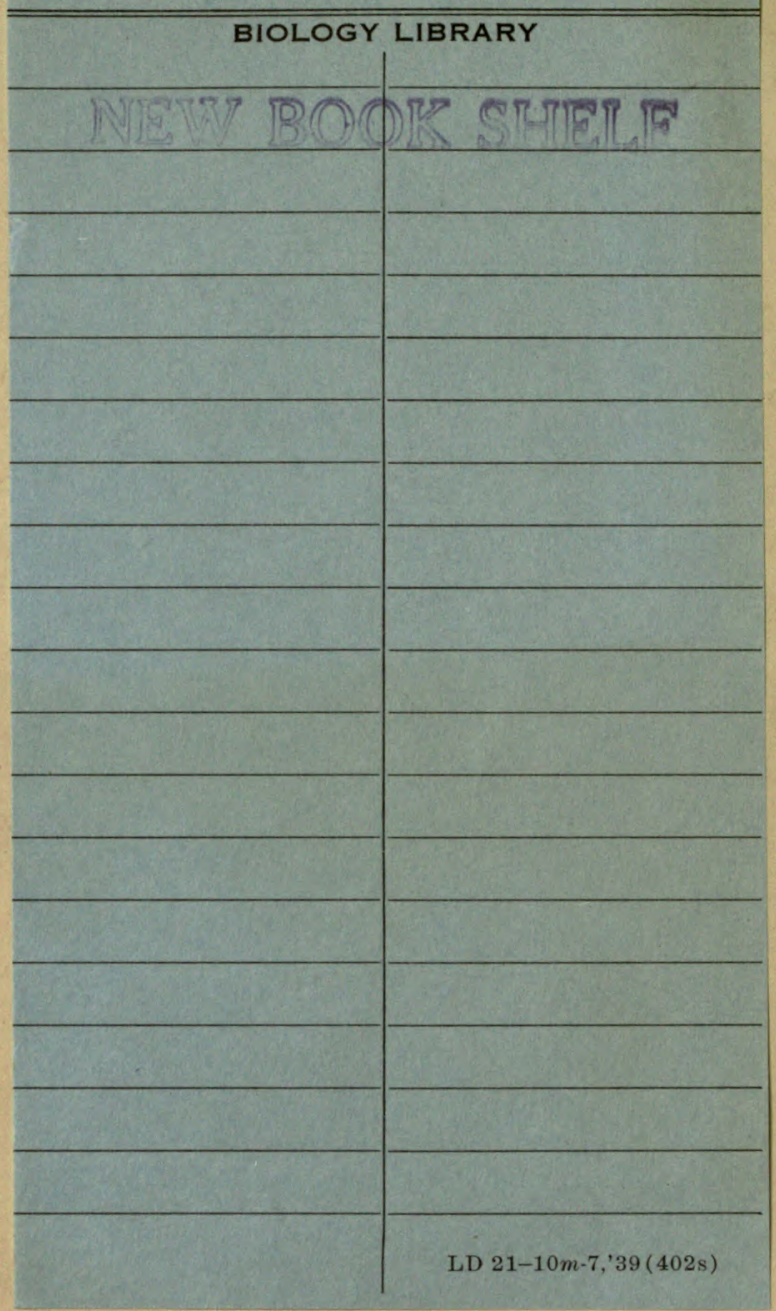


(2)

(c)

(e) 